Sandra Maret Scovenna

\title{
NAS LINHAS E ENTRELINHAS DO RISO: As crônicas humorísticas de Belmonte (1932-1935)
}

Dissertação de Mestrado em História Social apresentada à Faculdade de Filosofia, Letras e Ciências Humanas da Universidade de São Paulo, sob a orientação do Prof. Dr. Marcos Silva. 
Sandra Maret Scovenna

\title{
NAS LINHAS E ENTRELINHAS DO RISO: As crônicas humorísticas de Belmonte (1932-1935)
}

\author{
BANCA
}

São Paulo 


\section{Agradecimentos}

Para a elaboração desta dissertação, recebi a ajuda e o apoio de muitas pessoas especiais.

Primeiramente, destaco o apoio oferecido por minha família. Aos meus pais, Vlasta Maret Scovenna e Horacio Angel Scovenna, agradeço de coração pelo suporte afetivo e financeiro, imprescindíveis. Eles sempre me incentivaram a prosseguir os estudos, e meu pai, talentoso contador de histórias, me despertou o interesse pela narrativa e pela História. Sou grata também ao apoio de meus tios maternos, Frantisek Maret e Cléia Ferreira Maret. Aos meus primos, Renata Ester Maret, Ivanov Cárdenas e ao pequeno Ivan; aos primos Francisco André Maret, Priscila Miwa e ao pequeno Gustavo. Ivan e Gustavo encantam meus finais de semana com sua alegria infantil e suas traquinagens. À dona Lúcia Stepan, minha vovó adotiva. A Luzinete Ribeiro, que muito me acudiu na organização e arrumação da casa.

Aos amigos da família de décadas e que tanto nos auxiliaram durante a doença de meu pai, há alguns anos: Franco, Neide e Liana.

Meu muito obrigado aos tios paternos que vivem na Argentina e que, mesmo a distância, torceram por mim: minha querida tia Juana e meus tios Carlos, Ricardo, Suzana, Lala e Augusto.

Agradeço especialmente a minha avó materna, Katerina Maret (in memoriam), por ter tido a paciência de me narrar, repetidamente durante minha infância, as suas peripécias e as de seu marido (Fratisek Maret) para sobreviverem durante a Segunda Guerra Mundial em uma Tchecoslováquia ocupada pelo Nazismo. Desde meus quatro ou cinco anos, os contos dos Irmãos Grimm foram substituídos pelas palavras Nazismo, Hitler, Rússia, União Soviética, Stálin, e por narrativas que englobavam o bombardeio de cidades, familiares e amigos mortos ou mutilados, campo de concentração e (por fim) a fuga atribulada e desesperada dos Maret de uma Europa arrasada pela intolerância, para qualquer destino. Em uma fria manhã de agosto, o primeiro navio que partiu daquele porto italiano e no qual minha família materna embarcou, tinha como destino um país misterioso para aquela gente: Rio de Janeiro - Brasil.

Agradeço ao meu orientador, Professor Marcos Silva, essencial para a elaboração dessa dissertação. Obrigada pelo apoio e pela paciência. Marcos se revelou, mais do que orientador, um amigo.

Ao CNPq - Conselho Nacional de Desenvolvimento Científico e Tecnológico - sou grata pela bolsa de pesquisa concedida a partir de novembro de 2008. Sem esse precioso auxílio, a elaboração desta dissertação teria sido muito mais difícil. À Universidade de São Paulo e às Universidades Públicas, essenciais para o desenvolvimento da pesquisa brasileira. 
Sou muito grata aos Professores Maria Lígia Prado e Gilberto Maringoni, que participaram da minha Banca e me ajudaram bastante com suas instigantes e preciosas ponderações.

Agradeço à Professora Maria Luiza Tucci Carneiro pelo contínuo apoio e pelas reflexões acerca do racismo e da intolerância, tendo como objetivo, sempre, o respeito à diversidade humana. À Professora Raquel Glezer, pelas excelentes aulas sobre a História e a Historiografia de São Paulo nos séculos XIX e XX. Ao Professor Jaime Ginzburg, do Departamento de Letras, cujas interessantes aulas me ajudaram a refletir sobre a Literatura Brasileira, o gênero crônica, autoritarismo, psicanálise, ironia e melancolia. Todos vocês me auxiliaram muito na caminhada.

Sou grata aos funcionários do setor de consulta do Arquivo do Estado de São Paulo, em especial ao Tárcio Nascimento Silva, pela paciência. E também aos rapazes do banco de dados do Arquivo da Folha de São Paulo, Edmir e Luís. Obrigada pelo auxílio e pela atenção de todos vocês.

À pesquisadora Andréa de Araújo Nogueira, agradeço pelo encontro em um sábado de maio ensolarado para falarmos exclusivamente sobre Belmonte e nossas pesquisas.

Ao cineasta Ivo Branco, diretor do premiado curta-metragem Belmonte, agradeço pelo filme gentilmente cedido e pela longa entrevista, que culminou na elaboração de minha comunicação para a ANPUH de 2009, Belmonte, um documentário.

Todavia, esses agradecimentos resultariam incompletos sem os amigos, companheiros dessa longa jornada. E são muitos.

Agradeço ao apoio dos amigos que deixei nas escolas nas quais lecionei - no PROMAC de São Bernardo do Campo, sou grata a Maria do Socorro Paiva, Marta Nardy, Silvana Moreira Palomares, Maria Tereza Maldonado, Maria Escudeiro, Elizete Severino, Suely e Daniel Perez. Muito aprendi com os alunos das EMEFS José Ibiapino Franklim e José Luís Jucá, e pelos quais guardo muito carinho. Na Escola Estadual João Ramalho, é impossível esquecer-me das seguintes pessoas: Isabel, Maria Regina, Maura, Maria do Céu, Meire, Valter, Ana Maria, Rubens, Carlinhos, Juliana, Marcos, Franciele, Marisol e Mara.

Meu agradecimento especial a Solange Rossignoli e Marcos Rocha (Marbé), artistas plásticos que me impediram de abandonar definitivamente o desenho e a pintura. À Ilva Aceto Maranesi (in memoriam) que, durante minha adolescência, consolidou meu interesse pela arte.

Ao meu velho e grande amigo Jean Carlo Mogge Canesqui, de quem gosto muito, e com quem aprendi a apreciar ainda mais a sétima arte. A Luciana Lima, querida amiga desde a adolescência, assim como Kênia Cristiane da Silva.

A Sylvia Tamie Anan, agradeço pelos filmes bacanas que vimos e pelas interessantes e instigantes conversas que versavam sobre Literatura, Teoria Literária e História. Sou grata também a Cecília Campos França e ao Gerson, pelos bons papos. 
Sou grata à Mirian Sancore de Oliveira Senra, Maria Sancore Senra e ao Frank Floriano de Moraes. Mirian, gentilmente, fez a correção gramatical do meu relatório de qualificação. Maria coloriu muitos de meus finais de semana com atenção e deliciosos almoços. E Frank, com seu bom humor, me descontraiu inúmeras vezes.

Aos queridos amigos da Universidade, Osmar Souza, Igor Nóboa, Beatriz Pan Chacon, Ricardo Sequeira Bechelli, Bertholdo Maurício da Costa, Lúcia Silva Parra, Márcia Takeuchi e Ana Lúcia Del Vecchio. Aos amigos que, à época da graduação, perfaziam comigo, quase que diariamente, o caminho São Bernardo do Campo-USP e USP-São Bernardo do Campo: João Guazzelli (in memoriam), Vanessa Molnar, Simone Coutinho, Breno Sebastiani, Juliana de Paula Silva, Rodolfo Jacobini e Cláudio Gonçalves de Oliveira. Ainda que atualmente estejamos afastados uns dos outros na maior parte do tempo, pois cada um seguiu seu caminho, vocês são absolutamente inesquecíveis.

E sou grata, sobretudo, a Marcos Sancore Senra, meu amor, meu companheiro. 


\section{$\underline{\text { Resumo }}$}

O objetivo da presente dissertação de mestrado é propor uma análise de parte das crônicas humorísticas de Benedito Bastos Barreto, o Belmonte. A análise desta produção literária, escrita entre 1932 e 1935, tem como eixo as temáticas mais constantes na escrita de Belmonte: a rejeição do governo de Getúlio Vargas e do Nazi-fascismo e as severas críticas à modernidade técnica.

Em suas críticas ao Nazi-fascismo, elaboradas na primeira metade da década de trinta do século passado, o cronista demonstrou precocidade e ineditismo frente aos jornalistas e jornais paulistas da época, sendo que estes tendiam a se calar ou a demonstrar simpatia perante a ascensão dos governos Fascistas de Hitler e Mussolini.

E, ao elaborar críticas à modernidade técnica, sugerimos que Belmonte não apenas repudiava o incrível potencial bélico - demonstrado com ineditismo na Primeira Guerra Mundial -, como também apontava para a complexa e problemática modernização da cidade de São Paulo, assim como a aspectos atribulados da sua história recente.

\section{Palavras-chave:}

Belmonte (Benedito Bastos Barreto), Crônica, Humor, Folha da Noite, São Paulo nos anos 30.

\section{$\underline{\text { Abstract }}$}

The purpose of the present dissertation is to propose an analysis of some humoristic chronicles of Benedito Bastos Barreto, the Belmonte. The analysis of this literary work, written between 1932 and 1935, has the most often thematics on Belmonte's writing as main point: the rejection of Getúlios Vargas' government and of the Nazi-fascism, as well as the severe critics to the technical modernity.

In his critics against the Nazi-fascism, elaborated during the first half of the thirties of the last century, the chronist demonstrates to be precoce and unheard of when compared to the jornalists and the newspapers of his time, for those used to keep quiet or demonstrate appreciation for the rising of Hitler's and Mussolini's fascist governments.

And, as he elaborates critics to the techincal modernity, we sugest that Belmonte did not just repudiate the amazing warlike potencial - that was demonstrated for the first time on the First World War -, as well as he also indicates the complex and problematic modernization of São Paulo city, and the troubled aspects of its recent history. 


\section{Key words:}

Belmonte (Benedito Bastos Barreto), Chronicle, Humour, Folha da Noite, São Paulo in the thirties. 


\section{Sumário}

$\begin{array}{ll}\text { Introdução } & 08\end{array}$

1. Capítulo: As Folhas, as Crônicas e seus Leitores 19

1.1. Panorama Geral da Imprensa Liberal Paulista 19

1.2. Biografia de Belmonte 34

2. Capítulo: 1930-1934: Impressões sobre o "Novo” 44

2.1. Sobre o Humor $\quad 50$

2.2. Ironia e Melancolia $\quad 73$

3. Capítulo: O Antifascismo de Belmonte 92

3.1. Os Jornais e o Nazi-fascismo 94

3.2. Nas Linhas e Entrelinhas das Crônicas 98

4. Capítulo: Os (Des)caminhos da Modernidade 163

4.1. O Mal-estar na Modernidade 165

4.2. Uma Modernidade Paradoxal 170

$\begin{array}{ll}\text { Algumas Conclusões e Perspectivas } & 207\end{array}$

$\begin{array}{lr}\text { Acervos e Bibliotecas } & 210\end{array}$

$\begin{array}{ll}\text { Fontes } & 211\end{array}$

$\begin{array}{ll}\text { Bibliografia } & 224\end{array}$ 


\section{$\underline{\text { Introdução }}$}

A presente dissertação de mestrado tem por objetivo analisar uma pequena parte da extensa obra artística de Benedito Bastos Barreto, o Belmonte (1896-1947), jornalista, chargista e cronista que trabalhou para a imprensa paulista de 1914 a 1947.

Belmonte fez carreira nos periódicos da Empresa Folha da Manhã ${ }^{1}$. De 1921 a 1925, ele colaborou com o jornal Folha da Noite. Desta data até 1927, publicou seus trabalhos de crônicas e charges na Folha da Manhã e, de 1931 a 1947, contribuiu ininterruptamente com a Folha da Noite, ainda que, esporadicamente, suas charges e crônicas fossem impressas também na Folha da Manhã.

Dado o volume da produção artística de Belmonte na Folha, que é impressionante - afinal, são charges, caricaturas e crônicas elaboradas em mais de 25 anos de trabalho -, tivemos que optar por um recorte cronológico modesto. Nesse sentido, nossas fontes principais são as crônicas compreendidas entre outubro de 1932 e abril de 1935, publicadas quase que diariamente na Folha da Noite $^{2}$. Em 1935, algumas delas foram selecionadas, provavelmente pelo autor, para a impressão em formato de livro pela Editora José Olympio, de grande prestígio naquele período.

As crônicas de Belmonte são, em sua grande maioria, humorísticas, e o livro publicado em 1935 recebeu o nome de Idéas de João Ninguém. Ele tem 59 crônicas, dois contos e 11 ilustrações de sua autoria. Este livro de Belmonte se prestou para, de início, delimitar as balizas cronológicas de nossa pesquisa, uma vez que, na sua introdução, o artista esclarece que as crônicas foram selecionadas dentre toda a sua produção textual realizada em 1933 e 1934 na Folha da Noite $e^{3}$. Mas observamos que ele também escolheu para compor Idéas de João Ninguém crônicas de janeiro de 1935.

No princípio do desenvolvimento dessa pesquisa, tínhamos como fonte o livro Idéas de João Ninguém. Entretanto, ao coletarmos no acervo de jornais do Arquivo do Estado de São Paulo as crônicas em comum aos periódicos e ao livro, deparamo-nos com um material mais amplo, extenso e rico.

\footnotetext{
${ }^{1}$ Essa empresa jornalística passou a ser nomeada dessa forma a partir de 20 de janeiro de 1931. Anteriormente, à época da direção de Olival Costa e Pedro Cunha, ela era a "Folha" e, de 1925 à 1930, as "Folhas". Cf. Carlos Guilherme da Mota e Maria Helena Capelato. História da Folha de São Paulo (1921-1981). São Paulo: IMPRES, 1980, pp. III-VIII e pp. 13-14.

${ }^{2}$ Destinava-se uma crônica por dia para o jornal. Durante as décadas de 1930 e 40, a produção escrita e chargística de Belmonte era sempre publicada na vespertina Folha da Noite, sendo, eventualmente, reimpressa no dia seguinte, na Folha da Manhã.

3 "ESTE LIVRO... é, como o que dei á publicidade anteriormente, a collecção de algumas das chronicas (...) publicadas na 'Folha da Noite', em 1933 e 1934.” Apud BELMONTE. Idéas de João Ninguém. Rio de Janeiro: José Olympio, 1935, p.05.
} 
A investigação sobre o jornal permitiu-nos conhecer e refletir mais sobre o trabalho literário de Belmonte. O seu antifascismo é um grande exemplo: se no livro há apenas duas crônicas antifascistas, nos números da Folha da Noite encontramos uma quantidade acentuadamente maior. Logo, se nos concentrássemos apenas no livro, esta possibilidade de análise histórica sobre a fascinante temática do artista paulistano resultaria empobrecida, se não impossibilitada por completo, na pior das hipóteses.

A escolha que recaiu sobre o primeiro semestre de 1935 como a data-limite final da pesquisa para esta dissertação coincidiu também com o advento da repressora Lei de Segurança Nacional. Sua discussão, elaboração e aprovação, ocorridas entre janeiro e 04 de abril do referido ano, refletem-se nos trabalhos de Belmonte, que se tornaram mais cautelosos, voltados principalmente para o dia-a-dia da capital de São Paulo e para acontecimentos engraçados, curiosos ou pouco críveis publicados na Folha da Noite, e ausentes de uma conotação política mais direta.

Ainda que, daqueles dois anos, Belmonte tenha selecionado apenas uma pequena parte da sua intensa produção escrita para compor o livro Idéas de João Ninguém, abrangemos em nossa pesquisa todas as crônicas publicadas na Folha da Noite durante o período, pois almejamos ter uma compreensão geral, mais vasta e aprofundada da obra deste artista. Afinal, ele escolheu para o livro 59 crônicas, sendo que toda a sua produção literária para o jornal, de outubro de 1932 a abril de 1935, alcançou 370 crônicas.

Mas a data-limite inicial de nossa pesquisa ainda não estava bem definida, se deveria acompanhar a proposta de seleção do livro Idéas de João Ninguém, ou seja, a partir de janeiro de 1933. Optamos finalmente por fixá-la em outubro de 1932, tendo em vista que a amargura advinda da Revolução paulista fracassada em 1932 é recorrente nas crônicas do artista. Nesse sentido, se seguíssemos rigidamente a seleção temporal do livro, concorreríamos para uma exclusão arbitrária e inexplicável de fontes. Portanto, nossa análise compreende as crônicas publicadas de outubro de 1932 a abril de 1935, no jornal Folha da Noite.

É impossível olvidar-se de Belmonte quando o assunto é história e imprensa, a menos que se queira cometer uma injustiça. Trabalhando diariamente por mais de duas décadas na Folha da Noite e, com menor intensidade, na Folha da Manha $\tilde{a}^{4}$, Belmonte foi eficiente chargista, caricaturista e excelente cronista. Além do livro de crônicas Idéas de João Ninguém, o artista publicara, no ano de 1933, Assim falou Juca Pato ${ }^{5}$. Também foram lançadas coletâneas de suas charges e caricaturas:

\footnotetext{
${ }^{4}$ As Folhas tiveram uma longa permanência no meio jornalístico, sendo publicadas até 1960, quando unidas para formação da Folha de São Paulo,e significativa participação na vida política do estado de São Paulo e do país. Ver Maria Helena Capelato. Os Arautos do Liberalismo. Imprensa Paulista (1920-1945). São Paulo: Brasiliense, 1989, pp. 25-28.

${ }^{5}$ BELMONTE. Assim falou Juca Pato (aspectos divertidos de uma confusão dramática). São Paulo: Companhia Editora Nacional, 1933.
} 
Angústias do Juca Pato ${ }^{6}$, No Reino da Confusão, Música, Maestro!, A Guerra do Juca e Caricatura dos Tempos ${ }^{7}$.

A Editora Melhoramentos lançou, em 1944, um livro de Belmonte intitulado Brasil de Outrora, no qual sobressaem os belos desenhos inspirados nas gravuras de Johann Moritz Rugendas (1802-1858). Belmonte publicou ainda No Tempo dos Bandeirantes ${ }^{8}$. Esse ensaio histórico revelanos um árduo trabalho de pesquisa e uma profunda riqueza de detalhes na descrição do cotidiano dos moradores da São Paulo de antanho ${ }^{9}$.

Em 1925, Belmonte criou para a Folha da Manhã aquele que tornaria famoso o seu trabalho de desenhista humorístico: o Juca Pato, personagem constantemente presente em suas charges até 1947. O Juca era magro, de aspecto frágil, baixo e careca (“de tanto levar na cabeça”). O personagem morava em São Paulo e sofria com os desmandos e a incompetência dos governos federal, estadual e municipal; além do mais, ele vivia esgotado por causa da exploração dos grandes monopólios estrangeiros que dominavam os serviços públicos da sua cidade. Juca era marcadamente queixoso e mal-humorado, como se carregasse toda a sociedade brasileira em suas costas.

Houve um amplo processo de popularização desse personagem amargurado e crítico ${ }^{10}$, pois os problemas do Juca eram costumeiramente sofridos por parte considerável das camadas médias: o transporte público de má qualidade, a carestia, os altos impostos, as ruas esburacadas...

\footnotetext{
${ }^{6}$ BELMONTE. Angústias do Juca Pato. São Paulo: Casa Editora Rochêa, 1926.

${ }^{7}$ BELMONTE. No Reino da Confusão. São Paulo: Edição da Folha da Manhã, 1939; Música, Maestro! São Paulo: Edição da Folha da Manhã, 1940; A Guerra do Juca. São Paulo: Edição do Autor, 1941 e Caricatura dos Tempos. São Paulo: Edições Melhoramentos, 1948.

${ }^{8}$ BELMONTE. No tempo dos Bandeirantes. São Paulo: Departamento de Cultura da Prefeitura Municipal de São Paulo, 1939.

9 As qualidades da obra de Belmonte foram sublinhadas por Nélson Werneck Sodré: “...Belmonte, Benedito Bastos Barreto, procedeu a um levantamento dos costumes paulistas dos três primeiros séculos com um rigor, uma exatidão, uma riqueza informativa que nenhum compêndio substitui. É toda a vida dos bandeirantes, seus hábitos, suas crenças, suas maneiras de encarar a vida, a administração, a coisa pública, a coisa privada, além dos objetos, as armas, os utensílios, as vestes, os ornamentos, a casa, o que comia, como fazia fogo, que Belmonte apresenta, despretensiosamente.” Ver em Nélson Werneck Sodré. O que se deve ler para conhecer o Brasil. Rio de Janeiro: Centro Brasileiro de Pesquisas Educacionais e Ministério da Educação e Cultura, 1960, p.72.

${ }^{10}$ Entre as décadas de 20 e 40, o Juca deu nome a marcas de cigarro, refrescos, bares e restaurantes. Ver Andréa de Araújo Nogueira. Um Juca na Cidade: representatividade do personagem criado por Belmonte na imprensa paulista (Folha da Manhã 1925-1927). São Paulo: IA-Unesp, 1999, pp. 91-94. (Dissertação de Mestrado)
} 


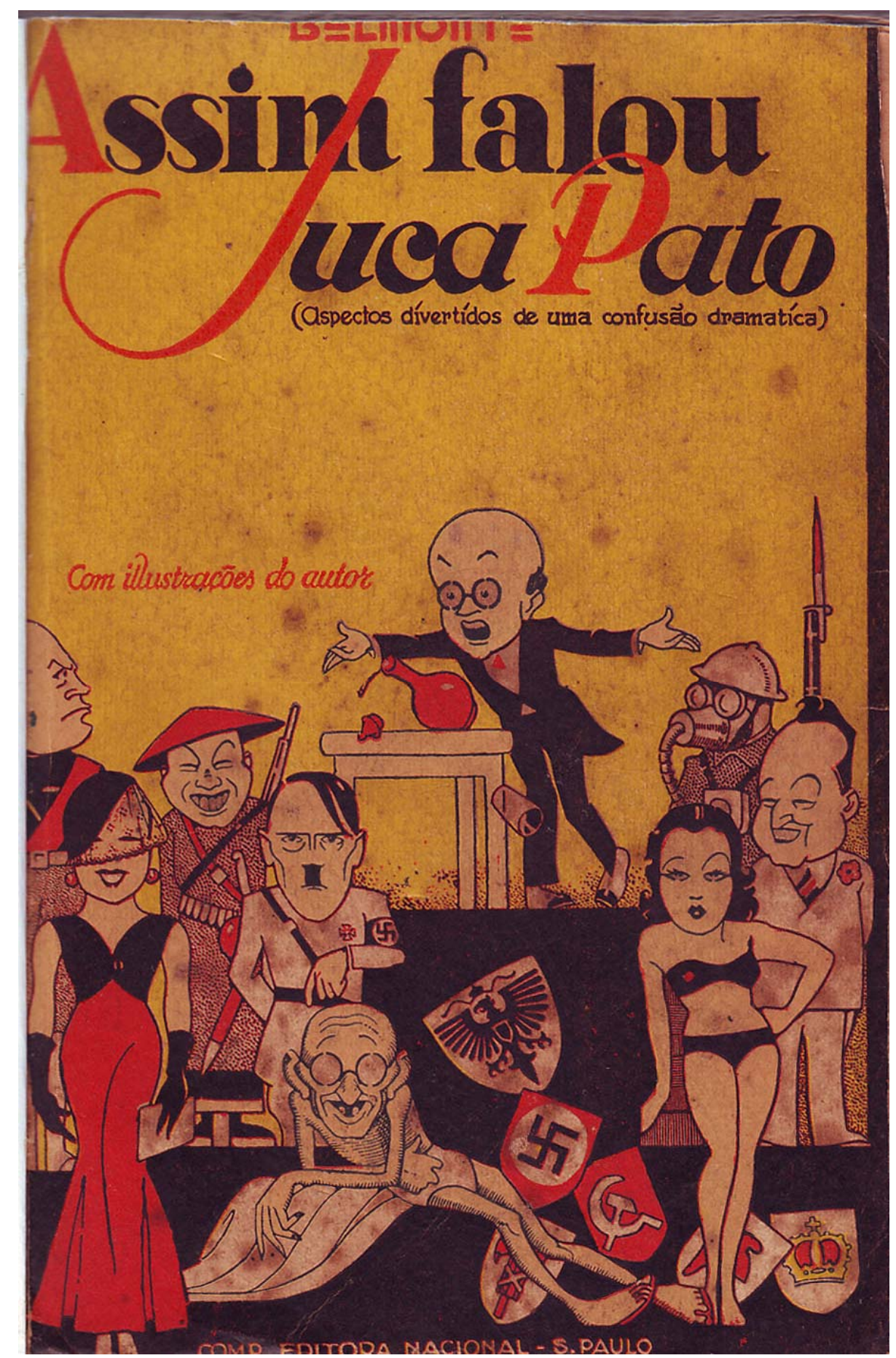

Fig. 1. Juca Pato tenta discursar na tribuna.

Capa do livro

Assim falou Juca Pato. BELMONTE.

Acervo da autora. 
Todavia, durante o Estado Novo, o Juca Pato apareceu menos freqüentemente, conseqüência provável do receio de Belmonte de desagradar às temíveis forças de repressão da ditadura ${ }^{11}$. De qualquer modo, ao desenhar ou escrever sobre o conflito mundial de 1939-1945, Belmonte elaborou saborosas alusões à restritiva situação política do Brasil de então ${ }^{12}$, e alcançou fama internacional com o desenrolar da Segunda Guerra Mundial. Inspiradas nesse acontecimento, suas charges provocadoras foram publicadas em diversos países.

Os álbuns de coletânea das charges de Belmonte referentes ao conflito mundial constituem a maioria das suas publicações. São eles: No Reino da Confusão, Música, Maestro!, A Guerra do Juca e o mais famoso (e reeditado) deles, o Caricatura dos Tempos. Graças ao ofício de chargista, parte do trabalho de Belmonte ecoou pelas décadas seguintes, mas o mesmo não se pode dizer de suas crônicas e outros escritos, que permanecem quase que esquecidos.

Há nove produções culturais que se referem à obra de Belmonte. Produzidas em diferentes datas desde 1963, configuram-se em trabalhos acadêmicos, álbuns comemorativos, um documentário e sites na internet. Acompanhemos a caracterização delas e busquemos quaisquer informações relativas à atividade de escritor desempenhada por Belmonte, começando pela União Brasileira de Escritores - UBE - e suas informações, veiculadas no site de sua responsabilidade.

Em 1958 nasceu a UBE, cuja sede foi estabelecida em São Paulo. Alguns anos depois, ela lançou o Troféu Juca Pato, em homenagem a Belmonte, para premiar o Intelectual do Ano. No segundo semestre de 1962, em uma reunião da diretoria, o segundo vice-presidente, o escritor Marcos Rey, sugeriu que se criasse um prêmio para o melhor livro publicado naquele ano, e que, no conceito da maioria dos eleitores, fosse significativo para as letras e para a cultura brasileira. $\mathrm{O}$ autor receberia o título de Intelectual do Ano e qualquer escritor, da área literária ou não, poderia se inscrever. A votação, de alcance nacional, seria aberta, para que a disputa merecesse ampla divulgação, e concurso seria anual. A escolha do personagem de Belmonte para premiar o intelectual do ano, que foi defendida com empolgação pelo escritor Marcos Rey, deu-se porque o Juca Pato representava o inconformismo político, o debate de idéias, além de ser identificado intimamente ao "homem comum”, originário em larga medida das classes médias. Portanto, parece que os escritores da UBE optaram pelo Juca Pato como símbolo do troféu da casa porque ele abalaria a tradicional imagem de

\footnotetext{
${ }^{11}$ Ver Nélson Werneck Sodré. História da Imprensa no Brasil. Rio de Janeiro: Civilização Brasileira, 1966, p. 440-441. Ainda sobre a vigilância da polícia política do Período Vargas a artistas e intelectuais, ver Álvaro Gonçalves Antunes Andreucci e Valeria Garcia Oliveira (sob a coordenação e organização de Maria Luiza Tucci Carneiro). Cultura Amordaçada: intelectuais e músicos sob a vigilância do DEOPS. Inventário DEOPS Módulo VI - Comunistas. São Paulo: Arquivo do Estado/ Imprensa Oficial, 2002

${ }^{12}$ Ver Marcos Silva: “A Guerra de Belmonte: humor gráfico e política no Brasil durante a segunda guerra mundial”, In: Coggiola, Osvaldo [org.]. Segunda Guerra Mundial: um balanço histórico. São Paulo: Xamã/FFLCH-USP, 1995, pp. 337-348.
} 
que as letras seriam uma atividade para os "ricos e bem-educados”; os integrantes da União Brasileira de Escritores do ano de 1962 almejavam aproximá-las do "homem do povo” (leia-se: da classe média) ${ }^{13}$.

No site da União Brasileira de Escritores, Belmonte é apresentado como o criador do enervado Juca Pato, vítima da prepotência e do arbítrio dos poderosos. Mas não encontramos nenhuma referência às crônicas de Belmonte: ele simplesmente não é citado como escritor.

Nos anos setenta e noventa do século passado, foram lançados dois álbuns com o intuito de relembrar os desenhos de Belmonte. Em 1978, foi publicada uma coletânea de suas charges pela Secretaria da Cultura, Ciência e Tecnologia da cidade de São Paulo, em parceria com o MASP: Belmonte Presente ${ }^{14}$. Dezoito anos depois, em comemoração ao centenário do artista, a Editora Senac publicou outra coletânea de suas charges: Belmonte $100 \operatorname{anos}^{15}$. É necessário sublinhar, no entanto, que não há nenhuma publicação comemorativa sobre as crônicas de Belmonte. Após sua morte, elas caíram no esquecimento.

Os trabalhos acadêmicos que versam sobre a produção artística de Belmonte resumem-se a apenas três. Ainda que tenham relevância e qualidade, eles não estão voltados para as crônicas de Belmonte.

O primeiro trabalho acadêmico, um pequeno ensaio de autoria do professor Marcos Silva (DH-FFLCH-USP), discorre sobre a produção iconográfica de Belmonte direcionada para a crítica do Nazi-fascismo e da Segunda Guerra Mundial e, indiretamente, da situação política brasileira, profundamente restritiva e autoritária. Esse texto está inserido no livro organizado por Osvaldo Coggiola, Segunda Guerra Mundial: um balanço histórico ${ }^{16}$.

O segundo trabalho acadêmico, uma tese doutorado, aborda, junto com outros materiais e temas, a visão conflituosa de Belmonte frente à modernização acelerada da capital de São Paulo. A baliza cronológica da pesquisa compreende de 1920 até o ano da sua morte, em 1947. Ao mesmo tempo em que a autora, Regina Helena Alves da Silva, mostra o orgulho do artista perante a pujança da sua urbe natal, ela destaca suas charges repletas de críticas às mudanças incessantes perpetradas na cidade, sendo que estas estorvavam, desorientavam os paulistanos e geravam-lhes angústias. Mas a tese não se ocupa unicamente de Belmonte. Ele e sua obra pictórica se prestam como objeto de estudo para o terceiro capítulo, que possui o sugestivo título de “O Avesso, do Avesso, do Avesso do

\footnotetext{
${ }^{13}$ Para maiores informações, ver http://www.ube.org.br

${ }^{14}$ Belmonte Presente (São Paulo: Secretaria da Cultura, Ciência e Tecnologia - DACH - Comissão de Artes Plásticas MASP, 1978).

${ }_{15}^{15}$ Belmonte: 100 Anos (São Paulo: Editora Senac, 1996), organizado por Carvall.

${ }^{16}$ Ver Marcos Silva, op. cit.
} 
Avesso" ${ }^{17}$. A pesquisa tem como tema principal a imagem de modernidade par excellence construída em torno da capital paulista.

O terceiro trabalho, uma dissertação de mestrado de autoria de Andréa de Araújo Nogueira, teve como proposta a feitura de uma análise da representatividade do personagem Juca Pato, focalizando os anos de 1925 a 1927. A pesquisadora citou a elaboração de crônicas por Belmonte, ainda que sua dissertação estivesse direcionada para discussões voltadas às charges do Juca Pato ${ }^{18}$.

Tanto Regina Helena Alves da Silva como Andréa de Araújo Nogueira apresentaram, em seus trabalhos acadêmicos, o Juca Pato como um personagem das camadas médias ${ }^{19}$ e salientaram a forte identificação que estas tinham com o calunga. Sobretudo Nogueira, cujo tema de dissertação voltouse especificamente para os desenhos humorísticos de Belmonte que contavam com o Juca.

No princípio dos anos 1960, foi lançada uma monumental obra de quatro volumes sobre a história da charge e da caricatura no Brasil ${ }^{20}$. Seu autor, Herman Lima, foi um pesquisador de qualidade, mesmo não fazendo parte do corpo docente ou discente de Universidades.

Lima procurou estudar a obra de todos os chargistas e caricaturistas brasileiros que atuaram a partir da segunda metade do século XIX; logo, foram dedicadas dez páginas à obra de Belmonte. Ainda que o objeto principal da análise fossem as charges e as caricaturas, ele terminou por corroborar a opinião de Monteiro Lobato sobre a escrita de Belmonte:

\begin{abstract}
Belmonte é um artista integral. Tanto caricatura com o lápis como por meio da palavra escrita. Quero dizer que é um escritor notável - dêsses cujas crônicas os jornais estampam em tipo de relevo. A mesma finura de humor que mostra no desenho ressalta dos seus comentários escritos. ${ }^{21}$
\end{abstract}

Para Lima, as crônicas de Belmonte revelavam, realmente, “...um escritor que se sobrepunha em muito ao rabiscador das charges do mesmo jornal, por mais vigorosas que muitas vezes essas conseguiam ser."22.

\footnotetext{
${ }^{17}$ Cf. Regina Helena Alves da Silva. São Paulo. A Invenção da Metrópole. São Paulo: FFLCH-USP, 1997. (Tese de Doutorado)

${ }^{18}$ Ver Andréa de Araújo Nogueira, op. cit.

${ }^{19}$ Juca Pato não se vestia como um burguês: ainda que usasse fraque, gravata borboleta, polainas e sapatos, os punhos de sua camisa estavam sempre por cerzir, assim como seu fraque.

${ }^{20}$ Ver Herman Lima. História da Caricatura no Brasil - volume IV. Rio de Janeiro, José Olympio, 1963, pp. 1362-1372.

${ }^{21}$ Prefácio escrito por José Bento Monteiro Lobato para um álbum de charges de Belmonte - A realidade Brasileira que não chegou a ser publicado. Cf. Herman Lima, op. cit., p. 1372.

${ }^{22}$ Herman Lima, op. cit., p. 1371.
} 
Ademais, não passou despercebido a esse estudioso o antifascismo de Belmonte. Entretanto, Lima ignorou que essa firme concepção política do artista tivesse surgido bem antes dos últimos anos da década de 30, pois já estava presente nas crônicas e nos desenhos humorísticos de 1932/1933.

Além das obras escritas, há também um belo e sensível documentário de onze minutos sobre a vida e a obra Belmonte, produzido em 1981 pelo Diretor Ivo Branco ${ }^{23}$, no qual se dá destaque especial às charges. A atividade de cronista desenvolvida quase que diariamente pelo artista foi citada en passant. Mais uma vez, notamos que o aspecto mais sublinhado na totalidade da obra belmonteana é a série de desenhos humorísticos.

A página on-line do jornal Folha de São Paulo disponibiliza informações sobre os trabalhos de seus colaboradores de hoje e de outrora ${ }^{24}$, dentre os quais, além de Belmonte, figuram Rubem Braga, Plínio Marcos, Alfredo Bosi, Modesto Carone e muitos outros. Nesse site, nosso autor é festejado como o criador do Juca Pato e como um dos maiores chargistas brasileiros de todos os tempos, mas sua atividade de cronista é, de novo, apenas citada. Nessa mesma página podemos encontrar alguns links para a leitura de escritos de Belmonte - treze no total -, sendo a maior parte deles crônicas publicadas entre 1933 e 1946. Entretanto, elas não são identificadas como tal, sendo agrupadas sob a abrangente palavra “textos".

Portanto, se na atualidade Belmonte tem seu trabalho de chargista mais ou menos conhecido, suas crônicas estão praticamente olvidadas, o que é incompreensível e injusto, pois seus escritos presenteiam o leitor com inteligência e uma fina ironia. As crônicas de Belmonte raramente desencadeiam o riso exagerado, o ato de gargalhar. Proporcionam antes o riso discreto, próprio de quem tem diante de si um desvelamento perspicaz do cotidiano. Não há indícios que conduzam a uma explicação do porquê do esquecimento por parte de pesquisadores acadêmicos e outros estudiosos de suas crônicas.

Nesse sentido, acreditamos que a proposta de análise das crônicas de Belmonte nos conduziu a um campo inexplorado, bastante aberto à reflexão. É esta expectativa de ineditismo que impulsionou a presente pesquisa.

Optamos, também, pela análise das crônicas no jornal Folha da Noite porque elas foram publicadas em princípios/meados da década de trinta, período profundamente conturbado e que, justamente por isso, desperta grande interesse à pesquisa histórica. Olhando em retrospectiva para os anos trinta, vemos os reflexos da crise estrutural da economia capitalista, a luta dos movimentos de trabalhadores liderados por anarquistas e comunistas, a fragilidade da democracia liberal e o pleno

\footnotetext{
${ }^{23}$ É possível vê-lo no seguinte endereço: http://www.portacurtas.com.br.

${ }^{24}$ Ver a Seção Banco de Dados “AUTORES”, em http://almanaque.folha.uol.com.br.
} 
avanço dos regimes nazi-fascistas e de seus congêneres, como a Ação Integralista Brasileira. Esse panorama político e econômico deveras problemático se repetiu, com maior ou menor intensidade, em praticamente todo o mundo ocidental.

No Brasil, esses anos foram igualmente de muita instabilidade política, entrecortados por uma guerra civil em 1932, pela movimentação de militares golpistas nos bastidores de um governo com propensões autoritárias e que se via obrigado a preparar uma Constituição (1934), mas que, justamente por este panorama antidemocrático, estava fadada, desde seu nascimento, ao fracasso. Estes anos foram entrecortados também pela intensificação da luta entre a esquerda, corporificada principalmente pela ANL, e os integralistas, pela censura e pela repressiva Lei de Segurança Nacional, estabelecida no primeiro semestre de 1935.

Por fim, deve ser assinalada como mola propulsora deste trabalho a afeição que desenvolvemos pela obra de Belmonte, sentimento que se reafirmou com a leitura de cada crônica.

Também almejamos, com a nossa pesquisa, oferecer uma contribuição à História da Imprensa Liberal de São Paulo daquele período, tema de estudo muito amplo, mas que, em desacordo com a sua importância, até o presente foi contemplado por poucos pesquisadores - ainda que o trabalho destes apresente qualidades indiscutíveis.

Uma obra muito importante sobre a imprensa paulista liberal dos anos de 1920-1940 é O Bravo Matutino ${ }^{25}$, de Maria Helena Capelato e Maria Lígia Prado. As autoras analisam as concepções políticas e econômicas do jornal O Estado de São Paulo (OESP), usando como fonte seus editoriais. Outra pesquisa de boa qualidade é, também de Maria Helena Capelato, Os Arautos do Liberalismo $^{26}$. Capelato analisa a ideologia dos jornais liberais e burgueses de São Paulo que tiveram uma significativa participação na política do estado e do país: OESP, Folha da Noite, Folha da Manhã, Diário Nacional, A Gazeta e O Correio Paulistano, entre outros. Para a autora, o positivismo evolucionista de Hebert Spencer seduzia as mentes dos jornalistas e editores da época.

Sobre a visão de mundo veiculada pelos editoriais das Folhas, há ainda o livro de Carlos Guilherme da Mota e Maria Helena Capelato, História da Folha de São Paulo (1921-1981) ${ }^{27}$, embora se trate de uma obra de caráter mais panorâmico e descritivo.

\footnotetext{
${ }^{25}$ Maria Helena Capelato e Maria Ligia Prado. O Bravo Matutino (Imprensa e ideologia no jornal "O Estado de São Paulo”). São Paulo: Alfa-Omega, 1980.

${ }^{26}$ Maria Helena Capelato. Os Arautos do Liberalismo. Imprensa Paulista (1920-1945). São Paulo: Brasiliense, 1989, p. 27.

${ }^{27}$ Ver Carlos Guilherme da Mota \& Maria Helena Capelato. História da Folha de São Paulo (1921-1981), São Paulo: IMPRES, 1980.
} 
Outra obra que analisa a concepção dos jornais paulistas liberais é Getúlio Vargas e a Oligarquia Paulista ${ }^{28}$, de autoria de Vavy Pacheco Borges, em que são constatadas diferenças consideráveis na manipulação da imagem de Getúlio Vargas naqueles órgãos de Imprensa entre os anos de 1926 e 1932.

Em sua obra sobre o Partido Democrático de São Paulo ${ }^{29}$, Maria Lígia Prado dedica um capítulo à ideologia do Diário Nacional, órgão jornalístico do partido paulista em questão. A autora sublinha que ele estava em conformidade com as concepções da imprensa paulista liberal e burguesa da época ${ }^{30}$.

Há também a obra geral clássica sobre a imprensa brasileira: História da Imprensa no Brasil $^{31}$, de Nélson Werneck Sodré. Com limites bastante alongados, que englobam os séculos XIX e XX até a década de sessenta, essa detalhada pesquisa abrange a história de praticamente todos os jornais que tiveram uma certa durabilidade, especialmente nas capitais dos estados brasileiros. De qualquer modo, foi dada uma ênfase maior ao eixo Rio de Janeiro - São Paulo.

A tese de doutorado de Gisela Taschner Goldenstein, defendida em 1986 na FFLCH/USP (Folhas ao Vento: contribuição ao estudo da indústria cultural no Brasil ${ }^{32}$ ), objetivou precisar quando a lógica de produção de mercadorias passou a reger a confecção de um produto específico (o jornal) e em que época a imprensa (no caso do estudo, o grupo Folhas) adotou a forma empresarial como diretriz determinante. De qualquer modo, no primeiro capítulo de sua tese, a autora faz uma interessante recapitulação da história das Folhas - da fundação, em 1921, até o final dos anos quarenta - e salienta características específicas da Folha da Noite e da Folha da Manhã referentes à forma de apresentação da mensagem.

A Dissertação de Mestrado Imprensa, ditadura e democracia: a construção da auto-imagem dos jornais do grupo Folhas (1978/2004), de Elaine Muniz Pires ${ }^{33}$, aborda período posterior ao que pesquisamos, embora faça alusões gerais a momentos históricos anteriores.

\footnotetext{
${ }^{28}$ Vavy Pacheco Borges, Getulio Vargas e a Oligarquia Paulista: história de uma esperança e muitos desenganos. São Paulo: Brasiliense, 1979.

${ }^{29}$ Maria Lígia Coelho Prado, A Democracia Ilustrada (O Partido Democrático em São Paulo, 1926-1934), São Paulo: Editora Ática, 1986.

${ }^{30}$ Essa imprensa paulista burguesa era favorável às idéias liberais, como autonomia estadual alicerçada em um Estado brasileiro federalizado e democracia formal (fim da censura e transparência nas eleições). Entretanto, as classes trabalhadoras despertavam-lhe um profundo temor, principalmente quando elas se organizavam para lutar contra a exploração. Logo, a democracia idealizada por essa imprensa, da qual as Folhas faziam parte, tinha limites de classe muito bem estabelecidos. Ver Maria Helena Capelato, op. cit., pp. 19-25.

${ }^{31}$ Nélson Werneck Sodré. História da Imprensa no Brasil. Rio de Janeiro: Editora Civilização Brasileira, 1966.

${ }^{32}$ Gisela Taschner Goldenstein. Folhas ao vento: contribuição ao estudo da indústria cultural no Brasil. São Paulo: FFLCH-USP, 1986, pp. 01-62. (Tese de Doutorado)

${ }^{33}$ Elaine Muniz Pires. Imprensa, Ditadura e Democracia: a construção da auto-imagem dos jornais do grupo Folhas (1978/2004). São Paulo: PUC-SP, 2008. (Dissertação de Mestrado)
} 
Para a presente pesquisa, certos temas devem ser apontados nas crônicas de Belmonte por causa da recorrência insistente: rejeição ao Governo Vargas, repulsa ao Nazi-fascismo, defesa do liberalismo político e da democracia, e severas críticas à modernidade. Se essas temáticas são tão comuns na escrita de Belmonte ${ }^{34}$, o que elas poderiam significar para o artista e seu público naqueles anos profundamente tumultuados da primeira metade da década de trinta? As opiniões de Belmonte, expressas em sua escrita, estavam em conformidade com aquelas divulgadas nos editoriais da Folha da Noite ou divergiam delas? Essas são as indagações que tentamos contemplar e, parcialmente, responder.

No primeiro capítulo desta dissertação, desenvolvemos um panorama geral dos jornais paulistas liberais daquele período. Nele, nos direcionamos mais para um estudo sobre a Folha da Noite e procuramos investigar suas características e público leitor. Acrescentamos nas páginas finais deste capítulo uma biografia de Belmonte.

No segundo, buscamos compreender porque as crônicas inspiravam sentimentos tão desencantados perante um novo que politicamente se impunha: o Governo Provisório, transformado, em 1934, em República Nova. Mergulhamos, neste capítulo, no pensamento coletivo de milhares de paulistas das camadas médias urbanas - por meio da leitura das crônicas e também dos editoriais do jornal e de farta bibliografia -, e procuramos entender o que o desenrolar do novo governo dos revolucionários em 1930, 1932 e 1934 significou para os paulistas das camadas médias e para o artista.

No terceiro capítulo, almejamos compreender a visão que Belmonte tinha do Nazi-fascismo, que, por sua vez, também se apresentava como uma grande inovação no panorama político europeu de então, assim como o governo de Getúlio Vargas, no Brasil. Com relação a este tema, o artista ousou ir bem mais além do que a imprensa liberal de sua época; em suas crônicas, ele mostrou precocemente uma visão crítica perante o Nazi-fascismo, o que era bastante incomum entre os jornalistas da época.

No quarto e último capítulo, investigamos a visão de Belmonte perante a modernidade técnica, o porquê de suas concepções (geralmente) negativas sobre ela, e a relação que se pode estabelecer entre as temáticas abordadas pelo escritor.

\footnotetext{
${ }^{34}$ As crônicas de crítica ao Nazi-fascismo representam $10 \%$ do material que foi publicado em dois anos e meio. No entanto, reservamos um capítulo para elas dado o ineditismo do posicionamento antifascista de Belmonte na imprensa liberal de então. Já as temáticas referentes à oposição ao governo de Getúlio Vargas e de crítica à modernidade técnica compõem a maior parte do trabalho do artista. Entremeada com essas temáticas, a valorização da democracia liberal é sempre recorrente.
} 


\section{As Folhas, as Crônicas e seus Leitores}

A Folha da Noite foi criada em 1921, na cidade de São Paulo. Seu sucesso de vendas foi suficiente para impulsionar os editores da Folha na criação de um matutino em 1925: a Folha da Manhã. Os dois órgãos, enquanto estiveram sob a direção do grupo de Olival Costa e Pedro Cunha, almejaram atrair leitores das camadas médias. Nessa fase, suas características eram o fiscalismo da urbe paulistana e a influência pequeno-burguesa, além da oposição ao Partido Republicano Paulista (PRP) e do apoio ao Partido Democrático (PD) ${ }^{35}$. Mas em 1930, às vésperas do movimento de outubro, as Folhas subitamente se colocam contra a "Revolução", porque esta dava indícios, no entendimento de seus redatores-chefes, de ser “contra São Paulo”. Logo, esses jornais terminaram “empastelados” e seus donos, falidos, optaram pela venda da empresa jornalística.

\subsection{Panorama Geral da Imprensa Liberal Paulista}

O número de publicações liberais que circulava no estado de São Paulo entre 1932 e 1935 era elevado. Entretanto, havia aqueles jornais que tinham maior influência e participação na política do estado e do país: OESP, as Folhas, Diário da Noite, Diário de São Paulo, Diário Nacional, O Correio Paulistano e A Gazeta ${ }^{36}$. Estes eram os principais porta-vozes dos liberais paulistas, ou, segundo Maria Helena Capelato, eles constituíam-se nos arautos do liberalismo. De um modo geral, defendiam a liberdade de comércio, a democracia representativa, o individualismo e a autonomia estadual - o federalismo.

Ainda que voltados para a veiculação do ideário liberal, os editoriais desses periódicos denotavam sensíveis diferenças de opinião, se comparados. O OESP e os Diários (da Noite e de São Paulo), por exemplo, eram grandes defensores da industrialização. E também exaltavam a ciência e os avanços técnicos, identificados com o progresso. As Folhas, por sua vez, se mostravam favoráveis ao conhecimento científico, mas viam os avanços tecnológicos sob dois sentidos: os armamentos modernos configuravam-se em uma real ameaça para os seres humanos, mas, ao mesmo tempo, o desenvolvimento tecnológico poderia conduzir a um maior progresso material e intelectual, o que, na

\footnotetext{
${ }^{35}$ Ver Nélson Werneck Sodré, op. cit. Ver também Carlos Guilherme Mota e Maria Helena Capelato, op. cit.

${ }^{36}$ Cf. Maria Helena Capelato, 1989, p. 27.
} 
visão de seus editorialistas, seria muito benéfico para as sociedades humanas. De um modo geral, a imprensa liberal elogiava o desenvolvimento da ciência e da técnica.

Em princípios de 1931, Octaviano Alves de Lima (1931-1945), cafeicultor e fazendeiro de relevância, adquiriu a empresa jornalística com o intuito de defender os interesses da lavoura, principalmente os da cafeicultura. Fazendeiro de café em Campinas, o novo proprietário da Folha também estava ligado, como exportador, ao comércio do produto. Portanto, o novo proprietário das Folhas impôs uma outra proposta editorial para seus periódicos. Eles teriam que veicular os “interesses da lavoura”, e não mais apenas os anseios e protestos das camadas médias urbanas. Consequentemente, a partir dos anos 30, ao contrário de OESP, que se engajou na defesa do industrialismo, as Folhas passaram a propugnar as atividades rurais.

No panorama da imprensa do período, a Empresa Folha da Manhã estava voltada, sobretudo, para as questões paulistas e paulistanas que preocupavam a elite cafeicultora e parte das camadas médias desse estado; para a produção e a venda do café, produto que ela qualificava como a preciosa riqueza de São Paulo, para a relação conflituosa dos cafeicultores dessa região com o governo de Getúlio Vargas e para a defesa do liberalismo econômico. Era freqüente, nos editoriais da Folha da Noite, a valorização da liberdade de comércio, a exigência da mudança dos impostos, que recaíam sobre a riqueza e a produção, e a proposta de reforma tributária.

Formado em 1933, o Partido da Lavoura tinha como proposta o apoio irrestrito aos interesses dos cafeicultores e suas porta-vozes por excelência tornaram-se a Folha da Noite e a Folha da Manhã de Alves de Lima. A Folha da Manhã defendia, portanto, a vocação agrária do país, em contraposição à atividade industrial. Para esta empresa jornalística, o Brasil precisava investir naquilo que tinha de melhor, nas suas vantagens naturais. Logo, ela era absolutamente contrária ao apoio do governo à indústria brasileira.

Mas ainda que a totalidade dos liberais paulistas valorizasse a cafeicultura, parte considerável deles também era a favor da industrialização. O OESP e os Diários de Chateaubriand eram mais enfáticos na defesa do desenvolvimento da maquinofatura no Brasil. Já a Gazeta e, sobretudo, as Folhas defendiam o ponto de vista dos fazendeiros. Todavia, “... se a perspectiva agrarista dividia os representantes da imprensa liberal, num ponto, porém, havia concordância: o livre comércio deveria nortear a política econômica do país, e o individualismo era um princípio sobre o qual não se fazia concessão de nenhuma espécie”. 37

Com relação ao regime político propugnado pelos liberais brasileiros, havia a defesa da democracia, vista como um governo ideal, ainda que ela devesse estabelecer limites de classe bem

\footnotetext{
${ }^{37}$ Idem, ibidem, pp. 48-50.
} 
definidos. Isso significava que os liberais defendiam uma democracia mais formal, onde os cargos governamentais fossem ocupados exclusivamente por indivíduos “bem-nascidos” e “bem-educados”. A proibição do direito de voto aos analfabetos era, por si só, uma forma de a elite brasileira restringir a participação política da maior parte das massas populares, uma vez que o desconhecimento das letras era uma condição que abrangia cerca de $70 \%$ da população brasileira do período ${ }^{38}$. Nesse sentido, o empolgado discurso favorável à democracia, sempre presente nos jornais, ocultava a desigualdade e o controle social, tão importantes para os liberais.

O controle e a repressão das classes desvalidas estavam intrinsecamente relacionados com a defesa irrestrita do direito de propriedade pelos liberais, o que explica, também, a boa acolhida da imprensa paulista às idéias de John Locke, afinal este filósofo teve grande importância para a fundamentação da sociedade e cultura burguesas ${ }^{39}$. Podemos entender, portanto, que a valorização do individualismo, tão propalada pelo liberalismo, não dizia respeito às operárias das indústrias têxteis paulistas, que trabalhavam de pé por mais de dez horas diárias em troca de um salário insuficiente, ainda menor que o masculino. Dela também estavam excluídos os miseráveis trabalhadores rurais, que apresentavam um alto número de analfabetos em suas fileiras. Definitivamente, o discurso liberal valorizador do individualismo era endereçado às classes dominantes e às camadas médias, mas ignorava as classes trabalhadoras - problema que também se manifestava noutros países da época.

Os liberais defendiam entusiasticamente a autonomia política e econômica dos estados, cujo modelo era o federalismo norte-americano. Para um estado rico e influente como São Paulo, a autonomia e a liberdade econômica eram escolhas interessantes. Entretanto, os liberais paulistas e seus porta-vozes diários eram um tanto maleáveis com relação a este aspecto, considerando-se que os governos brasileiros apoiaram financeiramente o café durante muitos anos, tanto na Primeira República como na República Nova, e o mesmo seria feito com a indústria nacional, especialmente a partir da segunda metade dos anos 30. E os próprios jornais liberais, com destaque para as Folhas e OESP, exigiam a presença do Estado na saúde, e, sobretudo, na educação. Para a elite paulista havia a recém-criada Universidade de São Paulo (1934) e a Escola de Sociologia e Política. Às classes trabalhadoras, os periódicos propugnavam uma educação pública e gratuita voltada para o

\footnotetext{
${ }^{38} \mathrm{O}$ número de brasileiros alfabetizados é informado em uma coluna impressa na Folha da Noite, baseada em estatísticas do ano de 1926. Ele alcançava apenas 10 milhões de pessoas, em uma população que superava os trinta e cinco milhões de habitantes. Das crianças em idade escolar, apenas 23,76\% recebiam instrução em estabelecimentos públicos ou privados. Cf. Folha da Noite (São Paulo), “Idéas e Factos - o que o Brasil perde com o analphabetismo”. Publicada em 18/11/1932, na p. 3.

39 Cf. Maria Sylvia de Carvalho Franco. "All the Words was America”, in: Revista USP, Dossiê Liberalismo $e$ Escravidão. São Paulo: Universidade de São Paulo, n. 17, 1993, pp. 30-53 passim. Ver também Maria Helena Capelato, 1989, pp. 21-22 e pp. 72-75.
} 
ensinamento da moral, do civismo, das letras, da matemática e de cursos técnicos ou profissionalizantes ${ }^{40}$.

Praticamente todos os jornais liberais de São Paulo, tanto as Folhas como O Estado de São Paulo, O Correio Paulistano, A Gazeta, o Diário Nacional e os Diários de Assis Chateaubriand (o Diário da Noite e o Diário de São Paulo) compartilhavam da ideologia da paulistanidade ${ }^{41}$ - ou do conjunto de idéias que cristalizava o sentimento de superioridade do homem paulista em relação aos brasileiros de outros estados.

Ainda que as crônicas de Belmonte fossem publicadas ao lado do editorial, os assuntos sobre os quais elas discorriam, não raramente, eram diferentes daqueles abordados pelos editorialistas. Estes defendiam, e com constância, o liberalismo econômico irrestrito. Em contrapartida, não foram muitas as crônicas que se voltaram para este tema. Por outro lado, se o panorama político internacional era pouco comentado nos editoriais, sua abordagem ocorria com muito mais freqüência na literatura humorística de Belmonte.

Já a exaltação do desenvolvimento econômico do estado de São Paulo, assim como a de sua liderança política no decorrer da história do Brasil, era encontrada, e com presença marcante, tanto nos editoriais como nas crônicas. Mas com mais freqüência nos primeiros do que nas segundas.

Quanto à origem social do público leitor de Belmonte, nosso trabalho de pesquisa permite-nos sugerir que ele era constituído principalmente pelas classes médias da população urbana.

Classe média, classe média baixa, classe social: Para o marxismo, é a relação dos homens com os meios de produção que determina a constituição das classes sociais. Nessa perspectiva, todas as sociedades de todos os períodos históricos presenciaram a luta entre duas classes antagônicas: os proprietários e os trabalhadores não-proprietários.

Se partirmos de uma leitura superficial do modelo dicotômico, conceberemos a sociedade capitalista dividida em apenas duas grandes classes antagônicas: a burguesia e o proletariado. Entretanto, para Rodolfo Stavenhagen, não há oposição entre o modelo dicotômico e a aceitação da existência de outras classes sociais. Ele alerta que

Na medida em que uma sociedade está caracterizada pelo modo de produção predominante, as classes antagônicas desse modo de produção são as classes fundamentais dessa sociedade. Mas (...) não se deve esquecer que a visão dicotômica

\footnotetext{
${ }^{40}$ Cf. Maria Helena Capelato, 1989, pp. 85-88, pp. 144-151 passim e p. 202.

${ }^{41}$ Esse conceito será explicitado no capítulo 3.
} 
corresponde a um modelo teórico de um sistema econômico, que não se encontra em parte alguma em seu estado puro. Portanto, a divisão da sociedade exclusivamente em duas classes antagônicas representa uma tendência histórica e não uma realidade de cada etapa histórica ${ }^{42}$.

A visão dicotômica não se opõe à analise de situações históricas particulares em que atuam diversas classes e frações de classes como forças econômicas e políticas concretas. Não apenas as obras históricas de Marx apresentam muitas análises desse tipo como também as de outros teóricos e práticos do marxismo como Lênin e Mao Tsé-Tung. ${ }^{43}$

Partindo do pressuposto de que frações majoritárias do público leitor de Belmonte pertenciam aos extratos médios da sociedade, é necessário levarmos em conta algumas leituras clássicas para podermos compreendê-los melhor. Optamos pela consulta dos trabalhos de Décio Saes e Paulo Sérgio Pinheiro, importantes estudiosos deste assunto.

Ambos os autores atentaram para a dificuldade em definir as classes médias brasileiras, uma vez que o nível de vida delas oscila com alguma constância.

Na concepção de Décio Saes, as camadas médias dos anos 1920-30 tornam-se menos obscuras se buscarmos defini-las pela origem de seus membros, pela sua renda, e, sobretudo, pela sua posição no processo social de produção. Nesse sentido, ele verificou duas classes médias distintas: uma primeira, chamada de classe média tradicional ou “despossuída”, seria aquela que conhecemos por classe média alta. Segundo Saes, ela descendia da aristocracia empobrecida que, especialmente no caso de São Paulo, fora à Capital do estado para ser apadrinhada pelos “primos ricos”, os cafeicultores prósperos. Com eles, essa gente e seus descendentes tiveram acesso a bons empregos na cidade: cargos burocráticos de relevância, profissões liberais prestigiosas e postos de direção na administração privada ${ }^{44}$.

Já os indivíduos pertencentes à classe média baixa provinham principalmente do interior do país ou eram descendentes de imigrantes. Tinham alguma instrução, mas realizavam funções pouco prestigiosas de trabalho não-manual: eram empregados de bancos, de escritórios, ou ocupavam um cargo público na burocracia inferior ${ }^{45}$. A situação de trabalho dessa classe média baixa a diferenciava

\footnotetext{
${ }^{42}$ Rodolfo Stavenhagen. "Estratificação Social e Estrutura de Classes”. In: Velho, Otávio Guilherme (Org.). Estrutura de classes e estratificação social. Rio de Janeiro: Zahar, 1977, p. 159.

${ }^{43}$ Rodolfo Stavenhagen, op. Cit., p. 160.

${ }^{44}$ Ver Décio Saes Classe Média e Sistema Político no Brasil. São Paulo: T. A . Queiroz, 1984, pp. 43-44.

${ }^{45}$ Idem, ibidem, p. 45.
} 
da classe média alta, pois ela se deparava com um baixo nível de remuneração e com a ausência de poder decisório pessoal ${ }^{46}$.

Décio Saes discorre sobre a opção política das duas classes médias: a tradicional, por causa das suas relações familiares e do "apadrinhamento profissional” oferecido pelos cafeicultores, tendia a possuir concepções liberais ${ }^{47}$ muito próximas daquelas professadas pela elite paulista ${ }^{48}$. Já a classe média baixa tinha uma concepção política bastante variável: se por vezes, apoiava aspectos da luta dos operários, havia parcelas que sentiam simpatia pelo liberalismo propalado pela elite. As opções políticas da classe média baixa apontavam para uma verdadeira “colcha de retalhos” ideológica: parte apoiou a Ação Integralista Brasileira; outra parcela deu apoio aos trabalhadores e à Aliança Nacional Libertadora; mas uma fração - pequena, se comparada com o apoio maciço oferecido pelas classes médias altas - optou pela proposta liberal da elite paulista, veiculada por jornais como as Folhas, OESP, os Diários e outros. Observa-se, portanto, diversidade nas opções políticas desse setor social.

O autor engloba, em sua definição de classe média, indivíduos que não eram donos de meios de produção e realizavam trabalho não-manual ${ }^{49}$. A pequena burguesia, muitas vezes direcionada a um trabalho manual - por exemplo sapataria, loja de costura ou carpintaria -, não está presente na obra desse autor como representante das classes médias. Saes justifica a exclusão da pequena burguesia de suas análises partindo do pressuposto de que as diferentes posições no processo social de produção dos pequenos proprietários e das classes médias “modernas” - trabalho não-manual, não propriedade dos meios de produção - não permitem a unificação dos dois grupos ao nível estritamente ideológico ${ }^{50}$. No entanto, nesse ponto, há um desencontro entre a teoria do autor e a visão de classe média impressa em nossas fontes. Nelas, observamos a presença de comerciantes e alfaiates, donos de seus próprios negócios, coagidos por problemas urbanos e administrativos e ombreando-se com escrivões de cartório e de polícia, com professores primários e funcionários de bancos. Assim, nossas fontes sugerem que a camada média reconhecia-se não exatamente pela sua

\footnotetext{
${ }^{46}$ Ver Décio Saes, “Classe Média e Sistema Político no Brasil 1930-1964”, in: Fausto, Boris (org.). História Geral da Civilização Brasileira - Sociedade e Política (I930 - 1964) - volume III. São Paulo: Difusão Européia do Livro, 1984, p. 455.

${ }^{47}$ Idem, ibidem, p. 454-455 e p. 463-466.

${ }^{48}$ Ao usar a palavra elite, estamos nos referindo a grupos que, por origem social ou por "talento", têm grande poder econômico e político, a ponto de comandarem o seu país. A referência de elite dos anos 20 e início dos 30 ainda estava ligada aos cafeicultores paulistas. Na maior parte dos casos, essa elite cafeicultora paulista era também paulistana, pois residia na cidade de São Paulo, apesar da sua fonte de renda principal estar localizada no interior do estado. Ainda que, após 1930, os cafeicultores paulistas tivessem que competir pelo poder político com grupos (muitas vezes) exógenos ao estado de São Paulo, eles prosseguiram influenciando nas diretrizes político-econômicas do Brasil, mas com menos preponderância.

${ }^{49}$ Idem, ibidem, p. 449-452.

${ }^{50}$ Idem, ibidem, p. 449.
} 
posição no processo social de produção, mas, sobretudo, pela vida que levava, pelas dificuldades enfrentadas no dia-a-dia e por seu poder de consumo.

Na crônica Os Presos, temos um escrivão que compra papel, pena e tinta com os “... magérrimos tostões...” ${ }^{51}$ do seu ordenado para dar prosseguimento ao trabalho, pois as "autoridades competentes” não abastecem os cartórios com esses materiais. Há também o Sr. Pyrilampo de Souza Carvalhosa, que, ao pegar o bonde com o narrador, engata uma conversa com ele e se apresenta como “... funcionário bancário, pae de família, eleitor e pobre” ${ }^{52}$.

Paulo Sérgio Pinheiro voltou-se para o estudo das classes médias da Primeira República e, diferentemente de Décio Saes, considera a existência de antigas classes médias, dedicadas ao pequeno comércio e à pequena produção (formas de artesanato ou de pequenas empresas familiares), e de novas classes médias, voltadas para o funcionalismo público, para trabalhos assalariados em comércios, bancos e escritórios e para profissões liberais e intelectuais, como medicina, advocacia, jornalismo e magistério. Pinheiro salientou que a crescente onda de urbanização brasileira nos séculos XIX e XX fez todas as frações das classes médias aumentarem ${ }^{53}$, principalmente em São Paulo e no Rio de Janeiro.

Tanto Paulo Sérgio Pinheiro como Décio Saes afirmam que as classes médias têm uma oscilação política basculante, ainda que observem a tendência das médias altas em apoiar as propostas das elites. Saes defende que parte considerável das classes médias brasileiras dos anos vinte e trinta teve um papel eminentemente conservador ao se posicionar ao lado do agrarismo da oligarquia cafeeira e contra a industrialização ${ }^{54}$.

Um aspecto que, por vezes, está presente nas crônicas e que parece ser uma queixa freqüente das classes médias, é o protesto contra os impostos, que apertavam o orçamento das famílias. Na crônica Carta aberta ao prof. Desiderius Paap, de 08/02/1934, no último parágrafo, o artista comenta que o governo continuava a inventar impostos e, justamente por isso, os alfaiates já andavam armados. Na crônica Economias!, de 28/11/1933, em Pague e não bufe!, de 26/03/1934, e em Retribuindo visitas, de 25/07/1934, existem novamente críticas com relação aos impostos e à criação de outros tantos. Nos primeiros anos da década de 30, a persistência de preços vis na

\footnotetext{
${ }^{51}$ Ver Belmonte, op. cit., p. 141.

52 Belmonte, “Idéas de um homem prático”. Op. cit., p. 180.

${ }^{53}$ Ver Paulo Sérgio Pinheiro. “Classes Médias Urbanas: formação, natureza, intervenção na vida política.” In: Fausto, Boris (org.). História Geral da Civilização Brasileira - Sociedade e Instituições (1889-1930) - Tomo III / Volume II. Rio de Janeiro: Bertrand Brasil, 1997, p. 16-17.

${ }^{54}$ Sobre esse assunto, ver Décio Saes, “Classe Média e Sistema Político no Brasil 1930-1964”. In: Fausto, Boris (org.) História Geral da Civilização Brasileira - Sociedade e Política (I930 - 1964) - volume III. São Paulo: Difusão Européia do Livro, 1984. Ver Décio Saes. Classe Média e Sistema Político no Brasil. São Paulo: T. A . Queiroz, 1984, e também Boris Fausto. A Revolução de 1930 (historiografia e história). São Paulo: Brasiliense, 1976.
} 
exportação e a crise geral fizeram com que o governo forçasse a ampliação de suas fontes de renda: houve aumento do imposto de consumo, pretendeu-se acabar com certos direitos financeiros dos estados, que seriam englobados pela União, e aumentou-se o imposto de renda ${ }^{55}$.

Assim como as críticas referentes aos impostos, a carestia e o alto valor dos produtos de primeira necessidade também são problemas que entremeiam as linhas de algumas das crônicas. Segundo Edgard Carone ${ }^{56}$, os anos de 1934 e 1935 foram bastante intranquilos, tomados por manifestações sociais nas maiores cidades do país, e elas tiveram, em grande parte, a participação das classes operárias e médias, impulsionada, sobretudo, pela alta do custo de vida e da inflação.

Em relação ao público leitor específico do jornal Folha da Noite, ao fazermos uma comparação do plano da organização da mensagem e da seleção das notícias dos periódicos Folha da Noite e Folha da Manhã, percebemos que ambos se diferenciavam bastante em sua forma de apresentação durante os anos trinta. O segundo tinha um tom mais sério e possuía uma média de duas a três páginas consagradas à cotação das bolsas de valores e a informações referentes ao comércio do café; discussões sobre a situação econômica interna e externa eram mais aprofundadas e especificadas na Folha da Manhã. O Jornal vespertino tinha um número médio de oito páginas e a Folha da Manhã frequentemente era impressa com doze páginas. Esse matutino era publicado de terça a domingo, sendo que sua edição dominical, impressa em novo formato a partir de 1931, tinha também um suplemento direcionado para o lazer e a diversão, e nele Belmonte publicava belíssimos desenhos ilustrativos. O jornal dominical, acrescentado do suplemento, atingia uma média de 24 páginas.

Por sua vez, a Folha da Noite era impressa de segunda a sábado. Diferentemente do matutino, ela ostentava poucas informações sobre a economia e as bolsas, e atentava com mais ênfase para os problemas das cidades de São Paulo ${ }^{57}$, na segunda página (e às vezes na terceira também) do lado esquerdo, na coluna “À margem dos factos”. A composição visual da Folha da Noite era mais despojada do que aquela apresentada pela Folha da Manhã: ela veiculava diariamente charges e caricaturas e, além disso, uma página toda (que podia ser a seis, a sete ou a oito) apresentava fatos policiais, tragédias amorosas e desastres aéreos ou automobilísticos, fartamente ilustrados com fotografias. E a Folha da Noite dava muito mais destaque para os esportes e as sessões de cinema do que a Folha da Manhã, destinando-lhes cerca de três páginas.

\footnotetext{
${ }^{55}$ Cf. Edgard Carone. A República Nova (1930-1937). São Paulo, DIFEL, 1982, p. 69.

${ }^{56}$ Idem, ibidem, p. 331.

${ }^{57}$ Especialmente para os problemas da capital do estado - impostos abusivos, falta de segurança, ruas esburacadas e transporte público ineficiente.
} 
Após as observações apresentadas acima, podemos sugerir que provavelmente os públicos dos dois jornais eram diversos, tinham origens sociais diferentes. Se lermos o editorial de apresentação da Folha da Noite, quando em 1931 ela ressurge, teremos algumas informações sugestivas:

\begin{abstract}
Um vespertino é, antes de tudo, feito possivelmente com brilho. À hora em que se oferece ao leitor, ninguém quer saber de coisas pesadas, de doutrinações, de cogitações profundas. Dele se pede o raconto do que ocorreu durante o tempo em que as solicitações da vida prática nos absorveram e nos prenderam ao trabalho. E como as cousas mais próximas são as que mais interessam, o vespertino será essencialmente local. Leve e vibrante, porque assim pede o estado de espírito de quem se cansou durante um dia de lutas. Um vespertino é a voz da cidade onde se publica. O país e o mundo interessam-lhe, mas em segundo plano. (...) Somos aliados da lavoura. No nosso programa geral, ocupa ela o primeiro parágrafo, embora não constitua, para nós, tema constante e diuturno. ${ }^{58}$
\end{abstract}

Como se pode ver, a lavoura é o principal assunto, mas não está previsto que o jornal se ocupe dela todo o tempo. O veículo pretende ser, também, uma informação leve e agradável, para não cansar o leitor com doutrinações ou notícias pesadas, e evidencia quais são os leitores que almeja atingir: aqueles que esgotam grande parcela da sua energia no trabalho diário e buscam no periódico, impresso às 16:00 horas, informação, mas desde que ela seja transmitida com descontração e leveza.

A provável camada social de um leitorado empregado, que perfazia uma labuta diária e interessado em se informar, desde que essa atividade não o consumisse em excesso, e interessado nos problemas citadinos, e que além disso não procurava no jornal informações referentes a grandes investimentos financeiros, levando-se em consideração qual seria a camada social que veria como um dos atrativos do jornal o preço de sua compra, sendo este 1/5 inferior se comparado ao do matutino da mesma empresa, nossa pesquisa concluiu que, pelas características dos personagens das crônicas e pelas informações relativas aos jornais, sugerimos que parte considerável do público leitor da Folha da Noite pertencia às classes intermediárias. Por isso, não podemos concordar por completo com Mota e Capelato quando esses autores afirmam que a Folha da Noite, ao contrário do que ocorrera na década anterior, abandonou o seu “caráter classe média” e se viu obrigada a se voltar a outro público; segundo esses historiadores,

${ }^{58}$ Folha da Noite (São Paulo), 20 de janeiro de 1931, p. 2, in: Gisela Taschner Goldenstein, op. cit., p. 46. 
Se a primeira fase da história da "Folha" se caracterizou por uma visão urbana e fiscalista, na segunda fase, com a entrada em cena do grupo de Octaviano Alves de Lima, assumirá um caráter marcadamente rural (..) sob sua direção, as Folhas se caracterizarão como “jornais da lavoura”. 59

(...) Nessa segunda fase [1931-1945] a Folha da Noite foi perdendo sua importância e não existia, da parte dos novos dirigentes, a proposta de fazer um "jornal popular". Endereçavam suas mensagens a outro tipo de público leitor, deixando de lado a anterior preocupação de se chegar às classes populares (...) Com uma tônica diversa da anterior, o jornal da nova fase vai se firmando no debate político e econômico sempre se dirigindo à classe dominante. Defende os interesses de certos setores dessa classe os cafeicultores - com os quais especialmente se preocupa.. ${ }^{60}$.

${ }^{59}$ Carlos Guilherme da Mota \& Maria Helena Capelato, op. cit., p.55.

${ }^{60}$ Idem, ibidem, p. 65. 


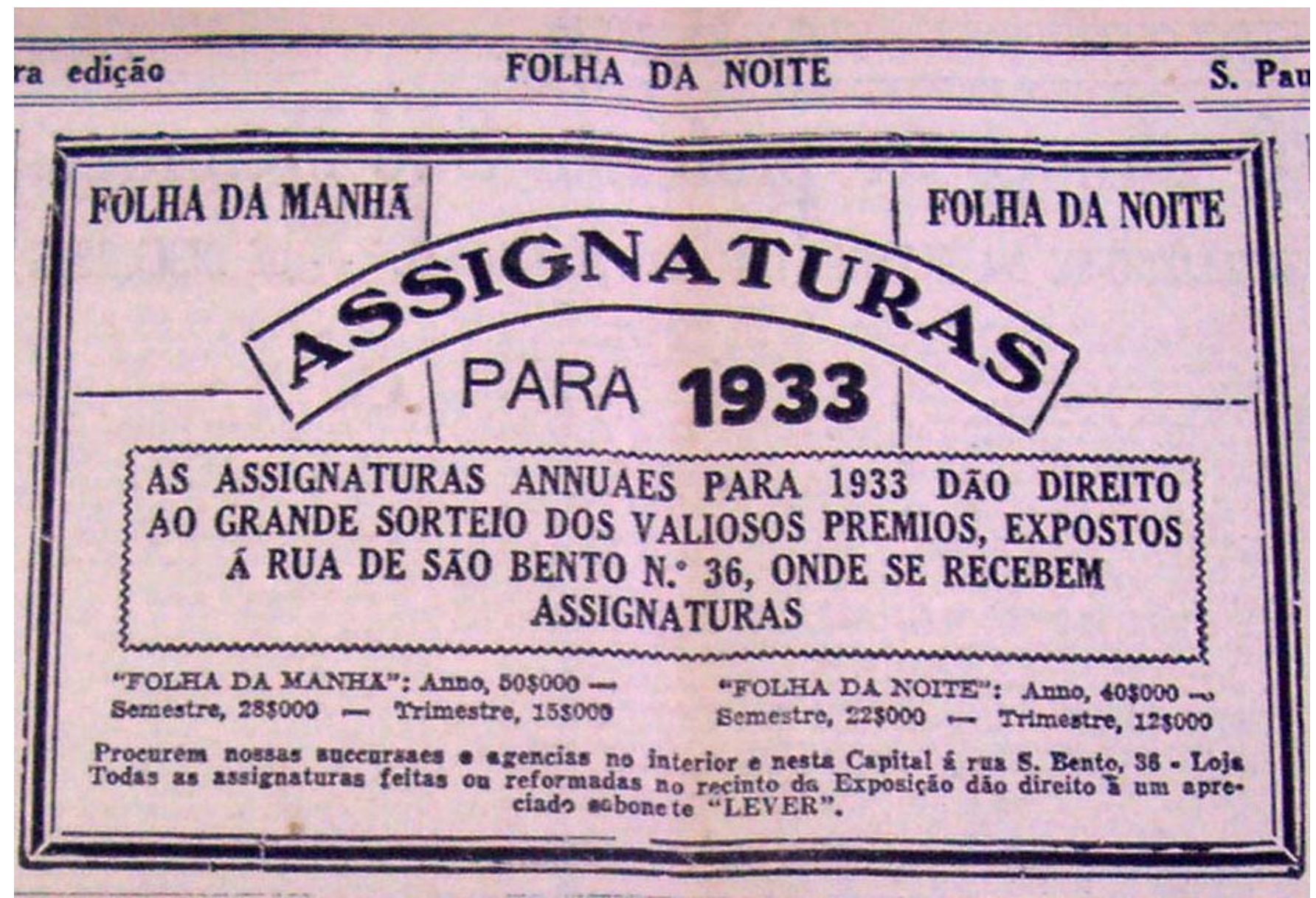

Fig. 2. Folha da Noite (São Paulo), 06/02/1933, p. 6.

“ASSIGNATURAS para 1933

'FOLHA DA MANHÃ': Anno, 50\$000 - Semestre, 28\$000 - Trimestre, 15\$000.

'FOLHA DA NOITE': Anno, 40\$000 - Semestre, 22\$000 - Trimestre, 12\$000.”

Hemeroteca do Arquivo do Estado de São Paulo - AE/SP. 
Certamente, o jornal procurou disseminar as idéias político-econômicas liberais, que eram a tônica da Empresa Folha da Manhã. Entretanto, se observarmos os planos de apresentação das mensagens do vespertino e a sua seleção de notícias, perceberemos que eles não são iguais aos da Folha da Manhã; há diferenças consideráveis. Talvez uma parcela do público leitor do vespertino pertencesse à elite paulista, mas, ao que nossa pesquisa indica, esta não constituía a maioria.

O outro aspecto a ser levado em conta, quando se pensa na distinção dos públicos leitores das Folhas, diz respeito às nossas próprias fontes principais. Atentamos para o grande prestígio que a literatura de Belmonte desfrutava à época por meio da organização das mensagens no jornal. As crônicas eram publicadas na página dois, bem ao lado direito do editorial. Ademais, se elas não dessem indícios de que iriam impulsionar as vendas de um livro, dificilmente teriam sido impressas nesse formato. Entretanto, Idéas de João Ninguém foi publicado por uma das maiores editoras brasileiras à época, a José Olympio. Ela, mais as editoras “Adersen” e “Schmidt \& Ariel” confiaram abertamente nos jovens autores brasileiros, publicando-os com bastante constância ${ }^{61}$.

A aposta que a José Olympio fez no trabalho de Belmonte não foi tão arriscada assim. Dois anos antes, em junho de 1933, o artista publicara um livro de crônicas pela Companhia Editora Nacional, intitulado Assim Falou Juca Pato (aspectos divertidos de uma confusão dramática). Anunciada com freqüência nas páginas das Folhas, esta obra desencadeou, ao que parece, uma venda considerável para a época. Em setembro de 1933, segundo propaganda do jornal, já haviam sido vendidos 4/5 de 5.000 exemplares $^{62}$.

Portanto, se partirmos do pressuposto de Mota e Capelato (de que a Folha da Noite da segunda fase era dirigida estritamente à elite), o trabalho do cronista perde o sentido, pois seu provável e principal público leitor simplesmente se evaporaria. Ao analisar a literatura de Belmonte, apreendemos inúmeros “causos” que dificilmente seriam submetidos a um processo de identificação por parte da elite paulistana: o pavor do desemprego e de suas mais cruéis conseqüências, a fome, a falta de roupas adequadas e de um teto; o crescimento desordenado da cidade de São Paulo, que tornava a realização de tarefas diárias - como ir e voltar do trabalho - muito mais difícil ${ }^{63}$.

\footnotetext{
${ }^{61}$ Para maiores informações sobre o mercado editorial na década de trinta, ver Antonio Candido. “A Revolução de 30 e a cultura”, in: A Educação pela Noite - e outros ensaios. São Paulo: Editora Ática, 1989, pp. 192-193. Ver também Sérgio Miceli, op. cit., pp. 156-157.

${ }^{62}$ Folha da Manhã (São Paulo), 29/09/1933, p. 4.

63 Tomemos como exemplo a especulação dos terrenos da cidade, já predominante no princípio do século XX, o que impediu um planejamento racional de ruas e bairros, tornando São Paulo muito extensa e, muitas vezes, com bairros desconexos entre si. Ao mesmo tempo, os comércios e serviços permaneciam centralizados, o que criava dificuldades extremas de transporte e saturação dos fluxos. Ver Nicolau Sevcenko. Orfeu Extático na Metrópole. São Paulo, sociedade e cultura nos frementes anos 20. São Paulo: Companhia das Letras, 2003, p. 109.
} 
O próprio João Ninguém, personagem que se prestou para dar título ao livro de crônicas de 1935, ganhou, pelo lápis de Belmonte, uma forma imagética para ser publicado em charges e, certamente, estava longe de despertar empatia na elite paulistana. Diferentemente de Juca Pato, que nunca viveu na pobreza extrema, João Ninguém se vestia muito modestamente, sem fraque ou camisa branca. Tinha roupas remendadas, por vezes rasgadas, não era limpo e sua barba estava sempre por fazer. Calçava sapatos furados e seu grande companheiro era o magríssimo cão de nome “Jejum”. Por vezes, o personagem tinha a companhia do também desafortunado Jeca Tatu ${ }^{64}$, personagem clássico da Literatura e da Caricatura, anterior à criação de Belmonte. João Ninguém era o desocupado paupérrimo que vivia à margem da sociedade citadina, quase um mendigo.

O aspecto de pobreza, tão característico de João Ninguém, preservava a identidade clássica do homem comum como vítima da política ${ }^{65}$. O personagem se configurou como uma das imagens de homem comum que a produção de charges brasileira elaborou de fins do século XIX em diante. Assim como ele, antes e depois, Zé Povo, Jeca Tatu, Juca Pato e Zé Marmita também o representaram ${ }^{66}$. Esses personagens expressavam situações de injustiça e desrespeito a direitos básicos sofridas pelo homem comum, desprovido de poder. Daí, ser ele, nas charges, contraposto diretamente aos causadores da sua infelicidade - políticos e ricos -, e conseguir momentos de poder através do efeito humorístico de denúncia.

A imagem de João Ninguém parecia expressar os maiores temores dos trabalhadores assalariados e dos pequeno-burgueses da época: a perda de sua fonte de renda ou a queda do poder aquisitivo, que significaria a privação de produtos básicos e a perda de algum conforto. $\mathrm{O}$ personagem começou a ser publicado nas charges de Belmonte em agosto de 1934, pouco depois da eleição indireta de Getúlio Vargas. Era impresso na Folha da Noite, em média uma vez por semana, e não chegou a conquistar a visibilidade alcançada pelo Juca Pato. Veiculado pelo jornal entre agosto de 1934 e outubro do ano seguinte, e com uma única e última aparição em dezembro de 1935 (24/12), João Ninguém parece ter desaparecido subitamente do trabalho do artista.

\footnotetext{
${ }^{64}$ Belmonte foi o segundo artista a dar forma a algumas das criações literárias de Monteiro Lobato, como, por exemplo, o enfermo roceiro Jeca Tatu, também personagem de suas charges. Ademais, ele ilustrou para Lobato alguns livros da série Sítio do Picapau Amarelo: O Circo de Escavalinho (1929), Emília no País da Gramática (1934), Aritmética da Emília (1935), Memórias da Emília (1936), todos publicados pela Editora Nacional, e O Poço do Visconde (1937), pela Editora Tribunais (e posteriormente pela Nacional). O primeiro ilustrador das obras de Lobato foi Voltolino.

${ }^{65}$ Ver Marcos Silva. Caricata República. Zé Povo e o Brasil. São Paulo: Marco Zero/CNPq, 1990, em especial o capítulo I e parte do II, pp. 07-43.

${ }^{66}$ Cada um desses personagens teve suas especificidades; afinal, eles foram publicados em periódicos diferentes e em épocas diversas. Zé Povo e Juca Pato, por exemplo, oscilavam entre a pobreza e outros níveis sociais. O primeiro, junto com João Ninguém e Zé Marmita, estava comumente ligado à pobreza extrema, enquanto que Juca Pato referia-se mais às camadas médias. Jeca Tatu se diferenciou de Zé Povo por que tinha origem e ambientação rurais. Este se caracterizava como marcadamente urbano. Ver Marcos Silva. Prazer e Poder do Amigo da Onça. São Paulo: Paz e Terra, 1996, pp. 3940. Ver do mesmo autor Caricata República, op. cit.
} 
Ainda que o livro de Belmonte tenha recebido o nome Idéas de João Ninguém, o personagem não está presente em nenhuma das crônicas, nem como narrador. Elas são contadas por um narrador onipresente e onisciente (provavelmente Belmonte), que comenta até as cartas que supostamente lhe eram enviadas pelos leitores. Em suas crônicas, ele apresenta suas próprias opiniões e idéias acerca da política, da vida moderna e dos costumes.

Não encontramos nos arquivos da Empresa Folha de São Paulo o número de exemplares vendidos naquela época. O registro das vendas dos jornais pelas empresas jornalísticas é uma prática relativamente recente no Brasil e começou há, aproximadamente, quarenta ou cinqüenta anos.

O desconhecimento sobre as vendas das Folhas nos anos 30 acarretou na obscuridade referente ao número de leitores. Mas se pensarmos que a leitura é a condição que possibilita aos indivíduos a fruição de textos, e que à época a alfabetização era um indicativo de distinção social (conhecimento mais próprio das classes dominantes e também de parcelas das classes médias), podemos tentar uma aproximação do porcentual de leitores do jornal paulista se tivermos dados referentes à quantidade de pessoas alfabetizadas no estado de São Paulo. Uma pesquisa dessa natureza foi realizada em 1940 e, segundo informações do IBGE - Instituto Brasileiro de Geografia e Estatística -, havia na época 7.180.316 pessoas vivendo no estado. Dessas, apenas 3.196.556 sabiam ler e escrever, menos de $50 \%$ dos habitantes ${ }^{67}$.

Todavia, o número de pessoas alfabetizadas à época apenas vislumbra um grupo maior onde o público leitor de Belmonte estava incluído. Certamente, apenas parte desses três milhões de indivíduos eram leitores da Folha da Noite e de seu cronista. E ainda que, provavelmente, a imensa maioria dos leitores vivesse em São Paulo - pela própria identificação com o ideário do jornal e até mesmo pela maior facilidade advinda da distribuição das Folhas no seu estado de origem -, o escritor podia ter leitores em outros estados brasileiros.

Nesse sentido, afirmamos que o número de leitores da Folha da Noite continua inexato, apesar de termos tentado uma aproximação com ele por meio do referido Censo.

67 Cf. “Recenseamento Geral do Brasil - 1940”. Rio de Janeiro: IBGE, 1950, 243 p. v.18. In: Censo Demográfico: população e habitação. 


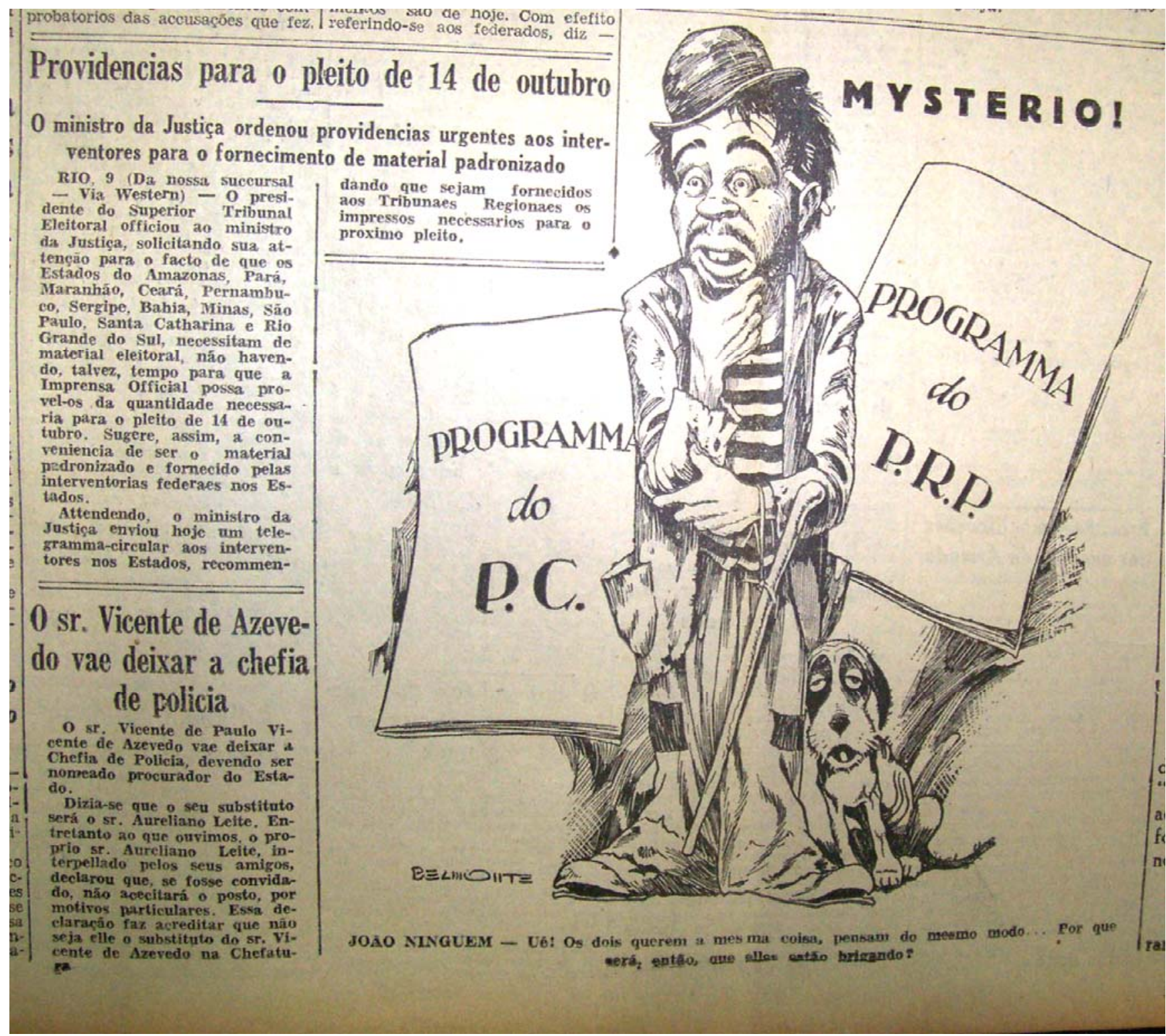

Fig. 3. Mysterio! BELMONTE.

Folha da Noite (São Paulo), 09/08/1934, p. 1.

Hemeroteca do Arquivo da Folha de São Paulo. 


\subsection{Biografia de Belmonte}

Belmonte nasceu em 1896, no dia 15 de maio, na cidade de São Paulo, onde viveu toda a vida $^{68}$. Seu nome de batismo era Benedito Bastos Barreto, posteriormente ofuscado pelo pseudônimo artístico que escolheu.

Depois de ter perdido o pai, João Carneiro Bastos Barreto, médico de profissão, quando Belmonte tinha dois anos de idade, sua família parece ter enfrentado dificuldades financeiras. Mesmo assim, a mãe de Belmonte nunca descuidou da sua educação. Ele foi matriculado na Escola Modelo, anexa à Normal, mais tarde, transferido para o Ginásio Macedo Soares e depois para o Instituto Ciências e Letras. Com o professor Henrique Geenen, estudou latim, grego e alemão, além de literatura $^{69}$. Belmonte recebeu, portanto, uma educação esmerada, própria das camadas médias mais abastadas da Primeira República.

Após concluir seus estudos no Instituto, Belmonte matriculou-se na Faculdade de Medicina da rua Brigadeiro Tobias, mas lá permaneceu por pouco tempo, pois gostava mesmo era de desenhar e escrever. Em 1914, ele conseguiu publicar pela primeira vez um desenho seu na Revista Humorística Rio Branco $^{70}$. Belmonte prosseguiu desenhando e escrevendo para revistas e jornais de tiragens mais ou menos modestas de São Paulo por mais alguns anos ${ }^{71}$.

Em fins da década de 1910, Belmonte iniciou contato com o Rio de Janeiro por meio da Revista da Semana, publicada à época como suplemento do Jornal do Brasil. Logo depois, começou a colaborar com a D. Quixote. Ao estreitar relações com editores e artistas cariocas, recebeu convite da Careta para substituir o grande caricaturista e chargista J. Carlos, em 1922, que deixou a revista para se dedicar a outros projetos. Mas o artista paulistano se recusou a mudar de São Paulo, cidade

\footnotetext{
${ }^{68}$ Cf. Ver prefácio escrito por Paulo Duarte. In: Belmonte Presente. São Paulo: Secretaria da Cultura, Ciência e Tecnologia - DACH - Comissão de Artes Plásticas, 1978, p. 01.

${ }^{69}$ Ver prefácio escrito por Leonardo Arroyo, onde ele relembra aspectos da vida de Belmonte, seu colega de trabalho na Folha da Noite. In: Belmonte. No Tempo dos Bandeirantes. Coleção Paulística, vol. XX. Edição Fac-similada. São Paulo: Governo do Estado de São Paulo, 1980, p. 09. Ver também Luís Correia de Melo. Dicionário de Autores Paulistas. São Paulo: Comissão do IV Centenário da Cidade de São Paulo - Serviço de Comemorações Culturais, 1954, p. 84.

${ }^{70}$ Ver prefácio escrito por Paulo Duarte, op. Cit., p. 01

${ }^{71}$ Revista “Alvorada” (1914), “Miscelânea” e “Zig-Zag”, ambas de 1919. Ver prefácio escrito por Paulo Duarte, op. cit., p. 01.
} 
pela qual ele tinha um apego muito forte ${ }^{72}$. Sendo assim, ele passou a colaborar a distância e eventualmente com a Careta, enviando seus trabalhos de sua urbe natal.

Casou-se com Francisca Cardoso, com quem teve uma filha, Laís Bastos Barreto. Após seu casamento, mudou-se do Bairro da Liberdade, onde nascera e vivera até então, para uma casa no Pacaembu, no número 129 da Rua Atibaia ${ }^{73}$, região despovoada e um tanto distante do centro da cidade naqueles idos de 1921-1922.

Foi Paulo Duarte ${ }^{74}$, seu amigo desde a adolescência, que o encaminhou para a Folha, onde faria carreira. Quando da fundação da Folha da Noite, em 1921, o grande caricaturista de São Paulo, Voltolino, estava adoentado. Poucos meses depois, como ele não se recuperava, o jornal passou a procurar um humorista do lápis para substituí-lo. Segundo Paulo Duarte, que na época trabalhava nesse periódico, ele mesmo falou a Olival Costa, o redator-chefe, sobre o seu amigo "Barreto”. O rapaz foi até a redação da Folha, fez o teste, foi aprovado e, pouco tempo depois, adotou o pseudônimo Belmonte. Em pouco tempo, Belmonte tornou-se tão popular em todo o país que a sua colaboração, disputada entre os proprietários de jornais e revistas, era a mais bem paga numa época em que dificilmente se vivia exclusivamente da imprensa no Brasil $^{75}$.

Na Revista do Brasil, dirigida naqueles anos iniciais da década de 20 por José Bento Monteiro Lobato, Belmonte publicou diversas de suas charges como as melhores do mês e estreitou um relacionamento de amizade, admiração e respeito com o escritor. Entre 1923 e 1926, Monteiro Lobato enviou ao artista paulistano algumas cartas de afetuosa camaradagem ${ }^{76}$. Nesta mesma década, Belmonte se aproximou bastante do criador do Sítio do Pica-Pau Amarelo e de Cassiano Ricardo, e repudiou as experiências pictóricas dos modernistas. O artista considerava-os excêntricos, denominando-os erroneamente, em algumas das charges e crônicas de sua autoria, como "futuristas". Em um artigo publicado no dia 15 de julho de $1925^{77}$, ele endereçou uma crítica ácida e um tanto ingênua à pintura de Tarsila do Amaral, e aproveitou para golpear as artes plásticas de avant-garde como um todo:

\footnotetext{
${ }^{72}$ Cf. Andréa de Araújo Nogueira. Um Juca na Cidade: representatividade do personagem criado por Belmonte na imprensa paulista (Folha da Manhã 1925-1927). São Paulo: IA-Unesp, 1999, pp. 47, 49-50. (Dissertação de Mestrado) Ver também prefácio escrito por Paulo Duarte, in: Belmonte Presente. São Paulo: Secretaria da Cultura, Ciência e Tecnologia - DACH - Comissão de Artes Plásticas, 1978, p. 03.

${ }^{73}$ Cf. Andréa de Araújo Nogueira, op. cit.

${ }^{74}$ Paulo Duarte (1899-1984) manteve uma sólida amizade com Belmonte. Duarte foi jornalista do Diário Nacional, da Folha da Noite, de O Estado de São Paulo, membro ativo do Partido Democrático (1926-1934), escritor e professor da disciplina de Pré-história da Universidade de São Paulo, entre outras atividades.

${ }^{75}$ Cf. "Vida e obra de Belmonte." Folha da Noite (São Paulo), 25 abr. 1947.

${ }^{76}$ Cf. Andréa de Araújo Nogueira, op. Cit., pp. 150-151. Ver também o site do jornal Folha de São Paulo: http://almanaque.folha.uol.com.br/belmonte.htm

${ }^{77}$ Gênios a granel!. Publicado na Folha da Manhã, 15 jul. 1925, p. 2.
} 
Incapaz de compreender o aspecto formal da obra de Tarsila, que assumiu abertamente a feição de resgate do popular e purista da cores, sob a égide da antropofagia de Oswald de Andrade, Belmonte compara a produção da artista paulista - a obra Gazo (1924) - de sua fase do Manifesto Pau-Brasil, com a de uma criança (...). A crítica de Belmonte se concentra sobre as questões de ruptura aspiradas pelos modernistas, negando os valores da pintura clássica, como a harmonia, e no fato de terem a liberdade de se autodenominarem enquanto grupo:

"No dia em que fizerem [as crianças imporem sua genialidade], os Andrades e Segalls os levarão aos píncaros da Fama e o mundo, refeito e glorioso, há de beijar-lhes as mãos sublimes!”

Apesar da crítica raivosa e com alguns elementos que lembram o artigo “A Propósito da Exposição Malfatti”, provavelmente o texto de Belmonte não tenha provocado polêmica, pois a presença de posições desfavoráveis ao movimento eram constantes no jornal da Folha. ${ }^{78}$

Além de repudiar a grande liberdade de criação dos pintores modernistas e a falta de formação acadêmica dos mesmos, suposição incorreta de sua parte, Belmonte identificava-se com os valores do nacionalismo de Monteiro Lobato e da Revista do Brasil, que defendiam uma cultura autenticamente brasileira. Nesse sentido, o autor opunha-se à imitação de valores culturais europeus por parte de artistas e intelectuais brasileiros e, sobretudo, paulistas. E para ele, os artistas plásticos modernistas configuravam-se em copiadores banais daquilo que vinha do outro lado do oceano Atlântico ${ }^{79}$.

Ao nascimento do Partido Democrático, em 1926, Belmonte divulgou-o favoravelmente nas páginas da Folha da Manhã. Em 1927, a convite de Paulo Duarte, que chefiava a redação do Diário Nacional, Belmonte começou a trabalhar para esse periódico. Além de colaborar no órgão jornalístico do Partido Democrático, Belmonte procurou apoiá-lo por meio da elaboração de propagandas visuais para as eleições estaduais de 24 de fevereiro de 1928. Belmonte retornaria às Folhas apenas no princípio de 1930, e de lá não mais sairia. Como cronista e, especialmente, como caricaturista, Belmonte “reinou” praticamente sozinho na Paulicéia dos anos de 1925 a $1940{ }^{80}$.

\footnotetext{
${ }^{78}$ O artigo “A Propósito da Exposição Malfatti”, publicado n’ O Estado de São Paulo de 20 de dezembro de 1917, foi de Monteiro Lobato, e referiu-se à exposição de Anita Malfatti, que apresentava forte influência do Expressionismo Alemão. Posteriormente, no livro Idéas de Jeca Tatu, a crítica do mesmo autor foi nomeada "Paranóia ou Mistificação?”. Cf. Andréa de Araújo Nogueira, op. Cit., pp. 65-67.

${ }^{79}$ Idem, ibidem, p. 67.

${ }^{80}$ Ver prefácio escrito por Paulo Duarte, op. Cit., p. 04. Ver ainda Herman Lima. História da Caricatura no Brasil volume IV. Rio de Janeiro: José Olympio, 1963, p. 1372.
} 
Na década de 30, o artista desempenhou a função de Diretor Artístico do suplemento dominical da Folha da Manha $\tilde{a}^{81}$. Ele ilustrava páginas inteiras, principalmente a primeira página do suplemento. O suplemento de domingo, um caderno extra de dez a doze páginas, era voltado para distrair e relaxar os leitores por meio de fragmentos seriados da literatura universal, charadas, caçapalavras, histórias em quadrinhos para adultos e crianças, piadas e desenhos, muitos desenhos. A propaganda do suplemento era publicada - invariavelmente - nos dias mais próximos do domingo, na quinta, sexta e sábado. E ela saía nos dois jornais, na Folha da Manhã e Folha da Noite. Os desenhos de autoria de Belmonte constituíam-se no cerne da propaganda.

Ele não publicava crônicas no suplemento. Mas suas ilustrações tinham qualidade e beleza excepcionais, e, em geral, se aproximavam dos padrões acadêmicos de arte, diferentemente de parte de suas caricaturas.

Belmonte também escreveu e ilustrou seus trabalhos para diversas revistas do Rio de Janeiro e de São Paulo, entre as quais Alvorada (SP), a já citada Careta, D. Quixote (RJ), Cigarra, Vida Paulista e Frou-Frou (SP).

Durante a Revolução de 1932, Belmonte elaborou charges, cartazes e pronunciou discursos radiofônicos para auxiliar a causa de São Paulo. Ele criou ainda a estampa do "bônus de guerra", que circulou como dinheiro, substituindo a moeda oficial durante o período da Revolução Constitucionalista $^{82}$. Mas não foi o único a fazer uso dos seus dotes artísticos em prol da guerra paulista; Anita Malfatti, Mário de Andrade, Monteiro Lobato, Guilherme de Almeida e Menotti Del Picchia manifestaram publicamente seu apoio aos revolucionários de julho, e trabalharam incansavelmente naquele período, criando propagandas para a mesma causa ${ }^{83}$.

Nos anos vinte e trinta, Belmonte foi o artista que elaborou visualmente a talvez mais famosa imagem do bandeirante, disseminada especialmente durante a guerra civil de $1932^{84}$ : a do homem heróico. Seus desenhos, representando indivíduos moralmente fortes, inabaláveis e serenos, másculos porque abundantemente barbudos e fisicamente rijos, contavam ainda com os seguintes detalhes: chapéus de longas abas, botas elegantes, mosquete ou arcabuz e uma longa e esguia espada de concha, lembrando mais, nesse sentido, os mosqueteiros franceses do século XVII.

81 Cf. Nelson Vainer. “Belmonte. Ao décimo aniversário do desaparecimento do grande artista.” Correio da Manhã, Rio de Janeiro, 25 de maio 1957.

${ }^{82}$ Cf. Andréa de Araújo Nogueira, op. Cit., p. 70.

${ }^{83}$ Ver Jeziel de Paula. 1932 - Imagens Construindo a História. Campinas/SP: Editora da Unicamp/Editora Unimep, 1999, p. 147. Ver também Maria Helena Capelato. O Movimento de 1932: a causa Paulista. São Paulo: Brasiliense, 1982, p. 28-29.

${ }^{84}$ Cf. Luis Fernando Cerri, NON DUCOR, DUCO: “A Ideologia da Paulistanidade e a Escola”. In: Revista Brasileira de História. São Paulo: Volume 18, número 36, 1998, p. 09. 


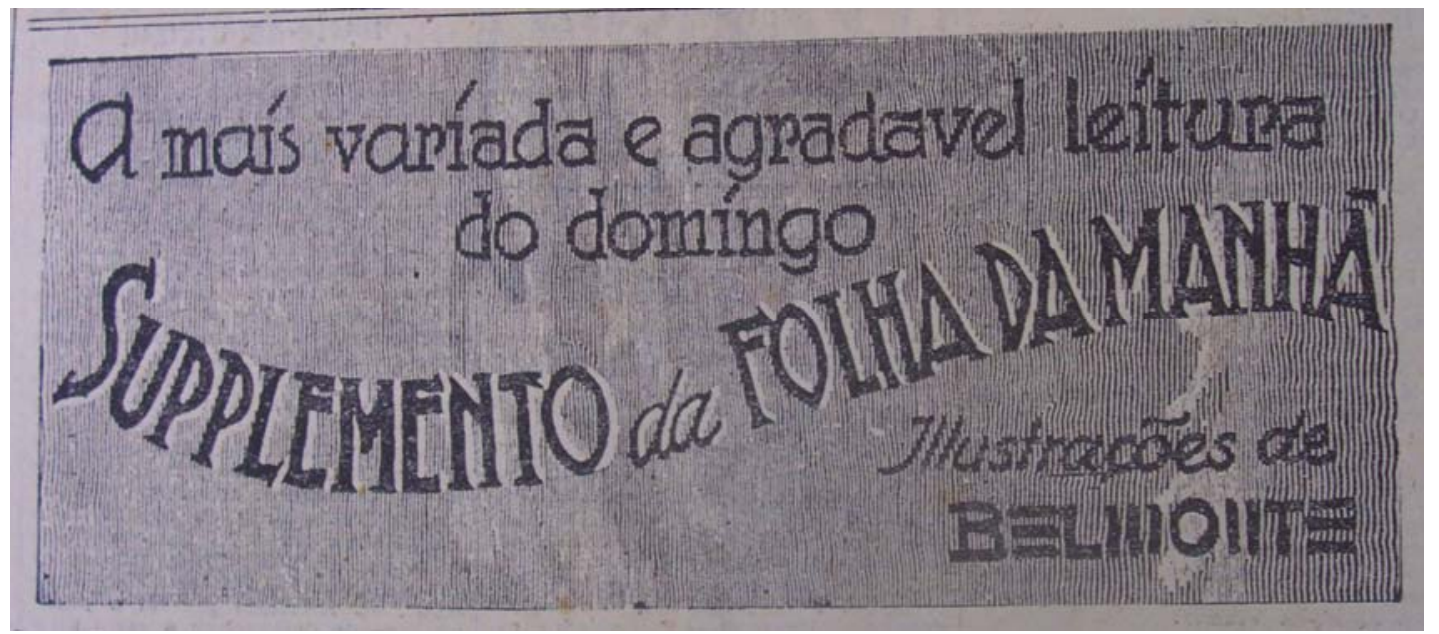

Fig. 4. Folha da Noite (São Paulo), 03/01/1933, p. 3.

Hemeroteca do Arquivo do Estado de São Paulo - AE/SP. 


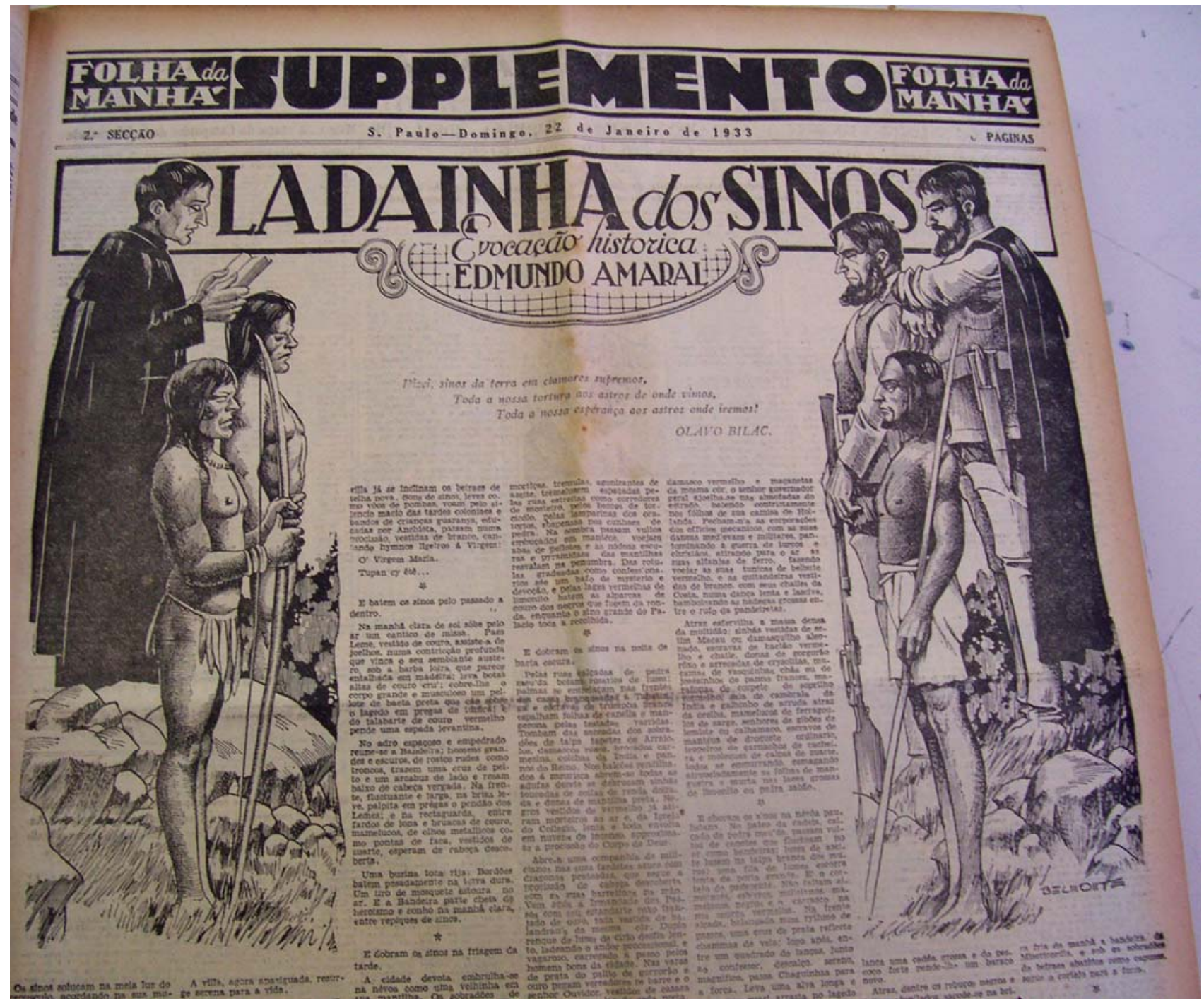

Fig. 5. Ilustração de Belmonte.

Suplemento da Folha da Manhã (São Paulo), 22/01/1933, p. 18.

Hemeroteca do Arquivo do Estado de São Paulo - AE/SP. 
Realizadas ininterruptamente por mais de vinte anos, as criações de Belmonte revelam-nos um artista erudito, dono de um conhecimento vasto e invejável ${ }^{85}$, e versado em várias linguagens artísticas. Muito provavelmente ele lia e compreendia latim, grego e alemão, pois estudou essas línguas com o professor Henrique Geenen. E como ele concluíra o Ginásio e o Instituto Ciências e Letras - admirável etapa de estudo, na época conquistada apenas pela elite e por parcela das classes médias -, provavelmente compreendia e lia também o francês, idioma comumente ensinado no processo de escolarização. Ao observar a bibliografia consultada pelo artista para a elaboração do livro No tempo dos Bandeirantes, publicado em 1939, percebemos que ele pesquisou em livros escritos em português, como também naqueles elaborados por teóricos e pesquisadores estrangeiros, e que ainda não haviam sido traduzidos para a nossa língua. Logo, para fazer a sua pesquisa, ele leu em alemão, francês e inglês.

De outro lado, Belmonte foi um intelectual cuja aparência destoava da brancura epidérmica valorizada e almejada por parcela da elite brasileira ${ }^{86}$, pois suas fotos evidenciam uma pele acentuadamente morena e cabelos bastante encaracolados, indicando uma provável ascendência mestiça.

Profundamente antifascista desde, pelo menos, a ascensão de Adolf Hitler ao poder na Alemanha, em princípio de 1933, o artista paulistano alcançou fama internacional com a eclosão da Segunda Guerra Mundial. Mussolini, Hitler, Hiroito, Churchill, Roosevelt e Stalin tornaram-se, sob a pena de Belmonte, personagens tragicômicos de charges inesquecíveis. E elas circularam por parte considerável do mundo ocidental: Estados Unidos, Argentina, Colômbia, França e Portugal, além de outros países. Revistas como ABC (Portugal), Le Rire (França), Judge (EUA) e Caras y Caretas (Argentina) reproduziram as charges de Belmonte ${ }^{87}$.

Há, ainda, uma história comentada por Leonardo Arroyo ${ }^{88}$ e Andréa de Araújo Nogueira, que contam que, no princípio de 1943, o Ministro da Propaganda da Alemanha Nazista, Josef Goebbels, atacou em seus discursos o artista pelo rádio, acusando-o de ser muito bem-pago pelos aliados. Pesquisando no acervo da Folha em busca de algum documento que informasse sobre este fato, encontramos apenas uma charge acompanhada de um curto texto de autoria de Belmonte, onde o

\footnotetext{
${ }^{85}$ Belmonte mostrava deter conhecimentos diversificados e aprofundados acerca da literatura brasileira, portuguesa, alemã, francesa e inglesa. Demonstrava conhecer razoavelmente as teorias de alguns filósofos europeus, e, por vezes, algumas das idéias de Nietzsche eram apresentadas, ainda que superficialmente, aos seus leitores. O artista era atraído, também, pelo estudo da história do Brasil e da Europa.

${ }^{86}$ Parte dela era simpática às teorias eugênicas, cujas fontes remontavam às obras de Le Bon, Gobineau, Renan, Taine $\mathrm{e}$ La Pouge.

${ }^{87}$ Cf. prefácio escrito por Leonardo Arroyo, op. Cit., p. 09-16 e, ainda, a biografia que consta no texto Belmonte, o criador do Juca Pato. In: http://almanaque.folha.uol.com.br/belmonte.htm

${ }^{88}$ Cf. Leonardo Arroyo, op. cit., p. 12. Ver também Andréa de Araújo Nogueira, op. cit., p. 70.
} 
Juca Pato agradece a Goebbels por ele ter feito propaganda gratuita do nome e trabalho do seu criador - um combatente do lápis que, desde 1932, mantinha-se em vigília contra o Nazi-fascismo.

Em 1942, o artista foi convidado por Cândido da Mota Filho para chefiar a Assistência Técnica de Festejos Populares. Nesse período, ele organizou e conduziu um minucioso trabalho de recuperação e restabelecimento das Festas do Divino ${ }^{89}$.

Belmonte não alcançou a velhice. Na cidade de São Paulo, madrugada do dia 19 de abril de 1947, com cinqüenta e um anos incompletos, ele foi liquidado por uma moléstia pulmonar ${ }^{90}$ que o consumia havia vários anos.

\footnotetext{
${ }^{89}$ Cf. Andréa de Araújo Nogueira, op. Cit., p. 70.

${ }^{90}$ Consta no site do jornal Folha de São Paulo - http://almanaque.folha.uol.com.br/belmonte.htm - que ele morreu de tuberculose. Mas a historiadora Andréa de Araújo Nogueira, baseada em entrevista realizada no dia 10 de agosto de 1996 com a filha do artista (que era adolescente quando perdeu o pai), afirma que o motivo da morte foi asma. Cf. NOGUEIRA, op. Cit., páginas 70 e 146.
} 


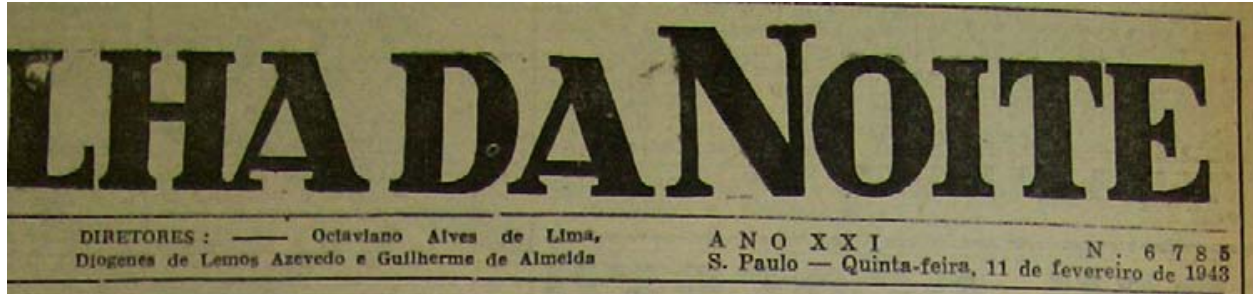

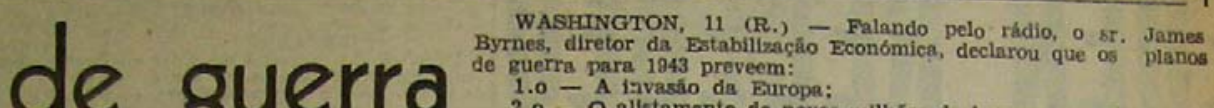

2.0 - O allstamento de novos millhóes de homens nas forças ar-

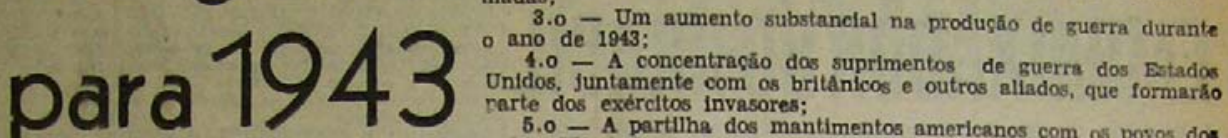
5.0 - A partilha dos mantimentos americanos com os povos dos 5.0 - A partilha dos mantimes libertados.
pastes

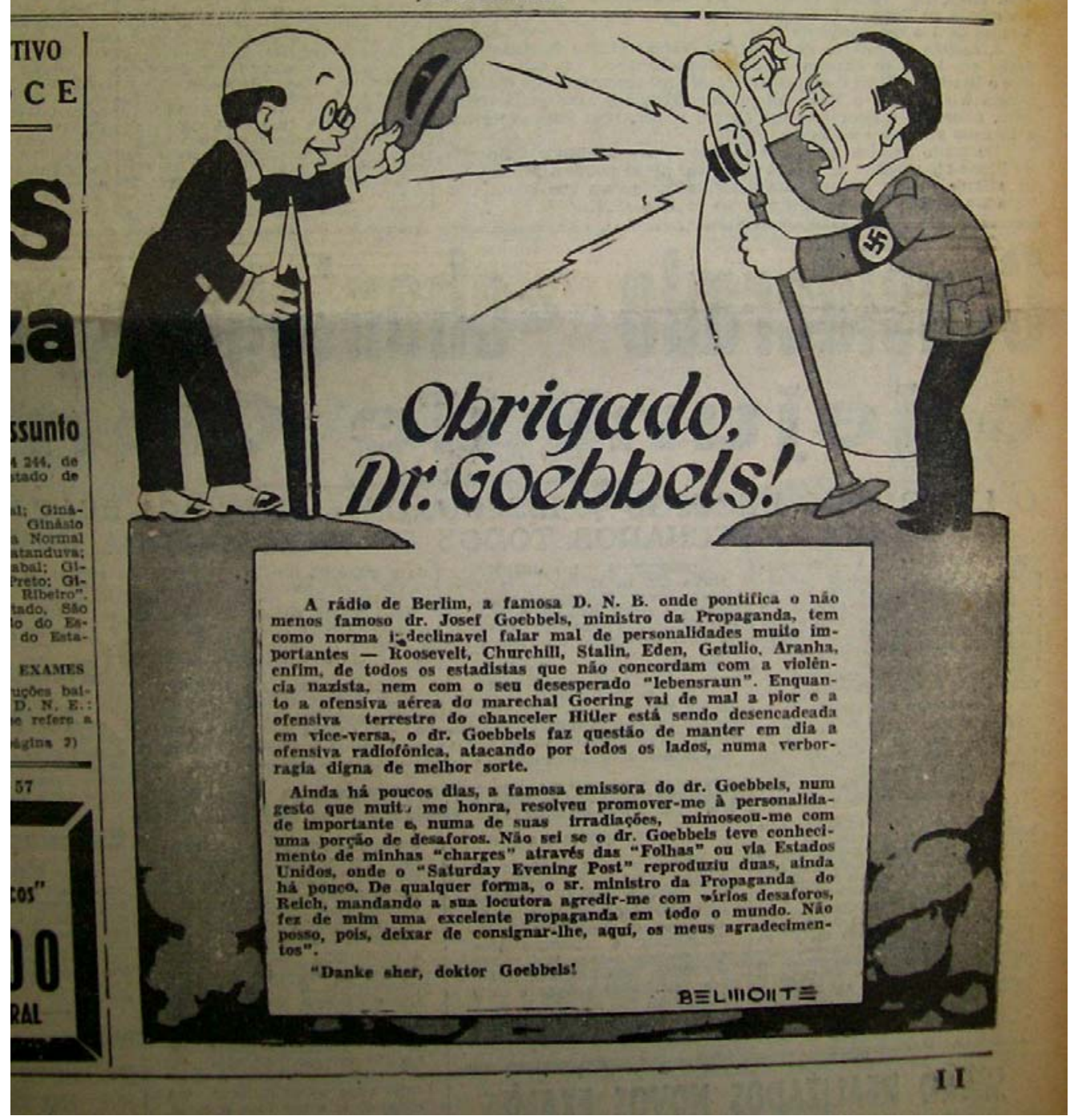

Fig. 6. Obrigada, Dr. Goebbels! BELMONTE.

Folha da Noite (São Paulo), 11/02/1943, p. 1.

Hemeroteca do Arquivo da Folha de São Paulo. 


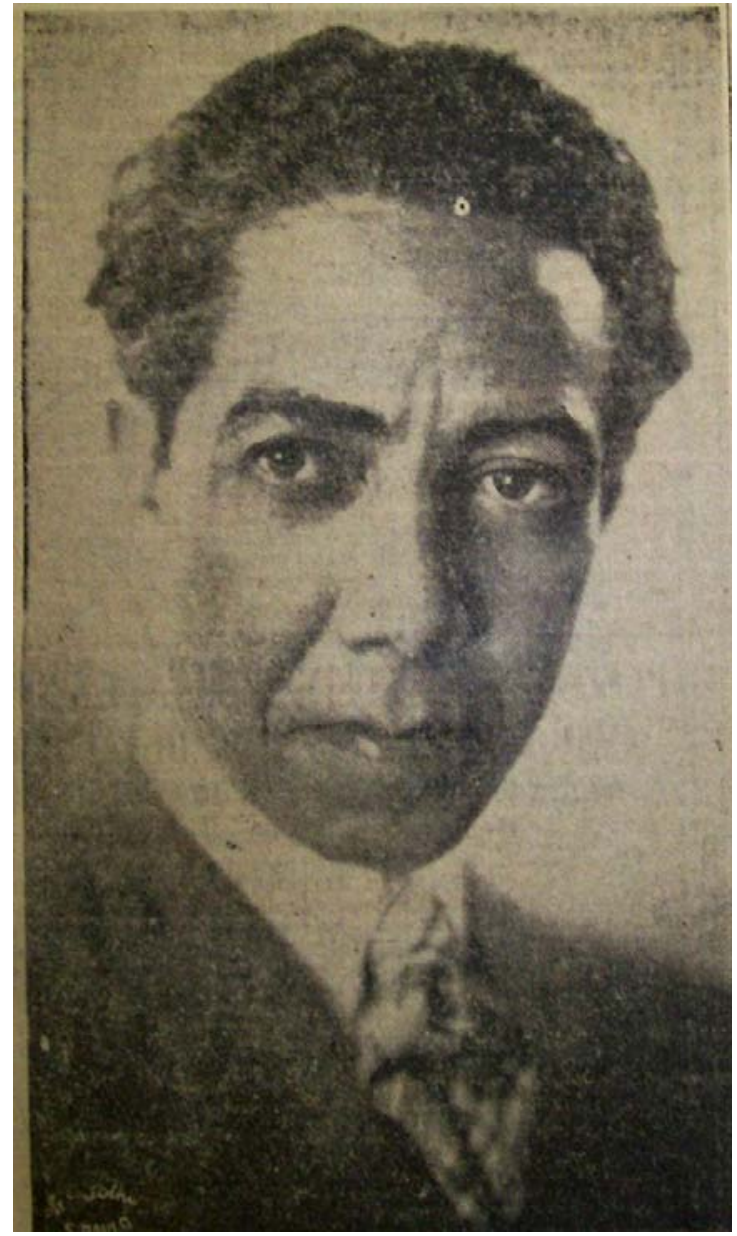

Fig. 7. Fotografia de Belmonte.

Folha da Manhã (São Paulo), 20/04/1947, p. 1.

Hemeroteca do Arquivo da Folha de São Paulo. 


\section{1930-1934: Impressões sobre o "Novo"}

Participavam da Aliança Liberal, no final dos anos 1920 (grupo opositor aos desdobramentos políticos da Primeira República), os membros das elites de Minas Gerais, Rio Grande do Sul e Paraíba e os militares rebeldes, grande parte deles representante do pequeno oficialato. Também a compunha a elite dissidente de São Paulo, encabeçada pelo Partido Democrático (PD), que via suas chances de alcançar o poder estadual (e federal) por meio de um pleito democrático se esvaírem, por causa do predomínio absoluto do Partido Republicano Paulista (PRP), mantido à custa de fraudes e intimidações.

No entanto, os liberais do PRP e do PD não possuíam diferenças acentuadas em seu ideário econômico e político, tendo sido o desacordo entre eles desencadeado principalmente por causa do predomínio político do PRP. Ambos os partidos eram compostos e liderados pela elite paulista, e o PD tinha ainda o apoio das classes médias (mas apenas uma parcela ínfima do operariado era agremiada ao $\mathrm{PD}^{91}$ ). Segundo o historiador Joseph Love, tanto o PRP como o PD professavam a defesa dos ideais liberais do século XIX. Defendiam as liberdades do indivíduo, eram favoráveis a uma intervenção bastante moderada do Estado na economia (exceto pela sustentação do setor cafeeiro, que ambos os partidos endossavam) e não abriam mão de um elevado grau de autonomia para cada membro (estado) da Federação ${ }^{92}$.

Para a historiadora Maria Lígia Coelho Prado, o Partido Democrático “...foi, sem dúvida, um partido conservador, com uma plataforma ideológica embasada nos fundamentos liberais - a legitimidade da propriedade, a igualdade jurídica, o individualismo e a liberdade (de associação e expressão)" ${ }^{93}$.

Após os primeiros meses de governo revolucionário (1930-31), os paulistas filiados ou favoráveis ao Partido Democrático, que haviam apoiado a vitoriosa investida da Aliança Liberal contra a Primeira República, sentiam-se decepcionados, pois não obtiveram um interventor civil e paulista, e os discursos dos políticos de posse do poder sempre adiavam a retomada de um regime legal para o Brasil ${ }^{94}$. Além do mais, apesar das discórdias existentes entre PRP e PD, os partidários do primeiro eram, na maioria das vezes, parentes de segundo ou primeiro grau dos democráticos ${ }^{95}$ e

\footnotetext{
${ }^{91}$ Cf. Maria Lígia Coelho Prado, A Democracia Ilustrada (O Partido Democrático em São Paulo, 1926-1934). São Paulo: Editora Ática, 1986, p. 166.

${ }^{92}$ Cf. Joseph Love. A Locomotiva: São Paulo na Federação Brasileira - 1889-1937. Rio de Janeiro: Paz e Terra, 1982, p. 194.

${ }^{93}$ Cf. Maria Lígia Coelho Prado, op. cit., p. 175.

${ }^{94}$ Cf. Jeziel de Paula. 1932 - Imagens Construindo a História. Campinas/SP: Editora da Unicamp/Editora Unimep, 1999, p. 65.

${ }^{95}$ Cf. Joseph Love, op. cit.
} 
tinham os melhores cargos políticos do rico estado cafeeiro. Parcelas destes bons cargos e empregos lhes foram arrebatados e ocupados por homens exógenos à elite paulista e a São Paulo. Isto enfureceu os democráticos, certos de que os cargos deveriam lhes pertencer - “filhos legítimos” que eram da terra paulista -, mas nunca aos Tenentes “forasteiros” que tinham chegado, havia poucos meses, das mais distantes regiões do país, em geral do Nordeste e do extremo Sul.

Para a elite paulista, no âmbito das finanças estaduais, São Paulo também se viu lesada com a Revolução de 1930, pois sua autonomia econômica foi cerceada. Uma parcela do imposto de exportação do café, que o estado de São Paulo arrecadava integralmente na Primeira República, foi repassada para o governo federal. Este criou novos impostos e, em fevereiro de 1931, foi "cobrada uma taxa sobre o pé de café e o Governo passa a reter para si 20\% do café exportado”. ${ }^{96}$

Outra taxa imposta após 1931 e que recaiu sobre São Paulo dizia respeito às estradas paulistas, que não mais poderiam isentar de frete o açúcar do estado, de sorte que o açúcar nordestino passaria a ser favorecido. Esta medida foi interpretada pelos editoriais do Diário Nacional, órgão de imprensa do Partido Democrático, “...como ajudando a atrasar a economia paulista em favor das outras regiões. A perda da hegemonia política mostra-se sempre associada à perda dos privilégios econômicos" ${ }^{\text {97 }}$. O que se configurava em um roubo, na concepção dos paulistas da época, era, na verdade, o início de um processo de centralização governamental ${ }^{98}$.

De qualquer forma, esses acontecimentos deram origem à idéia de que o estado "bandeirante" terminara enganado e roubado por seus pares, que, por inveja e comodismo, objetivavam sugá-lo impiedosamente e empobrecê-lo. Os paulistas se colocavam incessantemente como vítimas, ludibriados e traídos pelos políticos revolucionários de outros estados e por militares insubordinados. $\mathrm{Na}$ verdade, os cafeicultores e industriais paulistas não aceitaram a perda da hegemonia política e econômica de São Paulo, e esta é a principal explicação para a eclosão da Revolução Paulista de 1932.

Todo este amálgama de decepções forneceu munição ideológica para o empreendimento da Revolução Constitucionalista, empolgada, sobretudo, pelo Partido Democrático de S. Paulo, que tinha entre seus filiados fazendeiros, industriais, banqueiros, comerciantes, funcionários públicos e profissionais liberais (o que, aliás, não diferia muito da composição do PRP. Cf. Maria Lígia Prado,

\footnotetext{
${ }^{96}$ Cf. Vavy Pacheco Borges. Getúlio Vargas e a Oligarquia Paulista: história de uma esperança e muitos desenganos. São Paulo: Editora Brasiliense, 1979, p. 143.

${ }^{97}$ Idem, ibidem, p. 147.

98 Atualmente, com o devido distanciamento histórico e baseados em pesquisas, sabemos que, durante os anos 30, o governo federal deu atenção à cafeicultura, não a desamparando sob as instabilidades financeiras da época. O Estado do Brasil procurou salvar da bancarrota parte dos grandes produtores de café. Cf. Joseph Love, op. Cit., p. 360, e também Edgard Carone, op. Cit., p. 29.
} 
1986, p. 20). Após a derrota da guerra de 1932, os sentimentos de injustiça e desencanto dos paulistas aumentaram, sobretudo entre as classes médias do estado. Estas adotaram grande parte do ideário das elites paulistas: industriais, fazendeiros e, sobretudo, cafeicultores. Sendo assim, também propalavam a extraordinária valorização do ser paulista, concomitante à crença de que, após 1930, sua gente fora roubada e vilipendiada por outros estados brasileiros e pela “dictadura” getulista.

Afinal, até então, os orgulhosos paulistanos e paulistas sentiam-se, em certa medida, os membros mais dignos e capazes da Federação do Brasil. Em fins da década de vinte,

(...) Poucos paulistas educados tinham qualquer dúvida de que sua psicologia coletiva fora herdada dos bandeirantes, e a maioria dos autores e apologistas enfatizavam os aspectos positivos: o bandeirante havia expandido a fronteira; havia posto sua energia a serviço de fins produtivos; havia percebido oportunidades e tirado bom proveito delas; havia apontado o caminho do futuro à nação brasileira. Cabia a seus descendentes modernos aceitar o destino de liderarem o país. ${ }^{99}$

Nessa mesma época, os paulistas se referiam a sua região como uma potente locomotiva que puxava vinte vagões de carga vazios, os outros estados brasileiros ${ }^{100}$. Todas essas idéias de liderança, riqueza e capacidade empreendedora do paulista vinham a corroborar seu sentimento de superioridade.

Uma incipiente concepção favorável da condição de paulista surgiu ainda no século XVIII, quando Pedro Taques escreveu a Nobiliarquia Paulistana, procurando ligar as famílias do Planalto de Piratininga aos nomes de nobreza. Pedro Taques não só qualificou aquela gente como “valorosa”, como também sublinhou seu aspecto ousado, guerreiro e conquistador ${ }^{101}$. Nas últimas décadas do século XIX e início do XX, a elite paulista republicana resgatou essas idéias e modernizou-as para a afirmação do seu grupo social em ascensão, graças à riqueza sustentada pela cafeicultura. Elas prestaram-se como justificativa dessa mesma elite para o predomínio político sobre a Federação Brasileira durante a Primeira República ${ }^{102}$.

A partir do advento da República e da federalização, o estado de São Paulo começou a estimular uma produção historiográfica que privilegiasse os feitos gloriosos da gente paulista. O auge do culto a São Paulo ocorreu entre as décadas de 1910 a 1930: a publicação das Atas da Câmara da

\footnotetext{
99 Joseph Love, op. cit., p. 107.

${ }^{100}$ Ver Richard Morse, op. cit., p. 325.

${ }^{101}$ Ver Antonio Candido, op.cit., pp. 130-133. Ver Kátia Abud. O Sangue Intimorato e as Nobilíssimas Tradições (a construção de um símbolo paulista: o Bandeirante). São Paulo: DH-FFLCH-USP, 1985, pp. 76 e 79 . Ver também Luis Fernando Cerri, op. Cit., p. 03.

${ }^{102}$ Ver Kátia Abud, op. Cit., pp. 132-133 e 140.
} 
Vila de São Paulo pelo governador Washington Luis (1914), o redimensionamento do Museu Paulista (1922) $)^{103}$, a comemoração oficial do Centenário da Independência do Brasil e os livros sobre as glórias dos bandeirantes, de autoria de Afonso d’Escragnolle Taunay (1920 e 21), Alfredo Ellis Jr. (1922 e 1926) e José de Alcântara Machado (1929), visando a afirmar São Paulo como local privilegiado para o desenrolar dos acontecimentos históricos brasileiros, salientam os esforços nesse sentido ${ }^{104}$. Os paulistas figuravam como mais organizados, ousados e trabalhadores do que os outros brasileiros. A concepção de um grande estado que orientava todo o restante do país estava em conformidade, alegoricamente, com o papel de um irmão bem mais velho que orienta a mão das crianças pequenas enquanto elas ensaiam seus primeiros rabiscos no aprendizado do abecedário. Indubitavelmente, os paulistanos e paulistas se viam como líderes de uma coletividade de estados federativos que se configurava como "imatura”, pouco desenvolvida ${ }^{105}$ e que, portanto, precisava da sua orientação.

Ou seja, concomitante ao extraordinário desenvolvimento econômico e urbano da região ${ }^{106}$ nos séculos XIX e XX, foram propaladas diversas “tradições” para São Paulo e seus habitantes, e parte delas eram reformulações de idéias e acontecimentos de outrora. Essas "tradições" inventadas ${ }^{107}$ (ou melhor, reinventadas) formaram a ideologia da paulistanidade, cristalizando-se em mitos: por exemplo, no mito dos bandeirantes dos séculos XVI ao XVIII como modelo de valentia e tenacidade e no da comunidade paulista imaginada como uma espécie de entidade personificada, que

\footnotetext{
${ }^{103}$ Affonso d’Escragnolle Taunay, Diretor do Museu Paulista a partir de 1917, foi o responsável pelo redimensionamento dessa instituição, cujo perfil era, até então, o de centro de pesquisas no campo da História Natural. Ao assumir, Taunay preocupou-se em formar coleções de documentos históricos, notadamente referentes à História de São Paulo. Para as comemorações do I $^{\circ}$ Centenário da Independência do Brasil, em 1922, houve a inauguração da Seção de História Nacional. Em setembro desse ano o museu foi reaberto após uma reforma que ampliou consideravelmente o número de suas salas de exposição, e a afluência de visitantes foi colossal. Para maiores informações, ver os sites

www.usp.br/prc/catalogomuseus/portugues/mp_apresentacao.htm e http://www.mp.usp.br/formacao.htm.

104 Taunay e Alcântara Machado foram mais foram mais que ideólogos da paulistanidade. Em seus livros, existem elementos de uma História que abrange ações coletivas e uma atenção para o dia a dia como História. E a Cultura Material já se esboça como referência para a pesquisa.

${ }^{105}$ Cf. Luis Fernando Cerri, op. Cit. Ver também Danilo Zioni Ferretti. A Construção da Paulistanidade. Identidade, Historiografia e Política em São Paulo (1856-1930). São Paulo: DH-FFLCH-USP, 2004. (Tese de Doutorado)

106 Joseph Love considera que nas primeiras décadas do século XX (pelo menos até o advento do Estado Novo), a palavra região era praticamente um sinônimo de Estado - unidade federativa. Vejamos como ele entende e define região: "Parte de uma unidade maior e interdependente com outras regiões que constituem, com ela, a unidade maior; coisa localizada geograficamente, dimensionada, e politicamente definida; unidade composta de subunidades (subregiões) contíguas; capaz de gerar fidelidades, devoção, apego nos seus habitantes, embora variáveis no tempo, em importância e intensidade; capaz de inspirar também uma lealdade subordinada à unidade maior, a União (pelo menos nominalmente) entre os diversos setores politicamente eficazes da população regional”. Ver Joseph Love, op. cit., p. 11.

107 Sobre o conceito de tradições inventadas, ver: Eric Hobsbawm e Terence Ranger. A Invenção das Tradições. Rio de Janeiro: Paz e Terra, 1984. Segundo os autores, "Por 'tradição inventada' entende-se um conjunto de práticas, normalmente reguladas por regras tácita ou abertamente aceitas; tais práticas, de natureza ritual ou simbólica, visam inculcar certos valores e normas de comportamento através da repetição, o que implica, automaticamente, uma continuidade em relação ao passado. Aliás, sempre que possível, tenta-se estabelecer continuidade com um passado histórico apropriado" (p. 09).
} 
representava todo o Estado como “um só homem” ${ }^{108}$, e cujas qualidades eram a liderança, a ousadia, o empreendedorismo e o apego ao trabalho. Esses mitos se fixaram no imaginário de parcela considerável dos habitantes da região.

Portanto, essas tradições inventadas formaram a ideologia da paulistanidade ${ }^{109}$ e se cristalizaram como mito entre fins do século XIX e nas primeiras décadas do XX. A ideologia da paulistanidade sustentava o sentimento de superioridade dos paulistas perante os brasileiros de outras regiões e justificava o predomínio político e econômico da elite cafeeira de São Paulo sobre o país.

Consideramos o mito uma leitura imaginária que uma sociedade faz de si mesma com o objetivo de se (re)definir e de se compreender. Sustentando-nos na reflexão de Raoul Girardet, em Mitos e Mitologias Políticas, podemos afirmar que nem sempre o mito permanece como mentira absoluta, pois ele seduz as consciências e empolga as ações humanas, tornando-se, desse modo, parte da História.

Ele é o impulso psicológico, a inspiração ideal, que pode conduzir para o bem ou para o mal, mas que é de qualquer modo indispensável. Grandes momentos de efervescência mitológica corresponderam sempre a momentos de crise, de mutação ou de ruptura. (...) quando uma sociedade não sabe mais o que ela é, a leitura imaginária é uma tentativa para redescobrir sua inteligibilidade perdida. ${ }^{110}$

Há também na ideologia da paulistanidade a idéia de uma comunidade paulista coesa, sem contradições, onde as divisões de classes permaneciam veladas; nela, praticamente todos os paulistas eram trabalhadores, responsáveis, respeitadores das leis e organizados. E, concomitantemente, não deixavam de ser independentes e ousados ${ }^{111}$. Foi nesse ambiente conflituoso dos primeiros anos da década de trinta, onde se desenrolava uma encarniçada luta pelo poder e se semeavam desafetos e amarguras entre os Revolucionários de Outubro e a elite paulista cafeicultora bruscamente alijada dele, que o nosso cronista elaborou e organizou suas palavras.

As classes sociais que predominavam no círculo de relacionamentos de Belmonte (trabalho e amizades) eram as médias, e nestas destacavam-se profissionais liberais (jornalistas, advogados, médicos) e artistas. Entre eles, a simpatia pelo Partido Democrático era pública e, por vezes, atuante: foi o caso de Paulo Duarte, Sérgio Milliet e Aureliano Leite.

\footnotetext{
${ }^{108}$ Ver Jeziel de Paula, op. cit., p. 279.

${ }^{109}$ Sobre a ideologia da paulistanidade, ver Luis Fernando Cerri, op. Cit. Ver também Danilo Zioni Ferretti, op. Cit.

${ }^{110}$ Raoul Girardet. Mitos e Mitologias Políticas. São Paulo: Companhia das letras, 1987.

Ver também Bronislaw Baczko. “Imaginação Social”. In: Ruggiero Romano (org.) Anthropos-homem. Enciclopédia Einaudi, 5. Vila da Maia: Imprensa Nacional/Casa da Moeda, 1985, pp. 297-332.

${ }^{111}$ Danilo Zioni Ferretti, op. Cit., pp. 240-365 passim.
} 
O próprio Belmonte fizera inúmeras propagandas em favor da Revolução Paulista, como já foi colocado. Lembremos também que na eleição estadual de 1928, ele se engajou na campanha, desenhando cartazes valorizadores do Partido Democrático, prontamente usados como propaganda. Além do mais, a pesquisadora Andréa de Araújo Nogueira salienta que entre os anos de 1926 e 1927, o artista usou o seu personagem mais popular da Folha da Manhã, o boneco Juca Pato, para disseminar a simpatia pelo partido entre os leitores do jornal ${ }^{112}$. Logo, nos idos de 1926-1932, a aproximação de Belmonte com o Partido Democrático é significativamente marcante. As idéias de regenerar a democracia brasileira e de investir na educação popular e pública ${ }^{113}$ atraíram o artista para suas fileiras. Entretanto, essa identificação de Belmonte com o partido parece esmorecer a partir do início dos trabalhos da Assembléia Nacional Constituinte, ainda em 1933, quando parte de seus deputados procura se aproximar de Getúlio Vargas, encetando pactos “de boa convivência” com ele.

Para Belmonte, assim como para muitos de seus conterrâneos, o novo governo possuidor da máquina administrativa traiu suas promessas iniciais, firmadas nos tempos da Aliança Liberal, quando se estabeleceu que o regime federativo de 1891 seria respeitado e se indicaria um paulista para governar o estado ${ }^{114}$. Os outros objetivos seriam moralizar as eleições e regenerar o regime republicano brasileiro e também foram colocados em segundo plano pelo novo governo após a conquista do poder.

Antes de prosseguirmos, é indispensável fazer uma pausa e explicar porque sempre escreveremos as expressões Revolução de 30 e Revolução Constitucionalista de 1932 (e os seus respectivos revolucionários) destacando com itálico a primeira palavra.

São expressões consagradas de há muito pela historiografia, usadas com freqüência e sem hesitação por historiadores de diferentes tendências. Mesmo assim, não nos sentimos confortáveis em utilizá-las sem alguma ressalva, porque compreendemos o conceito Revolução como uma profunda modificação social, e que atinge, por sua vez, a base econômica e transforma radicalmente as relações de produção.

\footnotetext{
${ }^{112}$ Cf. Andréa de Araújo Nogueira. Um Juca na Cidade: representatividade do personagem criado por Belmonte na imprensa paulista (Folha da Manhã 1925-1927). Dissertação de Mestrado apresentada ao Instituto de Artes da Universidade Estadual Paulista. São Paulo: digitado, 1999, pp. 107-113.

113 Cf. Maria Helena Capelato. Os Arautos do Liberalismo. Imprensa Paulista (1920-1945). São Paulo: Brasiliense, 1989, p. 158.

Em suas crônicas escritas entre 1933 e 1935, algumas versam sobre educação e dirigem duras críticas contra a ineficiência do governo nesta questão. Faltam prédios escolares, remuneração digna aos professores e materiais didáticos, entre outras queixas. Cf. crônicas Os professores (03/08/1933), Escolas! Escolas! (28/09/33), Analphabetismo (01/03/1934), Viva a burrice! (09/05/1934), Pedagogos Universitários (22/05/1934) e O drama escolar (30/01/1935). No período pesquisado, estes foram os escritos referentes à educação.

${ }^{114}$ Cf. Maria Helena Capelato, op. Cit., p. 183-187.
} 
Ora, nenhuma das duas revoluções abordadas nessa dissertação foi revolucionária no sentido em que compreendemos este conceito. Ainda que os governos encabeçados por Getúlio Vargas tenham empreendido mudanças políticas e econômicas significativas ${ }^{115}$, a dominação de classe e a marginalização de largas parcelas da população brasileira prosseguiram. Dessa forma, ao sermos obrigados a nos referir a uma revolução que não o foi, tomamos o cuidado de destacá-la.

Evitamos empregar a expressão República Velha, optando por Primeira República. Ocorre que, assim como Revolução de 30, República Velha foi uma expressão cunhada pelos vencedores do processo histórico, os revolucionários que ascenderam ao poder político em outubro de 1930. Portanto, em lugar de utilizarmos um termo que germinou da memória forjada pelos vencedores ${ }^{116}$, preferimos algum outro isento desse direcionamento ideológico.

\subsection{Sobre o Humor}

Mas é necessário fazer ainda uma segunda pausa na nossa exposição do panorama político brasileiro do início da década de trinta: antes de abordarmos quaisquer crônicas, urge discorrer sobre a metodologia empregada para a compreensão do humor. Como temos por objetivo principal a análise da literatura humorística de Belmonte, apresentamos a seguir algumas obras teóricas que versam sobre o riso e que nos auxiliaram valiosamente na orientação da análise.

Nossa metodologia para a análise das crônicas se sustenta no estudo de alguns teóricos do riso. Optamos por aqueles que escreveram a partir do final do século XIX. Afinal, antes dessa época, o riso era costumeiramente visto sob dois prismas não muito lisonjeiros: um primeiro, predominante desde a Antiguidade Clássica e defendido por Aristóteles, Platão e Cícero, segregava teoricamente o cômico como indesejável, inferior ${ }^{117}$; e um segundo, elaborado especialmente pelos teóricos ligados ao Romantismo, subdividia o riso em “vulgar” e “elevado”. Aspectos desta última visão do riso

\footnotetext{
${ }^{115}$ Como se utilizar politicamente dos trabalhadores urbanos (populismo) e investir maciçamente na industrialização.

116 Cf. Carlos Alberto Vesentini. A Teia do Fato: uma proposta de estudo sobre a memória histórica. São Paulo: HUCITEC, 1997.

117 Entretanto, ao mesmo tempo, o cômico fez parte do arsenal da retórica, direcionado especialmente para a desqualificação do oponente. Fábio Quintiliano, um grande nome nos estudos da retórica antiga, informa que filósofos e políticos da antiguidade greco-romana fizeram uso do cômico para alcançar o objetivo citado. Mas o autor adverte que o uso dele é profundamente complicado, pois, caso o cômico resvale para a grosseria ou para a brutalidade, ele termina por causar repulsa e indignação nos ouvintes, colocando-os contra o pronunciante (p.361). Além do mais, o que torna sobretudo difícil o uso do risível para se sobressair, é que para isso não há aulas e nem exercícios (p.333). Ver em Fábio Quintiliano. Institution Oratoire (II - Livres IV-VI). Texte revu et traduit avec introduction et notes par Henri Bornecque. Paris: Librarie Garnier Fréres [s/d].
} 
predominaram no Brasil durante quase todo o século XIX ${ }^{118}$. O riso "vulgar” era o "mau” riso, que rebaixava a imagem de alguém, muitas vezes associado ao erótico ou ao obsceno. Já o riso "elevado" era chamado de riso “bom”, porque saudável e não-ofensivo, ou seja, não degradava o objeto risível. Os autores que orientam a nossa pesquisa romperam com essas interpretações tradicionais e bipolares do cômico.

Um autor que nos parece profundamente pertinente é Vladimir Propp, estudioso ligado ao formalismo russo. Ele reuniu e analisou exemplos literários como Gogol e Tchekhov para poder criar uma teoria sobre a comicidade. Propp concluiu que o cômico possui sutis diferenças em seus aspectos, que levam a diferentes "tipos” de riso, sendo imprópria a tradicional separação entre "vulgar" e "elevado". Propp sistematizou a comicidade em alguns tipos: o riso de zombaria, predominante na natureza humana, o riso bom, o maldoso e cínico, o ritual e o imoderado. ${ }^{119}$ Outro aspecto importante foi o fato de Propp ter conceituado de modo claro e didático o que ele chama de “instrumentos lingüísticos da comicidade”, tão preciosos para o pesquisador desse gênero literário. Dentre eles, Propp deu destaque especial à ironia e à paródia ${ }^{120}$.

Ao refletir sobre a obra de Vladimir Propp, acreditamos que seja de grande importância para a nossa pesquisa a sua teoria de que o riso é desencadeado pelo desvelamento de diversos aspectos da realidade:

O estudo dos fatos mostra que o riso que zomba nasce sempre do desmascaramento de defeitos da vida interior, espiritual, do homem. Esses defeitos referem-se ao âmbito dos princípios morais, dos impulsos da vontade e das operações intelectuais (...) Podemos expressar a fórmula geral da teoria do cômico nestes termos: nós rimos quando em nossa consciência os princípios positivos do homem são obscurecidos pela descoberta repentina de defeitos ocultos, que se revelam por trás dos invólucros dos dados físicos, exteriores. ${ }^{121}$

Peguemos como referência a esta teoria de V. Propp a crônica É Prohibido Casar!, publicada na Folha da Noite em março de 1934, em que Belmonte comenta a atitude do interventor do Rio

\footnotetext{
${ }^{118}$ É necessário observar que o estereótipo do "bom riso" e do "mau riso" permaneceu arraigado na cultura ocidental até o século XIX. No Brasil, ele começou ser dissipado no final desse século, aproximadamente no último quartel dele, durante a crise do Império. Ver Elias Thomé Saliba. Raízes do Riso. A representação humorística na história brasileira: da Belle Époque aos primeiros tempos do rádio. São Paulo: Companhia das Letras, 2002, p. 43-58 passim.

${ }^{119}$ Vladimir Propp. Comicidade e Riso. São Paulo: Editora Ática, 1992.

${ }^{120}$ Idem, idibem,, pp. 84-87 e 119-133. Para uma melhor compreensão desses recursos cômicos, ver também Mikhail Bakhtin. A Cultura Popular na Idade Média e no Renascimento. O Contexto de François Rabelais. São Paulo/ Brasília: Edunb/Hucitec, 1996, pp. 67, 139, 165-167.

${ }^{121}$ Vladimir Propp, op. cit., p. 175.
} 
Grande do Norte, que instituíra naquele ano um decreto impedindo as professoras daquele estado de contrair matrimônio. Nessa crônica, o artista paulistano compara o governo potiguar com o da Turquia, que pouco antes havia proibido aos professores de se casarem com suas alunas. Acompanhemos a escrita ágil e zombeteira de Belmonte:

\begin{abstract}
É verdade que, se por um lado, o governo do Rio Grande do Norte foi mais liberal, por outro lado foi mais arbitrário. Com effeito, o governo turco não admitte que o professor ‘pense’ em contrahir matrimônio. Já o governador brasileiro admitte que os pedagogos pensem em casar-se; há no Norte, nesse ponto, inteira liberdade de pensamento. O que elle não admitte é que os pedagogos se casem. Mas se, na Turquia, os professores podem contrahir matrimônio, desde que não o façam com qualquer de suas alumnas, no Brasil isso não é possível de ser realizado com ninguém. Na capitania do norte prohibiu-se, pura e simplesmente, o casório - seja lá com quem for (...) O certo, porém, é que, multiplicando-se ou não, o Brasil se mostra eminentemente liberal, eis que permitte ás suas professoras do norte o direito de 'pensar' em casamento. A coacção é puramente material, como se vê, porque as professoras nordestinas poderão soltar as rédeas da imaginação em devaneios lyricos, sonhando com 'elle', soffrendo por 'elle' pensando 'nelle'.... ${ }^{122}$ [grifos nossos]
\end{abstract}

A ironia destacada nas frases sublinhadas foi um importante recurso lingüístico empregado por Belmonte para o desvelamento da política brasileira e, conseqüentemente, para a manifestação do riso $^{123}$. Na citação acima, as palavras grifadas orientam nossa percepção para o contrário do que elas afirmam: há, no caso das professoras, é certo, liberdade para devanear à vontade, mas não para decidir sobre suas vidas, que é o que realmente importa. Esta cômica e aparentemente ingênua história das mestras proibidas de se casar desmascara a sociedade brasileira do período: segundo Belmonte, ela era oprimida pelos desmandos dos “revolucionários” que tiveram oportunidade de ascender ao poder com a instauração do Governo Provisório de Getúlio Vargas. Ademais, se a primeira frase do trecho citado afirma que “...se por um lado, o governo do Rio Grande do Norte foi mais liberal, por outro lado foi mais arbitrário...”, o discorrer da crônica desacredita essa afirmação de caráter ambíguo e informa aos leitores que, comparativamente, o governo brasileiro era infinitamente

\footnotetext{
${ }^{122}$.Belmonte. Idéas de João Ninguém. Rio de Janeiro: José Olympio, 1935, p. 24-25.

${ }^{123}$ Vejamos a definição de ironia oferecida pelo teórico russo: “Diz-se algo positivo, pretendendo, ao contrário, expressar algo negativo, oposto ao que foi dito. A ironia revela assim alegoricamente os defeitos daquele (ou daquilo) de que se fala. Ela constitui um dos aspectos da zombaria e nisto está sua comicidade. O fato de o defeito vir a ser definido por meio da qualidade que se lhe opõe, coloca em evidência e realça o próprio defeito”. Ver Vladimir Propp, op. cit., p. 125.
} 
mais autoritário: “...se nós olhássemos em torno de nós, notaríamos que o governo turco, perto dos governichos brasileiros, é muito menos do que um pinto.”124

Após esclarecer alguns aspectos interessantes da teoria de Vladimir Propp, e de que modo ela pode auxiliar o nosso trabalho, prossigamos com a breve exposição das teorias de outros estudiosos da comicidade e, concomitantemente, deter-nos-emos um pouco mais demoradamente nas idéias que podem ser interessantes a nossa pesquisa.

De autoria do filósofo Henri Bergson, a obra O Riso foi publicada em 1900. Ela apresenta a célebre teoria de que o risível surge da observação da inadaptabilidade de certas pessoas às convenções sociais. Nesse sentido, a rigidez de indivíduos deslocados do ritmo dinâmico da modernidade leva seus espectadores ao riso. E esse riso coletivo, para Bergson, tem uma função social benéfica, pois serve para a correção dos desvios comportamentais e para a elasticidade da sociabilidade $^{125}$.

Ainda que interessante e por vezes esclarecedora, a teoria de Bergson deve ser apreendida com cautela: nela, a "função social” do riso é sugerida como invariável para todas as sociedades. Bergson está voltado para um modelo de sociedade de tradição humanística, e o riso contribuiria para equilibrar essa sociedade. Além do mais, a idéia de correção e adaptabilidade social não nos parece muito compatível com as sátiras políticas e sociais tão marcantes na literatura de Belmonte. Como já vimos, com sua ironia mordaz, o cronista apontava diretamente para o desvendamento da sociedade brasileira, alvejando seus erros, suas mentiras e hipocrisias.

De qualquer modo, Henri Bergson sugeriu, ainda que com brevidade, algumas idéias secundárias que seriam longamente desenvolvidas pelo psicanalista Sigmund Freud em seu magistral trabalho de 1905. O autor de $O$ Riso percebeu primeiramente uma estreita relação entre o cômico e o sonho. Ambos contêm em si o absurdo, que reflete a inversão da lógica, além da condensação, que é um raciocínio resumido, do qual nos são dados apenas o ponto de partida e a conclusão. ${ }^{126}$ Em segundo lugar, o filósofo francês sugeriu que o uso ininterrupto da lógica e do sentido de alerta é profundamente necessário ao ser humano, mas se revela ao mesmo tempo fatigante, e o riso consistiria, portanto, num rápido alívio desses rígidos aspectos comportamentais exigidos pela civilização moderna ${ }^{127}$.

\footnotetext{
${ }^{124}$ Belmonte, op. cit., p. 25.

${ }^{125}$ Henri Bergson. O Riso. São Paulo: Martins Fontes, 2001, p. 146.

${ }^{126}$ Idem, ibidem, p. 140.

${ }^{127}$ Idem, ibidem, p. 145-146.
} 
No ensaio “Os Chistes e sua Relação com o Inconsciente”, Sigmund Freud estabeleceu relações entre os sonhos e os chistes, e sublinhou semelhanças marcantes entre os dois processos mentais. Ele fez mais: alargando e prolongando a trilha teórica esboçada por Henri Bergson, Freud estudou o prazer suscitado pelo cômico e ligou-o à economia da despesa psíquica. Dito de outra forma, o psicanalista sugeriu que, quando percebemos uma piada apenas como uma piada, abandonamos o sentido de alerta e a relativa rigidez que nos são cobrados como norma de conduta, e relaxamos por um momento: o riso nada mais é que a expressão desse relaxamento, ou do prazer de prescindir, nem que seja por um instante, da energia psíquica exigida. Ou seja, o que era tomado como sério revelou-se uma farsa e justamente por isso nos sentimos aliviados. Logo, o sentido de alerta e a rigidez compõem a despesa psíquica, e a sua economia é prazerosa para a nossa subjetividade.

Outro aspecto a ser destacado no estudo de Freud, de grande importância para a nossa pesquisa, refere-se à ruptura do determinismo no humor. Em geral, os chistes, as piadas e as palavras espirituosas quebram a nossa rigidez comportamental porque contêm uma ruptura de determinismo, de previsibilidade ou de lógica. Tomemos como exemplo a técnica do chiste de condensação, empregada nesse caso como um trocadilho: Freud conta-nos a história de um inglês que chamava os feriados (holidays) de Páscoa de alcoholidays ${ }^{128}$, aludindo à bebedeira dos dias de folga.

Portanto, segundo o psicanalista, a ação dos chistes está ligada a uma súbita mudança efetuada pela ruptura da lógica e pelo predomínio do absurdo (ou do nonsense):

( ...) O adulto torna-se outra vez uma criança, tendo de novo o prazer de dispor de seus pensamentos livremente, sem observar a compulsão da lógica. Espero ter demonstrado que as técnicas do chiste, que utilizam o absurdo, são uma fonte de prazer. Necessito apenas repetir que tal prazer procede de uma economia na despesa ou de um aliviamento da compulsão da crítica. ${ }^{129}$

Georges Minois, em sua excelente obra História do Riso e do Escárnio, considera o nonsense um protesto contra o absurdo da condição humana ${ }^{130}$, aspecto este muito próximo do humor belmontiano. Belmonte fez largo uso do nonsense em muitos dos seus escritos. Peguemos, como

${ }^{128}$ Sigmund Freud, “Os Chistes e sua Relação com o Inconsciente (1905)”, in: Obras psicológicas completas - volume VIII. Rio de Janeiro: Imago, 1977, pp. 34-35.

${ }^{129}$ Idem, ibidem, p. 150.

${ }^{130}$ Cf. Georges Minois. "O riso e os Ídolos no Século XIX”. In: História do Riso e do Escárnio. São Paulo: Editora UNESP, 2003, pp. 497-498. 
exemplo, a crônica Os Hospitaes e a Música, impressa no jornal em setembro de 1933 . Nela, Belmonte versa sobre o péssimo uso do dinheiro público pelas autoridades, além de criticar a penúria material que predominava nos hospitais municipais. O desfecho dessa crônica, contada por meio de um diálogo, é absolutamente inesperado e absurdo:

- E para que cargas d’água essas prefeituras precisam de dinheiro?

- Quem o pode saber? Houve um município, porém, que, interrogado sobre a applicação que dava aos dinheiros públicos, alinhou também aquella série de 'nadas' quando se referiu á instrucção, á hygiene e á assistência hospitalar, mas confessou, no fim, que a única verba que despendia era a de 100 mil réis mensaes para a banda de musica.

- É um prefeito intelligente.

- Eu também acho. Esse, se não dá hospitaes ao povo, se não cuida da hygiene, se não trata da assistência infantil, se finalmente, não garante a vida dos enfermos, ao menos está habilitado a fornecer música para o enterro.

- Já é uma vantagem...” 131

A lógica e o bom-senso são completamente invertidos nessa crônica. Quem concordaria com o abandono das pessoas à sua própria sorte, contando elas com alguma consideração ou lembrança apenas depois de mortas?

Assistimos, assim, a uma total inversão daquilo que seria a atribuição dos gestores municipais. Na escrita de Belmonte, eles estão absolutamente alheios e indiferentes a uma administração pública coerente e racional, direcionada ao bem-estar dos munícipes. Portanto, a atitude das prefeituras em questão só pode ter algum sentido se cruzarmos as fronteiras do absurdo, onde nossas idéias se assemelham àquelas predominantes no estado onírico, aspecto sublinhado por Sigmund Freud e, antes dele, Henri Bergson.

${ }^{131}$ Belmonte, op. cit., p. 146. 


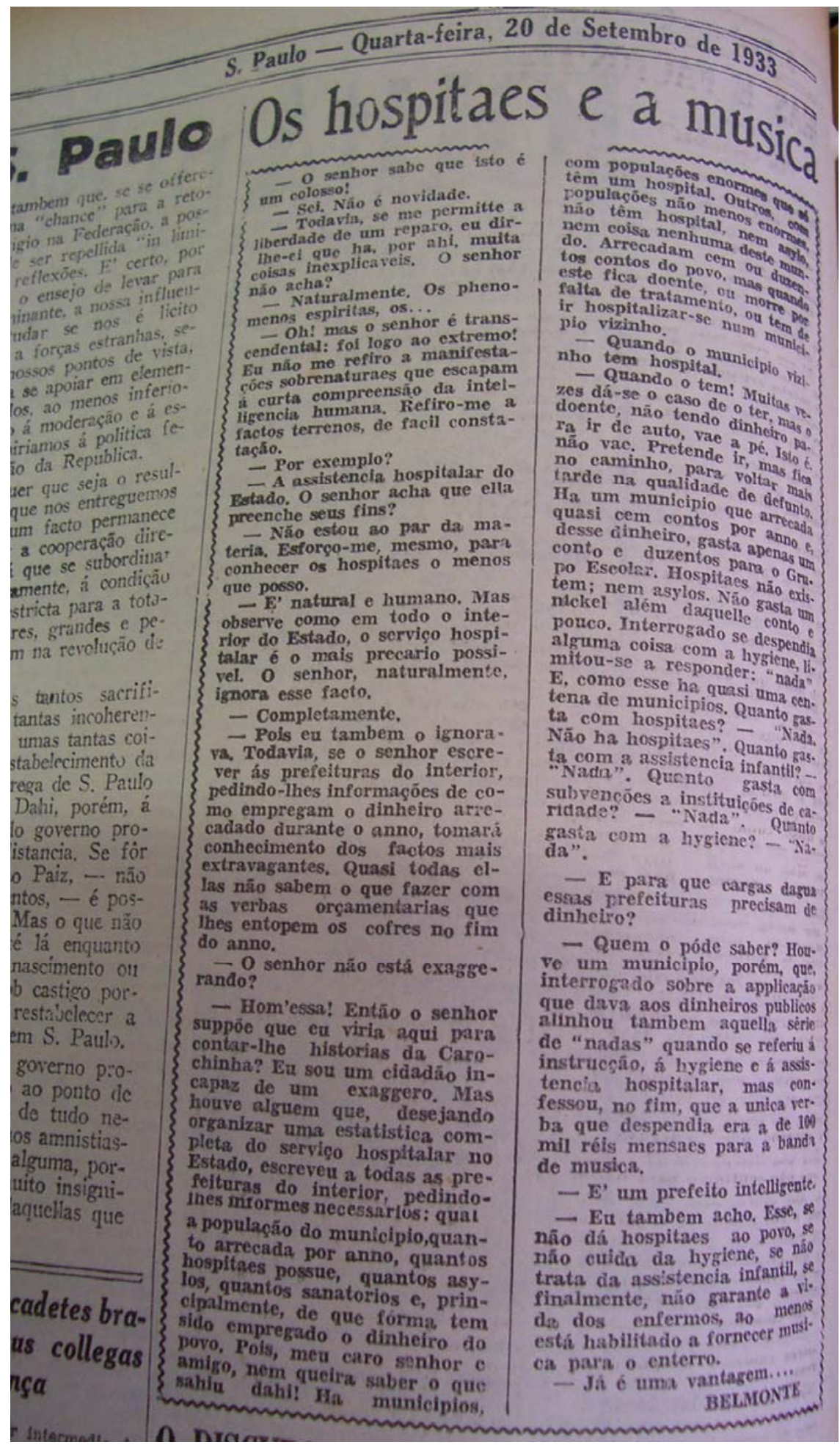

Fig. 8. Os Hospitais e a Música. BELMONTE.

Folha da Noite (São Paulo), 20/09/1933, p. 2.

Hemeroteca do Arquivo do Estado de São Paulo - AE/SP. 
Outro grande nome que figura entre os estudiosos da comicidade é o do russo Mikhail Bakhtin (1895-1975), autor de A Cultura Popular na Idade Média e no Renascimento. O Contexto de François Rabelais. Nesta obra, encontramos um estudo sobre a alegria e o riso medieval e popular. M. Bakhtin apresenta elementos culturais que foram sufocados durante séculos pela repressão de fundamento cristão, revelando-nos um riso marcado pela ambivalência e multiplicidade de significados ${ }^{132}$.

O russo sublinhou a ambivalência do riso, discussão central da obra, e destacou a sua importância para a comunicação humana. Segundo Bakhtin, o cômico costuma suscitar o diálogo, indo, assim, na contracorrente dos discursos antidemocráticos; afinal, a dialogia permite mais de uma interpretação e construção de sentido. Para Bakhtin, o discurso oficial, muitas vezes oriundo de um regime político autoritário, tende a impor uma verdade pré-fabricada e imutável, que não é compatível com discordâncias ou questionamentos. ${ }^{133}$ Georges Minois, historiador do riso, partilha do ponto de vista de Bakhtin ao afirmar que a democracia:

necessita do escárnio, uma vez que o debate livre não pode prescindir da ironia. Riso e democracia são indissociáveis, apesar de os regimes autoritários, que se baseiam num pensamento único, não conseguirem tolerar esse distanciamento criado pelo riso. ${ }^{134}$

No seu estudo sobre o riso, Mikhail Bakhtin assinalou também a presença do nonsense, da quebra da lógica e da previsibilidade em algumas formas do cômico de outrora que sobreviveram até o século XX, como no caso dos disparates, denominados nos séculos XV e XVI coq-à-l'âne $e^{135}$. Ademais, esse autor sistematizou e explicou inúmeros exemplos de paródias ${ }^{136}$, associações ${ }^{137}$ e de ironia.

Mikhail Bakhtin se tornou mais uma das vítimas da política autoritária da URSS, e foi perseguido pelo stalinismo por causa dos estudos que realizava acerca da linguagem, em especial sobre o escritor Dostoiévski, visto com desconfiança por esse regime. Em 1929 ele publicou na União Soviética Problemas das Obras Criativas de Dostoiévski ${ }^{138}$, em que salientou o dialogismo na

\footnotetext{
${ }^{132}$ Ver Mikhail Bakhtin, op. cit., p. 18-25 e p. 356 a 372 passim.

${ }^{133}$ Idem, ibidem, pp. 08-10.

${ }^{134}$ Cf. Georges Minois, op. Cit., pp. 461-462.

${ }^{135}$ Mikhail Bakhtin, 1996, pp. 371-372.

${ }^{136}$ Idem, ibidem, p. 67.

${ }^{137}$ Idem, ibidem, pp. 165-167.

${ }^{138}$ Uma segunda edição seria publicada apenas em 1963. Ela foi submetida a diversas modificações (feitas por Bakhtin) e recebeu o título de Problemas da Poética de Dostoiévski.
} 
escrita desse literato russo ${ }^{139}$. Segundo Bakhtin, Dostoiévski foi um dos grandes nomes da escrita polifônica ou dialógica ${ }^{140}$, pois empregou procedimentos formais que lhe permitiram levar cada uma de suas personagens a falar em voz própria e com um mínimo de interferência do escritor, oferecendo, assim, variados pontos de vista ao leitor.

Com seu estudo sobre Dostoiévski, Bakhtin procurou alertar para a estreiteza da fala monológica, inimiga das diferenças e fortemente predisposta ao autoritarismo:

\begin{abstract}
Bakhtin pleiteia a superioridade de uma abordagem dialógica da literatura e da vida em relação a uma abordagem monológica, mas ele o faz em diferentes vozes e por diferentes argumentos. Quando encerra o estudo sobre Dostoievski exortando seus leitores a renunciar a seus velhos hábitos monológicos, seu gesto constitui um comentário a uma situação política que só permitia crescentemente a audição de uma única voz autorizada e que enviava ao exílio aqueles que, como o próprio Bakhtin, não podiam ser monologizados. ${ }^{141}$
\end{abstract}

O teórico que criticou o discurso único e autoritário sofreu com a sua ousadia. Os burocratas da educação, partidários do stalinismo, não lhe permitiram a integração nos centros intelectuais russos, empurrando-o para a obscuridade acadêmica. Voltando do exílio, em 1936, Bakhtin ocupou um cargo docente numa faculdade para a formação de professores na Mordóvia. Em seguida, retirouse para uma pequena cidade próxima a Moscou, e por lá permaneceu durante toda a Segunda Guerra Mundial. Após o fim do conflito ele voltou para seu posto na faculdade da Mordóvia, e nele se aposentou, em 1961, não conseguindo ocupar um cargo de docente em faculdades mais centrais e prestigiadas $^{142}$. O trabalho teórico de Bakhtin só foi “descoberto” no Ocidente e na União Soviética em 1963, quando houve a publicação da segunda edição de seu livro sobre Dostoiévski ${ }^{143}$.

Sigmund Freud, Mikhail Bakhtin e Vladimir Propp deram grande destaque à ironia, um dos recursos da comicidade mais empregados pelo humor. Esses teóricos do riso salientaram que a ironia almeja o significado oposto do que é colocado ${ }^{144}$. Vladimir Propp e Mikhail Bakhtin acrescentaram ainda que a ironia consiste no seguinte: em palavras, coloca-se algo positivo sobre algo ou alguém,

\footnotetext{
${ }^{139}$ Katerina Klark e Michael Holquist. Mikhail Bakhtin. São Paulo: Perspectiva, 2004, p. 258-259.

140 “O que Bakhtin chama de polifonia é simplesmente aquele fenômeno cujo outro nome vem a ser dialogismo”. Ver Katerina Klark e Michael Holquist, op. cit, p. 261.

${ }^{141}$ Idem, ibidem, p. 269.

${ }^{142}$ Idem, ibidem, pp. 21-22.

${ }^{143}$ Beth Brait (org.). Bakhtin: dialogismo e construção do sentido. Campinas, SP: Editora Unicamp, 2006, p. 14.

${ }^{144}$ Ver Vladimir Propp, op. cit., p. 125, Sigmund Freud, op. cit., pp. 198-199, e Mikhail Bakhtin, 1996, pp. $138-139$.
} 
pretendendo, ao contrário, expressar algo negativo, o avesso do que foi dito. ${ }^{145} \mathrm{Com}$ a ironia, temos, portanto, um recurso cômico que já nos parece bastante familiar: a busca pelo oposto, que conduz a compreensão do leitor ao desmascaramento de defeitos ou vícios. Entretanto, o sucesso do emprego da ironia depende, em larga medida, não apenas daquele que a elabora, mas também do preparo do leitor para identificá-la e “decifrá-la”.

Ainda que Belmonte fosse um humorista do lápis, sua personalidade era acabrunhada e tristonha. Doentiamente tímido, falava pouco ${ }^{146}$, provavelmente uma característica natural da sua personalidade. Podemos supor, porém, que a alma de Belmonte fora capturada por uma angústia muito própria à profissão de humorista: “...quando um escritor em plena força de suas qualidades e genialidade é condenado a representar durante toda a sua vida o avesso da vida e, com isso, provocar o riso, sua genialidade se transforma num destino trágico" ${ }^{147}$. Talvez Belmonte tenha sofrido do mesmo sentimento trágico que acometeu Gogol e, não obstante, em lugar de enxergar a humanidade com um juízo de valor menos crítico, passou a ver apenas enganadores, aproveitadores, falsários e homicidas. Ou, como diria Gogol, “...eu não vejo nada. Vejo apenas focinhos de porco em lugar de rostos e nada mais.” 148

Para o artista, portanto, o Governo Provisório brasileiro realizava o avesso de tudo aquilo que ele havia se proposto a fazer. Em lugar de fortalecer a democracia, planejava a ditadura e cortejava o autoritarismo; em vez do Federalismo, estruturava o intervencionismo e a centralização. Nesse sentido, a vingança de Belmonte voltava-se para rir do governo “revolucionário”, desmascarando o quão ele carregava de conservação, de "velho", e sublinhando suas tendências de retrocesso. Os progressos econômicos e sociais, incansavelmente propalados pelo Varguismo como seus feitos ${ }^{149}$, configuram-se, nas crônicas, em seu exato oposto: na inoperância e na ineficiência.

Se na Primeira República o governo era acusado por seus inimigos de servir apenas aos interesses econômicos e políticos de um pequeno grupo de pessoas, chamado de Oligarquia, sob o lápis do humorista, a história parecia se repetir na República Nova, ainda que os atores envolvidos nas negociações políticas e falcatruas financeiras fossem outros - homens públicos relativamente jovens em suas carreiras, que ascenderam a seus cargos com a derrocada do governo Washington Luís.

\footnotetext{
${ }^{145}$ Ver Vladimir Propp, op. cit., p. 125; Mikhail Bakhtin, 1996, p. 139.

${ }^{146}$ Ver prefácio escrito por Paulo Duarte, op. cit., p. 01. Ver também Andréa de Araújo Nogueira, op. cit., p. 69.

${ }^{147}$ Ver Vladimir Propp, op. cit., p. 183.

${ }^{148}$ Ibidem.

${ }^{149}$ Cf. Getúlio Vargas. A Nova Política do Brasil - II - O ano de 1932. A Revolução e o Norte / 1933. Rio de Janeiro: José Olympio, 1938. Ver o manifesto à Nação lido no edifício da Câmara dos Deputados, a 14 de maio de 1932: "A Revolução e o regime legal”, especialmente as páginas 37-43.
} 
É facilmente compreensível que no discurso dos líderes revolucionários, o governo pós-1930 surja como o "reconstrutor moral e material da Pátria”, “saneador dos costumes políticos”150, “apressador do progresso do país” ${ }^{151}$, “regenerador” e como o "salvador” da Nação ${ }^{152}$. E ao se posicionar no pólo oposto da república de antanho, que se destinava para muito poucos, a república de então frisava a sua total concordância com as “aspirações nacionais”, termo este um tanto abstrato, ainda que, à época, bastante atraente ${ }^{153}$ :

Acresce, além disso, não ser objetivo da Revolução triunfante a mudança de homens, e, sim, a substituição orgânica e profunda de métodos, de processos e normas de vida pública. Sabe também o Govêrno que interpreta, exprime e defende os superiores interêsses nacionais, em íntima e perfeita correspondência com as necessidades, os sentimentos e as aspirações do país. ${ }^{154}$

Em grande parte de suas crônicas, Belmonte emprega exatamente as mesmas palavras de valorização das ações do Governo Provisório (1933) e da República Nova (1934), usadas exaustivamente pelos seus chefes, dentre os quais Getúlio Vargas. No entanto, nas linhas do humorista, elas ganham um sentido irônico avesso ao significado grave e respeitoso imposto a elas pelos homens do governo. Nesse aspecto, os leitores que tivessem algum conhecimento em política prontamente relacionariam essas palavras com o discurso dos revolucionários, e perceberiam a “traquinagem” literária do artista - inverter ou modificar o sentido delas com o objetivo de melhor rir do poder:

\begin{abstract}
Ainda ante-hontem, o honrado senhor José Américo teve a gentileza de conversar com um jornalista, dizendo cousas de alta e profunda sabedoria, graças ás quaes fiquei sabendo que eu tinha varias toneladas de razão quando, há mais de três annos, escrevinhei aqui umas graves considerações a sobre a inefficiencia da gente nova nos serviços públicos (...). o honrado senhor José Américo, um dos poucos estadistas indígenas que têm sinceridade bastante para dizer o que pensam, disse a um repórter as seguintes palavras:
\end{abstract}

- Se nada fiz como ministro, muito aprendi em tal posto.

\footnotetext{
${ }^{150}$ Cf. Getúlio Vargas, op. Cit., p. 18.

${ }^{151}$ Idem, p. 46.

${ }^{152}$ Idem, pp. 56-57.

153 Praticamente todos os grupos políticos procuravam falar em nome da nação e frisavam que defendiam legitimamente os interesses dela: os liberais, os comunistas stalinistas e os fascistas, além do próprio governo.

${ }^{154}$ Cf. Getúlio Vargas, op. Cit., pp. 56-57.
} 
Essas palavras, traduzidas em vulgacho, querem dizer exactamente aquillo que eu dizia há três annos atrás, isto é, que gente nova em republica velha, acaba sempre nisso que ahi está. É verdade que, para não dar muito na vista, os regeneradores resolveram pregar nas costas do regime uma vasta taboleta com estes dizeres: 'República Nova'.

Isso, todavia, em nada alterou a situação porque não houve Voronoff de espírito revolucionário que conseguisse remoçar a madama. Póde dizer-se, mesmo, que em quatro annos de experiências, a Republica envelheceu mais do que nos quarenta anteriores. E envelheceu, justamente, de tanto ensinar a brava rapaziada que surgira, de repente, não se sabe de onde, mas que estava disposta a 'ir ate o fim', custasse o que custasse.” $^{155}$ [grifos nossos]

Sob a pena do escritor, os novos políticos não portavam a inovação e a modificação, mas sim a inexperiência e a incompetência. Seu governo desordenado e confuso não trouxe as mudanças prometidas à época da Aliança Liberal e a única (e forçada) opção que restou aos “regeneradores” para tentar despistar o povo enganado foi pregar nas costas do regime uma enorme placa com os dizeres “República Nova”. Para Belmonte, os governantes pós-1930 continham não apenas uma imensa possibilidade de conservação, mas mesmo de retrocesso, uma vez que nos últimos quatro anos, por causa das inaptidões da "brava rapaziada”, a república envelhecera mais do que nos quarenta anos anteriores.

O novo governo, portanto, não trouxera modificações benéficas ou significativas ao país. Ainda que as repartições e cargos públicos mudassem de endereço ou nome, a estrutura de funcionamento prosseguia a mesma. Na crônica Não me troque o nome!, de 11/08/1933, são salientadas as constantes mudanças de nome do Departamento de Educação. Após 1930, ele recebeu algumas alcunhas dos interventores federais em São Paulo; primeiramente, a então "Inspectoria Geral de Ensino” tornou-se "Directoria Geral de Ensino”, pois, como lhe foi nomeado um diretor, ela não mais poderia se chamar inspetoria. Em 1932, quando houve mudança de interventor, a ex-diretoria foi nomeada "Departamento de Educação”. Agora, nos idos de agosto de 1933, o interventor de São Paulo mostra-se desejoso em restabelecer o nome "Directoria Geral de Ensino", sem motivo ou necessidade que justifique a nova mudança. Apesar dos nomes diversificados, o artista assegura que

\footnotetext{
155 Belmonte. Os Máus Alumnos. Crônica publicada na Folha da Noite (São Paulo) em 30/07/1934, p. 2. Livro Idéas de João Ninguém, na p. 176.
} 
“No fundo, tudo isso é a mesma cousa.”" ${ }^{256}$. Crítico da inexistência de um bom ensino público, universal e obrigatório, ele salienta em algumas crônicas que o ensinamento continuava ruim, e que a insuficiência de escolas e de professores era evidente. Ademais, estes eram muito mal remunerados, o que revoltava o artista.

Belmonte procura mostrar ao seu leitor que não houvera mudanças para melhor no Governo Provisório, que tudo não passara de palavreado vazio. O final da crônica é hilário, pois o artista relaciona a ausência de efetiva transformação, oculta por trás das incessantes mudanças de nome, com a previsibilidade metódica do trabalho intestinal, ou seja, a mesmice com a mesmice:

Imaginem os apuros de um pobre diabo que sae a procura de uma repartição qualquer: “Directoria Geral da Alimentação Pública” por exemplo. Elle pergunta onde fica isso. Respondem-lhe que é em tal rua. Vae até lá.

Mas, no local indicado, há uma grande placa: 'Departamento Districtal das Comedorias'.

- Ué. Disseram-me que era aqui a 'Directoria Geral da Alimentação Pública’ e vejo que me enganei porque aquella placa me affirma que aqui é o 'Departamento Districtal das Comedorias'.

- É não! Foi! Hoje, isto aqui é a 'Inspectoria Seccional do Estomago Público’. Mas da semana que vem em deante isto vae ser a 'Secretaria Interurbana do Intestino Popular'.

- Mas ahí por dentro não é a mesma coisa?”157 [grifos nossos]

Esta última linha suscita duas interpretações que se completam: a primeira, de que são muitos os nomes empregados para uma mesma e única atividade; e a segunda, de que os processos de ingestão, digestão e evacuação configuram-se sempre em um repetitivo e previsível trabalho corporal. De qualquer forma, tanto de um lado como do outro, não há nada de novo.

As crônicas de Belmonte sublinham com freqüência as mentiras propaladas pelos governantes revolucionários. Ainda que estes afirmassem pública e categoricamente que se situavam no pólo oposto da política oligárquica de outrora, e que governavam para todo o povo brasileiro - e não mais apenas para um grupo, como fizera a Primeira República -, o artista frisa que, depois de empossados nos cargos políticos, eles se empenharam em conquistar apenas seus interesses pessoais: poder, enriquecimento financeiro e conforto.

\footnotetext{
${ }^{156}$ Belmonte. Não me troque o nome!. Crônica publicada na Folha da Noite (São Paulo) em 11/08/1933, p. 2.

${ }^{157}$ Idem, ibidem.
} 
Percebe-se que, se os governantes pós-1930 acusavam os homens da República Velha de serem oligarcas e de terem governado voltados apenas para os interesses da Oligarquia, o cronista das Folhas, por sua vez, apontava que somente a "facção" dos revolucionários alcançara vantagens com o advento do novo governo. Em 1930, portanto, o poder fora arrebatado das mãos de um grupo para prontamente tornar a cair nas mãos de outro grupo restrito, de modo que a maioria dos cidadãos brasileiros continuava apartada da política.

A fala seguinte de Getúlio Vargas (1932) que relembra o favoritismo oligárquico da Primeira República é bastante elucidativa, pois mostra como os vitoriosos revolucionários apreenderam e desmoralizaram seus antecessores:

Os vinte estados em que se subdividiram o mapa do Brasil, anulado o poder de representação, válvula de segurança do regime, com raras exceções, debatiam-se presas de governos oligárquicos, que exploravam, em benefício próprio, as posições e os proventos materiais.

Os Governadores, em concílio, elegiam o Presidente da República, que, por sua vez, determinava sobre a substituição dos governos locais. Os deputados eram simples mandatários da vontade arbitrária dos régulos estaduais (...). Terminado o mandato, os Governadores aposentavam-se no Senado, ocupando o lugar dos que iam substituí-los nos Estados, em um revesamento atentatório da moral política. A velha e respeitável instituição transformara-se em remanso de repouso farto, pitorescamente caracterizada por um parlamentar ilustre da época como uma "maternidade para a desova das oligarquias". ${ }^{158}$ [grifos nossos]

O então Presidente do Brasil construiu seu discurso de modo que a política da Primeira República surgia como um velho e conhecido negócio em família, onde não ocorriam discordâncias ou conflitos intensos. Afinal, todos eram oligarcas. Logo, tinham interesses próximos.

Entretanto, para Belmonte, o novo governo não trouxera mudanças benéficas ao país. A forma de se fazer política prosseguia num negócio de “compadres”, tendo sido trocados apenas os atores principais:

E, em verdade, vos digo, leitores amigos, que quando o senhor general [Góes Monteiro] affirma que na República Nova não há incidentes, nem crises, mas apenas equívocos, é porque o senhor general sabe muito bem que lobo não come lobo e que

${ }^{158}$ Cf. Getúlio Vargas, op. Cit., pp. 27-28. 
sururus em família não se chamam conflictos, mas apenas desavenças domésticas que terminam quando chegam as visitas. ${ }^{159}$ [grifos nossos]

Dentre as muitas críticas direcionadas aos políticos da República Velha (chamados de carcomidos) pelos getulistas, no início da década de trinta, figurava aquela que os acusavam de má gerência do dinheiro público. Concomitantemente, eles também eram tomados por desonestos.

Ao versar em seus discursos sobre o funcionamento da corrupta máquina administrativa de seus antecessores, disse Getúlio Vargas:

Nessa atmosfera de convenções e de artifícios, a advocacia administrativa, instituída como profissão paralela aos mandatos políticos, delapidava o Tesouro e corrompia a vida pública do país, oscilando entre o congresso e as repartições. A justiça, principalmente a dos estados, falhava na sua alta magistratura. Selecionada pelo favoritismo dos poderosos, mal remunerada e sem garantias indispensáveis, carecia da necessária independência de julgamento.”160 [grifos nossos]

Segundo ele, a irresponsabilidade financeira grassava na malograda república de outrora, ao contrário daquela presidida por ele ${ }^{161}$ :

Financeiramente, o esbanjamento sem medida, o favoritismo, as obras suntuárias, acarretavam formidáveis déficits, cobertos, de modo nefasto e permanente, por empréstimos do capitalismo estrangeiro, de ano para ano, os onerosos encargos da dívida pública.

Eis o regime abatido pela Revolução de $1930{ }^{162}$ [grifos nossos]

Ignorando por completo a brusca delimitação entre a República Nova e a República Velha, forçosamente estabelecida pelos políticos revolucionários, Belmonte sugere que a corrupção ganhou um novo fôlego no governo dos “regeneradores” e "saneadores” da Pátria. Na crônica Os Equívocos,

\footnotetext{
${ }^{159}$ Belmonte. Os Equívocos. Crônica publicada na Folha da Noite (São Paulo) em 19/05/1934, p. 2. Livro Idéas de João Ninguém, na p. 173.

${ }^{160}$ Cf. Getúlio Vargas, op. Cit., p. 28.

${ }^{161}$ No discurso de Vargas, ainda nos dois primeiros anos do governo provisório, a moralização dos gastos públicos e um maior equilíbrio dos mesmos já era uma realidade: "A reação que se observa na vida econômica do país já apresenta caráter de segura solidez. O saneamento financeiro emprestou o almejado equilíbrio aos orçamentos da União e dos estados. Por outro lado, a severa aplicação de normas administrativas moralizadoras imprime seu cunho regenerador na gestão dos negócios públicos.” Idem, p. 54.

${ }^{162}$ Idem, p. 29.
} 
de 19/05/1934, o escritor cita vários casos de apropriação indevida do dinheiro público por alguns dos líderes do novo governo:

Mas, como com muita finura observou o general P. Góes, não foram esses os únicos equívocos da revolução. E não foram mesmo. O caso do cambio negro, a 'alta operação financeira' da banha, a camaradagem revolucionaria da Caixa Econômica, o arranha-céo da secca do Ceará e outros almoços semelhantes, tudo isso são equívocos. ${ }^{163}$ [grifos nossos]

Belmonte referia-se aos acontecimentos que tiveram repercussão nas folhas do jornal no qual ele trabalhava. O Ministério de José Américo, por exemplo, recebera do governo federal uma quantia em dinheiro para aliviar os impactos da seca no Nordeste, em especial no estado do Ceará. Entretanto, o ministro deu a grande parte do capital uma destinação diversa e esta, por sua vez, pouco tinha que ver com medidas de combate à seca (conforme a expressão “arranha-céu da seca”). Ademais, parte da fortuna da Caixa Econômica do Estado de São Paulo também fora indevidamente apropriada por homens públicos ou, pelo menos, isso era especulado pela imprensa, especialmente pelas Folhas, periódicos opositores ao governo.

Logo após elencar as corrupções supostamente efetuadas por personalidades da República Nova, o artista desdobra uma sucessão de ironias ferinas, tão cínicas quanto procurar desculpar os roubos do erário públicos com as palavras “equívocos” ou “enganos”:

Os bravos cidadãos que se mettem nessas empreitadas cívicas, não o fazem por mal isto é, não agem com intuitos menos confessáveis. Vão sempre com a melhor das intenções. Mas enganam-se! E ahi é que é o diabo! ${ }^{164}$ [grifos nossos]

O epílogo do que parecia ter se tornado uma era de corrupção desenfreada, mais grave ainda do que aquela que grassava na Primeira República, só podia ser a falência completa do país. Munido de sua incansável verve irônica, arremata o artista:

Ainda há pouco, o sr. Juarez Távora declarou que todo o dinheiro do Brasil fora gasto. Não havia um nickel sequer, nem para comprar uma empadinha de segunda mão. Mas, como frizou, esse dinheiro fôra gasto na 'defesa do patrimônio nacional'. Como

\footnotetext{
${ }^{163}$ Belmonte. Os Equívocos. Crônica publicada na Folha da Noite (São Paulo) em 19/05/1934, p. 2. Livro Idéas de João Ninguém, na p. 174.

${ }^{164}$ Idem, pp. 174-175.
} 
se vê, gastaram-no com a melhor das intenções. Mas, como o patrimônio nacional, apesar disso, continuou sem defesa, constatou-se logo que houvera outro equívoco. Que culpa têm elles? Nenhuma." 165 [grifos nossos]

Além da ironia presente nas últimas três linhas, temos o emprego de um exagero retórico que também é cômico: o Brasil estava tão empobrecido que faltavam-lhe fundos até para comprar uma empadinha de má qualidade. A causa principal da penúria material do país, segundo a crônica, estava no uso desonesto e displicente do dinheiro público.

Na crônica A Capital Federal (06/03/1934), ainda que a temática principal não seja a corrupção, vemos políticos revolucionários preocupados apenas com o seu bem-estar, em lugar de se ocuparem do governo do país. A questão girava em torno do local em que deveria ser instalada a Capital Federal. A proposta original de construí-la em Goiás, com o intuito de habitar o vasto e ermo interior brasileiro, logo foi rechaçada pelos revolucionários, pois, ao conversarem com um político que conhecia aquela região, o Sr. Pedro Ludovico, descobriram que ela tinha aspectos um tanto desagradáveis e desistiram da idéia inicial de serem os primeiros a povoarem-na. Não obstante, começaram a procurar na geografia do país um local adequado (leia-se: agradável e prazeroso) para a instalação da Capital Federal:

Ficaram sabendo, então, que o lugar famoso onde se pretendia installar a capital da República estava muito longe de qualquer coisa parecida com Cariry ou com Sant’Anna do Livramento, pois não havia por lá outra coisa, até esse momento dramático, senão mattaria, cobras e carrapatos. E, além disso, havia calor.

Houve, como é de se prever, uma terrível desillusão - Como? Então nós, ministros e interventores, vamos deixar a nossa vidinha flauteada da Avenida, para nos mettermos no matto?!

E os próceres, recolhidos aos seus gabinetes austeros, debruçados sobre mappas immensos, soltaram a imaginação á procura de uma solução feliz para tão acabrunhante problema. ${ }^{166}$ [grifos nossos]

Os políticos da República Nova não se dispuseram, de forma alguma, a abandonar a sua vida “na flauta” (ou seja, tranqüilamente), da cidade do Rio de Janeiro para irem “desbravar” uma região inóspita, cheia de bichos peçonhentos e exageradamente quente. Seria necessário muito patriotismo para tanto, característica da qual, segundo assegura-nos o desenrolar da crônica, eles evidentemente

\footnotetext{
${ }^{165}$ Idem, p. 175.

${ }^{166}$ Belmonte. A Capital Federal. Crônica publicada na Folha da Noite (São Paulo) em 06/03/1934, p. 2.
} 
carecem. Além do mais, no sentido em que foram empregados, os adjetivos "austeros” e “acabrunhante” não dizem respeito às atribuições do governo, ou seja, ao destino da grande maioria dos quase quarenta milhões de brasileiros, mas sim à grave ameaça ao conforto dos políticos getulistas, assunto este primordial para eles.

O fato é que, durante algum tempo, se pensou sobre qual local ou cidade poderia ser erigida a nova capital federal. "O problema, pois, continuava terrivelmente, desesperadoramente insolúvel, quando, hontem, um gênio descobriu a pólvora, isto é, solucionou o caso acabrunhante»167. O esperto indivíduo em questão, de nome Solano da Cunha, propôs a cidade serrana de Petrópolis como sede administrativa do país. Anteriormente, o prosseguimento da Capital Federal na cidade do Rio de Janeiro fora sugerida por outro político, pois ela contava com a “...praia gostosa de Copacabana”168 . Entretanto, como foi bem lembrado, o calor que fazia na cidade era profundamente desagradável:

- Oh! Não! O Rio é uma delícia, mas o diabo é este calor! Isso asphyxia, não nos deixa trabalhar!

- É verdade. Este calor é um buraco! ${ }^{169}$

Mas a partir de então, com a perspicaz proposta de Cunha, acabaram-se os problemas dos políticos. Durante os meses de calor excessivo eles poderiam permanecer no clima ameno de Petrópolis, estando, ao mesmo tempo, relativamente próximos das praias do Rio. As últimas linhas dão o fecho com uma excelente zombaria voltada aos revolucionários:

Agora, porém, Suas Excellências ficarão entre as hortencias petropolitanas, respirando aquelle optimo ar serrano e, quando o calor amainar um pouco, poderão dar um pulo até a Avenida ou até Copacabana para, entre as lindas morenas cariocas, salvarem a Pátria.

E digam depois que a revolução não tem feito nada que preste... ${ }^{170}$ [grifos nossos]

Nesta hilária crônica criada por Belmonte, percebe-se que a história não progride, não prossegue em linha reta, mas sim em círculo, pois, desde o Reinado de Pedro II que os governantes partiam para Petrópolis durante os meses mais quentes do ano, fugindo do calor e de doenças epidêmicas. No início do século XX, a cidade figurava como lugar de veraneio para os

\footnotetext{
${ }^{167}$ Idem, ibidem.

${ }^{168}$ Idem, ibidem.

169 Idem, ibidem.

${ }^{170}$ Idem, ibidem.
} 
endinheirados, em nítido contraste com a miséria e o desconforto de Zé Povo ${ }^{171}$. Naqueles idos de 1934, porém, as moléstias tropicais já não se configuravam no motivo da mudança dos políticos. O conforto e o prazer dominavam-nos em absoluto.

Percebe-se também uma indistinção por parte dos “representantes do povo” das atividades públicas e privadas. As entrelinhas dão a entender que, no litoral, os distintos senhores "salvariam a Pátria” nos braços de belas morenas, e a Revolução de 1930, promessa frustrada para o homem comum, serviu apenas ao gozo e aos interesses estritamente pessoais dos homens que ascenderam ao poder com a derrocada da Primeira República.

O potencial de retrocesso do governo brasileiro é apontado e criticado pelo artista em alguns de seus escritos. Ora a República Nova é a continuação do “velho” ora é a regressão, e este último é o caso da crônica Carta aberta ao Prof. Desiderius Paap.

A história se inicia com Belmonte entretido na redação de uma carta para um cientista alemão que, segundo suas pesquisas, afirmara em seu livro que dentro de 500 milhões de anos o homem estaria completamente diferente, e fisicamente muito mais "avançado": ele ostentaria três metros de altura, teria perdido os pelos e dentes por falta de uso, a cabeça seria imensa e o cérebro, muito desenvolvido, receberia e transmitiria ondas eletromagnéticas. Os olhos, além da visão, teriam a mesma função do raio-X.

Nas linhas de sua correspondência, o artista se apresenta ao cientista e pede licença para discordar dele. Segundo Belmonte, o homem não avançará nem na organização de seus governos e nem fisicamente, pois a evolução - a história - dava mostras de ser cíclica, por causa das guerras e crises sociais, políticas e econômicas que vinham ocorrendo nas últimas duas décadas; elas surgiam ao escritor como um indubitável retrocesso.

Por meio da expressão “governos fortes” ele zomba indiretamente do governo autoritário, mais militarizado e centralizado de Getúlio Vargas, como também de outros tantos com essas semelhanças:

E, com effeito, ao cabo de trinta e seis horas de estudos, pesquisas, analyses, confrontos e deducções, conclui que a teoria lamarckiana é ainda das mais acceitáveis, mas que a evolução cyclica não é uma fantasia. Se, no terreno sociológico, nós vamos regredindo, realizando uma espécie de cyclo histórico que nos está levando de novo para os 'governos fortes' e para a aristocracia medieval, no terreno biológico cahiremos no mesmo rythmo, tendem para um recuo primitivista. A eletricidade não

${ }^{171}$ Marcos A. da Silva. Caricata República. Zé Povo e o Brasil. São Paulo: Marco Zero/CNPq, 1990, pp. 23-24. 
tem importância. O importante é que todo o mundo prega a necessidade da força physica, toda a gente faz esportes, doutrina-se sobre as excellencias da vida primitivista, e pratica-se o nudismo. É o ambiente bárbaro que está se formando. E o 'meio' em que vae actuar o homem do futuro, o 'meio' troglodyta (...).

É a 'evolução cyclica'. Nós viemos até aqui, até este cume majestoso da Civilização e agora vamos descer a encosta, para voltar ao passado, ao medievalismo, ao primitivismo, ao Paraíso perdido. Essa história de ' homens electro-magnético’ do meu venerado collega é uma fantasia de sábio allemão. Nós (não daqui a 500 milhões de annos) mas muito antes, vamos acabar como os homens da caverna, barbudos, peludos, cabelludos, nús como a Verdade, caçando onças no Jabaquara. ${ }^{172}$ [grifos nossos]

Os “governos fortes”, portanto, fazem parte de um processo histórico que culminará em um retrocesso absoluto. Ele desembocará de volta à pré-história e à barbárie. É interessante quando o artista coloca que no "terreno biológico”, um dos aspectos da regressão humana seria “...que todo o mundo prega a necessidade da força physica”. Naquele período, com a exaltação do nacionalismo e a ascensão de regimes políticos de extrema-direita, a força física e a inclemência de homens e meninos eram intensamente estimuladas, principalmente pelos fascismos italiano e alemão, na formação de seus exércitos expansionistas.

No último parágrafo transcrito, o artista apresenta propositalmente uma visão do percurso da história humana oposta àquela do progresso: “É a 'evolução cyclica’. Nós viemos até aqui, até este cume majestoso da Civilização e agora vamos descer a encosta, para voltar ao passado, ao medievalismo, ao primitivismo, ao Paraíso perdido.” ${ }^{173}$

Antes do período do Iluminismo, a concepção dominante de história era a cíclica, para a qual todas as sociedades passavam, indubitavelmente, por fases de progresso, apogeu e decadência. Portanto, segundo Belmonte, o advento dos governos fortes era um indício de que a sociedade ocidental estava no processo de decadência que culminaria na barbárie. Isso não queria dizer que o artista concordava com essa visão da história, mas sim que ele se apropriou dela para sublinhar o retrocesso intrínseco dos governos autoritários, “fortes”. Logo, percebe-se uma erudição considerável por parte de Belmonte.

Montesquieu expressa bem essa visão cíclica da história na compilação de seus pensamentos (1716-1755), publicada em 1917:

\footnotetext{
${ }^{172}$ Belmonte. Carta aberta ao Prof. Desiderius Paap. Crônica publicada na Folha da Noite (São Paulo) em 08/02/1934, p. 2; e no livro Idéas de João Ninguém, pp. 29-31.

${ }^{173}$ Idem, ibidem.
} 
Quase todas as nações do mundo seguem este ciclo: primeiro são bárbaras; conquistam e tornam-se nações civilizadas; essa civilização fá-las maiores e tornam-se nações polidas; a polidez enfraquece-as; são conquistadas e voltam a ser bárbaras. Como provas destas afirmações temos os Gregos e os Romanos. ${ }^{174}$

Após a segunda metade do século XVIII, entretanto, a visão da história como progresso passou a ser mais aceita e disseminada pelos filósofos. Para os Enciclopedistas (1751-1765), a crença no progresso passou a ser a base de sua fé ${ }^{175}$.

Em 1772, o Marquês de Chastellux publicou uma obra intitulada De la felicité publique, onde defendia que em nenhuma época do passado o homem foi mais feliz do que no presente e que o progresso no futuro estaria assegurado, fazendo recuar a guerra e o fanatismo religioso. Já Volney (Les ruines ou méditations sur les révolutions des empires, 1791) acreditava em um processo progressivo que continuaria até que toda a espécie humana formasse uma única e grande sociedade, dirigida pelas mesmas leis, e que gozasse toda a felicidade de que a natureza humana fosse capaz ${ }^{176}$.

Mas o auge desta ideologia do progresso deu-se durante a Revolução Francesa, com o Esquisse dun tableau historique des progrès de l'espirit humain (1793-94), de Condorcet. Ele insistia na importância das ciências e das técnicas, e sustentava a idéia de que o progresso no conhecimento seria a causa do progresso social e geraria liberdade e igualdade ${ }^{177}$.

Quando o escritor se refere ao nudismo, além dele estar sugerindo o retorno cíclico ao "meio bárbaro”, provavelmente está gracejando com os europeus, especialmente com os alemães, que o praticavam. Obviamente, eles faziam parte de grupos seletos. Na Alemanha, ainda na época da República de Weimar,

...os momentos de relaxamento [da juventude] eram proporcionados pelos piqueniques regados a cerveja e pelos esportes, lazeres que passaram a ser organizados pelos nazistas e pelos comunistas como forma de libertação da opressão burguesa. Mas para outros, a libertação estava no nudismo, prática que não era acompanhado de amor livre, limitando-se à ginástica e ao banho. ${ }^{178}$

\footnotetext{
${ }^{174}$ Cf. Jacques Le Goff. “Progresso/Reação”. In: Enciclopédia Einaudi - volume 1 - Memória-História. Porto: Imprensa Nacional/Casa da Moeda, 1984, p. 347.

${ }^{175}$ Cf. Jacques Le Goff, op. Cit., p. 349.

${ }^{176}$ Idem, p. 350.

${ }^{177}$ Idem, ibidem.

178 Cf. Luiz Nazário. “O Expressionismo e seu Contexto. 1. Quadro Histórico”, in: GUINSBURG, J. (org.). O Expressionismo. São Paulo: Perspectiva, 2002, p. 33.
} 
Ademais, nas décadas vinte e trinta, a prática de esportes estava na ordem do dia, tanto na Europa como nas metrópoles brasileiras. Ela se ligava ao cuidado com o corpo e a saúde, como também à competição, onde a rígida disciplina e a resistência física imperavam. Com seu ritmo frenético e competitivo, a prática esportiva mantinha suas semelhanças com a produção industrial capitalista, que vinha se desenvolvendo a todo vapor em São Paulo, especialmente na capital desse estado $^{179}$.

Veremos mais detalhadamente, no próximo capítulo, que assemelhações entre alguns dos “governos fortes” - o de Getúlio Vargas e os fascismos - foram várias vezes empreendidas pelo artista.

Ocorre, em algumas crônicas, o fato do retrocesso representado pelo governo pós-1930 configurar-se em uma monarquia. Esta representação de um Vargas “imperador” ocorreu no primeiro semestre de 1934, quando ele dava mostras claras de que desejava prosseguir no poder ${ }^{180}$. Invariavelmente, de janeiro a maio, ele tornou-se o personagem dileto do humorista, apresentado chistosamente na maior parte dos escritos como “o chefe permanente do governo provisório”.

Belmonte criticava-lhe as contradições. Em 1930, Getúlio foi o líder de uma revolta que derrubou o governo precedente justamente porque o partido situacionista sempre conduzia, vitoriosamente, seus membros aos cargos políticos, desrespeitando, assim, as normas democráticas. Mas, em 1934, não apenas haveria a continuação do grupo revolucionário (ou pelo menos de parte dele ${ }^{181}$ ) na administração pública, como o presidente dava indícios de que permaneceria no poder executivo da Federação e, quase que certamente, por meio de eleição indireta.

A continuidade do mesmo indivíduo no cargo máximo do país ofereceu ao artista a possibilidade de fazer uma aproximação da política brasileira de sua contemporaneidade com o Império Brasileiro do século XIX, encabeçado inicialmente por Dom Pedro I.

E como a simples presidência, na sua rápida transitoriedade, 'não consulta ás nossas realidades', eu peço venia licença e permissão para, humildemente, apresentar uma idéia salvadora. A qual idéia, positivamente genial, é esta:

\footnotetext{
179 Cf. Nicolau Sevcenko. Orfeu Extático na Metrópole. São Paulo, sociedade e cultura nos frementes anos 20. São Paulo: Companhia das Letras, 2003.

${ }^{180}$ Cf. Edgard Carone, 1982; Robert Levine, 1980; Marly de Almeida Gomes Viana, 2007.

${ }^{181}$ Segundo Carone, o Tenentismo era um grupo político em decadência. Os seus elementos que permaneceram em destaque foram aqueles que terminaram por colaborar com as elites estaduais. Cf. Edgard Carone. A República Nova (1930-1937). 3 a edição. São Paulo: DIFEL, 1982, pp. 318-321.
} 
Proclamar-se o sr. Getúlio Vargas imperador, com o título de Getúlio I, defensor perpétuo do Brasil. ${ }^{182}$

Getúlio Vargas surge como uma paródia de Dom Pedro I não apenas devido ao título que lhe é oferecido (“defensor perpétuo do Brasil”), mas também porque ele é o primeiro "rei” de sua “dinastia” no país. Ademais, assim como o príncipe português que proclamou a Independência, Vargas igualmente prometia aos seus governados uma nova era, vista como um marco e indicadora de progresso e prosperidade. Outrora, houve um jovem rei. Agora, havia uma "gente nova” que se apoderou do poder e que se queria oposição dos “carcomidos”, legítimos representantes de uma república velha. Novamente, a história aparece em uma trajetória cíclica. Partindo de uma república “oligárquica”, a forma de governo brasileiro regrediu para uma monarquia, denominada - assim como no século anterior - por Império.

A posição aparentemente concordante do cronista com relação à "sagração" de Getúlio Vargas também diz respeito à concepção de governo própria de uma monarquia imperial. É indevido questionar a legitimidade do rei. Não se questiona, apenas se obedece.

Tanto no Brasil de Vargas como no caso do Império Brasileiro, permanece subentendido aos homens comuns que é arriscado se opor a esses tipos de regimes antidemocráticos; torna-se mais prudente “ser do amor” e acatar as decisões vindas de cima:

Enfim, como nós somos do amor, vamos concordar com os amigos de s. exa. Inauguremos a República hereditária, e, em tempo opportuno, proclamemos a Monarchia Espiritual Revolucionária. ${ }^{183}$

É interessante observar que, na transcrição acima, o cronista misturou dois regimes que se contrapõem - república presidencialista e reinado - criando, com isto, uma imagem de governo sue generis, porque completamente ilógica e oposta. Vemos uma república que é hereditária; e há uma monarquia revolucionária, ou seja, um regime que tem como paradigma a tradição, objetivando ao mesmo tempo a aceleração do tempo da história.

É impossível imaginar como isto se daria. Fazendo nossas as palavras de Belmonte, é caso de quem “já perdeu o juízo, e, agora, não há psychiatra que o encontre” ${ }^{184}$. Nesse sentido, o governo Vargas figura não apenas como um retrocesso, mas como modelo de irracionalidade absoluta.

\footnotetext{
182 Belmonte. A minha solução. Crônica publicada na Folha da Noite (São Paulo) em 19/01/1934, p. 2.

183 Belmonte. Esses amigos... Crônica publicada na Folha da Noite (São Paulo) em 18/04/1934, p. 2.
} 


\subsection{Ironia e Melancolia}

Nas linhas de Belmonte, os homens comuns são indivíduos melancólicos. Infelizes por terem de enfrentar diariamente a carestia, os ganhos baixos e a ameaça de desemprego, além da irracionalidade e dos desmandos do governo, completamente alheio a eles.

Muitas das crônicas do artista são marcadas pela melancolia, pois ele se sentiu traído e frustrado em sua esperança de mudança, que fora vigorosa no final dos anos 20. Belmonte e mais tantos outros homens das camadas médias, excluídos da política empreendida pelo PRP durante a Primeira República, ansiavam que com a ascensão do Partido Democrático de São Paulo aos cargos políticos (por meio da Aliança Liberal), conseguiriam finalmente exercer influência sobre seus representantes. Entretanto, logo após a vitória da Revolução, o PD foi colocado à margem e os políticos paulistas praticamente segregados do poder. Concomitantemente, as promessas de democratização da política brasileira se tornaram letra morta por vários meses, até a preparação para a eleição da Assembléia Nacional Constituinte, em 1932/33, e a Promulgação da Carta Constitucional, em 1934. Entretanto, ainda durante a elaboração da Magna Carta, parte considerável dos deputados paulistas se aproximara de Getúlio Vargas, outrora chamado pelos seus ânimos exaltados, especialmente durante a Revolução de 1932, de “dictador” e tirano.

As crônicas de Belmonte, portanto, transpiram amargura e melancolia porque houve uma ardente esperança em torno de um novo que, para as classes médias, não se cumpriu, foi frustrado em várias ocasiões: 1930, 1932 e em 1934.

Podemos nos perguntar se foi expressivo o número de paulistas das classes médias que sentiu frustração e amargura com relação à política daqueles anos. A resposta é sim, se pensarmos que o Partido Democrático era formado por setores das classes dominantes paulistas e das classes médias ainda que os membros desta, na maior parte dos casos, não figurassem nas posições de chefia do partido. E se pensarmos na entusiástica acolhida que a comitiva de Getúlio Vargas teve em São Paulo pelo povo paulistano, logo após a derrubada da Primeira República (24/11/1930) e, por outro lado, o vigor com que as camadas médias paulistas e paulistanas participaram do Movimento Constitucionalista de 1932, exigindo Constituição, Regime Legal e bradando “Tudo por São Paulo e pelo Brasil! ”, a resposta é novamente positiva.

A maior parte dos historiadores afirma que as classes médias acorreram com entusiasmo para a sustentação da Revolução Constitucionalista ${ }^{185}$, inicialmente empolgada pelas elites paulistas. Para

\footnotetext{
${ }^{184}$ Belmonte. A Confusão. Crônica publicada na Folha da Noite (São Paulo) em 18/06/1934, p. 2.

185 Cf. Richard Morse. Formação Histórica de São Paulo: de comunidade a metrópole. São Paulo: DIFEL, 1970. Cf. Maria Helena Capelato. O Movimento de 1932: a causa paulista. São Paulo: Brasiliense, 1981.
} 
o historiador Holien Gonçalves Bezerra, à época deste movimento, grande parte das classes médias paulistanas foram seduzidas pelo ideário liberal-democrático ${ }^{186}$ propalado por cafeicultores, industriais e pela imprensa de São Paulo. Nesse discurso, Getúlio Vargas e seu governo configuravam-se no Mal absoluto. Emergem expressões pesadas contra os políticos e apoiadores do Governo Provisório: insensatos, maus irmãos, tiranos, corruptos e mentirosos ${ }^{187}$.

Nas entrelinhas da excelente crônica "Port Tarrascon”, Belmonte compara a adesão dos paulistas à Aliança Liberal e a Getúlio Vargas, em 1930, com a história Tartarin de Tarascon, do escritor francês Alphonse Daudet (1840-1897), criador de grandes obras satíricas. Tartarin era um indivíduo alegre e imaginoso que vivia em Tarascon, um povoado do sul da França. Certo dia, um sujeito que se dizia duque, mas que na verdade não tinha título algum de nobreza - era um velhaco que vivia de trapaças - surgiu em Tarascon. Astuto, percebeu que poderia se aproveitar daquela gente, e foi logo dizendo aos tarasconeses que possuía uma belíssima e rica ilha no Arquipélago Malaio, e que tinha intenção de vendê-la. Falou maravilhas dela e, ao mesmo tempo, sugeriu que eles poderiam comprá-la. Empolgado com a oferta e com a possibilidade de mudança, o impulsivo e irreflexivo Tartarin foi o principal divulgador da terra do "duque", de modo que quase todo o povoado de Tarascon resolveu comprar alguns hectares da ilha. Como pagamento, o suposto aristocrata permaneceu com as moedas, as casas e as terras dos tarasconeses, que logo fizeram as malas e rumaram para a sua tão sonhada ilha. Partiram em dois navios. Mas eis o tragicômico desfecho da história de Daudet, narrada por Belmonte:

Uma leva chegou antes. Outra, depois. E, quando chegaram, desencadeou-se sobre todo aquelle povo, que vendera seus bens e abandonara suas terras, a mais cruciante desillusão que póde desabar sobre os homens. A terra maravilhosa, com sua cidade progressista, o seu porto, os seus monumentos, o seu commercio, a sua lavoura, a sua industria e o seu clima paradisíaco - era apenas uma ilha agreste, pantanosa e híspida, povoada por selvagens papúas que já haviam trucidado a primeira leva de emigrantes. A emigração festiva e esperançada estancou, pavida e horrorizada, ante esta acabrunhante realidade. Atirados, como destroços de um naufrágio, nessa ilhota

Cf. Edgard Carone. República Nova (1930-1937). São Paulo: DIFEL, 1982.

Cf. Holien Gonçalves Bezerra. O Jogo do Poder: revolução paulista de 32. São Paulo: Moderna, 1989.

Cf. Vavy Pacheco Borges. Memória Paulista. São Paulo: EDUSP, 1997.

${ }^{186}$ Trata-se sobretudo de democracia, estado de direito e liberdade de expressão. Cf. Holien Gonçalves Bezerra, op. Cit., pp. 68-69.

${ }^{187}$ Idem, p. 65. 
lutulenta e hostil, os tarrasconezes só tiveram olhos para ver, através da cortina de suas lágrimas, esse melancólico desmoronar de sonhos num recanto ignoto do oceano.

Não conheço, em literatura, nada tão profundamente dramático e amargurante. ${ }^{188}$

Logo após ter contado o terrível golpe do qual foram vítima os tarasconeses, que terminou por custar a vida de muitos deles, Belmonte discorre sobre os acontecimentos recentes da história nacional:

O Brasil, nestes últimos três annos, está vivendo instantes de intensa dramaticidade. O destino de quarenta milhões de seres está sendo jogado na mais impressionante partida de que há memória nos nossos annaes históricos. Há três annos que vimos lendo essa aventura amargurante, há três annos que vimos acompanhando os lances dolorosos desse drama sem par, dia por dia, numa sucessão de episódios cruciantes que deveriam encher de lagrimas os nossos olhos pávidos.

Entretanto, inexplicavelmente, sem saber porque, nós todos, tendo vontade de chorar, rebentamos em gargalhadas épicas!

Nós também, em 1930, compramos um 'Port-Tarrascon'.”189 [grifos nossos]

Todo o sentimento de tristeza e amargura frente ao que se acreditava ter sido uma traição da esperança do povo paulista está expresso nesta crônica. Os tarasconeses acreditaram no duque de Mons; os paulistas, nos líderes da Aliança Liberal, dentre os quais Getúlio Vargas.

Vale a pena realçar a forte relação estabelecida na crônica entre o sentimento melancólico e o humor. Ambos, é certo, foram estudados como interligados desde pelo menos o século XIX. Neste, o riso, mais especificamente a ironia foi apreciada e utilizada por alguns escritores românticos, entre estes, Karl Solger e Schlegel. Para Hegel, em sua obra Estética - A Idéia e o Ideal, a relação entre a melancolia e a ironia nasce da frustração do artista romântico perante a queda na realidade, que geraria uma lânguida tristeza e também uma reação irônica ${ }^{190}$. Percebe-se, na crônica de Belmonte, um sentimento melancólico originado da impotência frente a uma realidade desanimadora: se modificá-la parece estar além das possibilidades do homem comum, segregado dos negócios políticos e representado na crônica como “nós todos”, apenas resta-lhe rir da situação considerada absurda.

\footnotetext{
${ }^{188}$ Belmonte. “Port Tarrascon”. Crônica publicada na Folha da Noite (São Paulo) em 20/11/1933, p. 2. No livro Idéas de João Ninguém, p. 102.

${ }^{189}$ Idem, ibidem.

${ }^{190}$ Cf. HEGEL. Estética - A Idéia e o Ideal. São Paulo: Abril Cultural, 1974, pp. 141-143. Ver também o interessante artigo de Jaime Ginzburg, Conceito de Melancolia. In: Revista da Associação Psicanalítica de Porto Alegre, APPOA, v. 20, p. 102-116, 2001.
} 
O escritor não coloca São Paulo, especificamente, como vítima desta “aventura amargurante”, mas sim o Brasil. Ele alarga um sentimento de frustração mais especialmente paulista e paulistano para todo o país e para todas as classes sociais - quando sabemos que ele esteve presente, sobretudo, entre as classes dominantes e médias de São Paulo.

No início dos anos 30, São Paulo era considerado por parcelas de seus habitantes a região mais dinâmica do país, a mais rica, empreendedora e trabalhadora de todas as unidades da Federação e que, em 1932, chegou até a encetar uma batalha para restabelecer a "ordem" e o "progresso" ao Brasil, com a exigência da elaboração de uma Constituição. Além do mais, a totalidade da imprensa liberal e burguesa do estado considerava que apenas São Paulo sabia o que era bom para si e para o restante do país $^{191}$. Nesse sentido, podemos compreender porque o artista coloca as aflições paulistas para o Brasil como um todo.

Mas, com relação ao sentimento paulista de frustração, algumas das crônicas parecem querer nos dizer mais. Temos a impressão de que a traição contra os homens das camadas médias de São Paulo não partiu somente dos revolucionários outubristas. As linhas de Belmonte sugerem que prestemos atenção no comportamento dos deputados paulistas eleitos para a elaboração de uma nova Constituição para o Brasil, divididos no ano seguinte em Câmara dos Deputados e Senado, formando, assim, o Congresso Nacional ${ }^{192}$; que atentemos também para as atitudes do Interventor Armando de Salles Oliveira, instalado em seu cargo com o beneplácito do Presidente da República, no mês de agosto de 1933. Grande incentivador da luta dos paulistas em 1932, Salles se revelaria na Interventoria do estado um importante apoiador de Getúlio Vargas. Igualmente, este último foi conquistando o apoio dos políticos eleitos por São Paulo (1933), de sorte que, em 1934, muitos deles já haviam sido cooptados pelo político gaúcho e seu governo.

Percebe-se que os opositores do Presidente da República na Assembléia Nacional Constituinte/ Congresso Nacional tornavam-se cada vez mais minoritários. Logo, o reforço do esquema governamental - Vargas e elites situacionistas dos estados - tornará quase que pacífico o jogo político. A frente comum formada pelas forças situacionistas na Câmara Federal (1934-35) representa maioria esmagadora e, contra ela, só há a minoria parlamentar, que tem pequena representatividade, apesar de sua coragem. Ela era liderada principalmente por João Neves da Fontoura e Otávio Mangabeira ${ }^{193}$.

\footnotetext{
${ }^{191}$ Cf. Maria Helena Capelato. Os Arautos do Liberalismo. Imprensa Paulista (1920-1945). São Paulo: Brasiliense, 1989, pp. 30 - 34.

${ }_{192}^{19}$ Cf. Edgard Carone, op. Cit., p. 325.

${ }^{193}$ Idem, ibidem.
} 
Muitos dos deputados paulistas que se reaproximaram de Getúlio Vargas são aqueles oriundos do Partido Democrático que, em 24 de fevereiro de 1934, fundam o Partido Constitucionalista (PC) juntamente com outros grupos políticos menores, como a Federação dos Voluntários, a Liga de Defesa Paulista e a Ação Nacional, entre outros ${ }^{194}$. O PRP rompe definitivamente com o PD (já então Partido Constitucionalista), após inúmeros desentendimentos, em março do mesmo ano, e o motivo principal refere-se à rude declaração do Interventor Armando Salles dirigida aos perrepistas, que achincalhava a atitude hostil destes frente ao governo ${ }^{195}$.

Se em 1932 o Partido Democrático fora o memorável organizador da oposição ao Governo Provisório, no final do ano seguinte, seus deputados, na Assembléia, mostraram-se claramente mais amistosos ${ }^{196}$ com aquele do que os parlamentares do PRP.

Os deputados do Partido Democrático, eleitos em 1933 com uma marcante vitória e, principalmente, por meio dos votos das camadas médias paulistas ${ }^{197}$, cuja campanha esteve centrada na memória dos mortos da Revolução de 1932 e em seus ideais elevados ${ }^{198}$, assim como a eleição de outubro de 1934 para a Assembléia Estadual Constituinte, que dava a vitória ao PC, perceberam que seria tranquilamente possível permanecer no poder, desde que se acomodassem com o governo getulista. E este compreendera que com a vitória esmagadora da elite paulista nas urnas, em maio de 1933, era imperioso para a sua governabilidade se aproximar dela e, ao mesmo tempo, se distanciar dos Tenentes ${ }^{199}$ que, em meados de 1934, encontravam-se politicamente em franca decadência. Segundo o historiador Edgard Carone,

A realidade é que a passagem entre o estado de fato e o estado constitucional se faz no momento em que o tenentismo declina, mesmo quando certos representantes seus permanecem à frente de alguns Estados; por sua vez, as novas crises do Clube 3 de Outubro, com contínuas demissões de elementos de destaque, torna periclitante a existência da agremiação, até que em abril de 1935 o clube se dissolve. ${ }^{200}$

O astuto Getúlio Vargas percebera que seria um desgaste inútil apoiar-se no decadente Movimento Tenentista. Este serviu-lhe como base de sustentação no poder nos primeiros anos após o golpe de 1930. Agora, desorganizado e declinante, deveria ser substituído por forças políticas mais

\footnotetext{
${ }^{194}$ Cf. Edgard Carone, op. Cit., p. 327.

195 Idem, ibidem.

${ }^{196}$ Cf. Holien Bezerra, op. Cit., p. 98.

${ }^{197}$ Idem, p. 25.

${ }^{198}$ Idem, p. 21.

${ }^{199}$ Idem, pp. 21-23.

${ }^{200}$ Cf. Edgard Carone, op. Cit., pp. 325-326.
} 
coesas e dinâmicas, como parte das elites estaduais, especialmente a do grande estado cafeeiro. E o aspecto primordial é que os deputados paulistas do PD e o Presidente da República (além da sua entourage - ministros e demais assessores) almejavam, sobretudo, permanecer no poder e usufruir dele, nem que, para isso, tivessem que encetar uma convivência cordial entre $\mathrm{si}^{201}$. E nem que, para isso, nos idos de 1934-35, a elite paulista colocasse a perder seu discurso favorável ao Movimento de 1932, onde havia:

...a criação do mito de um São Paulo liberal que se insurge contra os desmandos da ditadura. O mito liberal é mantido enquanto interessa à consolidação da burguesia perante o 'governo dos tenentes', mas logo é abandonado quando seu preço se apresenta politicamente muito alto. ${ }^{202}$

Os parlamentares paulistas se viram obrigados a esquecer seu repetitivo palavrório democrático-liberal, porque seu discurso se chocaria com as atitudes pouco democráticas do governo, e revelariam, por fim, a aberrante contradição, pois tanto Getúlio Vargas quanto a alta patente do Exército davam mostras evidentes de que desejavam se sobrepor à Constituição de $1934^{203}$.

E para Edgard Carone, este compromisso entre forças políticas diversas (governo e Interventor/ bancada parlamentar paulista) sofrerá algumas modificações apenas com o surgimento do Estado Novo - e após mais de três anos de ininterrupta sustentação:

Depois de se consolidar no Estado, a oligarquia paulista do Partido Democrático tenta retorno à política dos grandes Estados, com o lançamento da candidatura de Armando de Salles Oliveira à presidência da República (1937). O golpe de Estado dado por Getúlio Vargas é que impede a sua vitória e permite o afastamento do poder do grupo do Partido Democrático.

Os novos grupos oligárquicos de São Paulo não têm tempo material para se consolidarem. O que o Estado Novo faz é alijá-los temporariamente do poder político, mas conserva-se toda a estrutura social do fenômeno coronelismo-oligarquias. ${ }^{204}$

Para grande parte dos deputados paulistas aliados de Armando de Salles Oliveira, o discurso constitucionalista terminou descartado, preterido frente à possibilidade de se encastelarem no poder. O Interventor de São Paulo foi um dos primeiros a olvidá-lo. Em agosto de 1933, quando o

\footnotetext{
${ }^{201}$ Cf. Holien Bezerra, op. Cit., p. 98.

${ }^{202}$ Idem, p. 66.

${ }^{203}$ A Lei de Segurança Nacional de abril de 1935 foi uma dessas mostras.

${ }^{204}$ Cf. Edgard Carone, op. Cit., p. 166.
} 
incentivador dos soldados constitucionalistas de antanho visita Getúlio Vargas, recebe deste a notícia de que lhe seria atribuída a Interventoria do rico estado cafeeiro. Mas, em contrapartida, o presidente se considera indicado pela Chapa Única ${ }^{205}$ para a sua reeleição, que seria votada no ano seguinte. E ele foi reeleito com tranqüilidade, posto que os legisladores do PD/PC o apoiaram largamente.

Os ódios cultivados entre os legalistas de 1932 e a “dictadura” pareciam fazer parte de um passado longínquo; mas Belmonte, assim como parcelas das classes médias paulistas, sobretudo os jovens que se engajaram nos campos de batalha durante a Revolução Constitucionalista ${ }^{206}$, se recusavam a descartar o ideário democrático-liberal. Afinal, não fora para regenerar a república e a moral política que se fez uma revolução em 1930? E em 1932, ainda com o intuito de glorificar as idéias liberais para a "grandeza de São Paulo e do Brasil”, o povo paulista se sacrificou doando suas economias, suas alianças de casamento, costurando noites adentro e lutando, sendo que quase mil vidas foram perdidas ${ }^{207}$.

Depois de todos esses esforços, foi frustrante para parte dos homens das classes médias observar que os políticos paulistas, outrora muitos deles organizadores da Revolução Constitucionalista, colaboravam com o governo getulista e viravam as costas para aqueles que os elegeram em 1933 e 1934. Holien Bezerra expõe esses acontecimentos em uma síntese:

A burguesia paulista, portanto, ao se utilizar da revolução e do discurso revolucionário para retomar o poder político, não está preocupada com a coerência de seus princípios (...). Simplesmente e em última instância, trata-se de retomar o poder. Se o caminho para isso for uma recomposição com o grande inimigo da véspera, ela é feita sem hesitação; se necessário, à revelia dos princípios outrora defendidos tão intransigentemente. Estabelece-se, assim, a partir de fins de 1933, entendimentos e colaboração entre Getúlio Vargas e a classe dominante paulista (...). Nessas aproximações e recomposições, a concepção de sociedade e de Estado defendida pelos liberais perde a sua identidade. As atitudes autoritárias recrudescem a partir do final de 1934, com os aplausos e o apoio do governo paulista e das associações das classes conservadoras. $^{208}$

Na crônica Disciplina Partidária, de 07/03/1934, Belmonte zomba ao mesmo tempo em que critica as colocações do Interventor Armando Salles, que condenara com veemência a existência de vários partidos políticos no estado de São Paulo. Ele propugnava pela preponderância de apenas um

\footnotetext{
205 À época formada pelo PRP e, majoritariamente, pelo PD.

${ }^{206}$ Cf. Holien Bezerra, op. Cit., pp. 96-97.

${ }^{207}$ Cf. Jeziel de Paula, op. Cit.

${ }^{208}$ Idem, p. 97-98.
} 
deles, o PC - logicamente, o seu próprio partido. Munido destas informações, o escritor o compara com o antidemocrático e - declaradamente - pró-fascista General Góes Monteiro:

Há poucos dias, concedendo mais uma de suas exuberantes entrevistas, o bravo general P. Góes affirmou que o Brasil 'precisa ser disciplinado, por bem ou por mal'. E hontem, o sr. Armando de Salles Oliveira, respondendo á saudação que lhe foi feita pelo Partido Constitucionalista, pensou pela cabeça do loquaz ministro da Guerra, quando assegurou que o mundo se debate nas pontas de um dilemma: o despotismo de uma pessoa ou o despotismo de um partido.

O ex-commandante dos Exércitos de leste de 32 não esclareceu de que modo se processaria á disciplina deste povo bohemio. Mas o sr. Interventor em São Paulo opinou que essa disciplina só póde ser feita pelo despotismo de um partido. ${ }^{209}$

Belmonte aponta a farsa de Armando Salles: Como um indivíduo que sempre se qualificou como democrata podia agora se pronunciar a favor da predominância de apenas uma agremiação política? O artista prossegue suas linhas com o intuito de sublinhar as contradições do Interventor paulista e dos políticos do Partido Constitucionalista que, havia alguns poucos anos, tinham cerrado fileiras em torno do PD e consideraram-se os paladinos do ideário democrático-liberal. No entanto, depois de instalados no poder, tomavam atitudes semelhantes àquelas adotadas pelos políticos da Primeira República, explicitadas como o avesso da democracia:

Eu creio que antes da revolução de 1930, o que havia no Brasil, e principalmente em S. Paulo, era exactamente a disciplina partidária. Quem pensava por todos nós, era exclusivamente o P.R.P (...). Embora o paíz, durante esse longo período, prosperasse e attingisse um alto grau de civilização, as pessoas que hoje compõem o Partido Constitucionalista não gostaram da brincadeira e, alliando-se de corpo e alma - mais de alma do que de corpo - aos revolucionários, mandaram a disciplina pentear macacos, implantando no paíz um regime pré-anarchico que nos tem enchido de cabellos brancos.

Ora, é forçoso convir que há, nisso tudo, uma trapalhada épica. Se em 1929, esses excellentes cidadãos não se cansavam de preconizar a necessidade de vários partidos, investindo furiosamente contra a disciplina do P.R.P., é singularmente estranhável que hoje, decorrido tão curto lapso de tempo, venham Suas Excellencias afirmar

${ }^{209}$ Belmonte. “Disciplina Partidária”. Crônica publicada na Folha da Noite (São Paulo) em 07/03/1934, p. 2. 
exactamente o contrario, dizendo que o paíz só poderá gosar os benefícios da ordem e do progresso, se todo o mundo se alistar num único partido. ${ }^{210}$ [grifos nossos]

Se de 1931 até, aproximadamente, 1933, o artista se simpatizara com o PD paulista e considerava-o posicionado no pólo oposto daquele dos revolucionários getulistas, apresentando-o como uma agremiação de democratas legítimos, a partir do momento em que muitos de seus membros passaram a cooperar com o governo, sob a pena de Belmonte, se equipararam com ele e concordaram com seu autoritarismo. Daí a ironia dirigida aos filiados do Partido Constitucionalista, denominados, na segunda linha do segundo parágrafo transcrito, de "excellentes cidadãos”.

Nesse sentido, o Interventor e os políticos do PC foram, progressivamente, se equivalendo aos demais revolucionários de 1930 - Getúlio Vargas, José Américo, Antonio Carlos, General Góes Monteiro e General Rabelo, entre outros - e dividindo com eles a pecha de enganadores do povo. E também, é claro, a de autoritários, inimigos da liberdade de expressão.

Desse modo, os paulistas, que se consideravam os gloriosos condutores do Brasil (de antanho), terminaram submetidos pelos ditames da "Pátria amada” (leia-se: Governo da Federação), que não admite divergências de opiniões:

\begin{abstract}
Não sei se estou sendo convenientemente claro, mas creio que o que se pretende realizar em São Paulo, é o predomínio, ou melhor, o domínio de um único partido. Todos nós, brancos, pretos e mulatos, só seremos differentes na dermochromia; por dentro, é de mister que sejamos eguaisinhos, pensando do mesmo geito, sentindo do mesmo modo. Quem pensar de modo differente, quem tiver uma idéa que não seja a idéa imposta pelo partido, faça o favor de calar o bico e não piar, porque a Pátria amada não admitte dissidências. ${ }^{211}$ [grifos nossos]
\end{abstract}

Assim como este parágrafo transcrito acima, os três últimos da crônica desmascaram por completo os políticos de São Paulo. Para isso, Belmonte não utiliza apenas a ironia, o recurso cômico mais usado em seus escritos. Com o intuito de estampar o quão absurdos tornaram-se os discursos e as intenções dos constitucionalistas, ele lança mão da lógica para escancarar as contradições existentes entre suas propostas passadas e as atuais:

Não pergunto se essa these é certa ou errada. Não pergunto nada desta vida. Mas peço licença para ponderar que, sendo assim, a revolução de 1930 não passou de um

\footnotetext{
${ }^{210}$ Idem, ibidem.

${ }^{211}$ Idem, ibidem.
} 
'lamentável equívoco', pois destruiu uma ordem de cousas que estava certa, para implantar um regime que está completamente errado. Ora, se são os próprios revolucionários de 1930 que dão inteira razão ao P.R.P., por este ter exercido longamente o seu poderoso despotismo partidário, isso quer dizer que o P.R.P. estava cumprindo galhardamente o seu dever e os revolucionários praticaram um acto de mais gritante impatriotismo quando impediram que esse partido continuasse a exercer a sua obra disciplinadora.

Nesse caso, não há outra solução: vamos repor o P.R.P. onde ele estava, peçamos-lhe desculpas e vamos nos alistar em massa nas suas fileiras.

É isso que se infere desse estranho trecho do discurso do interventor. Salvo que eu, quando o li, estava sonhando... ${ }^{212}$ [grifos nossos]

Em outra crônica, intitulada A Dictadura Partidária, de 07/08/1934, Belmonte volta a fazer críticas ao Interventor de São Paulo pelo mesmo motivo; este defende a predominância de um único e poderoso partido, de modo que haja continuidade administrativa.

Logo nas primeiras linhas, Belmonte zomba dos pronunciamentos de Armando. Trata-se de quando o artista afirma, jocosamente, que "nesse momento complicado de nossa vida política, em que toda a gente anda por ahi fazendo grosso alarde de suas convicções partidárias, eu reservei-me o direito de conservar-me 'acima dos partidos', governando discricionariamente este canto de página” ${ }^{213}$.

O interventor declarara, em um recente discurso realizado na cidade de Ribeirão Preto, que "só a existência de um grande partido, de directrizes definidas, poderá assegurar a continuidade de administração, sem a qual os mesmos erros poderão ser repetidos” ${ }^{214}$. Com o intuito de desqualificar as idéias de Salles, novamente o escritor procura sublinhar-lhe a falta de coerência política, discorrendo sucintamente sobre a trajetória dos dois (dele e do interventor) e comparando-as, tendo como limite o final dos anos 20 até o seu presente, meados da década seguinte:

(...) Vamos dar um salto no tempo e ver o que occorria por estas bandas nos tempos em que o P.R.P. era o dono da casa.

Nesse tempo longínquo, havia aqui, como todos nós sabemos, 'um grande partido' que era o supra-citado P.R.P. E o supra-citado P.R.P. também affirmava a necessidade da sua existência, exactamente porque era imprescindível haver 'continuidade administrativa'.

\footnotetext{
212 Idem, ibidem.

${ }^{213}$ Belmonte. “A Dictadura Partidária”. Crônica publicada na Folha da Noite (São Paulo) em 07/08/1934, p. 2.

${ }^{214}$ Idem, ibidem.
} 
Mas, como os senhores devem lembrar-se, nós todos achamos ruim aquela justificativa. Gritávamos contra o P.R.P.; e, gritando, dissémos que a democracia não podia tolerar a existência de um único partido, porque isso importaria no advento de uma dictadura partidária; e que, para evitar-se essa calamidade social, devíamos crear outros partidos, igualmente fortes, afim de que todos se revezassem no poder. E fundou-se então o Partido Democrático, do qual faziam parte o honrado senhor Salles Oliveira e o não menos honrado autor destas linhas.

Mas, com o correr dos annos, e com as reviravoltas que o mundo deu, o senhor Salles Oliveira foi para o governo e eu não fui. Resultado: o senhor Salles Oliveira mudou de idéa. Mas eu não mudei.

Já num discurso anterior, o honrado senhor Salles Oliveira se referia á necessidade da 'dictadura de um partido' (...). Segue-se que s. exa. está fazendo, sem o perceber, uma vasta propaganda do P.R.P. - pois o que s. exa. preconisa, para a salvação da administração pública, é uma coisa que, em linguagem política, se chamava 'perrepismo'. Como se explica, pois, que o honrado senhor Salles Oliveira, disposto, como está, a consolidar o seu grande partido, tente fazer uma coisa que s. exa., como democrático, combateu no adversário ${ }^{215}$

Expostas por Belmonte, as atitudes de Salles Oliveira, se comparadas com as do artista, denunciam-no como embusteiro, pois fizera parte da oposição, no PD, até enquanto as vias para o poder permaneceram-lhe inacessíveis. Mas, após a possibilidade de se imiscuir nelas, ele se acomodou tranquilamente com os inimigos de outras épocas. E, por outro lado, a defesa de um partido predominante aproximavam-no da práxis do PRP, que ele tanto condenara no final dos anos 20. Já Belmonte, assim como parte dos paulistas comuns, permanecera com seu ideal democrático; não acompanhou o Partido Democrático, transformado em Constitucionalista em fevereiro daquele ano, na escalada aos cargos administrativos, distribuídos cuidadosamente pelo Governo Provisório. Salles, por sua vez, foi contemplado com a Interventoria de São Paulo. Na mesma transcrição (linhas 12 e 13) Belmonte relata que fizera parte do Partido Democrático. Mas, ao contrário de Salles, ele jamais se bandeou para o lado do governo e nem modificou seus ideais democráticos.

No final da crônica, o artista novamente estabelece uma distância entre suas atitudes e aquelas do interventor paulista que, sem titubear, passara a apoiar um governo nada democrático (afinal, este permitira a transformação da Assembléia Nacional Constituinte em Congresso Nacional ${ }^{216}$, elegera

\footnotetext{
${ }^{215}$ Idem, ibidem.

216 “A Assembléia Nacional Constituinte se transforma em Assembléia Ordinária, dividindo-se em Câmara dos Deputados e Senado, formando o Congresso Nacional. Repetindo o golpe dado pela Assembléia Nacional Constituinte
} 
indiretamente o Presidente da República pelo voto dos parlamentares ${ }^{217}$, e impunha a censura para a imprensa de todo o país), cujo pensamento e atitudes o aproximariam do PRP, partido soberano da república anterior.

\begin{abstract}
Mas, como eu, há tempos combati a 'dictadura partidária’ do P.R.P., peço vênia, licença e permissão para combater todas as dictaduras partidárias que apareçam por ahi, eis que, apesar dos pesares ainda não adheri aos ideaes do general P. Góes. Ou somos uma democracia, ou somos uma dictadura. Pão, pão, queijo, queijo (...). Não foi para isso que nós fizemos uma revolução em $1930{ }^{218}$
\end{abstract}

Esta crônica de Belmonte publicada no jornal em agosto de 1934, onde ele critica a traição dos filiados do Partido Constitucionalista aos ideais democráticos e seus acordos com o governo, apresentava-se na ordem do dia. Afinal, as eleições de outubro de 1934 para a Assembléia Estadual Constituinte aproximavam-se, e as ações do PC no sentido de assegurar seu predomínio político no estado aprofundavam-se. Após o rompimento da Chapa Única, em fevereiro daquele ano, a luta do Partido Constitucionalista pelo poder estadual, segundo Carone, não veio desacompanhada de inúmeras pressões:

\begin{abstract}
A partir de então, os perrepistas são afastados dos empregos públicos, sendo perseguidos, pois Armando de Salles "vai impedir que continue a infiltração de elementos adversários, que, de muito, vêm embaraçando a sua ação”. Afinal, em 14 de outubro, organização e pressão levam à vitória do Partido Constitucionalista, com 34.015 votos, enquanto o PRP obtêm 25.506” 219
\end{abstract}

Das duas crônicas analisadas, podemos auferir que, para o artista, as máscaras do interventor e dos deputados caíram. A bandeira democrática que empunharam contra a Primeira República e, posteriormente, contra o Governo Provisório, tratou-se apenas de um recurso para arrebatarem o poder político. Compreendendo, em 1933, que ao encetar acordos com Vargas poderiam permanecer tranquilamente e sem sobressaltos em seus cargos, buscaram firmá-los sem delonga. O abandono dos

de 1891, a atual foge à lei específica de 1933, que determina somente eleições para deputados à futura Constituinte, dissolvendo-se após a promulgação da Carta Magna”. Cf. Edgard Carone, op. Cit., p. 325.

217 O congresso, em sua esmagadora maioria, apenas ratificou pelo voto a permanência do mesmo indivíduo na Presidência da República.

${ }^{218}$ Idem, ibidem.

${ }^{219}$ Cf. Edgard Carone, op. Cit., p. 328. A citação presente no parágrafo transcrito foi adquirida pelo historiador por meio dos discursos do interventor paulista. Cf. Armando de Salles Oliveira. Discursos. São Paulo, 1935, página nãoidentificada. 
ideais democráticos, outrora enfaticamente defendidos por eles, foi empreendido, e sem encabulamentos.

Observadoras e comentadoras do imbricado jogo político que se desenrolava, as crônicas de Belmonte expressavam o desapontamento de parcelas dos paulistas comuns perante as atitudes de seus supostos representantes, que mostravam a eles a importância do fim - em detrimento dos meios -, a participação no poder.

O sentimento de desconfiança referente aos deputados que foram eleitos no pleito de 03 de maio de 1933 está presente na crônica Coisas do Brasil, de 28/02/1934. À época, Getúlio Vargas intentava manobrar a Assembléia com o objetivo de ser reeleito antes da redação final da Constituição e da sua promulgação. Com a aproximação política que ocorria entre o interventor de São Paulo (líder do Partido Constitucionalista) e o Presidente da República, as linhas de Belmonte sugerem algum receio de que os parlamentares do PC fossem pressionados pelo seu partido a apoiar a “inversão do trabalho da Assembléia”, ou seja, primeiro votariam a reeleição do cargo executivo e só depois prosseguiriam com a elaboração da Carta para o país. E o temor do artista de que os deputados fossem incentivados pelas suas respectivas agremiações políticas a atentar prontamente para a reeleição do presidente não permanecia circunscrito apenas aos limites de São Paulo, mas expandiase para os demais estados do Brasil. Acompanhemos este interessante escrito:

Ainda hontem aconteceu um episódio assim: um deputado chegou á Constituinte, tomou fôlego, pediu a palavra e falou.

Falou exuberantemente, cheio de patriotismo, de indignação e de suor. Contou esse egrégio congressista que, tendo percorrido o seu Estado, há poucos dias, de um extremo a outro, pudera constatar a revolta que lavrava no seio do povo, devido ao golpe que se preparava para a inversão dos trabalhos da Assembléia e conseqüente eleição do Presidente da República.

Rubro de cólera, com os lábios a tremer de sacratíssima fúria, o collendo congressista contou que, em certo lugar, um eleitor, mais furioso e mais patriota que os demais, estava na imminencia de rasgar seu título quando elle, orador, interveio dramaticamente, exclamando como no $3^{\circ}$ acto de um drama patriótico:

- Não! Não façais isso! Os constituintes não votarão a inversão dos trabalhos, eu vol-o juro! Isso seria uma indignidade!

O eleitor patriota, com lágrimas nos olhos, cahiu nos braços do orador:

- Não rasgarei meu título senhor! Nós confiamos em vós!

E estava o esfogueteado orador nesse ponto do seu discurso, quando o líder de sua bancada aparteou-o: 
- Não se esqueça que v. exa. tem compromissos partidários...

O orador não se perturbou. Empinou o busto altivo, ergueu a fronte inspirada, estendeu um braço viril e bradou:

- Estou defendendo o ponto de vista do nosso partido que, de certo, é contrário á inversão. Mas se o partido resolver apoiar essa inversão, eu... (aqui meu heróico leitor já está fremindo de enthusiasmo cívico e com as mãos espalmadas promptas para applaudir. A Assembléa, e o citado líder, pelo menos, ficaram com os nervos tinindo, nessa altura!)

- ...mas se o partido resolver apoiar essa inversão, eu, como político disciplinado, acompanharei o meu partido!

Eu só queria vêr, depois disso, a cara daquelle originalíssimo eleitor que queria estraçalhar o seu título...

E ainda existem por ahí uns cidadãos cégos e surdos que vivem a falar mal da Republica velha... ${ }^{220}$

A República Nova apresenta-se tão pouco democrática quanto a Primeira República, colocada pelo autor como República “Velha”. Na prática, os cidadãos continuam sem representatividade política, assim como ocorria antes de 1930. Logo, compreende-se a intenção do eleitor em rasgar seu título. Se ele não servia como passaporte para a participação política, era um simulacro desta e, como tal, perdera sua utilidade original; podia-se, portanto, reinventar seu uso, resultando sua destruição física em um protesto político.

Ainda que Belmonte não tenha denominado em sua crônica o estado (região) em que os populares mostraram-se profundamente decepcionados com a possibilidade da inversão dos trabalhos da Constituinte (que era o mesmo do eleitor que objetivava estraçalhar seu título), sugerimos que São Paulo insere-se como o mais provável. As linhas do escrito sublinham o apego daquela gente à democracia e, concomitantemente, a sua absoluta inconformidade com a inversão que ameaçava processar-se, acompanhada de um sentimento de revolta. À época, eram divulgadas com certa constância nas crônicas e editoriais da Folha da Noite as características do "povo" paulista: naturalmente legalista e democrata. Fiel ao espírito de 1932, muito se decepcionaria caso o processo de constitucionalização do país fosse ultrajado.

\footnotetext{
${ }^{220}$ Belmonte. Coisas do Brasil. Crônica publicada na Folha da Noite (São Paulo) em 28/02/1934, p. 2. No livro Idéas de
} João Ninguém, pp. 153-155. 
Tanto nos editoriais como também para o artista, o povo paulista configurava-se sempre como o defensor da legalidade. É isso que podemos apreender em um dos parágrafos de A toda pressa!, publicada a 22/02/1934:

Quando, há mais de dois annos, se falava na reconstitucionalização do paiz e dizia-se que, sob o regime legal, haveria 'maior autoridade', 'maior estabilidade e confiança no poder', 'tranquillidade para o espírito público', 'termo ás agitações', 'paz política', 'regularização mais efficiente dos serviços públicos’, 'maior dignidade para a nação’ (...) os eminentes homens da Republica nova mandavam a opinião publica esperar, porque elles estavam muito occupados. E foi preciso que São Paulo empunhasse armas, escrevendo a epopéa de 1932, para que os detentores do 'espírito revolucionario' abandonassem o regime de despistamentos e marchassem para a legalidade. ${ }^{221}$ [grifos nossos]

Percebe-se a expressiva desconfiança que pairava sobre os parlamentares naquele período, presente em algumas das crônicas de Belmonte. Ainda que saibamos que a Assembléia não acatou a reeleição do Presidente da República antes da promulgação da Magna Carta, pois a inversão desse processo resultaria em uma completa perda da sua credibilidade perante a opinião pública ${ }^{222}$, é sintomático que o artista tenha escolhido a crônica em questão - Coisas do Brasil - para compor seu livro Idéas de João Ninguém. Belmonte parecia possuir o anseio de deixar para a posteridade a impressão de que a Assembléia Constituinte de 1933, escolhida pelos eleitores ${ }^{223}$, revelara-se uma enganação, frustrando, em grande parte, a participação política dos homens “comuns”224, generalizados na palavra “povo”.

Assim como observamos em "Port-Tarrascon”, a crônica Coisas do Brasil também relaciona intimamente o humor e a ironia com o sentimento de desalento e de melancolia.

Percebeu-se, há muito, que Belmonte considera a política pós-1930 um indubitável desastre. Por outro lado, na sua concepção, é ela que o faz rir e lhe oferece a deliciosa oportunidade de fazer os outros rirem, por meio do desvelamento de suas contradições, inversões e falta de lógica. É uma

\footnotetext{
${ }^{221}$ Belmonte. A toda pressa! Crônica publicada na Folha da Noite (São Paulo) em 22/02/1934, p. 2. No livro Idéas de João Ninguém, pp. 153-155.

${ }^{222}$ A Constituição foi posta em vigor a 16 de julho de 1934. A reeleição indireta de Getúlio Vargas deu-se no dia seguinte. Cf. Edgard Carone, op. Cit.

${ }^{223}$ Segundo o Código Eleitoral promulgado em fevereiro de 1932, tinham direito ao voto aqueles que fossem alfabetizados, o que reduzia grandemente o número de eleitores brasileiros. Se o trabalhador rural era, em sua maioria, desconhecedor das letras e, se parte do operariado também o era, a participação eleitoral permanecia restrita, basicamente, às elites brasileiras e às camadas médias urbanas.

${ }^{224}$ Homens "comuns”, nesse caso, seriam os indivíduos originários de parte do operariado e, especialmente, das classes médias, uma vez que parcela considerável da população brasileira encontrava-se excluída do direito de voto.
} 
pretensa democracia que se revela uma ditadura, uma esperança que se transforma em farsa; é um rompimento que configura-se numa continuidade ${ }^{225}$, quando não em um retrocesso.

É apenas nesse sentido que podemos compreender determinadas linhas do artista que, aparentemente, elogiam algo na República Nova. Em verdade, não é ela valorizada, mas sim seus absurdos que, da mesma forma que podem conduzir à aflição, flertam igualmente com o riso. Já se disse que o humor, na maior parte dos casos, “...é a polidez do desespero. É um exercício de alta voltagem que consiste em fazer-se de malandro à beira do abismo, do nonsense” ${ }^{226}$. Este aspecto ambivalente do humor é muito bem explorado no início da crônica, antes da narração das desventuras do inconformado eleitor e do deputado:

...Não, meus amigos, este país é, positivamente, do outro mundo! As geographias affirmam que elle se acha situado na América do Sul, num planeta chamado Terra, mas isso deve ser pilhéria de mal gosto.

Principalmente agora, depois que a 'arrancada regeneradora' varreu o paiz para 'sanear' os nossos costumes, eu estou cada vez mais inabalável na serena convicção de que nós vivemos na Lua, em Marte, no Sol...

Na Terra é que não póde ser (...)

Ninguem póde se espantar com as coisas excêntricas que acontecem porque, mal a gente depara um, não tem tempo de arregalar os olhos e escancarar a bocca porque, logo em seguida, surge outro. Nós vivemos, nesta República pinturesca, num perpetuo 'motu-continuo de disparates'. Eu dou graças aos céos, por ter encontrado, enfim, qualquer coisa que me faça rir. Esta, sim, é a Republica dos meus sonhos... ${ }^{227}$ [grifos nossos]

Um governo tão atribulado, em que as pessoas sequer têm tempo para se espantar com suas inúmeras e sucessivas atitudes disparatadas, só pode, em alguma medida, ser útil ao profissional do humor. Evidentemente, com o revirar da lógica perpetrado pela República Nova, o humorista encontra, sem esforço, farta temática para suas crônicas. É desta forma que podemos compreender

\footnotetext{
${ }^{225}$ Não é verdade que não houve quaisquer mudanças no Brasil. Lembremos que, no plano social, cresciam as cidades e suas atividades econômicas, em especial a industrialização, e a população de origem imigrante tornava-se muito expressiva. No plano político, o executivo federal impunha progressivamente a centralização sobre os estados e, logo após a Revolução de 30, foi criado o Ministério do Trabalho, Indústria e Comércio. Houve também a nomeação de interventores para os governos estaduais. Mas, possivelmente, essas mudanças empreendidas pelo governo Vargas não agradaram a Belmonte.

${ }^{226}$ Cf. Georges Minois. “O Século XX, morrer de rir”. In: História do Riso e do Escárnio. São Paulo: Editora UNESP, 2003, p. 566.

${ }^{227}$ Belmonte. Coisas do Brasil. Crônica publicada na Folha da Noite (São Paulo) em 28/02/1934, p. 2. No livro Idéas de João Ninguém, p. 153.
} 
essas colocações de Belmonte: “Eu dou graças aos céos por ter encontrado, enfim, qualquer coisa que me faça rir. Esta, sim, é a República dos meus sonhos.”: Em uma época onde encontrar trabalho estava difícil devido, em grande parte, ao abalo que a crise de 1929 provocou na economia brasileira, o único que permanecia “sossegado” ante o "ganhar a vida” era o humorista da Folha da Noite, pois a República Nova garantia-lhe assunto à vontade.

Os escritos expressam o desencanto para com as atitudes dos parlamentares por todo o ano de 1934, assim como com relação ao interventor paulista. Eles se aproveitaram da esperança das classes médias para ascender aos seus cargos; lá instalados, simplesmente se apartaram dos eleitores, como se mais nada lhes devessem. Logo, segundo Belmonte, processava-se uma inversão do propósito legal do governo, assim como ocorrera na Primeira República.

Os editoriais da Folha da Noite, por sua vez, tendiam a prestar apoio aos legisladores paulistas eleitos em 1933 e ao interventor de São Paulo, o que divergia das críticas do cronista. E se, eventualmente, eles direcionavam algumas críticas aos parlamentares ou a Salles Oliveira, estas assumiam um tom respeitoso, de aconselhamento. Não eram corrosivas. Nas páginas do periódico, os representantes paulistas constituíam, na maior parte das vezes, uma impoluta minoria parlamentar opositora. Por outro lado, os deputados de outros estados - Rio Grande do Sul, Rio de Janeiro, Paraíba, Ceará, Pará - eram acusados de oferecer sólido apoio ao “dictador” e ao seu governo, voltando-se, assim, contra os interesses do “povo” brasileiro.

Como convinha a um arauto do liberalismo, a Folha não denegria a imagem dos representantes de seu estado, fossem estes fazendeiros ou até industriais, mas, de qualquer modo, estreitamente imbuídos do ideário liberal.

É necessário esclarecer que as crônicas que criticam as atitudes de Armando de Salles Oliveira e o Congresso não representam a maioria das obras de 1933-35 ou parte considerável delas. Em verdade, trata-se de uma quantidade bastante modesta. Belmonte evitou hostilizar com freqüência o interventor paulista e os deputados. E quando ria do parlamento e de suas afirmativas perante as seduções do poder, raramente apontava os nomes dos políticos.

Mas, ainda que em pequeno número, estes escritos nos ajudam a compreender o porquê da repetição do posicionamento de desencanto presente na obra do cronista. Outubro de 1930 permanecia um tanto distante no tempo para impulsionar a amargura constante. Suspeitamos que as crônicas, olvidadas nas segundas páginas do velho jornal, queriam dizer algo mais sobre aqueles tumultuados anos de 1932-35.

Os inimigos contra os quais Belmonte dirigia a maior parte de suas linhas sempre foram Getúlio Vargas e os políticos que, em 1930, ascenderam com ele: General Góes Monteiro, General Rabello, José Américo, Antonio Carlos e Oswaldo Aranha. Entre todos eles, Getúlio Vargas ganhava 
destaque especial, pois, como chefe revolucionário e presidente da República, representava, com maior evidência, o governo pós-Primeira República.

De qualquer modo, dada a freqüência dos sentimentos de traição e desencanto nas crônicas de Belmonte, que desembocavam constantemente em uma literatura melancólica - ainda que ao mesmo tempo humorística -, incorreto seria se os relacionássemos somente às frustrações de 1930 e à derrota da revolução paulista. Alguns dos escritos querem nos dizer mais, sugerem que a decepção prosseguiu nos anos seguintes e ela foi provocada, em parte, por aqueles de quem mais se esperou mudanças após 1932: os representantes políticos do povo paulista.

Faz-se premente lembrar que a exposição dos sentimentos de traição e desencanto não foi atitude exclusiva de Belmonte. A sociedade paulista e paulistana estava mergulhada neles, e isto se torna claramente perceptível quando da leitura de bibliografia voltada para o estudo dos jornais liberais e burgueses de São Paulo ${ }^{228}$, com a leitura dos editoriais da Folha da Noite e das centenas de livros escritos por ex-combatentes da guerra de $1932^{229}$. A peculiaridade da obra de Belmonte não está, certamente, no “que se critica”, mas, sim, em “como se critica”. Há em suas crônicas inúmeras associações do novo governo revolucionário com a modernidade (sobretudo a modernidade técnica, outra bela promessa frustrada) e com o Nazi-fascismo, que acreditamos, sem embargo, se tratarem de temáticas com relações instigantes e originais.

As crônicas que se referiam ao governo Vargas como o avesso daquilo prometido pela revolução foram mais numerosas durante 1934 e o início do ano seguinte. Afinal, em 1934, destacaram-se acontecimentos novos que colocaram em efervescência o Governo Provisório e a República Nova e parte da opinião pública. Houve a eleição indireta de Getúlio Vargas, a transformação da Assembléia Nacional Constituinte em câmara ordinária, e, em outubro, a eleição para deputados estaduais. Indubitavelmente, os primeiros meses de 1935 transpiravam tensão e incertezas, uma vez que a discussão de uma Lei de Segurança Nacional que seria colocada em vigor em abril daquele ano, e que evidenciava a sanha autoritária do governo, a fragilização da Constituição e, consequentemente, da democracia brasileira. Houve também, em 1934, escritos de Belmonte cuja temática central esteve focada na rejeição ao Nazi-fascismo, mas, de qualquer forma, ela fora mais propalada no ano anterior.

\footnotetext{
${ }^{228}$ Vavy Pacheco Borges. Getulio Vargas e a Oligarquia Paulista: história de uma esperança e muitos desenganos. São Paulo: Brasiliense, 1979. Da mesma autora, Tenentismo e Revolução Brasileira. São Paulo: Brasiliense, 1992. Ver também Maria Helena Capelato, 1989, op. Cit.

229 Com o intuito de se defenderem das acusações e de colocarem o seu ponto de vista, os paulistas que participaram do movimento armado de 1932 escreveram memórias e ensaios, publicados sobretudo entre 1932 e 1937 (mais de 150), em boa parte trabalhos de uma classe média urbana que se envolveu diretamente na luta. Cf. Vavy Pacheco Borges. Memória Paulista. São Paulo: EDUSP, 1997, pp. 46-48.
} 
Ocorre que 1933 instigou a criação de crônicas antifascistas por parte do escritor. Isto se explica porque o panorama político germânico deste ano foi agitado: sabemos que, em fins de janeiro, o Nazismo agarrava a chancelaria alemã. $E$ algumas semanas depois, com o desencadeamento de um incêndio suspeito no parlamento, o governo impôs um decreto que suspendia os direitos civis constitucionais. Os decretos governamentais passaram a ser executados sem consulta, ignorando a assembléia parlamentar.

Nos primeiros meses da chancelaria de Hitler, os nazistas instituíram um plano de estandardização do país, nomeado Gleichschaltung — a coordenação dos indivíduos e instituições sob as diretrizes nazistas. Uma vasta campanha de propaganda foi executada com o intuito de disseminar os objetivos e ideais do regime. Como conseqüência, os hitleristas passaram a moldar a cultura, a economia e a educação, ou seja, praticamente toda a sociedade alemã.

Belmonte, como veremos adiante, considerava os duros golpes dados pelo Nazismo contra a democracia, a liberdade de expressão e o individualismo, uma aberração absoluta. E, para seu desassossego, o governo brasileiro revolucionário também se apresentava pouco afeito à democracia representativa e à liberdade de expressão, tendo em vista que as eleições para a Assembléia Nacional Constituinte demoraram cerca de dois anos e meio para se concretizarem após Outubro de 1930, e toda a produção cultural se via obrigada a driblar a censura ${ }^{230}$, causando a impressão de que a "maré” política em alguns países estava sendo irresistivelmente atraída para o autoritarismo: especialmente Itália e Alemanha, mas também Portugal e Brasil.

\footnotetext{
${ }^{230}$ A censura, instrumento do governo de Getúlio Vargas desde a Revolução de 1930, foi intensificada a partir de 1935.
} Ver Robert Levine. O Regime de Vargas (os anos críticos, 1934-1938). Rio de Janeiro: Nova Fronteira, 1980 , p. 185. 


\section{O Antifascismo de Belmonte}

O moderno e o novo são, costumeiramente, relacionados pelo cronista com os recentes governos autoritários de sua época, cujo exemplo mais destacado é o Nazi-Fascismo. O escritor paulistano desenvolveu com freqüência, em suas crônicas, apontamentos muito precisos e pertinentes sobre a política do período. Nesse sentido, suas opiniões se aproximam, em alguma medida, das concepções de estudiosos da nossa contemporaneidade especializados nos regimes políticos de Hitler e Mussolini. Segundo o historiador Robert Paxton, o Nazi-Fascismo foi, de fato,

...a novidade política mais importante do século XX: um movimento popular contra a esquerda e contra o individualismo liberal. Ao contemplar o Fascismo, vemos como o século XIX contrastou com o século XX, e o que o século XXI tem que evitar. ${ }^{231}$

Suas características referentes à censura, ao alinhamento de pensamentos e atitudes, ao extremo autoritarismo, ao militarismo e ao imperialismo configuram-se, na visão belmonteana, em uma epidemia que se espalha a passos largos pelo mundo. Inclusive o governo brasileiro, que se mantivera a salvo da inversão propagada por governos “exógenos” até 1930 (cujo exemplo cabal, até então, era a Itália), terminou por sucumbir a ela por meio da permanência do governo de Getúlio Vargas, cujos objetivos colocados em execução o tornavam, segundo Belmonte, progressivamente semelhante aos governos europeus de exceção.

Como podemos compreender o conceito Fascismo, que abrange também o Nazismo ${ }^{232}$ ?

Para Robert Paxton, as sociedades que têm como paradigma o Fascismo, ou um ideário fascista, costumam valorizar a primazia de um grupo coeso (a "Nação") em relação ao qual as pessoas têm deveres superiores a quaisquer direitos, sejam eles individuais ou universais, e existe a subordinação do indivíduo a esse grupo; há a necessidade da autoridade de líderes naturais,

\footnotetext{
231 Cf. Robert Owen Paxton. A Anatomia do Fascismo. São Paulo: Paz e Terra, 2007, p. 46.

${ }^{232}$ Idem, ibidem, pp. 44-47. Cf. também p. 217, onde este autor salienta várias semelhanças entre o Nazismo e o Fascismo da Itália:“Como o regime de Mussolini não conseguiu desenvolver a força alcançada pelo de Hitler, ele muitas vezes é visto como menos que totalitário. No entanto, os mesmos elementos disputavam o poder na Itália fascista e na Alemanha nazista: o líder, o partido, a burocracia estatal e a sociedade civil(...). O resultado final, na Itália, foi o que alguns chamaram de ‘uma versão mais dura da Itália liberal'. Essa visão subestima tanto as inovações introduzidas pelo partido na organização do Estado e na propaganda, em especial em sua relação com a juventude, e a capacidade de Mussolini para atos arbitrários, demonstrada principalmente durante a Guerra da Etiópia, como também o grau de tensão existente entre o Duce, o partido e as elites conservadoras, na versão italiana do Estado dual.”
} 
culminando num chefe nacional que é o único capaz de encarnar o destino do grupo e há a afirmação da superioridade dos instintos desse líder sobre a razão abstrata e universal - o Führer e o Duce não baseiam sua legitimidade nas urnas, mas sim no carisma ${ }^{233}$, uma misteriosa comunicação direta com o Volk ou com a razza, que tende a dispensar ou minimizar a mediação de líderes religiosos e de chefes partidários. Há também o direito do grupo nacional de dominar os demais povos sem limitações de qualquer natureza, sejam elas impostas por leis humanas ou divinas. Esse direito é determinado pelo critério único de uma suposta superioridade do grupo ${ }^{234}$.

O líder queria levar seu povo a um campo mais elevado da política, campo esse que podia ser experimentado de forma sensual: o calor de pertencer a uma raça agora plenamente consciente de sua identidade, destino histórico e poder; o entusiasmo de participar de uma vasta empreitada coletiva; a gratificação de deixar-se submergir numa onda de sentimentos coletivos e de sacrificar as próprias preocupações mesquinhas em favor do interesse grupal; e a emoção do domínio. ${ }^{235}$

O que temos, portanto, é a imagem de uma coletividade de indivíduos de um mesmo Estado, em sua maioria carente de poder (oriunda majoritariamente do proletariado e das classes intermediárias), que se quer harmônica e coesa, que se considera, comumente superior aos outros povos, que se orgulha em obedecer cegamente ao seu líder, e para a qual os direitos ou interesses pessoais jamais devem se sobrepor aos deveres para com o grupo nacional.

Ao usarmos o termo Nazi-fascismo ou fascismos, fazemos referência aos Estados da Alemanha e da Itália. Por outro lado, ao desejarmos nos referir especificamente a um dos dois governos, salientaremos sua nacionalidade logo após o emprego do termo Fascismo, no singular.

\footnotetext{
${ }^{233}$ Segundo Robert Paxton, “Este carisma é semelhante ao 'estrelato' das celebridades da era da mídia, elevado a uma potência mais alta por sua capacidade de ditar a guerra e a morte”. Idem, ibidem, p. 209.

${ }^{234}$ Idem, ibidem, ver pp. 78-79. Sabe-se que a concepção desta suposta superioridade nacional nos fascismos podia ser variável, e determinada unicamente pelos critérios do valor do grupo. No Nazismo, por exemplo, a certeza da superioridade alemã se sustentava em um discurso racista muito mais agressivo e anti-semita do que na Itália de Mussolini. Ver. pp. 273-277.

${ }^{235}$ Idem, ibidem, p. 39.
} 


\subsection{Os Jornais e o Nazi-fascismo}

Fortemente adepta do ideário da paulistanidade e defensora da cafeicultura, a maior preocupação das Folhas era o fato de São Paulo ter sua supremacia política questionada e ameaçada em nível nacional. Talvez por isso, os acontecimentos políticos internacionais e as chamadas “ideologias exóticas” ${ }^{236}$ fossem pouco comentados nos editoriais da Folha da Noite, e até mesmo em suas reportagens. No entanto, este posicionamento reservado da Folha da Noite não coibiu Belmonte de tecer várias e perspicazes críticas, por meio de crônicas e charges, ao Nazi-fascismo, enquanto se manteve mais comedido com relação à esquerda, pois o número de crônicas contra ela foi infinitamente menor e, seu conteúdo, menos ferino. Afinal, os ideários políticos encabeçados por Hitler e Mussolini chegaram a receber do artista os seguintes epítetos: “teratogênico”, “epidemia” e “aberração social” 237.

Ainda que o discurso emanado de nossas fontes principais assuma um viés liberal, ele escapa à tentação de defender idéias apenas conservadoras e por vezes reacionárias, tendência ordinária da maior parte da imprensa paulista liberal e burguesa (e brasileira como um todo) da época. É importante frisar o caráter liberal e, ao mesmo tempo, reacionário de larga parcela da grande imprensa dos anos trinta. Liberal, porque ela era a favor dos pressupostos do Liberalismo, tais como a democracia formal e a defesa da liberdade de comércio, da liberdade de expressão e do individualismo. Reacionário, porque a maior parte de seus membros devotava ódio às esquerdas e habitualmente lhes direcionava críticas virulentas. Reacionário, sobretudo, porque auxiliou a disseminar o pavor pelo Comunismo e, premida entre a escolha pela propriedade (o Estado Novo foi implantado sustentando-se no discurso do combate ao Comunismo) ou pela "liberdade" (a democracia), terminou optando pela primeira. Inimiga declarada das esquerdas, não titubeou em repudiá-las $^{238}$ e em demonstrar respeito - por vezes até simpatia - pelo Nazi-fascismo, regime político símbolo da reação ${ }^{239}$, que buscou reverter todas as conquistas de Direitos Civis alcançadas

\footnotetext{
${ }^{236}$ Aquelas que, por algum motivo, divergiam do Liberalismo.

${ }^{237}$ Cf. Um que virou. Crônica publicada na Folha da Noite (São Paulo) em 26/09/1933, p. 2.

${ }^{238}$ Ver o editorial de O Estado de São Paulo (15/06/1927), in: Maria Helena Capelato e Maria Lígia Prado, op. cit., p. 105: "Somos Conservadores. Entre os regimes coletivistas ou comunistas que abolem a propriedade privada e os outros que a mantêm, não vacilamos, somos pelos outros. Nem a organização social, nem a doutrina política dos comunistas nos seduzem.Os processos de ação que eles têm posto em tática, esses então nos provocam horror...

Dito isto, está dito que não recusaremos a nossa solidariedade aos que lutam contra o comunismo. Te-la-á o governo do Brasil quando o comunismo constituir, na verdade, um perigo para o Estado.”

${ }^{239}$ No século XX, tanto o Fascismo da Itália como o Nazismo constituíram-se em fenômenos reacionários. Ver o verbete “Reação”, elaborado por Giorgio Bianchi (páginas 1073-1074). In: Dicionário de Política, organizado por Norberto Bobbio, Nicola Matteucci e Gianfranco Pasquino. Brasília: Editora Universidade de Brasília, 2000.
} 
após a Revolução Francesa e que almejava banir a emancipação dos judeus, os Direitos do Homem, a democracia e as idéias políticas do Iluminismo do século XVIII ${ }^{240}$.

O ódio ao Comunismo e a tolerância ao Nazi-fascismo foram, certamente, os principais aspectos constitutivos do reacionarismo da imprensa liberal e burguesa de São Paulo, características essas que começaram a se mostrar presentes nos jornais do grupo Folha mais tardiamente, somente a partir de 1935, mas que já eram concepções recorrentes nos seguintes periódicos: n’O Estado de $S$. Paulo, no Diário da Noite, Diário de São Paulo e, com menos intensidade, no A Gazeta.

A singularidade do antifascismo belmonteano reside em sua precocidade e em seu nãoalinhamento às ideologias de esquerda. Precocidade porque, em se tratando de membros da grande imprensa, foi rara a disseminação frequente de idéias antifascistas antes da eclosão da Segunda Guerra Mundial. É claro que, por vezes, esses regimes políticos de exceção estavam na pauta dos editoriais e podiam, eventualmente, ser criticados e renegados. Mesmo assim, a maciça rejeição deles pelo jornalismo liberal só ocorreu alguns anos depois, com o princípio do conflito, e se intensificou quando houve o rompimento do Brasil com o Eixo.

Em um dos raros editoriais da Folha da Noite referente ao Nazi-fascismo ${ }^{241}$, este regime político surge como pouco confiável por causa do desprezo que ele exprimia por alguns "princípios liberais”, tão caros à imprensa burguesa:

O paiz não é propriedade de ninguém e organizal-o, politicamente, não é questão de ideologias, de espírito revolucionário, porem de eleições correctas e verdadeiras (...).As velleidades fascistas de tutela não podem vingar num paiz cujo territorio constitue um obstáculo ao pendor centrallista dos regimes dictatoriaes e o sentimento de cujo povo são também hostis á oppressão de um commando político incompatível com a liberdade de que temos o habito, quando não por educação cívica,ao menos pelo instincto da aventura, da ousadia e dos grandes lances da iniciativa individual de que o paiz é, alias, producto directo.” 242 [grifos nossos]

É certo que a centralização empreendida pelo Governo Provisório causava algum desassossego aos editorialistas da Folha da Noite, pois ela o colocava próximo dos fascismos europeus e de suas pretensões autoritárias, ou “velleidades”. Internamente, os jornalistas discordavam

\footnotetext{
${ }^{240}$ Ver Eric Hobsbawm. Ecos da Marselhesa. Dois séculos revêem a Revolução Francesa. São Paulo: Companhia das Letras, 1996, capítulo 3, páginas 100-101. Ver também Robert Owen Paxton, op. cit., p. 42, 44, 236 e 237.

${ }^{241}$ Referimo-nos aos editoriais compreendidos nos anos que nossa pesquisa abrange, lidos um por um.

${ }^{242}$ Editorial: Em Marcha para a Constituinte. Folha da Noite (São Paulo), 24/01/1933, p. 2. Hemeroteca AE/SP.
} 
da nova concepção de Estado Brasileiro, que, sustentando em parte seu ideário no positivismo de Auguste Comte ${ }^{243}$ e favorecido pela conjuntura política, pretendia enfraquecer o federalismo e glorificar (em detrimento da liberdade individual) as palavras de ordem “coletividade”, “Nação” e "Pátria” como referências absolutas de unidade e harmonia ${ }^{244}$.

Mas ao lermos os editoriais da Folha da Noite, percebemos que o número de críticas referentes ao Nazi-fascismo foi pequeno, muito pouco significativo; e os elogios são igualmente ínfimos. Na verdade, esses regimes de extrema-direita quase não figuravam nos editoriais e, até 1935, o jornal teria uma postura discreta também com relação ao Comunismo, sendo que será apenas depois dos levantes de novembro (chamados pela memória social - especialmente, entre militares - e por grande parte da historiografia de Intentona Comunista) que ele deixaria transparecer com mais ênfase o horror que a esquerda lhe inspirava ${ }^{245}$.

Em contrapartida, no período abordado por esta dissertação, a rejeição ao Comunismo era encontrada com mais veemência nas páginas do maior jornal de circulação no período: $O$ Estado de São Paulo.

Os editorialistas de OESP demonstravam, no início dos anos trinta, pouca apreensão com relação aos Fascismos. E mesmo depois de 1932, com a criação da AIB - Ação Integralista Brasileira -, ele nunca se tornou um tema preocupante. Realmente, o Nazi-Fascismo desfrutava de uma considerável benevolência de OESP, que admirava o soerguimento econômico da Alemanha e, acima de tudo, via nos regimes de força um instrumento eficaz de combate ao Comunismo. Em contrapartida, as esquerdas eram os inimigos irreconciliáveis ${ }^{246}$.

A complacência que o OESP endereçava aos hitleristas e integralistas pode ser explicada pelo fato desses movimentos não terem significado uma ameaça à estabilidade da sociedade burguesa, pois eles defendiam, tanto quanto o liberalismo, “...os mesmos alicerces sobre os quais se funda a estrutura econômico-social do país” ${ }^{247}$. O Nazi-Fascismo passou a ser criticado pelos editorialistas do jornal OESP apenas no final da Segunda Guerra Mundial, quando a situação militar dos países envolvidos no conflito já era visível. Nesse período, o jornal se encontrava sob a intervenção do Estado Novo, e este apoiava os Aliados contra o Eixo desde 1942.

\footnotetext{
${ }^{243}$ Ver Robert Levine. Pai dos Pobres? O Brasil e a Era Vargas. São Paulo: Companhia das Letras, 2001, p. 16-19 e p. 36-37.

${ }^{244}$ Ver Marilena Chaú. Conformismo e Resistência: aspectos da cultura popular no Brasil. São Paulo, Brasiliense, 1989, p. 102-108.

${ }^{245}$ Cf. Maria Helena Capelato. Os Arautos do Liberalismo. Imprensa Paulista (1920-1945). São Paulo: Brasiliense, 1989, p. 122.

${ }^{246}$ Ver Maria Helena Capelato e Maria Lígia Prado, op. cit., p. 102-104.

${ }^{247}$ Idem, p. 104.
} 
O Diário da Noite e o Diário de São Paulo, ambos pertencentes à empresa jornalística Diários Associados, de Assis Chateaubriand, também manifestavam um anticomunismo evidente, ao passo que o Nazi-fascismo era muito pouco criticado em seus editoriais ${ }^{248}$. Assim, os Diários adotaram um discurso violento com relação ao Comunismo e, ao mesmo tempo, poupavam os governos de Mussolini e Hitler. Este também foi o panorama encontrado no jornal A Gazeta, ainda que a freqüência e a intensidade de seu anticomunismo não tenham sido tão incisivas como no OESP e nos Diários $^{249}$.

Na mesma época, uma postura de relativa simpatia pelos fascismos e de firme recusa ao Comunismo foi igualmente freqüente na imprensa liberal dos Estados Unidos e da Grã-Bretanha. Evidentemente, depois que esses países entraram em guerra contra a Alemanha, a tolerância prófascismo desapareceu das páginas de seus periódicos.

${ }^{248}$ Cf. Maria Helena Capelato, 1989, pp. 121-122.

${ }^{249}$ Idem, ibidem. 


\subsection{Nas Linhas e Entrelinhas das Crônicas}

Se os editoriais da Folha da Noite praticamente se ausentavam de se posicionar frente à extrema-direita, totalmente outra era a opinião política impressa em nossas fontes. Desde a primeira metade dos anos trinta, Belmonte procurou desacreditar o ideário nazi-fascista. Vejamos a crônica Aryanos e Semitas:

O que, neste momento, está convulsionando de forma tão impetuosa, a complicada terra de Goethe, é a questão racial. E essa questão assume, agora, o seu aspecto mais impressionante, com a declaração feita pelo chefe do Partido Nacional-Socialista, da Silésia, de que todos os membros do Partido que não forem casados com mulheres aryanas, devem demittir-se imediatamente(...). Não se sabe ainda de que forma o hitlerismo conseguirá estabelecer, com rigorismo scientifico, a pureza_racial desta ou daquela senhora, principalmente quando se exige que essa senhora seja aryana (...). Aos nacional-socialistas não tem tanta importância a cor da pelle e dos olhos como, principalmente, a forma do nariz. Quem quizer encontrar os aryanos mais puros terá que ir á Pérsia e á Índia,onde não existem louros, mas onde, também não existem narizes de tucano (...). O que, porem, está assentado, como cousa certa, é que os aryanos provém da Índia. E quanto á sua ramificação na Europa, isso é matéria controvertida, na qual não se encontram dois sábios com opiniões eguaes, sabendo-se apenas em ultima analyse que são aryanos os celtas, os latinos, os hellenos, os albanezes, os germanos e os slavos.

Todavia, como os racistas exigem que os seus adeptos só se casem com aryanas, elles podem unir-se ás escuríssimas hindús, ou ás moreníssimas afghans, que são mais aryanas do que o próprio Hitler.

Concordarão os racistas com esse cruzamento complicado? Estou certo que não. ${ }^{250}$ [grifos nossos]

O discurso racista surge, nas linhas dessa crônica, sustentado por idéias que carecem de lógica, irracionais, permeadas por absurdos. A argumentação da superioridade racial dos arianos é questionada e desconstruída para o leitor da Folha.

${ }^{250}$ Crônica Aryanos e Semitas. Folha da Noite (São Paulo), 31/08/1933, p. 2. Hemeroteca AE/SP. 
Conforme consta na crônica, os estudos sobre a disseminação do "povo ariano" na Europa parecem muito pouco sérios sob o parâmetro científico. Suas conclusões são tão desencontradas (“...os aryanos provêm da Índia. E quanto à sua ramificação na Europa, isso é matéria controvertida, na qual não se encontram dois sábios com opiniões eguaes...”) que praticamente todos os europeus poderiam ser "arianos” (para horror dos nazistas): os celtas, os latinos, os germânicos, os gregos, os albaneses e até mesmo os eslavos! Se todos europeus podem ser arianos, a igualdade racial impera no continente, e, portanto, a idéia de uma "raça" ou nação supostamente superior encontra-se absolutamente equivocada.

E o cronista prossegue indagando, nas entrelinhas, se seria digna de crédito e estaria correta uma política que discrimina as pessoas por meio de suas características faciais ("Não se sabe ainda de que forma o hitlerismo conseguirá estabelecer, com rigorismo scientifico, a pureza_racial desta ou daquela senhora, principalmente quando se exige que essa senhora seja aryana (...). Aos nacionalsocialistas não tem tanta importância a cor da pelle e dos olhos como, principalmente, a forma do nariz.”). E se os líderes alemães acreditam entusiasticamente no "mito ariano”, que indica a origem de seu povo no Oriente - Pérsia e Índia -, porque eles exigem tanto rigor eugênico à hora de celebrar o matrimônio? Se o "mito ariano” tem realmente alguma lógica, que mal haveria em Hitler e outros chefes nazistas liberarem o casamento dos alemães com as “escuríssimas” indianas ou com as “moreníssimas” afegãs, cuja cor da pele é o inverso da brancura epidérmica desejada pelo regime? Afinal, as mulheres orientais “...não são mais arianas do que o próprio Hitler”, já que a terra natal delas foi o "criadouro" da raça superior?

Se o partido da suástica rejeita essa suposta união matrimonial sustentada na própria teoria do “mito ariano”, tão cara a ele, pode-se concluir que o nazismo e seus pressupostos não são nada além de deturpações científicas e mentiras e que, por isso, não devem conquistar a mínima simpatia ou credibilidade dos leitores. Ademais, Belmonte deixa explícito o profundo autoritarismo desse governo que determina, de modo impositivo, a "raça” que detém características consideradas “impuras” e “degeneradas”,251.

Percebe-se um certo deboche por parte do cronista quando ele se refere aos judeus como "os narizes de tucano". Ainda que suas linhas criticassem o racismo, ele não deixou de fazer uso do estereótipo físico do judeu para provocar o riso. De qualquer modo, o estereótipo empregado por

251 Ver Luiz Nazário, “O Expressionismo e o Nazismo”, in: Guinsburg, J. (org.). O Expressionismo. São Paulo: Perspectiva, 2002, p. 649-677 passim, e "O Expressionismo e os meios de Comunicação”, in: op. cit., p. 575-605 passim. 
Belmonte constitui um recurso cômico, não objetivando, em absoluto, disseminar o ódio racial propugnado pelos Nazistas ${ }^{252}$.

Algumas crônicas cuja temática girava em torno dos fascismos pareciam antever ou perceber muito precocemente certas ambições desses regimes políticos. Elas só foram reveladas ao mundo mais detalhadamente no fim da guerra, e corporificavam-se na pretensão de domínio irrestrito sobre a sociedade, no sentido de estabelecer, por meio de propaganda política maciça - atuante em todas as instituições de trabalho, estudo e lazer -, o pensamento e o comportamento considerados corretos ${ }^{253} \mathrm{e}$ na instituição do Terror, da estrutura organizacional repressiva como instrumento de controle total da sociedade $^{254}$. A propaganda política, por sua vez, sustentava-se sistematicamente na mentira.

Diretrizes de governos autoritários estão presentes na crônica “Gleichschaltung”. A tentativa de estandardização do pensamento empreendida pela nazificação da Alemanha foi uma delas:

Gleichschaltung é um neologismo criado pelos hitleristas, sem equivalente em nenhuma outra língua, para indicar o movimento histórico do nacional-socialismo no sentido de estandardizar a mentalidade allemã na ideologia racista. Ou, como explica o Sr. Goebbels, ministro da propaganda, “...é a transformação nacional-socialista do Estado, do partido e de todas as associações, o desenho dos primeiros contornos de uma situação que será, um dia, a situação normal da Allemanha quando não houver mais que uma opinião, um só partido e uma conviç̧ão."

Embora a Allemanha se encontre na Europa, hoje, em situação dramática, arrazada materialmente pelo Tratado de Versalhes - o que, até certo ponto, justifica esse movimento de união interna para a defesa interna para a defesa comum contra os perigos que a cercam de todos os lados - ainda assim, parece difícil que o nacionalsocialismo consiga esse objectivo temerário antes de duas ou três gerações. Mesmo assim, já a Allemanha poderá vangloriar-se de ter realizado uma áfrica, porque nós, nestas terras morenas onde a jandaia canta nas copas da carnahuba, ainda teremos que passar uma vidinha bem apertada durante quatro gerações.

\footnotetext{
${ }^{252}$ A postura anti-racista de Belmonte desdobra questões tematizadas pelos modernistas (Macunaíma nasce negro e vira branco) e é contemporânea da ênfase cultural nas obras de Gilberto Freyre.

Ver Ricardo Sequeira Bechelli, Metamorfoses na interpretação do Brasil - Tensões no paradigma racista. São Paulo: FFLCH-USP, 2009. (Tese de Doutorado). Ver também Mário de Andrade. Macunaíma (O herói sem nenhum caráter).

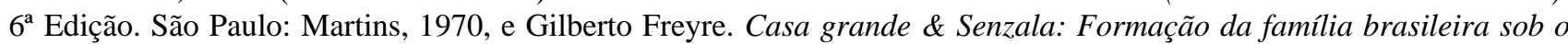
regime de economia patriarcal. $9^{a}$ Edição. Rio de Janeiro: José Olympio, 1958.

${ }^{253}$ Ver em Hannah Arendt o capítulo III, “Totalitarismo”, em especial as páginas 372-381. In: Origens do Totalitarismo. São Paulo: Companhia das Letras, 1989.

${ }^{254}$ Hannah Arendt, op. cit., p. 470-485 passim.
} 
Todavia, como quatro gerações são gerações de mais, e como o povo brasileiro não terá paciência de esperar tanto tempo para sahir do buraco em que o meteram os salvadores da pátria, pensa-se em instituir por estas bandas um governo forte, afim de que não haja um suicídio collectivo de quarenta milhões de encalacrados. E, para que não haja queixas e reclamações por parte dos afflictos, a força desse governo que nos promettem consistirá em realizar a 'gleichschaltung' cabocla, de jeito que todos os quarenta milhões de encalacrados pensem que não são encalacrados ou, se o pensarem, que não digam nada.

Á primeira vista, parece impossível a realização de tão impressionante empreitada. Mas, bem analysadas as condições em que ela se fará, ver-se-á que não há nada tão simples. Tudo dependerá da força desse governo.

É evidente que não me refiro á sua força material ou mesmo política. O de que se faz mister neste angustioso transe, não é um homem que possua, ao alcance de uma ordem, todas as forças de terra e mar. Nem mesmo um homem que tenha ao seu dispor todas as forças políticas do paiz. O de que precisa, para a estandardização da opinião e da convicção brasileiras, é de um homem que possua forças ocultas - um hypnotizador, por exemplo. Ora, homens desse gênero não nos faltam. Que se invista, pois, um desses magos, de poderes discricionários, para que elle,lançando do Cattete, sobre o vasto território brasileiro, os seus fluídos magnéticos, exclame a todos nós:

- Brasileiros! Nunca vereis país nenhum como este! Olhae que céo, que mar, que rios, que floresta! As quatro gerações foram uma blague do Juarez! Os 'deficits' allucinantes são intrigas da opposição! O desbarato de doze milhões de contos é pilheria do Cincinato! O negócio da Banha é calumnia do Hermes Cossio! O paiz nada em ouro! O commercio navega em ouro! A industria dorme sobre o ouro! O povo come ouro! A Inglaterra deve-nos alguns milhões de esterlinos mas vae pagarnos! A Norte América deve-nos vários milhões de dóllares e já nos está pagando...! E assim por diante. Sob a acção hypnotica do dictador, todos nós exclamaríamos em coro:

- Perdoemos as dívidas estrangeiras! Já temos ouro de mais! Não queremos mais nada. E dessa fórma, com um só pensamento, uma só convicção e um só ideal, o Brasil seria o El-Dorado do mundo.

Salvo disposições em contrário - porque os nossos credores são diffíceis [sic] de hypnotizar...”255 [grifos nossos]

${ }^{255}$ Belmonte, “Gleichschaltung”. In: op. cit, p. 35-36. Publicada na Folha da Noite (São Paulo) em 30/04/1934, p. 2. 
Percebe-se, nos três primeiros parágrafos transcritos, que o cronista não compartilha do entusiasmo transmitido pelo ministro da propaganda alemão. Belmonte usa o adjetivo "temerário" para desvalorizar o objetivo nazista de estandardização da sociedade. O desconforto implícito na questão proposta pelas entrelinhas belmonteanas refere-se a conjecturas sobre os meios que seriam empregados para a padronização de toda uma nação. A resposta a essa indagação é sugerida quando o autor faz uma comparação entre as medidas políticas da Alemanha de Hitler e do Brasil de Getúlio Vargas, e conduz o leitor à suposição de que a estandardização de uma coletividade nacional inteira se torna uma hipótese muito pouco provável se os aparelhos de repressão do Estado não forem empregados:

Gleichschaltung (...) “...é a transformação nacional-socialista do Estado, do partido e de todas as associações, o desenho dos primeiros contornos de uma situação que será, um dia, a situação normal da Allemanha quando não houver mais que uma opinião, um só partido e uma conviç̧ão.” (1º parágrafo)

E, para que não haja queixas e reclamações por parte dos afflictos, a força desse governo que nos promettem consistirá em realizar a 'gleichschaltung' cabocla, de jeito que todos os quarenta milhões de encalacrados pensem que não são encalacrados ou, se o pensarem, que não digam nada. ( $3^{\circ}$ parágrafo)

Ao mesmo tempo em que Belmonte compara os dois governos e aponta sua predisposição autoritária, ele salienta as suas peculiaridades. Ainda que extremamente autoritário e racista, o governo germânico conseguiu empreender mudanças significativas no país (realizou “uma áfrica”), apesar de o cronista não esclarecer quais foram elas. Mas o seu congênere brasileiro, por sua vez, além de ser marcadamente antidemocrático, afundara ainda mais o povo brasileiro (leia-se: o homem comum) na crise econômica. A situação brasileira descrita no terceiro parágrafo é tão alarmante, e a predisposição do Governo Provisório para mudá-la é tão ínfima - conforme os casos de corrupção e de desgoverno forçadamente negados no discurso do sexto parágrafo - que ele só poderia se sustentar no poder com o prosseguimento do "uso da força” - ou seja, do aparato de repressão - e com a incessante repetição de mentiras por um ditador-hipnotizador, que coloque como críveis sugestões absurdas. No entanto, isso não significa que Belmonte considere o Brasil de Vargas pior do que a Alemanha nazista. Sugerimos que o cronista usa da comparação entre ambos para aproveitar-se de 
um recurso retórico, uma vez que o Brasil é a sua referência, local aonde ele vive, escreve e desenha. Ou seja, o artista utiliza-se desta comparação para melhor poder zombar do governo brasileiro, das suas graves incompetências - segundo a concepção de Belmonte.

O Governo Provisório necessita, portanto, de um hipnotizador, de um farsante profissional que, “lançando seus fluídos magnéticos do Catete”, consiga ocultar a degradante realidade brasileira. Ao apontar a farsa como característica inerente ao Governo Provisório, Belmonte salienta o seu aspecto bufo. A palavra bufonaria significa algo não sério ${ }^{256}$, desmerecedor de credibilidade.

É necessário atentar para o efeito bufo, que vem acompanhado das idéias de inversão e subversão ${ }^{257}$. Nesse sentido, o governo brasileiro presente na crônica “Gleichschaltung” posicionase no pólo oposto àquilo que se espera de uma administração pública racional e bem-intencionada: em lugar da honestidade financeira, a corrupção e a incompetência em assuntos econômicos; em lugar de planejar e executar medidas que tornem a situação político-econômica brasileira menos aflitiva, o governo dissemina a mentira, a farsa e o engodo.

Almejando representar o Governo Provisório justamente pelo contrário daquilo que seria esperado de uma boa administração pública, Belmonte terminou por despi-lo de toda respeitabilidade. E a ironia empregada na crônica se presta para reafirmar as inversões realizadas, novamente desabonando-o. O hipnotizador, por exemplo, afirma que “o país nada em ouro” e que “o povo [brasileiro] come ouro”. Mas o contexto informa ao leitor que o que se passa no país é o oposto: sem crédito e falido, ele está à beira da bancarrota.

Eis, portanto, os aspectos do Nazismo que o escritor evidencia em suas crônicas: o antiliberalismo, o racismo, o profundo autoritarismo, o engodo e a mentira. E o Governo Provisório também apresenta essas características - ainda que, na maioria das crônicas, elas apareçam com menos intensidade do que no Nazismo e haja a ausência do racismo no governo de Getúlio Vargas.

As comparações que Belmonte por vezes faz entre o Nazismo e o governo brasileiro tem como objetivo tirar-lhes a credibilidade, ridicularizá-los e desvalorizá-los.

Como jornalista, chargista e cronista bem informado da situação política dos países europeus, Belmonte chama atenção para o Gleichschaltung: a coordenação, ou o nivelamento do povo alemão sob um único modelo, o nazista ${ }^{258}$. Progressivamente, após 1933, a ideologia nacional-socialista foi controlando as pessoas, instituições e organizações alemãs.

\footnotetext{
${ }^{256}$ Mikhail Bakhtin, op. cit., p. 65.

${ }^{257}$ Ibidem, p. 337.

${ }^{258}$ Cf. Robert Owen Paxton, op. Cit., p. 204.
} 
No entanto, como historiadores do séc. XXI, precisamos ter cuidado para não resvalarmos em uma interpretação excessivamente simplificada deste processo de nivelamento; ele não foi absolutamente inevitável e nem linear, e envolveu muito da força estatal, mas também a negociação. Certas organizações sociais solidamente estabelecidas não foram tão fácil e rapidamente controladas pelo regime nazista. Na maior parte dos casos, elas procuraram defender alguma autonomia (ainda que de maneira discreta), como as paróquias católicas e com os grupos estudantis universitários denominados Fraternidades ${ }^{259}$.

Belmonte conduz suas crônicas de sorte que não falte ao Nazi-fascismo a balda de paradigma autoritário. Nos anos 30, por exemplo, quando o embate entre feministas e conservadores sobre a condição feminina era constante e intenso, o Nazismo, ideário político europeu de extrema-direita, se posicionava pleno de certeza no debate - era contra os direitos civis e políticos das mulheres. Mas este posicionamento inabalável provinha muito mais da inexistência de discussões no interior da sociedade nazista do que de uma concepção adotada após a análise sustentada em argumentações diversificadas. Ou seja, o cronista dissipava por completo no leitor quaisquer dúvidas de que o Nazifascismo era um conjunto de idéias que se queria incontestável:

Não sei se o meu heróico e abnegado leitor tem opinião formada a respeito do feminismo. Eu não tenho. Acho que ter opinião sobre esse caso complicado, é um acto de legitimo heroísmo, numa época em que as próprias mulheres não a tem. Mas o nacional-socialismo allemão sabe o que quer. E tem a 'coragem de affirmar' que o feminismo não passa de uma 'blague' moderna que deve ser banida da vida prática para o bem dos homens e felicidade geral das mulheres.

Enquanto os feministas asseguram que o papel da mulher é intervir na vida pública, hombro a hombro com o homem, gosando os mesmos direitos e exercendo os mesmos deveres - e enquanto os anti-feministas affirmam que o lugar da mulher é no lar, cozinhando para o marido e cuidando da prole - o nacional-socialismo tem uma concepção inedita do problema.”260 [grifos nossos]

\footnotetext{
259 “As fraternidades das universidades alemãs são um bom exemplo de sobrevivência. O nazismo era tão atraente aos estudantes que, mesmo antes de 1933, sua organização nacional havia sido dominada por ativistas do partido. Esperar-seia, portanto, que, após janeiro de 1933, as fraternidades houvessem desaparecido sem protestos no Gleichschaltung. Apesar das tentativas do regime de transformar os clubes de duelo "reacionários" em Kameradschaften (centros sociais e de treinamento) do partido, as fraternidades continuaram existindo em caráter não-oficial, em parte porque poderosos oficiais nazistas pertencentes às associações da 'velha guarda' ou de ex-alunos as defendiam, e em parte porque os alunos tornaram-se cada vez mais apáticos à propaganda do partido”. In: Idem, ibidem.

${ }^{260}$ Belmonte. A Mulher e os Filhos. Crônica publicada na Folha da Noite (São Paulo) em 19/09/1933, p. 2.
} 
Para o Nazi-fascismo, o feminismo e a defesa dos direitos das mulheres são inadequados às aspirações de meninas, senhoritas e senhoras e à “felicidade geral das mulheres”, cuja igualdade perante os homens se configuraria numa inversão total e bizarra da ordem natural e biológica. Portanto, ao contrário daquilo que propugnavam os feministas, a mulher nazista deve se restringir aos limites do lar, num espaço marcadamente privado.

Pelas palavras empregadas, o autor procura guiar a percepção do leitor no sentido de lhe ser evidente o viés autoritário do regime político da suástica ${ }^{261}$. Neste, não há sugestão de idéia(s), mas sim imposição. Suas concepções passam a ser dogmas, surgindo, assim, com um contorno de infalibilidade e indiscutibilidade: “O 'Voelkischer Beobachter', jornal racista de Munich, escreveu, ha pouco tempo, um artigo subordinado a este titulo, que é um verdadeiro dogma sociológico: 'O papel da mulher: nutrir bem o guerreiro allemão'."262 [grifos nossos]

No Nazi-fascismo, a concepção de mulher submissa aos “machos” - ao líder nacional e ao esposo - prevalece. Seu lugar de ação é o espaço do lar, sua incumbência, os cuidados serviçais direcionados ao homem e aos seus filhos, mas não exatamente do modo que os conservadores ${ }^{263}$ propugnavam, o da constituição de família como um fim em si. A mulher alemã tem seu projeto de vida redirecionado no Nazismo; a organização doméstica e o bem-estar de sua família não devem ser mais os únicos objetivos. Sua principal função nesta nova sociedade está voltada para contribuir com a preparação de uma futura guerra, e trata-se primordialmente de “...nutrir bem o guerreiro alemão”.

Vejamos mais uma passagem da crônica $A$ mulher $e$ os filhos, publicada em dezenove de setembro de 1933:

Como se vê, o caso ahi, assume uma feição inédita e desnorteante. Constituía praxe inveterada, até ha pouco tempo, dizer-se que a mulher deve cuidar do marido e dos filhos. Mas isso era, evidentemente, um anachronismo incommodo. Marido e filhos são coisas que existiram em outros tempos, quando o mundo ainda era aquella choldra rotineira de vinte annos atrás. Hoje, com o progresso e, principalmente, com o surto civilizador do mundo occidental, aquellas entidades lyricas desappareceram para dar lugar a estas realidades praticas: os guerreiros. Marido e filhos são productos de um

\footnotetext{
${ }^{261}$ O Nazi-fascismo não tolerava modos de vida ou idéias díspares daquelas propugnadas por ele. Nesse sentido, qualquer pessoa que se distanciasse delas se tornava um inimigo passível de condenação: "Na paisagem mental fascista, os inimigos internos aumentavam prolificamente em número e em variedade, à medida que o ideal de um Estado nacional homogêneo tornava mais suspeitas as diferenças.” Ver Robert Owen Paxton, op. Cit., p. 71.

${ }^{262}$ Belmonte. A Mulher e os Filhos. Crônica publicada na Folha da Noite (São Paulo) em 19/09/1933, p. 2.

${ }^{263} \mathrm{O}$ que seria ter uma visão conservadora com relação ao comportamento feminino nas primeiras décadas do século $\mathrm{XX}$ ? Refere-se a restringir as aspirações da mulher aos limites domésticos, “...até encaixá-la no papel de 'rainha do lar', sustentada pelo tripé esposa - mãe - dona de casa." In: Maria Maluf; Maria Lucia Mott. "Recônditos do Mundo Feminino.” In: Nicolau Sevcenko (org.). História da Vida Privada no Brasil - República: da Belle Époque à Era do Rádio - volume III. São Paulo : Companhia das Letras, 1998, p. 373.
} 
cyclo histórico apodrecido e desappareceram com o fallecimento da supremacia burgueza; são, apenas sentimentalismos atrapalhantes que a éra moderna já não supporta."264 [grifos nossos]

Percebe-se que o artista considera seu tempo como o da mudança par excellence, absolutamente instável e fugidio, pois, a concepção de mundo que se tinha há vinte anos tornou-se obsoleta para o presente. O marco das transformações mais rápidas e radicais está posicionado nos primórdios da $1^{\mathrm{a}}$ Guerra Mundial, quando o modo de se fazer a guerra e de senti-la foi revolucionado e, logo após dela, vieram o caos econômico, a crise da política liberal e a escalada de regimes políticos inovadoramente autoritários, cujo exemplo cabal é o Nazismo da Alemanha. O escritor aponta também para duas visões distintas e completamente opostas de modernidade: a dos meninos e homens guerreiros nazi-fascistas e a dos feministas, considerada pelos hitleristas uma "blague moderna”.

Nota-se que as palavras referentes aos aspectos nazificantes da sociedade alemã ou à escalada ao poder de outros “regimes fortes” em diversos países são parecidas com aquelas usadas pelos políticos brasileiros vitoriosos em 1930, sugerindo, nas entrelinhas, possíveis semelhanças entre a política alemã e a brasileira. Tanto o Nazismo como o Varguismo se afirmavam, ao nível do discurso, como o novo e o progresso, como um ciclo revolucionário, refletindo a idéia de potência e de vida, ao passo que os regimes anteriores a eles eram anacrônicos, apodrecidos e carcomidos, ligados à idéia de corrompimento, fraqueza e morte. Os adjetivos empregados na crônica são particularmente marcantes: é o novo e o moderno em contraste com o velho, com o "fallecimento". No entanto, concomitante ao emprego deles, o artista se empenha em desqualificar essas inovações políticofamiliares, colocando-as como desumanas e irracionais. Ainda que o regime político brasileiro não tivesse sido mencionado em sua crônica, o leitor atento e bem-informado perceberia a aproximação indireta feita pelas linhas de Belmonte.

Ao expor suas idéias e discorrer sobre o Nazi-fascismo, o escritor destaca o aspecto desumanizador deste, direcionado para a padronização e a coisificação dos seres humanos. Nas crônicas, as pessoas conduzidas por esse regime político ganham contornos de meros instrumentos úteis que facilitam o alcance de seus objetivos de domínio e de controle expansionistas. Eis as linhas da segunda coluna:

Ora, o nacional-socialismo, transformando essas figuras domésticas em guerreiros e impondo à mulher o dever de bem alimental-os, coloca o sexo frágil numa situação de

${ }^{264}$ Idem, ibidem. 
indisfarçável atrapalhação, principalmente quando affirma, pela voz do diário de Munich que "é sobretudo a nossa mocidade hitlerista que precisa ser bem alimentada...”(...). Ora, quem conhece a situação econômica do povo allemão, e sabe que elle se encontra enrascado na mais dramática penúria, dará inuteis tratos á bola para descobrir de que fórma essas pobres mulheres conseguirão meios para 'bem alimentar o guerreiro allemão’.

É verdade que a certa altura, o jornalista exclama: 'Sem duvida, é muito difficil, para innumeras mulheres allemãs, satisfazer, nesta época particularmente dura, a essas exigências todas’. Mas é verdade tambem que, logo adiante, elle acrescenta que, mesmo assim, todo o sacrifício é pouco, pois ellas, com o seu trabalho, tudo conseguirão em benefício da pátria. ${ }^{265}$ [grifos nossos]

As relações afetivas e familiares são quase que desconsideradas nesses regimes de extremadireita; há apenas deveres, tarefas e “papéis” absolutamente inquestionáveis para os elementos da sociedade - distribuídos conforme a idade e o sexo de cada um. A simples suposição de que parte das pessoas poderia formar família em busca de satisfação, conforto amoroso e emocional ou por outra motivação parece irrelevante para o Nazi-fascismo. Cada membro da comunidade nacional deve perseguir os objetivos do Führer, e tornar-se mais uma das peças das imensas engrenagens que levarão o volk na direção de guerras imperialistas.

Assim, as mulheres assemelham-se a “máquinas” de procriar e alimentar. Os homens e jovens, como soldados, fazem as vezes de “equipamento” de ataque, invasão e destruição. Tudo está já pré-determinado, e basta aos autômatos cumprir, passo-a-passo, aquilo que foi determinado pelo Regime Nazista. A homogeneização e a coisificação apresentadas por Belmonte são tão incômodas, que não resta nenhum traço de individualidade nos alemães da dita crônica. Pelo contrário, o artista afirma que “...aquellas entidades lyricas desappareceram para dar lugar a estas realidades praticas: os guerreiros. Marido e filhos são productos de um cyclo histórico apodrecido e desappareceram com o fallecimento da supremacia burgueza; são, apenas sentimentalismos atrapalhantes que a éra moderna já não supporta.” [grifos nossos]

“Entidades líricas”, “sentimentalismos”: palavras referentes à arte e à sensibilidade individual, para o Nazismo, atrapalham e se ligam a um ciclo histórico decrépito que a nova era - a modernidade - não permite mais. Nos novos tempos, tudo deve ser minimamente planejado e previsto, e rigidamente seguido e executado.

${ }^{265}$ Idem, ibidem. 
O rígido direcionamento comportamental dos alemães é marcante na crônica. As mulheres são apenas as mães de futuros guerreiros, e elas se deparam com a imposição de um dever supremo: alimentá-los bem. Os jovens devem almejar, sobretudo, a guerra. Qualquer outro objetivo deve figurar como secundário. É assim que o Führer quer, logo, é assim que deve ser.

Percebe-se que Belmonte apresenta o regime da suástica como inimigo irredutível da individualidade e da ação política autônoma da coletividade. Afinal, o governo esperava dos alemães lealdade, obediência e eficiência, acima de tudo. Neste sentido, as crônicas do artista paulistano nos fazem pensar, como antecipação artística, em algumas passagens do livro A Condição Humana, de Hannah Arendt (1958), quando a autora afirma que no mundo contemporâneo, há a ameaça constante de a imprevisibilidade da ação e da participação no espaço público (na política) ser cerceada e preterida pelo utilitarismo na mesma ${ }^{266}$, cujo modelo seria o processo de fabricação, tal como o trabalho organizativo, prático e impessoal do administrador de uma grande indústria, que prima pela máxima eficiência na fabricação. Portanto, quando rigidamente pautada por metas, eficiência e resultados pré-determinados, a política tende a excluir o diálogo e a participação popular efetiva, revelando-se, assim, pouco democrática, autoritária ou até mesmo totalitária ${ }^{267}$.

Como representante caro ao mundo moderno, o liberalismo (seu ideário) valorizava a individualidade, a autonomia, a reflexão e a ação democrática e consciente dos homens no espaço público. O Nazi-fascismo, por sua vez, “filho não-reconhecido” dessa mesma modernidade porque “cria” de seus desvios ${ }^{268}$, propugnava o oposto: a supressão da ação, da autonomia e a padronização e instrumentalização de tudo aquilo que se refere ao humano. Estes aspectos seriam levados ao seu paroxismo durante os anos finais da Segunda Guerra Mundial, quando tanto os prisioneiros dos

\footnotetext{
266 "Somente na era moderna a convição de que o homem só conhece aquilo que ele mesmo faz, de que suas capacidades supostamente superiores dependem da fabricação e de que ele é, portanto, basicamente um homo faber e não um animal rationale, trouxe à baila as implicações muito mais antigas da violência em que se baseiam todas as interpretações da esfera dos negócios humanos como a esfera da fabricação".

"Toda a terminologia da teoria e do pensamento político atesta claramente o quanto foi persistente e bem sucedida a transformação da ação em modalidade da fabricação, e torna quase impossível discutir esses assuntos sem que se empregue a categoria de meios e fins e se raciocine em termos de 'instrumentalidade' (...). Enquanto acreditarmos que, na esfera política, lidamos com meios e fins, não poderemos impedir que alguém recorra a todos os meios para alcançar fins premeditados”. Cf. Hannah Arendt. A Condição Humana. 10ª ed. Rio de Janeiro: Forense Universitária, 2007, pp. 240-241.

${ }^{267}$ A quase ausência do uso do conceito totalitarismo nas linhas dessa dissertação foi proposital. Seria anacrônico imaginar seu emprego pela imprensa brasileira nos anos de 1932-1935. Para os indivíduos politizados da época, o Nazismo e o Fascismo italiano surgiam como governos cujo "autoritarismo" parecia novo, singular porque exacerbado, mas ainda não era qualificado como totalitário.

${ }^{268}$ Após as repercussões negativas que tiveram as sangrentas batalhas da Primeira Grande Guerra e o desencadeamento das conseqüências da crise econômica mundial, em fins da década de vinte, o Nazi-fascismo encontrou um terreno fértil para se desenvolver por causa das promessas não-realizadas do liberal-capitalismo, tal como oferecer conforto e bemestar para a maior parte das pessoas.

No entanto, devemos lembrar que movimentos fascistas surgiram em quase todos os países da Europa, mas regimes fascistas em apenas dois deles (Itália e Alemanha), que, por condições que lhes eram específicas, favoreceram a ascensão dos fascismos. Espanha e Portugal, na época, possuíam muitos traços em comum com o Fascismo, embora muito associados a argumentos católicos. Áustria, Hungria, Grécia, Polônia e Romênia tiveram governos de inspiração fascista.
} 
campos de concentração, assim como os soldados e civis alemães - e cada um desses grupos sofreu esse processo de modo específico -, foram destituídos de sua humanidade e reduzidos à categoria de coisa $^{269}$, de instrumento.

Belmonte sugere que as sociedades que se curvam aos "regimes fortes", como o Nazifascismo ou outras ditaduras, indubitavelmente traem o conjunto de idéias do liberalismo europeu, o que se configura, para o autor, em um grande retrocesso histórico. Logo, a ironia contida nesta frase que se segue, é evidente: “...Hoje, com o progresso e, principalmente, com o surto civilizador do mundo occidental, aquellas entidades lyricas desappareceram para dar lugar a estas realidades praticas: os guerreiros." 270

Pode haver algum progresso ou "surto civilizador" para grupos humanos tão cegamente conduzidos por um poder arbitrário e com tendências belicosas, como se o líder deste fosse uma espécie de rei "tribal” ou - principalmente - um xamã, ainda mais depois das experiências democrático-liberais da contemporaneidade de então? Ao refletirmos sobre este aspecto da crítica de Belmonte voltada ao Nazi-fascismo - o retrocesso da organização política e social (se se tiver como paradigma a Ilustração e o liberalismo europeus) -, é oportuno lembrarmos das interessantes ponderações de Luiz Nazário sobre as sociedades primevas e as totalitárias do recente século XX:

Nas sociedades tribais, a manipulação do coletivo paranóico era a ocupação dos feiticeiros: os xamãs alimentavam-se do terror metafísico que dominava a tribo, irresistivelmente atraída por seu 'carisma', e apresentavam curas mágicas para a incurável angústia da contigência (...). O ditador totalitário é o xamã do século XX, oferecendo o maniqueísmo às massas, como panacéia de suas frustrações, para que elas possam perseguir grupos minoritários sem defesa, acusados de engendrar planos diabólicos. Assim, ao projetar toda a carga destrutiva do coletivo paranóico sobre os judeus, Hitler não ascendeu ao poder como um político comum, mas como o profeta de uma religião monstruosa, assimilando a milenar tradição anti-semita do Ocidente para radicalizá-la numa até então inconcebível utopia de destruição, tornada factível com o concurso dos modernos meios de comunicação de massa. ${ }^{271}$

\footnotetext{
${ }^{269}$ Para Hannah Arendt, especialmente no caso dos prisioneiros, “Os campos [de concentração] destinam-se não apenas a exterminar pessoas e degradar seres humanos, mas também servem à chocante experiência da eliminação, em condições cientificamente controladas, da própria espontaneidade como expressão da conduta humana, e da transformação da personalidade humana numa simples coisa, em algo que nem mesmo os animais são; pois o cão de Pavlov que, como sabemos, era treinado para comer quando tocava um sino, mesmo que não tivesse fome, era um animal degenerado". Cf. Origens do Totalitarismo. São Paulo: Companhia das Letras, 1989, pp. 488-489.

${ }^{270}$ Belmonte. A Mulher e os Filhos. Crônica publicada na Folha da Noite (São Paulo) em 19/09/1933, p. 2.

${ }^{271}$ Cf. Luiz Nazário. “O Expressionismo e os meios de Comunicação”. In: GUINSBURG, J. (org.). O Expressionismo. São Paulo: Perspectiva, 2002, p.605.
} 
Inconformado com a ascensão Nazi-fascista à época, pois percebera parte de seu inédito potencial dominador e destruidor, Belmonte troça com os “novos governos fortes” e com a Europa, berço dessas "novidades” atordoantes, apontando o que havia de retrocesso, de irracional e de brutal nestas supostas modernidades e, também, nas entranhas de um continente que, nos últimos séculos, se impôs como paradigma de civilização ${ }^{272}$ para todo o mundo.

Se pensarmos sob o prisma ilustrado-liberal europeu, que valoriza, sobretudo, a felicidade humana, não haveria "progresso" em uma mãe se sacrificar para tentar alimentar bem seu filho, sendo que ele indubitavelmente marchará para a guerra, e tanto poderá matar como morrer precocemente, ou alimentá-lo driblando tantos obstáculos para que a morte prematura o leve. Que "surto civilizador" pode haver em uma comunidade nacional que acata docilmente as ordens de um governo marcadamente imperialista e extremamente autoritário, e que a faz caminhar em direção de um conflito militar? Seria a morte nas trincheiras “civilizadora”? Irredutível, o artista acena negativamente: "Isso é ainda uma prova de como a guerra é uma coisa fatal, infallivel, inevitavel. E durma-se com um barulho desses...”273.

Belmonte questiona em sua crônica, nas entrelinhas, a quem interessariam as guerras e o imperialismo, se sairiam os civis alemães com vantagens dessa empreitada bélica, que se configura em um problema “...fatal, incorrigível e inevitável.” Só se pode antever que, provavelmente, eles perderão parte de seus amigos, filhos e companheiros. A crônica sugere que o militarismo interessa especialmente aos governos ditatoriais e expansionistas, que, além de tudo, atiram toda a carga e a responsabilidade da criação das crianças sobre os ombros das mulheres. Daí a espantada incompreensão do escritor, ao constatar que "Em qualquer outro lugar, essas mulheres se levantariam logo contra o governo. Na Allemanha, porem, deu-se o contrario. Quase todas elas adheriram em massa ao hitlerismo e estão lutando heroicamente para 'bem alimentar' os filhos, isto é, os guerreiros." 274

Entre um misto de espanto e inconformismo, o artista denuncia a pretensão de domínio absoluto e o autoritarismo exacerbado, características das novas ditaduras fascistas. Parece antecipar argumentos como o do parágrafo abaixo, alertando que a ascensão do Nazi-fascismo na “...éra moderna" ${ }^{275}$ :

\footnotetext{
${ }^{272}$ Civilização tem o sentido de progressão, de uma coletividade que anda para frente; está indubitavelmente ligada a um pensamento otimista de superação de etapas.

${ }^{273}$ Belmonte. A Mulher e os Filhos. Crônica publicada na Folha da Noite (São Paulo) em 19/09/1933, p. 2.

${ }^{274}$ Idem, ibidem.

${ }^{275}$ Idem, ibidem.
} 
(...) É uma crise de civilização. O que está em crise é o projeto moderno de civilização, elaborado pela Ilustração européia a partir de motivos da cultura judeoclássica-cristã e aprofundada nos dois séculos subseqüentes por movimentos como o liberal-capitalismo e o socialismo. O projeto civilizatório da modernidade tem como ingredientes principais os conceitos de universalidade, individualidade e autonomia. A universalidade significa que ele visa todos os seres humanos, independentemente de barreiras nacionais, étnicas ou culturais. A individualidade significa que esses seres humanos são considerados como pessoas concretas e não como integrantes de uma coletividade que se atribui valor ético positivo à sua crescente individualização. A autonomia significa que esses seres humanos individualizados são aptos a pensarem por si mesmos, sem a tutela da religião ou da ideologia (...). Ora, esse projeto civilizatório está fazendo água por todas as juntas.”276

Belmonte, um legítimo descendente do ideário iluminista e progressista, constata, melancólico, entre o início da década de trinta e meados dela, a evidente decadência dos ideais Ilustrados de igualdade, individualidade e de autonomia. Em verdade, o artista procura desmascarar a espalhafatosa novidade política do século XX - o Nazi-fascismo -, denunciando quão retrógrada ela é; configura-se como diametralmente oposta à civilização (idealmente) racional e Ilustrada, originária da Europa ocidental dos séculos XVII e XVIII. Para Belmonte, a dita novidade carrega em si um inegável potencial de mergulhar as sociedades humanas na barbárie.

${ }^{276}$ Paulo Sérgio Rouanet. Mal-estar na modernidade: ensaios. São Paulo: Companhia das letras, 2003, p. 09. 


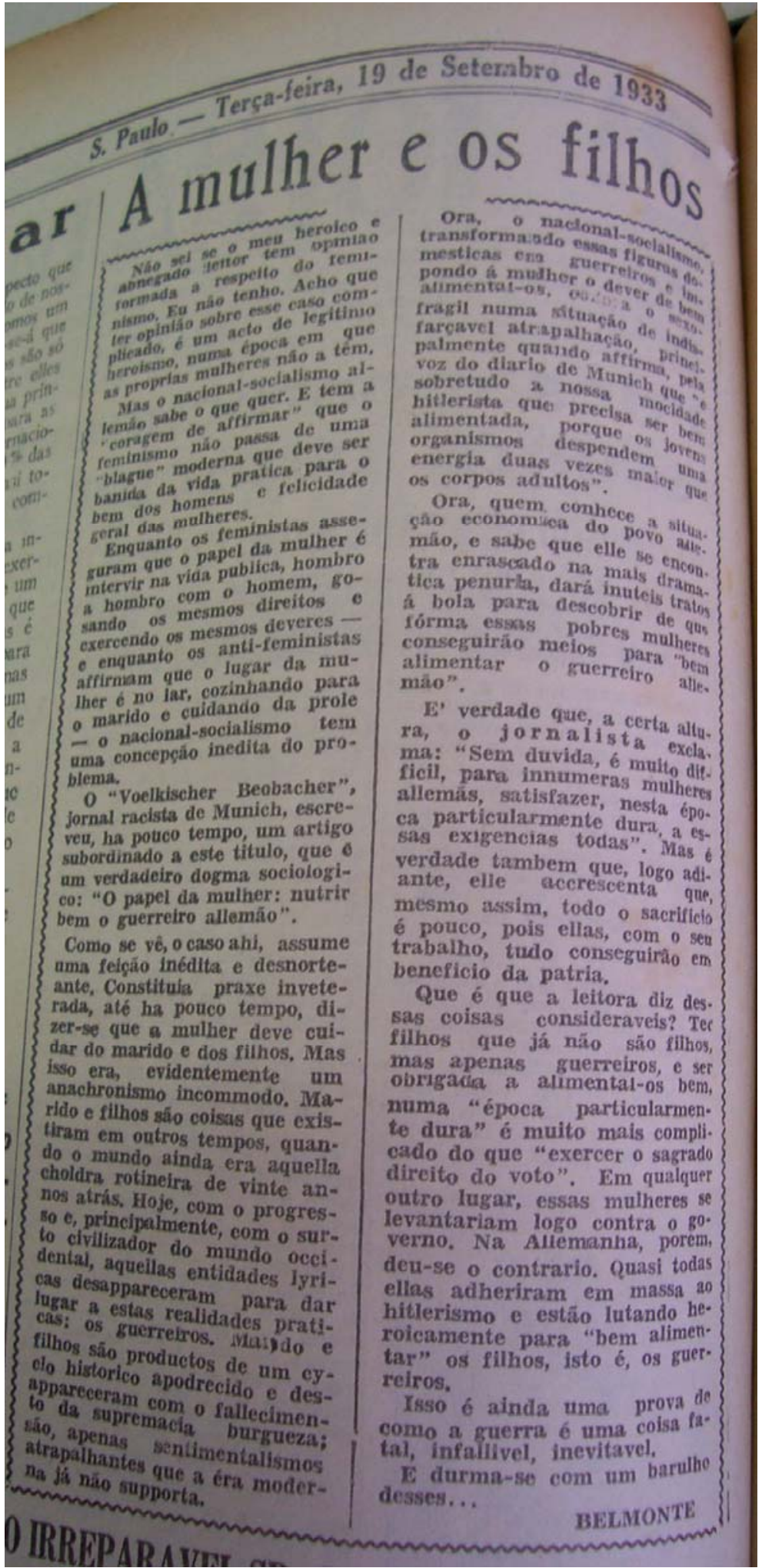

Fig. 9. A Mulher e os Filhos. BELMONTE.

Folha da Noite (São Paulo), 19/09/1933, p. 2.

Hemeroteca do Arquivo do Estado de São Paulo - AE/SP. 
O artista indaga às suas leitoras sobre o que acham da complexa situação das mulheres alemãs, que enfrentam uma tremenda penúria para alimentar suas crianças e o governo nazi, por sua vez, nada faz para lhes suavizar os duros encargos da maternidade. Perto das dificuldades impostas pelo Nazi-fascismo às mulheres, a exigência do voto feminino é evidentemente menos complicada, sendo exageradas as discussões criadas em seu entorno:

Que é que a leitora diz dessas coisas consideraveis? Ter filhos que já não são filhos, mas apenas guerreiros, e ser obrigada a alimental-os bem, numa 'época particularmente dura’ é muito mais complicado do que 'exercer o sagrado direito do voto'. Em qualquer outro lugar, essas mulheres se levantariam logo contra o governo. Na Allemanha, porem, deu-se o contrario. Quase todas elas adheriram em massa ao hitlerismo e estão lutando heroicamente para 'bem alimentar' os filhos, isto é, os guerreiros. $^{277}$

Ao requerer a opinião de suas leitoras, Belmonte aponta a alfabetização e a educação femininas nos meios urbanos brasileiros, que progrediam mais rapidamente do que nas localidades rurais. Não por acaso, muitas das propagandas impressas na Folha da Noite eram dirigidas às mulheres das camadas médias e altas: produtos de higiene pessoal (em especial sabonetes e cremes dentais), remédios contra diversos incômodos - azia, dores de cabeça e até para "aqueles dias” do mês nos quais senhoras e senhoritas não se sentem muito dispostas -, tônicos infantis, casas de alfaiataria e grandes magazines. É importante ressaltar, também, que as primeiras décadas do século XX assinalaram a vendagem de algumas revistas direcionadas especificamente para o público feminino. Em São Paulo, ganhou destaque a Revista Feminina, que tinha uma excelente distribuição e contava com a participação de jornalistas e escritores de importância. Ela foi publicada de 1914 a $1936^{278}$.

E no começo dos anos trinta, os debates sobre a situação feminina foram particularmente efervescentes no Brasil, pois as mulheres tiveram o direito de voto assegurado em 1932 - pela primeira vez na história do país ${ }^{279}$. Logo, era interessante para Belmonte propagar, junto a esta nova

\footnotetext{
${ }^{277}$ Belmonte. A Mulher e os Filhos. Crônica publicada na Folha da Noite (São Paulo) em 19/09/1933, p. 2.

278 Em suas páginas se desdobravam, com freqüência, embates entre posições feministas e conservadoras, sendo estas últimas divulgadas com mais freqüência pelo periódico.

Cf. Marina Maluf; Maria Lucia Mott, op. Cit., p. 369 e p. 639 (notas).

Ver também o artigo:

Sandra Lúcia Lopes Lima. “Imprensa feminina, Revista feminina. A imprensa feminina no Brasil”. Projeto História. São Paulo: PUC/SP, 35: 221/241, dez 2007.

${ }^{279}$ Apenas o Estado do Rio Grande do Norte permitiu este direito às mulheres antes de 25 de fevereiro de 1932. Cf. Edgard Carone, op. Cit., p. 174.
} 
parcela do público leitor (e eleitor), suas opiniões e concepções sobre o Nazi-fascismo e ideários políticos similares.

Em outra de suas crônicas sobre o Nazismo, o artista traz novamente à baila a estruturação e a coordenação militarizada da sociedade germânica sob o regime de Hitler. Nela, todas as esferas da vida pública e privada dos alemães compreendem a preparação para uma guerra:

O mundo, arrastado por ideologias complicadíssimas, vae tomando um rumo incerto e inquietante. E as mulheres, envolvidas nesse turbilhão exótico, estão se conduzindo para um destino que tem arripiado de horror os cautos cidadãos inimigos da subversão da ordem doméstica (...). Ainda a poucos dias em Berlim, na presença do 'ReichFuehrer', uma excelente senhora, 'frau’ Trude Mohr,pronunciou uma conferência. Antes de mais nada fique patente que 'frau' Trude é uma das educadoras officiaes da Liga das Jovens Hitlerianas, razão por que as suas declarações se revestem de um cunho de indisfarçável importância. Pois a senhora Trude Mohr, após fazer uma exhaustiva digressão sobre a mulher germânica, desde os tempos lendários e heróicos ate o presente, terminou affirmando que as jovens allemãs de hoje devem, como as suas valentes ancestraes, trazer uma espada no momento do matrimonio.

Não sei se essa espada, scintillando no punho da noiva em momento tão pouco propicio a militarismos, terá apenas uma feição symbolica ou se terá uma existência real, concreta, perfuro-cortante, na vida conjugal (...). De um modo ou de outro, o certo é que o sexo forte está estatelado diante de um problema inquietante. A não ser que, no momento do matrimônio, a noiva empunhe sua espada mas o noivo traga um fuzil Mauser sob o braço e uma pistola automática no bolso. [grifos nossos]

E que ambos, assim armados conservem o seu sorriso... ${ }^{280}$

Nota-se que o receio do escritor frente aos regimes políticos de extrema-direita é colocado logo na primeira linha da crônica, quando ele afirma que o mundo estava sendo arrastado por ideologias complicadíssimas, e tomava um rumo incerto e inquietante.

Belmonte denuncia o incentivo à belicosidade no Nazismo, que era incansavelmente disseminada na educação, nos clubes, na interpretação da história alemã e até na cerimônia de casamento. Esta, a celebração da constituição familiar (instituição que era um dos principais

${ }^{280}$ Belmonte. A Espada da Noiva. Crônica publicada na Folha da Noite (São Paulo) em 24/10/1934, p. 2. 
alicerces da sociedade germânica à época ${ }^{281}$, que, notadamente, valorizava a família numerosa ${ }^{282}$ ) se viu obrigada a incluir outro modelo de vida para a comunidade, ainda mais exacerbado depois da ascensão do partido Nacional-Socialista: o aparato militar, que simbolizava a suposta tradição guerreira da Alemanha (a espada da noiva) e o equipamento bélico moderno (carregado pelo noivo, configurado em seu fuzil Mauser e na pistola automática).

Assim unidos no altar, mulher e homem fascistas portavam não apenas seus paramentos nupciais como também vinham acompanhados de seus equipamentos de guerra, cuja exibição tornouse indispensável em qualquer esfera da vida social. E, assim, os jovens juravam fidelidade eterna não só entre si, como também se comprometiam a engajarem-se na(s) futura(s) guerra(s) conduzida(s) pelo infalível Führer contra povos considerados inferiores ${ }^{283}$. Nos discursos de Hitler, apenas os arianos deveriam ser dignos de uma vida repleta de conquistas, tendo, devido a sua superioridade, direito às terras de outras nações e às suas riquezas minerais e naturais.

Belmonte aponta também para a evidente contradição da união casamento/armas. No ideário burguês e liberal, o casamento é a esperança de duas vidas em comunhão, além de inaugurar a possibilidade de gerar novas vidas. Nada mais contrastante frente ao criar do que pré-determinar que os nascituros, ou aqueles que ainda nem foram gerados, dali a alguns anos, partiriam para a guerra e arriscarão suas vidas. Na sociedade alemã nazificada, perante o nascimento de um bebê do sexo masculino, já era projetada sua utilidade e, concomitantemente, sua possível morte, o que, para as sociedades liberais e burguesas, configura-se em um brusco choque entre as leis naturais de vida e falecimento. Para elas, a vida recém-chegada é o extremo oposto da morte.

Em uma outra crônica, Belmonte novamente repudia a difusão do ideário Nazi-fascista, larga e ostensivamente disseminado em alguns países europeus, especialmente na Alemanha e na Itália. Como não podia deixar de ser, o artista centra a sua carga contra a exaltação do belicismo e a padronização dos seres humanos. Desta vez, a temática central de seu escrito é a infância, são os garotos - futuros soldados a serviço dos ditadores:

\footnotetext{
${ }^{281}$ Segundo Wilhelm Reich, “...a família não pode ser encarada como a base do Estado autoritário, mas apenas como uma das mais importantes instituições que lhe servem de apoio. Mas temos de considera-la como a principal célula germinativa da política reacionária, o centro mais importante de produção de homens e mulheres reacionários”. Ver Wilhelm Reich. Psicologia de Massa do Fascismo. São Paulo: Martins Fontes, s/d, p.99.

282 “A ideologia da 'felicidade da família numerosa' é necessária não apenas para a preservação da família autoritária, mas também serve aos interesses do imperialismo bélico”. Cf. em Wilhelm Reich. op. Cit., p. 100.

283 “Nesse imaginário modelador da realidade, o guerreiro viril desposava a camponesa fértil, e o casal racialmente puro proliferava para fornecer ao regime uma massa de soldados superiores, destinados a perpetuar a guerra. Hitler declarou que, se tivesse criado um sistema familiar com duas crianças, o regime teria fracassado. Agora, numa família de cinco ou seis filhos, dois ou três podiam morrer no campo de batalha, e ainda sobrariam dois ou três para reproduzir mais cinco ou seis, eternizando a guerra”. Cf. Luiz Nazário. “O Expressionismo e o Nazismo”. In: GUINSBURG, J. (org.). O Expressionismo. São Paulo: Perspectiva, 2002, p.665.
} 
A guerra européa eriçou o mundo de problemas allucinantes $e$ as próprias crianças, hoje, quando surgem no mundo, não sabem como forrar-se ao contato híspido do drama que se desenrola no scenário universal. A humanidade, quanto mais estuda esses problemas, no afan desesperado de resolvel-os, mais se afunda em complicações terríveis. Sente-se que o homem não póde, não sabe concertar esta bola em que vivemos. E os estadistas, certos dessa verdade, estão appellando para as crianças, a vêr se estas, daqui a alguns annos, poderão realizar aquillo que elles, hoje,não conseguem fazer.

Mussolini e Hitler estão empenhados nessa tarefa. E as pobres crianças italianas e allemãs, mal surgem para a vida, são obrigadas a aprender política e a se metterem em tremendíssimas complicações partidárias, realizando arrazadoras paradas e exercícios, fazendo 'meetings', praticando esportes, suando nacionalismo por todos os poros, enfim, levando quase uma vida de caserna, material, realista, desencantada. É expressamente prohibido pensar em paz, em abstrações, em fantasias. Não se admittem mais gnomos, duendes, fadas ou infantilidades semelhantes. É o desencanto integral, o mais doloroso de quantos desencantos se tenham dado na face da terra. Nos cinemas allemães, os garotos de hoje não se deliciam mais com as disparadas de Tom Mix, com as aventuras de Tarzan ou com os disparates de 'crazzy cat': vêem apenas paradas hitlerianas, aspectos da grandeza germânica e ouvem discursos do 'Fuhrer', hymnos á guerra, blasphemias contra os pacifistas... ${ }^{284}$ [grifos nossos]

As crianças alemãs e italianas de então, qualificadas pelo escritor como "pobres” - porque tolhidas em sua espontaneidade e nas fantasias -, são forçadas pelos seus respectivos regimes políticos a uma rígida homogeneização do gosto e do caráter ${ }^{285}$. Devem praticar esportes sem trégua, com o fim de se prepararem fisicamente para os futuros conflitos imperialistas da Pátria (“...realizando arrazadoras paradas e exercícios...suando nacionalismo por todos os poros, enfim, levando uma vida de caserna...”) e devem idolatrar o líder e as guerras. Nada nos países fascistas, em

\footnotetext{
${ }^{284}$ Belmonte. As Crianças. Crônica publicada na Folha da Noite (São Paulo) em 12/07/1933, p. 2.

285 “' 'A pessoa não é nada 'em si', ela só é personalidade enquanto está integrada, em alma e espírito, numa cadeia orgânica de milhares de gerações’. Anulando o indivíduo em prol da corrente sanguínea, Rosenberg eliminava a responsabilidade pessoal como fundamento da liberdade. Dissolvido na horda, o homem seria pura determinação dos caracteres somáticos herdados dos antepassados. Como nas tribos primitivas, os ancestrais voltavam a ser o motor da vida, fazendo sucumbir toda ética”. Cf. Luiz Nazário. “O Expressionismo e o Nazismo”. In: GUINSBURG, J. (org.). O Expressionismo. São Paulo: Perspectiva, 2002, p. 34.
} 
especial na Alemanha, deve escapar do indubitável destino bélico, muito menos a educação das crianças, futuros soldados do glorioso amanhã e instrumentos para a sua materialização.

Nesta crônica que evidencia a brutalidade da educação nazista, onde a paz é hostilizada e a guerra e a Pátria são adoradas, Belmonte não perde a oportunidade de sublinhar o caráter profundamente autoritário do regime nazista. As palavras escolhidas pelo artista apontam isto: as crianças são “...obrigadas a aprender política...”, “É expressamente prohibido pensar em paz...”, “Não se admittem mais gnomos ou fadas” e “...as crianças vêem apenas paradas hitlerianas (...) ouvem discursos do Führer, hymnos á guerra, blasphemias contra os pacifistas”. Ao observarmos as linhas dessa crônica, não encontramos na sociedade alemã nenhuma voz que ouse se opor ao ideário Nazi-Fascista. Este é apresentado como um pensamento único, onipresente e absoluto, que não admite opiniões divergentes.

Na crônica As Bonecas, publicada no dia 2 de outubro de 1933, novamente a infância constitui-se na temática principal. Belmonte evidencia o objetivo Nazi-fascista de domínio total da sociedade e aborda a incisiva doutrinação das crianças alemãs pelo ideário nazista. Estas eram ensinadas a admirar o belicismo, o autoritarismo e iniciadas prematuramente no culto à personalidade do ditador, o chefe da nação:

...referi-me, ha dias á prosaica existência dos garotos nos paízes fascistas, obrigados a se desfazerem, a todo o custo, do seu temperamento fantasioso e ingênuo, para se integrarem no ‘espírito revolucionário’ da época.

Nada de sonhos, nem de fantasias. A meninada (sem allusão á ‘ala moça') está sendo convenientemente 'educada' no sentido de não acreditar mais em fadas, nem em gnomos - bobagens creadas pelo romantismo mórbido de antanho - e convencer-se de que na terra só existe um Príncipe Encantado: o dictador fascista. ${ }^{286}$

Belmonte alfineta o Nazismo com sua ironia. Quando o escritor coloca que na Alemanha “Não se brinca mais de 'pegador', nem de 'accusado', nem de 'barra manteiga'; brinca-se de parada, de cargas de baioneta, de jogar gazes asphyxiantes, de dar tiros de canhão...”287, ele conclui que tratase de “...coisas muito divertidas e muito educativas...”288 para se ensinar aos pequenos.

\footnotetext{
${ }^{286}$ Belmonte. As Bonecas. Crônica publicada na Folha da Noite (São Paulo) em 02/10/1933, p. 2.

${ }^{287}$ Idem, ibidem.

${ }^{288}$ Idem, ibidem.
} 
Mesmo com a perspicaz ironia belmontiana, por quase três quartos da crônica, o trunfo do regime nazista parece mais plausível: as crianças são colocadas submissamente; as garotinhas alemãs se vêem obrigadas a ninar um boneco uniformizado militarmente, e que representa Adolf Hitler, pois tem a sua cara. Um brinquedo que elas estranham, mas que lhes é imposto:

\begin{abstract}
As meninas que brincam com bonecas preferem sempre as bonecas-meninas, de cabellos sedosos e vestidinhos bonitos. Apraz-lhes ninar essas 'filhinhas' que não incommodam e que fecham os olhos quando deitadas e chamam 'mamã' quando levantadas. O maior enlevo das meninas de todo o mundo é pentear aquelles cabellos finos, fazer vestidinhos para as 'bebês', deital-as em caminhas minusculas...(...).

Mas ha de ser singularmente desagradavel obrigar-se uma garotinha de cinco annos a ninar uma boneca com a cara de Hitler. Por mais esforços de imaginação que ella faça, não chegará a compreender nunca por que estranhas razões a 'sua filhinha' veste calças, usa perneiras e ostenta um bigodinho petulante. É possivel que após algum tempo de encabulação ou de desespero, ella acabe perdoando o bigode. Mas nunca perdoará as calças nem as perneiras, porque ella nunca poderá conceber uma ‘filhinha' com tão exquisitas indumentárias”289 . [grifos nossos]
\end{abstract}

Entretanto, o zombeteiro Belmonte repentinamente vira a história a favor do lado mais fraco, e a frágil menina alemã termina por controlar uma imagem de Hitler completamente ridicularizada e patética: grosseiramente feminizada, ostentando concomitantemente o bigode e uma saia sobre as roupas militares. Essa inversão desprestigia a imagem do ditador. De forte e manipulador, ele passa a ocupar, na crônica, a figura da mais absoluta submissão: a de um boneco tateável e com a identidade sexual maculada. Se temos, até aproximadamente a metade da crônica, uma situação que parecia ser de poder para Hitler e o Nazismo, ela subitamente transforma-se em seu avesso:

O que sucederá?

A garota, na sua infinita candura, acabará fazendo umas saias para cobrir as calças pardas do dictador. Ella não entende de política; não sabe que 'isso não se faz’. E o

${ }^{289}$ Idem, Ibidem. 
dictador ficará mesmo de saias, no collo da menina que, á noite, o embalará com carinho, cantarolando para que elle adormeça. ${ }^{290}$

Desta forma, o artista causa danos à imagem do chanceler alemão, pois a descrição imagética do Führer de saias, no colo de uma garotinha e por ela manipulado, é bastante eficiente. Propagador de uma ideologia assaz valorizadora da força masculina, do guerreiro ${ }^{291}$, e de desqualificação do sexo feminino - apontado como fraco e menos inteligente, cuja única atribuição deveria se restringir a atividades domésticas e maternas - ele, o chefe da Alemanha, subitamente passa ao controle de uma menina. Coisificado, a ação lhe é completamente tolhida. O até então poderoso e intocável Hitler transforma-se em um brinquedo inanimado, manipulado à sua revelia por um dos mais indefesos dos seres humanos (segundo o ideário nazista), posto que este é apresentado como feminino e infantil.

Belmonte revela tamanha habilidade em descrever o líder nazista vestido de "mulherzinha”, que conseguimos compor mentalmente essa imagem, e com facilidade. É certo que a visualização da imagem de Hitler de saia só era (e é) possível aos leitores porque se tratava de uma personalidade pública muito conhecida e fotografada pela imprensa. Evidentemente, eles não portavam quaisquer dúvidas de que o boneco feminizado é apenas uma representação de Hitler. De qualquer modo, nesta crônica, o artista procura apanhar um ato instintivo e automático de nosso pensamento, o de associar imediatamente uma imagem do indivíduo com o mesmo, como se ela fosse ele de fato. Este pensamento instintivo, irracional e instantâneo atribui à imagem o poder de impingir benefícios ou malefícios à pessoa por ela representada

O historiador da arte Ernest H. Gombrich explica o processo desse pensamento:

Não penso que seja realmente difícil reavermos esse sentimento. Tudo o que precisamos é sermos profundamente honestos conosco e apurarmos se em nosso próprio íntimo não se conserva também algo de ‘primitivo'. Em vez de começarmos com a Época Glacial, principiemos por nós mesmos. Suponha-se que recortamos um retrato do nosso campeão favorito no jornal de hoje: sentiríamos prazer em apanhar uma agulha e picotar-lhe os olhos? Isso nos seria tão indiferente quanto se os furos tivessem sido feitos em qualquer outra parte do jornal? Penso que não. Embora eu saiba, com os meus pensamentos despertos, que o que eu fizer ao seu retrato não fará

\footnotetext{
${ }^{290}$ Idem, Ibidem.

291 Cf. Luiz Nazário. “O Expressionismo e seu Contexto. 1. Quadro Histórico”, in: GUINSBURG, J. (org.). O Expressionismo. São Paulo: Perspectiva, 2002, p. 34-35. Ver, do mesmo autor “O Expressionismo e o Nazismo”, in: op.cit., p. 662-665.
} 
diferença alguma ao meu amigo ou herói, sinto, não obstante, uma vaga relutância em causar danos à sua imagem. Subsiste algures a sensação absurda de que o que se faz ao retrato é infligido à pessoa que ele representa. Ora, se estou certo nesta suposição, se esta idéia estranha e irracional realmente sobrevive até mesmo entre nós, em plena era da energia atômica, talvez seja menos surpreendente que tais idéias existissem entre quase todos os chamados povos primitivos. ${ }^{292}$

Ao apresentar essa imagem desfavorável e ridícula de Hitler, Belmonte o inferioriza perante os leitores e pode torná-lo motivo de riso. Mas ao mesmo tempo em que ri de Hitler e do Nazismo, o artista coloca para o leitor, nas entrelinhas, a necessidade de se pensar sobre a possível ameaça de suas pretensões imperialistas e autoritárias. Acompanhemos essa interessante finalização da crônica:

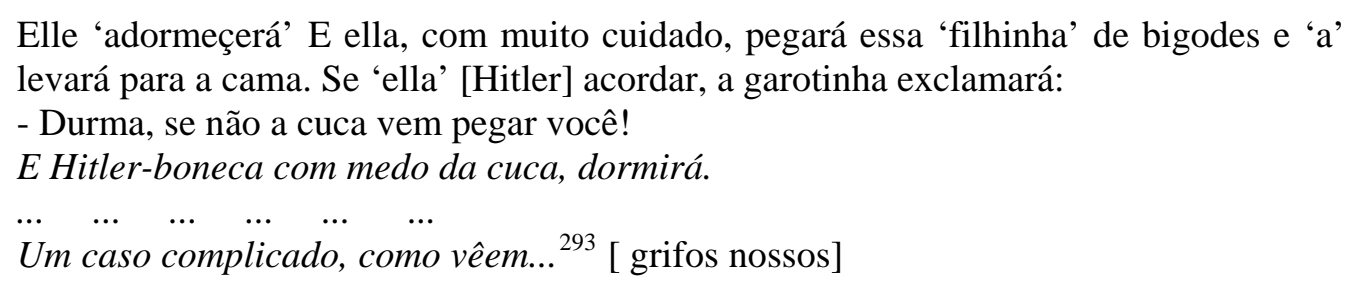

A zombaria de Belmonte novamente se coloca para (re)lembrar o leitor de que Hitler não é ella, uma inofensiva boneca, e sim o líder de um ideário político preocupante, porque expansionista e dominador, e que não sossegará (adormecerá) tão facilmente.

O escritor consegue competentemente provocar o riso no leitor e, ao mesmo tempo, chamá-lo à reflexão sobre a complexidade da política da época. O riso, por sua vez, surge pela quebra da previsibilidade proporcionada pela súbita inversão do papel político e sexual do então poderoso chanceler Adolf Hitler. Relembremos Sigmund Freud, para quem o humor (ou seja, os chistes, as piadas e as palavras espirituosas) quebra a nossa rigidez comportamental porque contem uma ruptura de determinismo, de previsibilidade ou de lógica. ${ }^{294}$

Bonecos e homens travestidos de mulheres foram alegorias usadas algumas vezes por Belmonte com o objetivo de expressar a debilidade de alguém. Em épocas mais machistas e militaristas, como foram as primeiras décadas do século XX, o homem vestido com roupas femininas configurava-se em uma alegoria particularmente provocativa e desabonadora para aquele que era representado dessa forma. O artista usou-a especialmente nas suas charges. Até aproximadamente a

\footnotetext{
${ }^{292}$ Cf. Ernest H. Gombrich. História da Arte. São Paulo: Círculo do Livro/Zahar, s/d, p. 20.

293 Belmonte. As Bonecas. Crônica publicada na Folha da Noite (São Paulo) em 02/10/1933, p. 2.

294 Sigmund Freud, op. cit., pp. 34-35.
} 
metade da Segunda Guerra Mundial, os países invadidos pela Alemanha eram retratados como bonequinhas, cada qual vestida com a roupa típica de sua nacionalidade, e Hitler se empolgava ao manipulá-las. Os países vencidos ou que estavam em vias de serem conquistados belicamente pelos nazistas eram também retratados como belas jovens. Mas no final da guerra, o líder alemão foi muitas vezes desenhado por Belmonte travestido de mulher, denotando fragilidade (nesse caso, militar e física) e estampando o ridículo. 
"O PIOR SURDo í AQUELE QUE NÃO QUER OUVIR..."

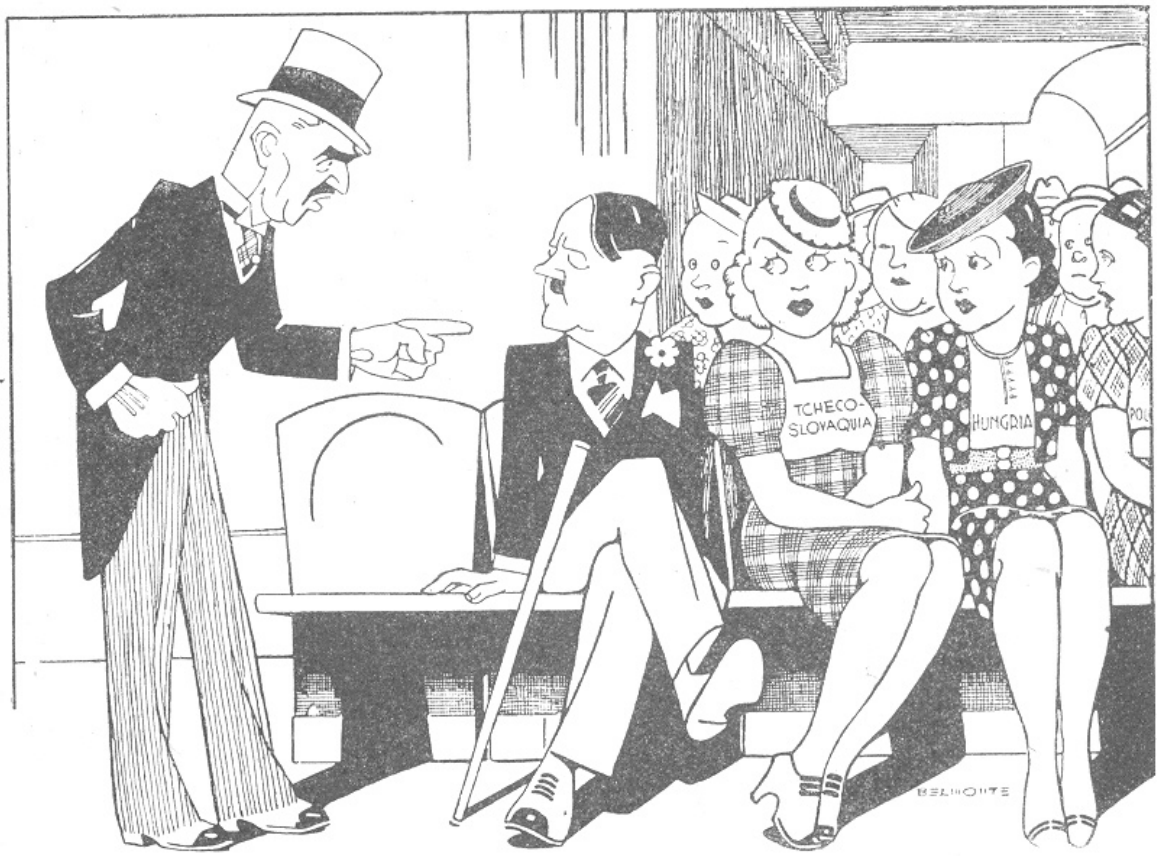

- Há muito tempo que o Sr. está aí incomodando minha afilhada! Falemos claro: as suas intenções são boas?

- Não senhor!

- Ah! Bem! Pensei que as suas intenções não eram boas..

Fig. 10. Caricatura dos Tempos. BELMONTE. São Paulo: Melhoramentos, 1948, p. 19.

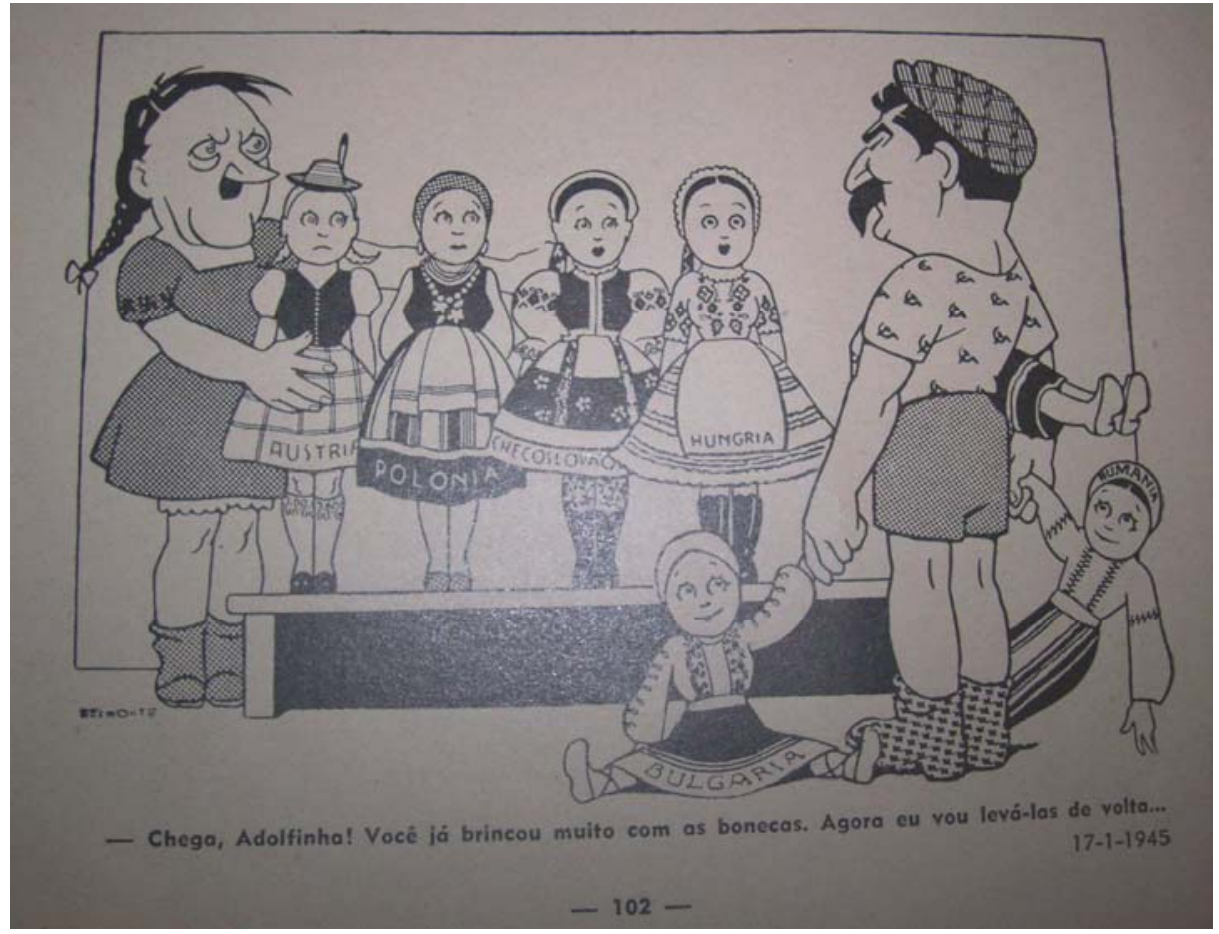

Fig. 11. Caricatura dos Tempos. BELMONTE. São Paulo: Melhoramentos, 1948, p. 102. 
As atitudes inusitadas e singulares da pequena personagem da crônica sobre o esquisito boneco de Hitler denotam que, de vez em quando, o costumeiro pessimismo de Belmonte arrefecia, e ele apostava que a criatividade humana e a sua imprevisibilidade demoliriam o regime Nazi-fascista e as demais formas de autoritarismo. Nesse sentido, esta bela crônica sugere esperança nas ações humanas e em suas diversas possibilidades.

Nesta crônica, o escritor-caricaturista destaca também o aspecto subversivo inerente ao humor. Na Alemanha, os bonecos dos líderes nazistas deveriam ter as características faciais mais próximas possíveis do rosto do indivíduo representado. As faces caricaturadas são rejeitadas pela cúpula nazista, porque exageradas ou distorcidas, pois podem facilmente fazer resvalar para a sátira e o riso, e não para a admiração submissa dos chefes, que seria a proposta essencial da feitura desses bonecos. Logo, o humor é potencialmente o desvirtuamento do planejamento rígido, pré-concebido e organizado, e, justamente por ser assim, tão contraproducente e, portanto, perigoso, deve ser banido por completo pelo poder:

\begin{abstract}
Em Sonnemberg, na Thuringia, dois fabricantes confeccionaram bonecas de panno representando homens das secções de assalto. Mas tendo lhes dado aspecto caricatural, a direcção da secção local do partido qualificou esse processo de abuso inadmissível”. É sabido que, na Allemanha de hoje, é surpreendente a producção de bonecas representando Hitler, Goering, e outros próceres nazistas. Mas, como se vê, essas bonecas não podem ter aspecto caricatural. As meninas que brincarem com essas 'bonecas', precisam ter uma idéia exacta, e não deformada, da physionomia dos heróes racistas. ${ }^{295}$
\end{abstract}

Na interessante crônica Na Corda Bamba..., de 06 de abril de 1933, Belmonte denuncia o chauvinismo alemão. Nela está estampado que, na Alemanha sob jugo do Nazismo, o único povo merecedor de "salvação" (leia-se: de sobrepor-se aos outros países) deve ser o alemão e aquele que cultural e racialmente mais se aproxima dele: o austríaco. O bem-estar das outras "raças” do globo terrestre não lhe interessa em absoluto. Aliás, são encaradas como nocivas, porque corruptoras dos costumes teutos, indubitavelmente superiores, segundo a ótica do Nazismo.

O artista dá início à sua crônica contando que o sentimento de desamparo em sua época era geral. Todos os povos se angustiavam com as crises sociais e a instabilidade da contemporaneidade. Por isso, prossegue Belmonte, há tantos partidos e manifestos surgindo por aí: “Não há como conter

${ }^{295}$ Belmonte. As Bonecas. Crônica publicada na Folha da Noite (São Paulo) em 02/10/1933, p. 2. 
essa erupção alarmante de papéis escriptos. Onde há um homem insatisfeito, há uma idéia salvadora. E onde dois homens insatisfeitos se encontram, explode um programma, estruge um manifesto”296.

Ele relata que no início da enxurrada de manifestos, gostava muito de ler as inúmeras propostas. Mas logo elas se tornaram tantas, e tão semelhantes umas com as outras - "E cada partido que surge, enche os espaços de ideologias novas, concretizadas em manifestos velhos." ${ }^{297}$-, que ele se cansou e abandonou esse costume.

Agora, entretanto, Belmonte se vê forçado a atentar para uma destas ideologias, que, segundo ele, trata-se da mais séria que surgiu nos últimos quinze anos, ou seja, desde o final da Primeira Guerra Mundial. A mais “séria” pode ter o sentido de mais consistente, como pode, também, significar que é a mais problemática ou perigosa de todas, o que é mais provável, conhecendo-se a opinião do escritor sobre o Nazismo:

Agora, porem, abro uma excepção para registrar, nessas columnas graves, o mais sério de quantos manifestos têm surgido por ahi, nestes últimos quinze annos.

A Allemanha é o berço deste notável documento (...) a synthese que o telegrapho nos dá de tal sensacional manifesto, basta para que eu o considere o mais expressivo documento neste século de ideologias confusas e diffusas”298 ${ }^{29}$ [grifos nossos]

No sétimo parágrafo, o artista coloca que esse programa inédito não é especificamente político, pelo menos não no sentido estrito do termo. Trata-se de um grupo alemão de professores de dança que defende intransigentemente a prática de se bailar apenas músicas nacionais. $\mathrm{O}$ andamento da crônica, entretanto, irá contradizer a afirmação inicial do escritor, sugerindo imbricações estéticas e políticas: "Como se vê, os allemães podem continuar dansando na corda-bamba mas, se não quizerem levar um trambolhão dramático, precisam dansar em allemão (...).Quem dansar 'ideologias' exóticas, estará frito".

Atentemos para a auto-ironia de Belmonte, manifestada nas palavras "nessas columnas graves”. Muito costumeiramente, o artista zombava de si e de suas crônicas, qualificando-as de tolices que ele “escrevinhava” aos seus “heróicos” leitores ${ }^{299}$.

Prosseguindo com a crônica, podemos observar como Belmonte a conduz. Ainda que ele jamais tenha usado as palavras "Nazismo”, “Nazi-fascismo”, ou até mesmo “Hitler”, permanece subentendido para o leitor arguto que os professores de dança de Berlim apóiam, com clara

\footnotetext{
${ }^{296}$ Belmonte. Na Corda Bamba... Crônica publicada na Folha da Noite (São Paulo) em 06/04/1933, p. 2.

${ }^{297}$ Idem, Ibidem.

${ }^{298}$ Idem, Ibidem.

${ }^{299}$ Cf. Belmonte. Nós e elles. Crônica publicada na Folha da Noite (São Paulo) em 31/08/1934, p. 2.
} 
evidência, diretrizes estético-culturais do Nazismo. Primeiramente, eles impõem apenas as danças calcadas nas melodias germânicas; todas as outras são inadequadas ou "perigosas” 300 , com exceção das austríacas, “quase alemãs”. Em segundo lugar, os professores de dança buscam “resolver” apenas as angústias e problemas dos seus compatrícios; todo o restante do mundo é ignorado e, porque não, renegado:

Que pretendem elles?

Num momento em que a humanidade toda está, afflictamente, realizando um dramático bailado na corda bamba, não é motivo de pasmo sahirem, os professores de dansa do seu silêncio para ministrarem aos povos, com a autoridade que todos nós lhes reconhecemos, conhecimentos úteis acerca da melhor maneira de prosseguirmos nessa coreographia trágica, sem os riscos de degringolarmos do alto da corda.

Não é isso, comtudo, o que eles querem. Infelizmente, o problema que os bailarinos germânicos pretendem resolver são localíssimos. Sómente a Allemanha poderá colher os frutos de tão benficas idéas emquanto que nós outros, sem dançarinos manifestantes, continuaremos sobre a corda bamba, dansando arbitrariamente, expostos a todos os riscos possíveis e impossíveis.

Os professores allemães, nesse manifesto sensacional, estudam a actual situação política da Allemanha e, depois de várias considerações de ordem social e musical, citando Bismarck e Terpsycho[?] asseguram que 'as dansas de hoje - o tango o 'foxtrot' e o ‘charleston’ - não correspondem, pelo seu caracter, ás aspirações do povo allemão’.

Como se vê, os allemães podem continuar dansando na corda-bamba mas, se não quizerem levar um trambolhão dramático, precisam dansar em allemão. As dansas estrangeiras são perigosas - salvo a austríaca que é quase nacional. Assim a valsa, a mazurka e a polka são as 'ideologias’ mais applicáveis ao grave problema políticodansante da grande terra de Wagner. Quem dansar 'ideologias' exóticas, estará frito. Fóra da mazurka não há salvação.

Os professores teutos enveredam, pois, pelo bom caminho, descobrindo as verdadeiras 'aspirações' da Germânia. ${ }^{301}$ [grifos nossos]

Além do nacionalismo extremado, característica essencial do Nazismo, percebe-se que esta decisão dos professores alemães tem um quê de autoritário, pois eles sabem, de antemão, quais são as

\footnotetext{
300 "Todos os regimes fascistas tentaram controlar a cultura nacional de cima para baixo, purificá-la de influências estrangeiras e transforma-la num veículo da mensagem de unidade e revivescimento nacionais”. Cf. Robert Owen Paxton, A Anatomia do Fascismo. São Paulo: Paz e Terra, 2007, p. 239.

${ }^{301}$ Belmonte. Na Corda Bamba... Crônica publicada na Folha da Noite (São Paulo) em 06/04/1933, p. 2.
} 
“verdadeiras aspirações da Germânia”. A própria expressão “aspirações do povo alemão” integrava uma idéia muito disseminada pelo governo nazista à época: a de um povo uno, com uma só necessidade $^{302}$, conduzido por um guia quase que predestinado, descobridor original da vontade de seu povo, que o levaria para a conquista de seu glorioso destino.

Não por acaso, no mesmo período, algo muito próximo desta idéia era também disseminado no Brasil pelo governo autoritário de Getúlio Vargas. Em um discurso que o político gaúcho pronunciara na posse da chefia do Governo Provisório, perante a Junta Governativa, em 3 de novembro de 1930, lê-se o seguinte:

\begin{abstract}
O movimento revolucionário, iniciado, vitoriosamente, a 3 de outubro, no Sul, Centro e Norte do país, e triunfante a 24, nesta Capital, foi a afirmação mais positiva que, até hoje, tivemos da nossa existência como nacionalidade. Em toda a nossa história política não há, sob esse aspecto, acontecimento semelhante. Ele é, efetivamente, a expressão viva e palpitante da vontade do povo brasileiro, afinal senhor de seus destinos e supremo árbitro de suas finalidades coletivas (...)." ${ }^{303}$ [grifos nossos]
\end{abstract}

Aspiração, espírito, vontade do povo. Essas expressões convergem para a idéia de uma nação onde todos os compatriotas comungam do mesmo pensamento, e na qual a manifestação de concepções diversas é incomum, destoante. A referência à opressão que grassava naquele país está presente na crônica: quem não acatasse a decisão dos mestres, que representam alegoricamente o Nazismo ou o partido nazista, de banir melodias e danças exógenas, estaria “frito”, sugerindo, nas entrelinhas, que havia um aparato de repressão atuante. Assim, ao aproximar o regime político alemão do brasileiro por meio de certas expressões, Belmonte chamava seu leitor à reflexão sobre o discurso e a ação pouco democráticos do governo de Getúlio Vargas.

Nessa crônica, o artista buscou contrastar o sentimento de superioridade e exclusividade alemã do Nazismo com o sentimento generalizado de angústia dos povos, que enfrentavam graves crises políticas e econômicas, especialmente após a I Guerra Mundial e o crash de 1929. Se o desamparo se espalhou por todo o mundo, a ponto de se saber de manifestos escritos em inglês, em chinês, alemão, hebraico, esperanto e até na misteriosa língua “volapuk”304 (2ºrágrafo da crônica),

\footnotetext{
302 “Joseph Goebbels declarou, em uma cerimônia de queima de livros realizada em Berlim , em 10 de maio de 1933, que 'a era do extremo intelectualismo judaico havia agora terminado, e que o sucesso para a revolução germânica havia novamente aberto caminho para o espírito alemão”. Goebbels-Reden, v. I (1933-1939), ed. Helmut Hiber. Düsseldorf: Droste Verlag, 1971, p. 108, in: Robert Owen Paxton, op. Cit., p. 71.

303 Cf. Getúlio Vargas. A Nova Política do Brasil. I - da Aliança Liberal às realizações do primeiro ano de Governo 1930-1931. Rio de Janeiro: José Olympio, 1938, p. 69.

${ }^{304}$ Volapuque era uma língua que tinha a intenção de ser uma língua universal à época, tal como posteriormente o esperanto.
} 
com que autoridade os germânicos se posicionavam como superiores, sendo que aquele desamparo, intrinsecamente humano, irmanava todos os povos por meio dos sentimentos de fragilidade e desimportância? E como bem mostrou Belmonte, os alemães não eram exceção à regra, pois o país deles foi o berço do documento “...o mais sério de quantos manifestos tem surgido por ahí, nestes últimos quinze annos ${ }^{305}$.

Ao mesmo tempo em que o escritor critica o autoritarismo nazista e, indiretamente, o brasileiro, ele sugere que a adoção de medidas restritivas e antidemocráticas não aliviaria as dificuldades humanas. Pelo contrário, no sétimo parágrafo, ele esclarece que os professores germânicos de dança transmitiriam apenas conhecimentos úteis acerca de como prosseguir sobre a corda sem perder o equilíbrio e se “arrebentar”. De qualquer modo, as pessoas continuariam alegoricamente restritas ao limitado e inseguro caminho sobre a corda bamba imposto pelos governantes autoritários, sem possibilidade alguma de escaparem ao ameaçador trajeto e submetidas por completo a uma “coreographia trágica”, única alternativa se não quisessem ter sua integridade física ameaçada ou destruída.

\footnotetext{
${ }^{305}$ Belmonte. Na Corda Bamba... Crônica publicada na Folha da Noite (São Paulo) em 06/04/1933, p. 2.
} 


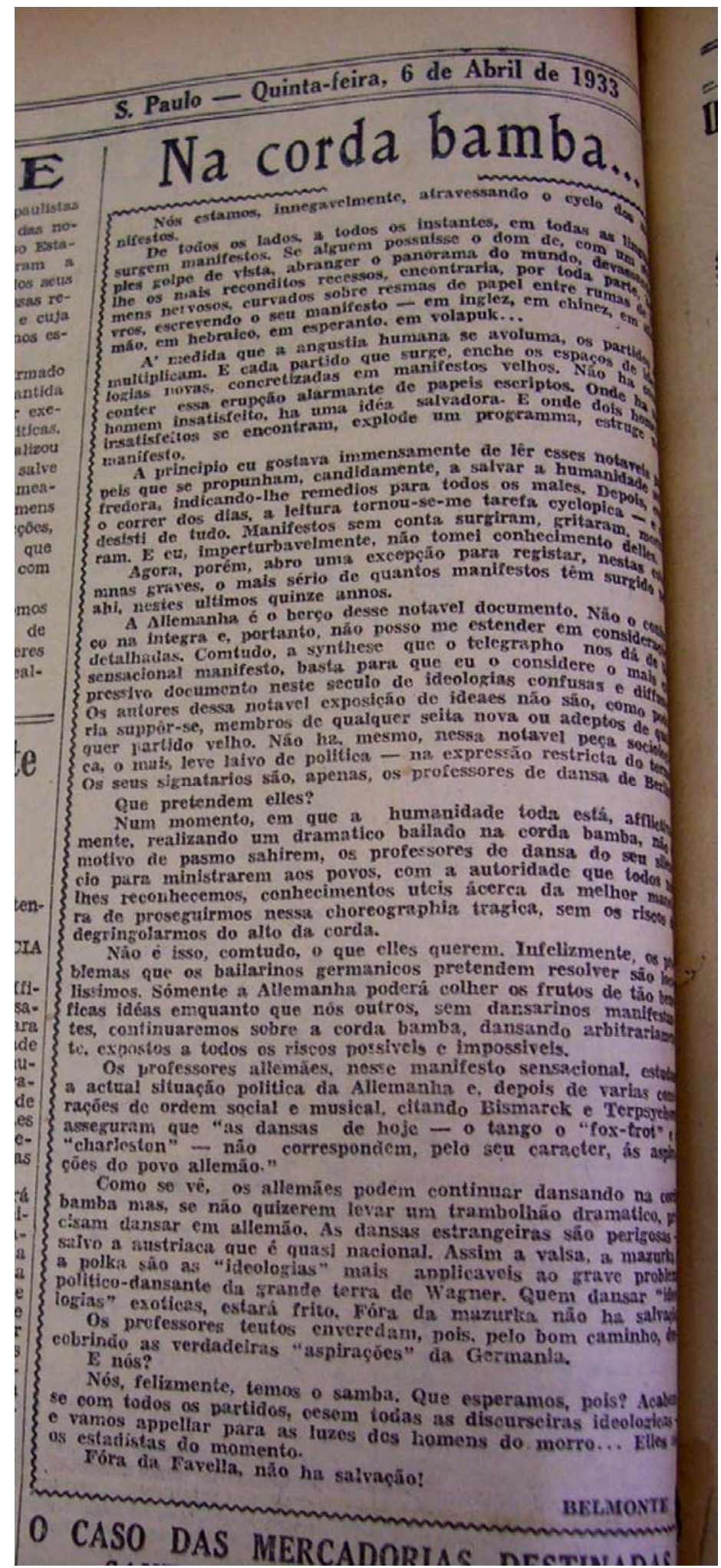

Fig. 12. Na corda bamba... . BELMONTE.

Folha da Noite (São Paulo), 06/04/1933, p. 2.

Hemeroteca do Arquivo do Estado de São Paulo - AE/SP. 
Na excelente crônica Opposição e Loucura, publicada a 17 de maio de 1933, o artista critica de novo o autoritarismo do Nazismo, mas sem explicitar o nome do partido em questão. Logo, assim como na crônica $\mathrm{Na}$ corda bamba, o artista pressupunha um leitor razoavelmente bem-informado, que teria possibilidade de associar o assunto do escrito com o novo e preocupante regime político que ascendeu ao poder na Alemanha:

Nesse poético recanto da Allemanha [Baviera], existe um Wagner que, pelos modos, não tem nenhum ponto de contacto com o seu famoso homonymo de Beyreuth. $\mathrm{O}$ Wagner das obras complicadas era, por assim dizer, um enamorado da desharmonia. E o Wagner de hoje, além de ser ministro, é um fetichista da ordem e da disciplina. Aquelle era um revolucionário das fusas e semi-fusas e, como tal, creava musicas que se caracterizavam, principalmente, pela indisciplina e pela rebeldia. Este, ao contrário, é um conservador renitente, que deseja crear um Estado harmônico e socegado, fazendo política como quem compõe valsas românticas dentro do velho estylo weldteutoliano.

Esse estado de espírito anti-revolucionario do ministro Wagner, acaba de manifestarse, mais fortemente, com as declarações que elle fez hontem, a propósito dos partidos políticos bávaros.

Declarou o assustadiço sr. Wagner que, na sua qualidade de responsável pela administração interna do Estado, não toleraria para o futuro nenhum partido político, porque o povo já está farto de partidos. E acrescentou que os partidos existentes só têm dois caminhos a seguir: ou adherem ao governo ou 'não poderão tirar conseqüência nenhuma de sua posição’.

Esta ultima alternativa é sybillina e atrapalhante porque ninguém sabe quaes seriam essas conseqüências. Suppõe-se, todavia, que a única conseqüência a tirar, seria a de serem os partidos rebeldes convidados a pentear macacos ou a lamber sabão.

Alias, esta minha conclusão não é completamente arbitraria. Ella provém de que $o s r$. Wagner, para explicar-se, declarou que os 'que quizessem adherir, seriam recebidos de braços abertos'; mas os que não o fizessem seriam 'classificados como loucos ou criminosos'. ${ }^{306}$ [grifos nossos]

Na Alemanha que figura na literatura de Belmonte, é marcante a total indisponibilidade dos novos governantes em conviver com outros partidos que não o NSDAP. E o Wagner Ministro da

${ }^{306}$ Belmonte. Opposição e Loucura. Crônica publicada na Folha da Noite (São Paulo) em 17/05/1933, p. 2. 
Baviera, por sua vez, decide em nome da população, afirmando que “...o povo já está farto de partidos".

Esta crônica provavelmente se referia aos acontecimentos políticos arbitrários ocorridos naquele país alguns meses antes da sua publicação. Em fins de fevereiro de 1933, o Reichstag (parlamento alemão) foi destruído pelas chamas. O incêndio foi tido como criminoso, e os nazistas acusaram os comunistas pelo atentado ${ }^{307}$. Logo, à ordem de repressão sobre estes últimos dada pelo chanceler - e efetuada por Goering -, seguiu-se aquela de perseguição aos judeus e opositores políticos do regime. A situação política alemã foi, progressiva e assustadoramente, se tornando asfixiante. Em princípios de março, após a eleição em que $90 \%$ da população deram $44 \%$ de votos ao NSDAP, os parlamentos regionais foram neutralizados e os judeus, democratas e militantes de partidos de esquerda perseguidos impiedosamente, especialmente os membros do Partido Comunista Alemão (KPD):

\begin{abstract}
Comemorando a vitória, turbas de SA percorreram as ruas e prenderam cerca de dez mil judeus, políticos, intelectuais, funcionários e líderes católicos, liberais, socialdemocratas e comunistas. Muitos foram torturados até a morte. Os nacional-socialistas instalaram, de imediato, mais de cem campos de concentração. ${ }^{308}$
\end{abstract}

No dia 8 de março de 1933, o governo de Hitler aumentou a repressão contra o Partido Comunista Alemão ao cassar os mandatos de seus deputados. Uma semana depois, o partido foi proibido. A proibição e perseguição dos partidos políticos de oposição configuravam-se, portanto, em acontecimentos recentes na Alemanha Nazista, e Belmonte procurou divulgá-los aos seus leitores por meio de um ponto de vista não-favorável aos hitleristas, apresentados como intolerantes e intransigentes.

Ao dar prosseguimento à leitura da crônica, percebe-se que aqueles que se recusassem a aderir ao partido Nazista seriam considerados loucos ou criminosos. No irônico parágrafo transcrito abaixo, o escritor aponta a apropriação da ciência pelo brutal poder político alemão de então, que a usava para desacreditar as discordâncias e diferenças que porventura surgissem no país. Nele está também explicitada a submissão dos conhecimentos científicos ao Estado e é sugerida a propensão do Nazismo ao domínio total:

\footnotetext{
307 “O atentado teria sido obra exclusiva do holandês mentalmente perturbado Marinus van der Lubbe. Mas Hitler já estaria preparado para impor o estado de exceção previsto no art. 48 da Constituição de Weimar, suspendendo as liberdades de imprensa e movimento”. Cf. Luiz Nazário. “O Expressionismo e seu Contexto. 1. Quadro Histórico”, in: GUINSBURG, J. (org.). O Expressionismo. São Paulo: Perspectiva, 2002, p.37.

${ }^{308}$ Idem, ibidem.
} 
Como se vê, o sr. Wagner não precisa socorrer-se das luzes de Lombroso ou de Cabanés para aquilatar o grau de criminalidade ou loucura dos chefes dos partidos bávaros. Basta que o político discorde das excellencias governamentais para que seja incluído no rol dos tarados ou dos dementes. A sciência nada terá que ver com isso, pois o Estado soberano tem obrigação de entender de tudo, inclusive de criminalogia e de psychiatria. ${ }^{309}$ [grifos nossos]

As décadas finais do século XIX e as primeiras décadas do seguinte constituíram-se, certamente, no período glorioso da eugenia, que objetivava o aperfeiçoamento físico, mental e racial dos seres humanos e sua profilaxia, relacionando-se assim, intimamente, com o higienismo. Para a eugenia, encarada seriamente como ciência à época, não eram somente as doenças como tuberculose, sífilis, epilepsia ou deformações físicas congênitas que ameaçavam de degenerescência os homens: distúrbios mentais e desvios de conduta também deveriam ser combatidos. Aos seus portadores, rejeitados e excluídos da convivência com pessoas "sadias”, restava o sombrio destino do isolamento, de preferência em instituições manicomiais e prisionais.

Na era das massas, a partir de fins do século XVIII, época em que milhares de trabalhadores anônimos de diversos níveis de especialização e suas famílias passaram a se amontoar nas grandes cidades, a burguesia, ansiosa em controlar os possíveis “desvios” da "turba”, começou a valorizar os estudos na linha de cientistas como Cesare Lombroso (1835-1909), que buscava estabelecer um padrão físico para o reconhecimento da criatura degenerada, criminosa. Todos aqueles que, por azar, caíssem nos limites de seus critérios, poderiam ser considerados inadequados para a convivência em sociedade e completamente desacreditados. O trancafiamento seria o destino mais provável.

Na mesma esteira das idéias de Lombroso, que procurava estabelecer as características físicas dos supostos criminosos para enclausurá-los, de modo que a sociedade não fosse vítima de suas “perversões”, o isolamento de indivíduos doentes ou “degenerados” era considerado plenamente legítimo e profilático na Alemanha e noutras partes do mundo da primeira metade do século XX. Entretanto, afastá-los das pessoas “normais” já não mais parecia suficiente. Passou-se a defender sua esterilização para que a disseminação de “deformações” e “anormalidades” fosse, definitivamente, eliminada.

Em 1919, foi fundada a Sociedade Alemã de Higiene Psíquica, e Alfred Grotjahn, deputado do PSD, defendeu publicamente a esterilização de alcoólatras, criminosos, epiléticos, doentes mentais e “defeituosos”. Anos depois (1928), Wilhelm Frick, deputado do NSDAP e futuro ministro do

\footnotetext{
${ }^{309}$ Belmonte. Opposição e Loucura. Crônica publicada na Folha da Noite (São Paulo) em 17/05/1933, p. 2.
} 
interior do Reich, exigiu a adoção da esterilização e a castração de criminosos sexuais e de homossexuais envolvidos nos delitos de sedução de menores, assim como estava definido no parágrafo 175 da Constituição de Weimar ${ }^{310}$. Na Saxônia, o Dr. Gerhard Boeter, simpatizante do Nazismo, defendeu a esterilização para cegos e surdos de nascença, idiotas, epiléticos, doentes mentais e mães geradoras de malformados.

De qualquer modo, a campanha de esterilização prosseguiu centrada nestes três pontos:

1) os doentes hereditários eram sustentados pela população sadia;

2) a reprodução dos inferiores intensificava a corrupção da raça;

3) o crescimento dos degenerados ameaçava o corpo social.

Essas teses eram difundidas em conferências, palestras, programas de rádio, curso para funcionários, enfermeiros e médicos. ${ }^{311}$

Alguns anos antes, na década de 10, defendiam-se publicamente algumas propostas para a eliminação de pessoas acometidas por determinados males. Em Die Frage der Vernichtung lebensunwerten Lebens (“A Questão do Extermínio das Vidas Indignas de Serem Vividas”, 1920), o jurista Karl Binding e o psiquiatra Alfred Hoche advertiam que o custo da manutenção dos doentes mentais em hospitais públicos era muito alto e propunham, portanto, que uma reunião de médicos e juristas aprovasse uma morte indolor para $\mathrm{eles}^{312}$. Em Menschliche Erblichkeitslehre und Rassenhygiene (“Higiene Racial e Hereditariedade Humana”, 1921):

(...) Os professores Dr. Erwin Baur , Dr. Eugen Fischer e Dr. Fritz Lenz sugeriram medidas radicais para o ‘saneamento da raça ariana’. Em Die Erlösung der Menschheit vom Elend (A Solução da Miséria para a Humanidade, 1922), Gerhard Hoffmann defendeu a eutanásia dos doentes incuráveis e dos idiotas; e o jurista Borchart encontrou fortes razões econômicas para justificar seu projeto de lei para matar todos eles. ${ }^{313}$

Parcelas não-desprezíveis de alemães terminaram por aderir a estas propostas de esterilização ou eliminação de doentes incuráveis. A fome e a desvalorização da vida, advindas da matança realizada durante a I Guerra, além da severa crise econômica que empurrou parte considerável dos

\footnotetext{
${ }^{310}$ Luiz Nazário. Idem, ibidem, p.33. In: Ernst Klee. "Euthanasie” im NS-Staat: Die "Vernichtung lebensunwerten Lebens”. Frankfurt, Fischer, 1991, pp. 29-30.

${ }^{311}$ Cf. Luiz Nazario, op. Cit., p. 31.

${ }^{312}$ Idem, ibidem, pp. 28-29.

${ }^{313}$ Idem, ibidem.
} 
germânicos para a miséria absoluta e a imensa dificuldade na obtenção de produtos básicos para a vida, inclusive de alimentos, embruteceram o caráter daquela gente, tornando estas idéias de alguma forma aceitáveis ${ }^{314}$. A questão era que, se não havia alimentos suficientes para todos, se eles eram muito custosos, que ficassem reservados para os "sadios”. O Estado alemão não deveria sacrificar financeiramente seu empobrecido povo cobrando-lhe caros impostos para o sustento e tratamento de loucos, pervertidos e malformados.

Os seres humanos tornavam-se, em larga medida, supérfluos, descartáveis ${ }^{315}$. Mas os doentes incuráveis, na sua condição de total incapacidade produtiva e de inadequação estética, tornavam-se ainda mais supérfluos e descartáveis.

Foi essa Alemanha que os Nazistas encontraram quando assumiram o poder em janeiro de 1933: idéias eugênicas e profiláticas disseminadas pela sociedade e difundidas com amplitude pelos próprios nazistas, dentre outros. Dessa forma, o caminho para o massacre dos indesejáveis já estava esboçado.

Belmonte lia alemão com bastante facilidade, uma vez que se aplicara, durante a adolescência, ao estudo deste idioma. Certamente, teve acesso a jornais alemães ou a informações fornecidas por agências internacionais de notícias, porque o fato de ele ter destacado e reiterado na crônica Opposição e Loucura os discordantes do Regime Nazista como loucos, degenerados ou criminosos $^{316}$, exemplos de excluídos por excelência daquela sociedade extremamente autoritária, foi de uma perspicácia muito grande. Se o artista estivesse menos informado do que ocorria na Alemanha, a referência taxativa feita pelo ministro bávaro sobre os "loucos” e os “criminosos” talvez tivesse passado em branco.

Ainda que a eugenia tenha se configurado numa verdadeira "obsessão científica" na Alemanha, ela também foi propalada em outros países pela Europa, nos Estados Unidos ${ }^{317}$ e nas Américas, inclusive no Brasil.

No Brasil dos anos 1910-30, a eugenia teve em Francisco José de Oliveira Vianna um dos seus grandes expoentes ${ }^{318}$. Em sua obra Populações Meridionais do Brasil (1920), este jurista e

\footnotetext{
${ }^{314}$ Idem, ibidem, p. 28.

${ }^{315}$ Cf. Hannah Arendt. Origens do Totalitarismo. São Paulo: Companhia das Letras, 1989, pp. 300-355 e pp. $512-531$.

316 Também denominados na mesma crônica por “dementes” e "tarados”, palavreado mais ao gosto dos eugenistas.

${ }^{317}$ Em verdade, os EUA foram pioneiros na formação de instituições eugênicas, fundadas nos primeiros anos do séc. XX (1905). Algumas destas instituições sobrevivem até hoje, porém, portam outros nomes que não eugenia, pois este estudo "científico" terminou estigmatizado após as brutalidades perpetradas pelo Nazismo. Segundo a historiadora Pietra Diwan, “...diferentemente dos Estados Unidos, a eugenia na Alemanha teve vida mais curta, ainda que mais intensa." Sabe-se que durante o Nacional-socialismo, a teoria eugênica foi empregada de modo extremado e inédito. Afinal, centenas de milhares de pessoas foram esterilizadas a força e mais de 6 milhões foram impiedosamente assassinadas.

Cf. Pietra Diwan. “Eugenia, a biologia como farsa”. In: História Viva. São Paulo: Duetto, volume 49, (11), 2007, pp. 0203. In: http://www2.uol.com.br/historiaviva/reportagens/eugenia_a_biologia_como_farsa.html
} 
sociólogo expõe uma visão extremamente pessimista do país, uma vez que ele é povoado por uma grande parcela de indivíduos “degenerados” e "inferiores”, porque mestiços com sangue negro e considerados, justamente por isso, uma "sub-raça”.

Autores como Ratzer, Gobineau, Lapouge, Ammon e Le Bon, entre outros, são as fontes teóricas de seus primeiros livros, dentre os quais Populações Meridionais. Aliados a seu racismo proeminente $^{319}$, Oliveira Vianna preconizava também a valorização do autoritarismo estatal e a centralização governamental. Não por acaso, este escritor seria, junto com Azevedo Amaral, um dos maiores ideólogos do Estado Novo ${ }^{320}$.

O médico Renato Kehl, eugenista de renome e colega de Oliveira Vianna no que tange à variedade de argumentos racistas, recebeu grande influência de instituições eugênicas alemãs. Ele defendia com ímpeto a desigualdade natural entre as raças, sendo a branca marcadamente superior às outras.

Em suas considerações, ele desaconselhava os casamentos com pessoas de classe inferior e as uniões de brancos com negros ou com mestiços das primeiras gerações, pois era quase certo que esses cônjuges gerariam indivíduos com fraquezas morais e, não raramente, com doenças mentais, debilidades ou deformações físicas. Os “cruzamentos” de brancos com negros eram, definitivamente, criticados e repudiados com dureza pelos eugenistas, dentre os quais se destacava Kehl.

Após uma leitura atenta de escritos em que o médico brasileiro expõe os principais pontos da sua concepção sobre eugenia ${ }^{321}$, a pesquisadora Marcia Yumi Takeuchi mostra que Renato Kehl, assim como muitos eugenistas alemães, defendia que:

\footnotetext{
318 Juntamente com Miguel Couto e Renato Kehl. Este último foi o fundador da Sociedade Eugênica de São Paulo (1918), da Liga Brasileira de Higiene Mental (1920) e da Comissão Central Brasileira de Eugenia (1930), tendo sido influenciado pela Comissão da Sociedade Alemã de Higiene Racial, com a qual se correspondia. Por meio da CCBE, Kehl se aproximou de Vianna, então consultor jurídico do governo provisório de Getúlio Vargas, e integrou, juntamente com ele, um grupo designado pelo recém-fundado Ministério do Trabalho para pensar os problemas da imigração no Brasil (isso em 1932). Os resultados dos trabalhos da Comissão de Imigração liderada por Oliveira Vianna contribuíram para a formulação da Lei de Restrição à Imigração, legalizada à época da Constituição de 1934, que dificultou imensamente a entrada de japoneses, judeus e negros no Brasil - classificados por grande parte dos membros da Comissão como inassimiláveis e racialmente inferiores.

Cf. Pietra Diwan, idem, pp. 06-07.

319 Oliveira Vianna reavaliou suas idéias racistas após 1930, mas sem modificá-las no essencial. Cf. Jarbas Medeiros. Ideologia Autoritária no Brasil. 1930-1945. Rio de Janeiro: Fundação Getúlio Vargas, 1978, p. 189. In: Maria Helena Capelato. Os Arautos do Liberalismo. Imprensa Paulista (1920-1945). São Paulo: Brasiliense, 1989, p. 82.

Cf. Ricardo Sequeira Bechelli, op. Cit.

Cf. também Danilo Zion Ferretti. A Construção da Paulistanidade. Identidade, Historiografia e Política em São Paulo (1856-1930). Tese de Doutorado, Departamento de História da Universidade de São Paulo. São Paulo: digitado, 2004, pp. 260-270.

${ }^{320}$ Cf. Maria Helena Capelato, op. Cit., p. 61 e 164.

321 Renato Kehl. Boletim de Eugenia. Ano I, Rio de Janeiro (1), Jan. 1929. E Por que sou eugenista: 20 anos de campanha eugênica (1917-1937). Rio de Janeiro: Francisco Alves, 1937. Cf. Marcia Yumi Takeuchi. O Perigo Amarelo. Imagens do Mito, Realidade do Preconceito (1920-1945). Dissertação de Mestrado em História Social apresentada à FFLCH/USP. São Paulo: digitado, 2004, pp. 17-18.
} 
(...) Deveriam procriar apenas aqueles que estavam aptos para dar nascimento a seres bem-dotados. Para tanto, eram recomendados exames pré-nupciais e a proibição dos casamentos de doentes e degenerados, devendo se recorrer até mesmo à esterilização. ${ }^{322}$

É indubitável que, na República Nova, a eugenia foi o sustentáculo teórico para a discriminadora Lei de Restrição à Imigração, colocada em vigor com a Constituição de 1934. Isso sugere que, encaradas à época como a solução do problema racial e daquele de heterogeneidade cultural, as teorias eugênicas tinham muito destaque, especialmente no governo de Getúlio Vargas ${ }^{323}$.

Percebe-se, portanto, que Belmonte capta magistralmente a disseminação do discurso eugênico pelo mundo, posicionando-o como um instrumento a serviço do autoritarismo e, consequentemente, relacionando-o com o desrespeito às normas democráticas. Insinuava-se, pelo lápis do escritor, um posicionamento progressista.

Entretanto, ainda que Belmonte percebesse a difusão da eugenia, ele jamais discorreu sobre a influência dela na cultura e no governo brasileiros, concentrando-se na sua propagação por outros países.

No final da crônica, o artista relembra seu leitor dos obstáculos à democracia no Brasil, induzindo-o a uma reflexão sobre a política brasileira recente - da Primeira República - e de sua atualidade. Novamente, as práticas políticas do Brasil parecem, em certo sentido, ombrear-se com as germânicas:

\begin{abstract}
Aliás, a these bávara não é nova. Géca Tatu, por estas bandas complicadas, nunca pensou de outro modo, pois sempre que se lhe pede um voto para as opposições, ele retruca com um sorriso simplório:

- Ché, moço! Eu votá contra o governo? Num vê!...Eu não sô loco! ${ }^{324}$
\end{abstract}

Este trecho acima remete-nos à eleição dos deputados para a Assembléia Nacional Constituinte, que ocorrera em 03/05/1933. Belmonte temia pela transparência do pleito, uma vez que

\footnotetext{
322 Cf. Marcia Yumi Takeuchi, op. Cit., p. 18.

${ }^{323}$ Sobre esse assunto, ver Maria Luiza Tucci Carneiro. O Anti-semitismo na Era Vargas: fantasmas de uma geração. $2^{\circ}$ ed. São Paulo: Brasiliense, 1995.

Na verdade, esse tema é polêmico. Vale lembrar também, com Lilia Schwarcz, que a ideologia governamental, sobretudo a partir da segunda metade dos anos 30, enfatizou um Brasil mestiço e até valorizou aspectos das tradições afrobrasileiras como positivamente constitutivos da nação. Houve, concomitantemente, a valorização do samba e da mestiçagem e uma tendência à discriminalização do Candomblé.

Lilia Moritz Schwarcz. "Nem preto nem branco, muito pelo contrário”, in: Lilia Moritz Schwarcz (Org.). Contrastes da intimidade contemporânea. São Paulo: Cia. das Letras, 1998 (História da vida privada no Brasil - 4).

${ }^{324}$ Belmonte. Opposição e Loucura. Crônica publicada na Folha da Noite (São Paulo) em 17/05/1933, p. 2.
} 
o governo getulista não se mostrava entusiasmado com ele, pois protelara as medidas cabíveis para a elaboração de uma Constituição por cerca de dois anos e meio. Além do mais, até então, as eleições brasileiras sempre ocorreram marcadas pela mais absoluta corrupção dos princípios democráticos; elas culminavam com a previsível vitória dos partidos republicanos regionais e do PR paulista, soberano no panorama político brasileiro anterior à década de 30.

O temor de que a eleição daquele ano fosse processada como no passado recente, em que a trapaça e a agressão física favoreciam o governo, estava evidente não apenas nas linhas do cronista como também no editorial do jornal Folha da Noite. Este denotava o receio de que, a partir de então, os candidatos considerados favoráveis à “dictadura” pudessem obter alguma vantagem de estruturas eleitorais tomadas como tradicionalmente viciadas:

Se alguém perpetrar um golpe de força ou de velhacaria, a reacção precisa ser immediata e efficiente. Por outras palavras: cada eleitor há de ser o fiscal da sua secção, para que o pleito se desenrole, desde o seu início até o seu termo, dentro das normas da mais rigorosa severidade e da mais perfeita decência (...). O falsificador e o capanga foram os instrumentos de todas as desgraças que infelicitaram São Paulo e o Brasil. Eram simples mandatários, que cumpriam ordens. Mas, se não existissem, isto é, se os potentados que queriam aterrorizar o eleitorado ou defraudar uma eleição não encontrassem agentes para os seus crimes, é perfeitamente certo de que não teria sido preciso fazer-se a Revolução de Outubro em protesto contra a deturpação da verdade eleitoral.

Qualquer que seja a sua cor política ou partidária, todos os paulistas hão de declarar guerra á violência e á fraude. Em nome da civilização de São Paulo. Em nome da felicidade do Brasil." ${ }^{325}$ [grifos nossos]

Não se tinha ainda conhecimento do resultado das eleições quando da publicação desta crônica de 17/05, pois as urnas eram apuradas aos poucos e a porcentagem dos votos seguia publicada diariamente no vespertino da Folha. E prosseguiu-se desta forma para além da terceira semana do mês, sabendo-se do resultado geral do pleito apenas nos últimos dias de maio.

Entretanto, a temida fraude eleitoral a favor do governo provisório não ocorreu, pelo menos não com amplitude. Hoje sabemos que o resultado da eleição para a Assembléia Nacional Constituinte apontou para uma vitória esmagadora das elites estaduais. Isso, evidentemente, representou e comprovou o seu domínio sobre o eleitorado, em especial o rural $^{326}$.

\footnotetext{
${ }^{325}$ Editorial: A Fraude a Violencia. Folha da Noite (São Paulo), 19/04/1933, p. 2. Hemeroteca AE/SP.

${ }^{326}$ Cf. Edgard Carone. A República Nova (1930-1937). 3 a edição. São Paulo: DIFEL, 1982, pp. 318-321.
} 
Em As novas barbas do Irineu, publicada a 26 de agosto de 1933, o escritor reafirma sua opinião de que o Nazi-fascismo parecia-lhe intolerante com as concepções divergentes. A história desta crônica desenrolou-se do seguinte modo: Belmonte conta a trajetória do exaltado exparlamentar brasileiro Irineu Machado, que toda a vez em que ia à Europa insiste em voltar com alguma novidade. Da primeira viagem, o político cortou sua imensa e imponente barba, causando à sua imagem um inegável prejuízo, pois, segundo assegura-nos o artista, "Irineu sem barbas era tão desnorteante como um gallo indio depennado; perdeu noventa por cento do prestígio que lhe dava o seu physico de patriarcha ou de thaumaturgo"327.

Mas a conseqüência da segunda ida ao exterior foi ainda mais desconfortável que a anterior, haja visto que o ex-tribuno voltou defendendo idéias fascistas. Nesse sentido, o escritor procurou evidenciar que o posicionamento de Irineu Machado era completamente contraditório; afinal, como podia ele apoiar os Fascismos se seu comportamento como parlamentar revelara um homem audacioso, impulsivo, afeito em colocar-se na oposição ao governo? Ora, Irineu Machado, estorvado político “do contra”, só poderia exercer seu cargo público em uma democracia, mas jamais em uma ditadura fascista ou nazista, onde a oposição é incansavelmente perseguida e silenciada:

(...) O sr. Irineu é, como se sabe, e como eu já disse, um espírito rebelde e insatisfeito. O ex-pelludo parlamentar não tem feito outra cousa, senão agitações na Câmara e nas praças públicas. É uma mania como qualquer outra mas, em ultima analyse, só praticavel nas democracias. Sob este regime, o sr. Irineu pôde, sempre o que quis, fazer flammular aos ventos das ruas, como um pendão de guerra, a sua drapejante barbaça, e descompôr os governos. E se, agora, não tem mais essas barbas flammulantes, deve ter ainda o seu vozeirão atroador, para derrubar governos na praça publica.

Ora, sob o regime fascista, Irineu será obrigado a emmudecer. E que será delle, no dia em que não puder falar? Irineu sem barbas é uma coisa que se admitte. Mas Irineu sem discursos seria uma auto-calamidade: o 'fogoso tribuno', obrigado a accumular dentro de si próprio todos os discursos que faria, se pudesse, ver-se-ia atacado de uma impressionante retenção de diathese verborrhagica, e acabaria explodindo como um barril de pólvora. ${ }^{328}$ [grifos nossos]

O inusitado e tragicômico fim de Irineu Machado proposto pelo cronista surge para corroborar com a observação de que a característica comportamental do político diferia completamente daquela

\footnotetext{
${ }^{327}$ Belmonte. As novas barbas do Irineu. Crônica publicada na Folha da Noite (São Paulo) em 26/08/1933, p. 2.

${ }^{328}$ Belmonte. As novas barbas do Irineu. Crônica publicada na Folha da Noite (São Paulo) em 26/08/1933, p. 2.
} 
exigida pelos Fascismos, a de obediência total e absoluta dos indivíduos ao partido único e a seu líder, o Führer ou o Duce.

Durante o discorrer da crônica, Belmonte se posiciona claramente contra a nova atitude do exparlamentar:

\begin{abstract}
Annuncia-se, agora que vae voltar. E, como não tinha mais barbas para cortar, o exsenador desfez-se de suas idéas liberaes e vem ahi, bravo e inoxeravel, para exigir que se implante o fascismo no Brasil.

Eu não acho graça nenhuma nessa nova pilhéria do ex-terrível tribuno de comícios. Se o ex-senador acha necessário trazer novidades da Europa, cada vez que volta do velho mundo, eu confesso que acho muito mais interessante o resultado de sua primeira viagem. Um rosto escanhoado, mesmo com rugas é sempre mais divertido do que uma dictadura. ${ }^{329}$ [grifos nossos]
\end{abstract}

O artista conclui seu escrito de modo completamente imprevisível, reafirmando sua oposição perante o Fascismo. O último parágrafo possui a sucinta argumentação que explica o porquê de uma diretriz política tão equivocada por parte de Machado: “Como se vê, o Sr. Irineu tirou as barbas do queixo, mas deixou-as crescer no cérebro.” ${ }^{330}$. Ou seja, a recente concepção fascista do político surge na crônica como conseqüência de uma anomalia no funcionamento orgânico, quase que como uma doença cerebral. Os pelos crescem no interior de sua cavidade craniana, comprometendo-lhe o raciocínio, de sorte que o Fascismo configura-se na ausência absoluta da razão.

A preocupação de Belmonte quanto à política não se restringiu apenas ao hitlerismo ou ao governo brasileiro. Internamente, outro grande inimigo do liberalismo ganhava destaque: “ $\mathrm{O}$ Integralismo, moldado sobre o fascismo, com adaptações nacionais, expande-se em nível nacional”331, angariando respeitabilidade e apoiadores a passos largos.

As semelhanças do Integralismo com o Fascismo, especialmente o italiano, são marcantes. Há em ambos a crítica ao liberalismo econômico, no sentido de que a reprodução de desigualdades sociais gritantes fomenta a adesão dos trabalhadores ao Comunismo, e há também o escamoteamento

\footnotetext{
${ }^{329}$ Idem, Ibidem.

${ }^{330}$ Idem, Ibidem.

331 Ver Marilena Chaúi.”Apontamentos para uma crítica da Ação Integralista Brasileira”. In: Marilena Chauí; Maria Sylvia Carvalho Franco. Ideologia e Mobilização Popular. São Paulo: CEDEC/Paz e Terra, 1978, p. 65. Já José Chasin não identifica o Integralismo ao Fascismo, tendo em vista as diferentes modalidades de Capitalismo que existiam no Brasil, na Itália e na Alemanha: Cf. José Chasin. O integralismo de Plínio Salgado: formas de regressividade no capitalismo hiper-tardio. São Paulo: Ciências Humanas [s/d].
} 
das lutas de classes, sendo estas diluídas na proposta do corporativismo, onde as palavras “categoria” ou “classe profissional” substituem o sentido político e dialético do conceito marxista “classe”. Outros aspectos fundamentais a esses movimentos políticos de extrema direita referem-se ao nacionalismo xenófobo, ao autoritarismo, ao estatismo e à conservação dos fundamentos da sociedade capitalista.

A AIB - Ação Integralista Brasileira -, fundada em 1932 por Plínio Salgado, assistiu a um crescimento impressionante no número de seus filiados em 1934. No começo desse ano, ela realizou sua primeira conferência na capital do Espírito Santo. Cerca de dois meses depois, sua milícia fez uma demonstração pública, marchando nas ruas da cidade do Rio de Janeiro, e no início do ano seguinte, três mil integralistas compareceram ao segundo congresso nacional, em Petrópolis. Segundo Robert Levine, no final de 1934 o Integralismo se tornara um movimento político considerável, com cerca de 180.000 membros $^{332}$. Na segunda metade daquele ano, tanto a ofensiva integralista quanto o movimento popular de oposição a ela (prelúdio da Aliança Nacional Libertadora) aumentaram muito. E, já em 1934-35, o Estado de São Paulo tinha o maior número de municípios integralistas, $173^{333}$.

A imprensa de São Paulo (os Diários da Noite e de São Paulo, A Gazeta e, sobretudo, $O$ Estado de São Paulo) dirigiu mitigadas críticas à Ação Integralista Brasileira, assim como ao Nazifascismo. Por outro lado, o Comunismo era freqüentemente estampado em seus editoriais como um grande perigo $^{334}$, conforme já observamos nas páginas iniciais desse capítulo.

Parte da intelectualidade se mostrou muito receptiva à AIB: Hélio Viana, historiador, Thiers Martins Moreira, do Ministério da Educação, e Gustavo Barroso, escritor anti-semita declarado, admitido na Academia Brasileira de Letras em 1932, filiaram-se ao movimento integralista. E outros, como o escritor Alceu de Amoroso Lima e o sociólogo Artur Neiva, sentiam simpatia pelos integralistas $^{335}$.

Alguns industriais de São Paulo, com receio da organização dos trabalhadores de esquerda, auxiliavam a AIB financeiramente. Outros eram abertamente favoráveis ao regime fascista italiano. O Conde Francisco Matarazzo, por exemplo, ofereceu um milhão de liras para o Movimento da Juventude Fascista e mais um milhão de liras para ajudar a política expansionista de Mussolini, que

\footnotetext{
${ }^{332}$ Ver Robert Levine, O Regime de Vargas (os anos críticos, 1934-1938). Rio de Janeiro: Nova Fronteira, 1980, p. 131147 passim.

${ }^{333}$ Ver Robert Levine, 1980, p.144.

${ }^{334}$ Ver Maria Helena Capelato; Maria Lígia Prado. O Bravo Matutino (Imprensa e ideologia no jornal "O Estado de São Paulo”). São Paulo: Alfa-Omega, 1980, p. 102 e pp. 105-107. Ver também Maria Helena Capelato, 1989, pp. 120-123.

${ }^{335}$ Ibidem, p. 140-141.
} 
invadia a Etiópia ${ }^{336}$. Rodolfo Crespi, por sua vez, foi agraciado pelo ditador italiano com a Ordem do Trabalho e, posteriormente, feito Comendador da Coroa da Itália ${ }^{337}$.

Havia muitas personalidades públicas que, embora não fossem associadas à AIB, apoiavam seus ideais. O chefe de polícia Filinto Müller demonstrava muita estima pelo Integralismo ${ }^{338}$. Nas Forças Armadas, o movimento conseguiu um número muito grande de admiradores, dentre os quais figuravam os Generais Meira de Vasconcelos, Pantaleão Pessoa e Newton Cavalcanti ${ }^{339}$. A simpatia pela AIB foi considerável, sobretudo na Marinha ${ }^{340}$. Já o General Góes Monteiro admirava o Fascismo italiano $^{341}$.

Lembremos também que, naqueles anos tumultuados, a classe profissional militar estava longe de prezar a democracia. Na primeira metade de 1934, as discussões da Assembléia Nacional Constituinte se desenrolaram concomitantes às ameaças golpistas de militares inimigos da reconstitucionalização do país, ameaças que prosseguiram mesmo depois de promulgada a carta, em 16 de julho.

Entre março e maio daquele ano, Góes Monteiro, aproveitando-se da grande visibilidade de seu cargo de general e do trabalho como ministro da Guerra ${ }^{342}$, além de contar com o apoio de colegas de farda, procurou manobrar os acontecimentos políticos para impor sua candidatura à presidência da República, e sem cercar suas intenções com a devida cautela. Entre rumores que circulavam nos bastidores da política ${ }^{343}$, dizia-se que Pedro Góes estava disposto até a dar um golpe para conquistar o cargo executivo do país ${ }^{344}$. A opinião pública e o próprio governo sabiam do profundo desprezo com que o general encarava o processo de legalização:

[Ele] foi mestre em manipular conspirações que pretendiam inviabilizar os trabalhos da Constituinte: incentivava-as ou as retardava, tirando o melhor proveito da situação.

\footnotetext{
${ }^{336}$ Ver Robert Levine, 1980, p. 144. Ver também Warren Dean. A Industrialização de São Paulo (1880-1945). São Paulo: DIFEL, [s/d]., p. 185-186.

${ }^{337}$ Ver Warren Dean, op. Cit., p.186.

338 Idem, p. 138-141.

${ }^{339}$ Idem, p. 139-140.

Ver também Marly de Almeida Gomes Vianna. “1934: A decadência da democracia liberal”. In: Revolucionários de 1935: sonho e realidade. São Paulo: Expressão Popular, 2007, p. 127.

${ }^{340}$ Ver Marilena Chaú́, 1978, p. 66.

${ }^{341}$ A simpatia de Góes Monteiro pelo Fascismo é destacada em uma crônica de 27/03/1934, A única differença, onde Belmonte comenta que "há também os cidadãos de idéias fascistas que não concordam com a intromissão feminina em assumptos que só dizem respeito ao homem. Entre estes últimos destaca-se o bravo general P. Góes”.

${ }^{342}$ Em que ele tomou posse em 18 de janeiro de 1934. Cf. Marly de Almeida Gomes Vianna, op. Cit., p.131.

343 Idem, pp. 130-134.

${ }^{344}$ É sabido que Góes Monteiro não chegou à presidência. Getúlio Vargas terminou por ser mais astuto e manobrou a política a seu favor.
} 
O ministro contava com a força dos militares que pretendiam, há tempos, tutelar o poder. ${ }^{345}$

Se antes os conspiradores configuravam-se principalmente nos tenentes, agora, aqueles que conspiravam tinham a patente de general. Com poucas exceções, a alta hierarquia do Exército aprovava o estrangulamento do regime democrático ${ }^{346}$.

Góes Monteiro era, com certa freqüência, personagem dos escritos de Belmonte, ainda que raramente o principal. As crônicas e alguns editoriais nos informam que o general, falastrão incorrigível, tinha fascinação em ser entrevistado pela imprensa, quando ele não perdia a oportunidade de expor suas opiniões políticas: Declarava-se favorável a um governo centralizado, forte, e discordava da autonomia dos estados inspirada em 1891 e considerava os regimes democráticos desorganizados e frágeis ${ }^{347}$. O general elogiava o Fascismo italiano e, como militar, declarava que as guerras e a belicosidade eram acontecimentos absolutamente naturais e aceitáveis no percurso da história humana.

Como não podia deixar de ser a um bom humorista-pacifista, o escritor não perdia a oportunidade de satirizar em suas crônicas as declarações de Góes Monteiro, valorizadoras do autoritarismo e da violência, ironizando-as e ridicularizando-as ${ }^{348}$. O ministro da Guerra era apresentado como o paradigma da brutalidade e, por vezes, como um indivíduo pouco avantajado intelectualmente.

As opiniões de Góes Monteiro figuravam com freqüência nas páginas dos jornais ${ }^{349}$ e Belmonte arrumou-lhe o tratamento zombeteiro de "meu colega de profissão". Mas o personagem político com presença mais constante nas crônicas era Getúlio Vargas, que, por deter o poder executivo nas mãos, representava para o artista o governo por excelência. Diferente do general, boquirroto impulsivo, Vargas procurava ser, na maior parte das vezes, discreto e imprevisível

\footnotetext{
${ }^{345}$ Marly de Almeida Gomes Vianna, op. Cit., p.131.

${ }^{346}$ Idem, ibidem.

${ }^{347}$ Editorial Contradições. Publicado na Folha da Noite (São Paulo) em 01/11/1933 na p. 02.

${ }^{348}$ Cf. Morrer por Morrer..., Crônica publicada na Folha da Noite (São Paulo) em 21/12/1933: “Creio que, mesmo no caso de explodir uma bagunça épica que exterminasse tudo, os proprios esqueletos se levantariam do fundo das covas para brigar. Isso, aliás, não é nenhuma novidade, embora pareça absurdo. O general P. Góes, numa de suas abundantes entrevistas, teve a gentileza de contar-nos que, há muitos millenios, os espíritos, chefiados por Lusbel, se revoltaram contra Deus, num charivari tremendo que encheu de tremores as tranquillas regiões siderais.” Ou seja, conforme o pronunciamento de Góes Monteiro, se até os anjos brigam, é mais do que natural e esperado que os homens também entrem em conflito. Assim o general justifica e defende as guerras.

349 "Há poucos dias, concedendo mais uma de suas exuberantes entrevistas, o bravo general P. Góes affirmou que o Brasil 'precisa ser disciplinado, por bem ou por mal.”' [grifos nossos]. Cf. Belmonte. “Disciplina Partidária”. Crônica publicada na Folha da Noite (São Paulo) em 07/03/1934, p. 2.
} 
(segundo o escritor). Esta característica do presidente da República era apontada nas crônicas e charges do humorista paulistano. Por isso, Getúlio ganhou dele o apelido de “despistador”, aquele que evita deixar “às claras” suas concepções e posicionamentos; é, também, aquele que tem tendência a enganar.

Em uma excelente crônica publicada a 12 de abril do ano seguinte, Belmonte critica o Nazifascismo e, ao mesmo tempo, exprime idéias negativas com relação a Getúlio Vargas (que buscava ser reeleito) e ao general Góes Monteiro, que elogiava publicamente o regime político de Mussolini. Belmonte discorre sobre a história de um homem que se identifica como seu assíduo leitor, e vai à redação do jornal para encontrá-lo pessoalmente. Então, ele enceta uma conversa com seu escritor preferido, colocando idéias ríspidas sobre os principais líderes do governo, ligando-os entre si como se fossem quase que a mesma pessoa, e relacionando-os ainda com certas atitudes autoritárias, sugerindo, assim, semelhanças entre eles e a ausência de democracia que imperava no regime fascista italiano.

O leitor opositor ao Fascismo é um senhor de idade avançada. Esta característica é apreendida por meio da sua saudação marcadamente formal e respeitosa - além de alongada, sendo que a modernidade, pelo contrário, clama pela agilidade e rapidez - e porque ele próprio afirma ter mais de cinqüenta anos de idade. Nesse sentido, a crônica liga a vivência longeva, o "velho”, ao respeito à democracia, ao passo que os "novos” são acusados de copiadores de estrangeirismos e, dentre estes, há a perigosa simpatia por “governos fortes” ou ditatoriais - de inspiração fascista.

Antes de tudo, cordeaes saudações.

- Obrigado [Belmonte].

- Desejo que a minha presença venha encontral-o no goso da mais perfeita saúde, em companhia de todos os que lhe são caros.

- ?! [Belmonte]

- Não se espante com esse exordio epistolar. É uma questão de hábito, ou melhor, uma questão de methodo que eu venho seguindo há cincoenta annos. Não é dessa forma que eu venho me dirigindo ao senhor todas as vezes que lhe escrevo? ${ }^{350}$

Os jovens, nas palavras do interlocutor de Belmonte, configuram-se como imitadores irrefletidos e inconseqüentes. Acompanhemos o antepenúltimo parágrafo da crônica:

${ }^{350}$ Belmonte. O 'assíduo leitor’. Crônica publicada na Folha da Noite (São Paulo) em 12/04/1934, p. 2. 
- E diga a esses mocinhos que andam na rua sem chapéo, que isso é muito feio. Vê-se que elles procuram imitar alguns rapazolas americanos - o que é uma prova de ausência de personalidade, de subserviência cabocla, de macaquice tropical. É por essas e outras que nós seremos sempre uma droga geographica: uns imitam ideologias políticas; outros imitam costumes inexplicáveis. Aquelles desejam um governo forte, estes querem andar sem chapéo. ${ }^{351}$

A mensagem transmitida por este último trecho transcrito assegura que "governos fortes” ou “dictaduras” são importações artificiais, exógenas à constituição histórica do povo brasileiro que, por natureza, seria mais propenso a prezar a democracia. Ora, em um período em que "as tradições do povo” e o nacionalismo eram altamente valorizados ${ }^{352}$, nada mais desabonador para os fascistas nativos do que considerar seu ideário completamente alheio aos costumes brasileiros. Ainda mais no caso dos camisas-verdes, profundamente nacionalistas.

Na polarização feita pelo artista entre o “velho” e o "novo”, é inevitável a associação dos primeiros como defensores da democracia. Já os “novos” se referem não apenas aos jovens brasileiros admiradores dos Fascismos e integralistas, como também aos políticos de parte da antiga Aliança Liberal que se apoderaram do exercício do poder ${ }^{353}$. Seus detratores, dentre os quais o próprio Belmonte, afirmavam que eles protelaram demasiadamente o retorno a um regime constitucional e, além do mais, naqueles idos de 1934, desejavam a permanência de Getúlio Vargas no cargo máximo do país.

Ou seja, o Presidente e seus companheiros estavam sendo acusados de antidemocráticos porque visavam sua perpetuação no poder sem efetivarem uma consulta aos cidadãos, de sorte que o político gaúcho é apresentado pela pena do escritor como mais autoritário que qualquer déspota, pois, perto dele, até as orientações contidas na obra de Maquiavel parecem singelas:

- (...) Sendo um assíduo leitor do seu conceituado vespertino, baluarte imperterrito das aspirações populares, peço-lhe agasalho para o meu mais veemente protesto contra a candidatura Getúlio Vargas.

\footnotetext{
${ }^{351}$ Idem, Ibidem.

352 “Na luta política da década de 30, o argumento das 'idéias importadas, inadaptáveis à realidade brasileira’ foi utilizado como arma ideológica para desqualificar e enfraquecer o inimigo”. Cf. Maria Helena Capelato, 1989 , p. 178.

${ }^{353}$ Dentre estes há militares reformistas e membros de uma nova geração oligárquica, em sua maior parte, exógena aos estados de Minas Gerais e São Paulo: Flores da Cunha, Getúlio Vargas, José Américo, Oswaldo Aranha, Virgílio de Mello Franco e outros. Estes se ombreiam com os chamados Tenentes, como Juarez Távora, João Alberto, Juracy Magalhães e outros. Cf. Edgard Carone. A República Nova (1930-1937). $3^{a}$ edição. São Paulo: DIFEL, 1982, pp. 387388.

Segundo o mesmo autor, os Tenentes/Interventores que permaneceram em destaque na política após 1933/34 foram aqueles que se acomodaram com as oligarquias de seus respectivos estados. Cf. op. Cit., pp. 391-393.
} 
- Hein?! [Belmonte]

- Sim senhor. Insurjo-me, desassombradamente, de viseira erguida, contra a perpetuação no poder desse homem terrível, desse usurpador faminto diante do qual Macchiavel é pinto!

- Bonito verso! [B.]

- Verso uma óva! Eu não vim aqui para fazer versos! Protesto contra a candidatura do Getúlio e protesto também, energicamente, contra a candidatura do Gegê!”354

Em verdade, são usadas as mesmas iniciais para nomear dois homens públicos diferentes: Getúlio Vargas e General Góes Monteiro. Este último acompanhava atento e ansiosamente o desenrolar da sucessão do cargo executivo, seduzido pela possibilidade de, eventualmente, se sentar na cadeira presidencial. Ambos os “Gegês” primavam pela característica autoritária inerente, cada um ao seu modo. O primeiro é mais astuto que os déspotas para os quais Maquiavel dedicou suas linhas e, por isso, tem grandes chances de permanecer na Presidência da República. Góes Monteiro, por sua vez, é colocado como adepto do Fascismo, e é exatamente nesta parte que se inicia a crítica mais veemente ao regime de Mussolini. A descrição dos agressivos métodos empregados por ele para manter a população submissa tem por objetivo o desabono do Fascismo perante os leitores:

- Mas o Gegê é o Getúlio mesmo... [Belmonte]

- Foi. Hoje não é mais. G.G. é o General Góes. Este também não serve.

- Mas é um homem sincero, patriota... [B.]

- Mas não póde. Como poderia um inimigo da democracia ser chefe de uma república democrática?

- Mas a república poderia ser fascista... [B.]

- Com que roupa? Onde é que está o pessoal para obedecer? Diga!

- Nós todos... [B.]

- Ainda uma vez permita que lhe diga: uma ova! Nós obedeceremos uma ova!

- Mas haverá manganello, óleo de ricino... [B.]

- Não adianta. O Brasil é muito grande: não há purgante que chegue.

- Mas há metralhadoras, canhões... [B.]

- Então seria uma República Policial. Viraria governo-Bernardes...

- Qual! Com o tempo... [B.]

- Mas com o tempo não haveria mais gente no Brasil. Estaria tudo nas cadeias, na Ilha dos Porcos, na Clevelandia, em Portugal, na Argentina, no Uruguay, no Paraguay... O governo ficaria no Brasil e os governados ficariam no estrangeiro. Eu, pelo menos, não vou nisso!

${ }^{354}$ Idem, Ibidem. 
O estranho cidadão levantou-se, deu um murro na mesa e berrou:

- Não vou nisso!”355 [grifos nossos]

Ao exprimir suas idéias, especialmente através de seu “assíduo leitor”, Belmonte aponta a incompatibilidade existente entre República Democrática e Fascismo. Ao instigar o diálogo com seu leitor-admirador, o ideário político dileto de Góes Monteiro surge marcadamente violento, inimigo das diferenças e intolerante. Percebe-se que o tom aparentemente conciliador do escritor frente à posição política do general é, sem dúvida alguma, falso, e é empregado no sentido de explicá-la didaticamente aos leitores, revelando-lhes alguns dos seus aspectos brutais.

A relação que o artista fez entre Getúlio Vargas, Góes Monteiro e o pensamento antidemocrático estava na ordem do dia. Ambos vangloriavam publicamente o fascismo alemão e, principalmente, o italiano.

Lembremos que, no início dos anos trinta, o general aconselhava os tenentes a amoldar seu pensamento político "num fascismo nacionalista”356. E Getúlio Vargas, num discurso de 1929, afirmara: “...minha diretiva no governo do Rio Grande [...] se assemelha ao direito corporativo, ou organização das classes promovidas pelo fascismo, no período de renovação criadora que a Itália atravessa." 357 Em setembro de 1933, confirmando seu desprezo pelo regime democrático e legal, assim discursara na Paraíba:

(...) Representa fato incontroverso - e os constituintes terão de levá-lo em conta - a decadência da democracia liberal e individualista e a preponderância dos governos de autoridade, em conseqüência do natural alargamento do poder de intervenção do Estado, imposto pela necessidade de atender a maior soma de interesses coletivos... ${ }^{358}$

Surpreende ainda o quão Belmonte estava bem informado sobre os métodos repressivos empregados pelo Fascismo na Itália. Muito provavelmente, o cronista informava-se através de correspondentes europeus (agências estrangeiras de notícia); o impressionante conhecimento do artista acerca dos métodos de repressão e exclusão do governo nazista foi também observado em uma crônica anterior, Opposição e Loucura. O mais provável é que alguns rumores sobre a violência estatal dos regimes fascistas circulavam pela imprensa brasileira. Logo, se a maior parte dos

\footnotetext{
${ }^{355}$ Idem, Ibidem.

${ }^{356}$ Cf. Boris Fausto. A Revolução de 30 (historiografia e história). São Paulo: Brasiliense, 1976, pp. 110-111.

${ }^{357}$ Diário Nacional, 11/08/1929. Cf. Boris Fausto, op. Cit., p. 110.

${ }^{358}$ Idem, ibidem.
} 
editorialistas e jornalistas brasileiros poupou a imagem do Nazi-fascismo, certamente isso não ocorreu por total desconhecimento do que se passava no interior das fronteiras italianas ou alemãs. 


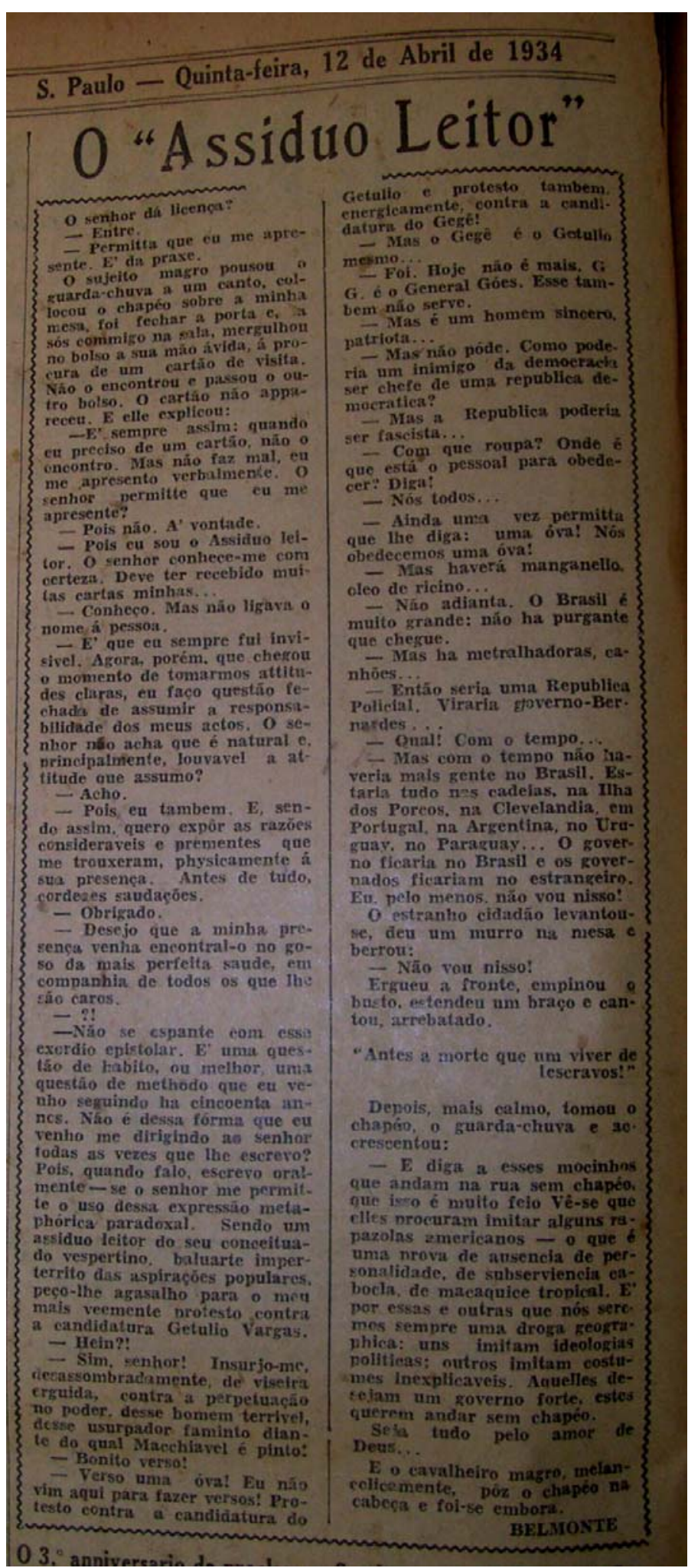

Fig. 13. O “Assiduo Leitor”. BELMONTE.

Folha da Noite (São Paulo), 12/04/1934, p. 2.

Hemeroteca do Arquivo do Estado de São Paulo - AE/SP. 
Em uma outra crônica, Um que virou, de 26/09/33, que também gira em torno de um diálogo do artista com um leitor, encontramos toda a sorte de palavras de repúdio direcionadas ao Fascismo; governo tirânico, arbitrário e monstruoso, entre outras. Este ideário político surge como uma aberração, gerado por um período histórico profundamente conturbado, incomum, virado do avesso:

- O senhor então, é contra o fascismo? [Belmonte]

- Oh, não! Pelo amor de Deus! Eu fui anti-fascista. Combati esta doutrina com todas as forças intellectuaes que tenho. O regime de arbítrio, o governo tyrannico, a concepção asphyxiante do Estado forte contra os sagrados interesses e direitos individuaes, tudo isso arrepiava a minha fina sensibilidade liberal. O fascismo era, para mim, a monstruosidade social erigida em dogma, o producto teratogenico de uma éra caótica geradora de toda espécie de aberrações sociaes. ${ }^{359}$ [grifos nossos]

Esta crônica liquida o Fascismo quase que por completo. A única coisa que dele se aproveita, segundo o leitor, é o cumprimento, pois não despenteia o cabelo dos homens, uma vez que não há necessidade de se tirar o chapéu para fazer a saudação:

- Oh! senhor! Estou lhe dizendo que fui contra o fascismo, mas continuo sendo antifascista.

- Ahn!... [Belmonte]

- O que acontece é que, agora, mas somente agora, eu cheguei a reconhecer que o fascismo, com todo o seu cortejo de aberrações teratogenicas...

- Bonito capítulo! [B.]

- ... ainda possue coisas louvaveis.

- Quer dizer que o senhor acceita o fascismo em parte. [B.]

- Exactamente. Mas o que eu acceito não é propriamente a parte doutrinaria. Essa, eu continuo a considerar uma pshychose social. O que eu acceito é a sua manifestação exterior, o seu ritual - se assim me posso exprimir.

- Póde sim. [B.]

- Em suma: o que me seduz no Fascismo é apenas a saudação.

- (...) E sabe por que sou adepto do cumprimento romano? Por uma razão muito simples: essa história da gente ser obrigada, na rua, no cinema, no bonde, a tirar o chapéo da cabeça para cumprimentar os conhecidos e, principalmente, as damas, é

${ }^{359}$ Belmonte. Um que virou. Crônica publicada na Folha da Noite (São Paulo) em 26/09/1933, p. 2. 
uma verdadeira estopada! Desmancha o penteado, amarrota a manga do paletó, deforma o chapéo...

- Lá isso é verdade. [B]

- Ora, desde que não se mexa mais no chapéo, e cumprimente-se os amigos com uma commoda e elegante saudação romana, o nosso penteado continuará incolume e o nosso chapéo durará mais alguns mezes. O senhor não acha?

- Acho.

- Então, meu caro senhor: viva o fascismo.

- O elegante cavalheiro ergueu o braço, exclamou um 'alalá' festivo e foi-se embora.”360 [grifos nossos]

É risível pensar em uma proposta política que possui apenas um aspecto bom: não despentear o cabelo. As ideologias políticas se voltam, impreterivelmente, para a organização e a condução das sociedades; mas, no caso da proposta deslocada do interlocutor de Belmonte, o não-despentear o cabelo é o único aproveitamento possível do Fascismo; todo o restante desse regime político extremamente autoritário deve ser banido e execrado, conforme atestam as duras palavras endereçadas a ele na crônica.

Observemos que, assim como na crônica As novas barbas do Irineu, o Fascismo é apresentado como uma doença. Trata-se de uma aberração ou anomalia. Ele é comparado pelo cavalheiro que dialoga com o escritor com a psicose, e recebe a definição de "aberração monstruosa”, com a qual Belmonte concorda inteiramente ao expressar as palavras “bonito capítulo!”, na sexta linha da última transcrição.

É interessante captar também o pensamento pequeno-burguês do interlocutor de Belmonte, admirador do cumprimento fascista. Este figurava-lhe como interessante porque não desarrumava o visual e conservava por mais tempo o bom estado do chapéu. Os leitores do artista, em geral pertencentes às camadas intermediárias da população, devem ter se divertido e, ao mesmo tempo, se identificado com a economia proposta pelo esperto homem, embora isso não signifique a identificação com o Fascismo. Em um período como aquele, em que ocorria o desdobramento da crise de 1929 e a carestia grassava, a possibilidade de poupar dinheiro com alguns artigos da indumentária masculina certamente era bem-vinda.

Se observarmos a estatística do custo de vida entre 1914-1938 ${ }^{361}$, veremos que as cifras cresciam quase que progressivamente, e alcançaram seu pico na segunda metade da década de 1930.

\footnotetext{
${ }^{360}$ Idem, ibidem.

${ }^{361}$ Cf. Roberto Cochrane Simonsen. Evolução Industrial do Brasil e outros Estudos. São Paulo: Editora Nacional/Editora da USP, 1973, pp. 26-28.
} 
Entretanto, se fixarmos como modelo de comparação os anos de 1910, o custo de vida manteve-se um tanto elevado na primeira metade da década de 1930, quase duas vezes mais alto do que naqueles, ainda que ele fosse um pouco menor do que na segunda metade dos anos 20:

\begin{tabular}{|c|c|}
\hline $\mathrm{Ano}^{362}$ & Custo de vida \\
\hline 1914 & 100 \\
\hline 1915 & 108,5 \\
\hline 1916 & 116,5 \\
\hline 1917 & 128,3 \\
\hline 1918 & 144,1 \\
\hline 1919 & 148,8 \\
\hline 1920 & 163,8 \\
\hline 1921 & 167,9 \\
\hline 1922 & 184 \\
\hline 1923 & 202,8 \\
\hline 1924 & 236,6 \\
\hline 1925 & 252,8 \\
\hline 1926 & 260 \\
\hline 1927 & 267,4 \\
\hline 1928 & 263 \\
\hline 1929 & 261 \\
\hline 1930 & 237,3 \\
\hline 1931 & 228,8 \\
\hline 1932 & 229,5 \\
\hline 1933 & 227,6 \\
\hline 1934 & 245,6 \\
\hline 1935 & 256 \\
\hline 1936 & 291 \\
\hline 1937 & 312 \\
\hline 1938 & 318 \\
\hline
\end{tabular}

362 Tabela adaptada. 
As camadas intermediárias urbanas, por se posicionarem materialmente entre as classes trabalhadoras e as privilegiadas, devem ter sido pressionadas pelo custo de vida nos anos 30. Para parte dessas classes médias (como a baixa classe média ${ }^{363}$ ), que tinha seu padrão de vida mais próximo dos trabalhadores do que dos grandes proprietários, a alimentação, o aluguel e o vestuário pesavam-lhe financeiramente todo mês.

Não temos conhecimento dos números referentes ao nível de vida das classes médias, mas, no caso das famílias obreiras, por exemplo, o inventário do "guarda-roupa” dos operários indicava que, em São Paulo, mais de 1/3 dos homens pesquisados possuía apenas um paletó e 27,7\% somente uma calça. Metade dos homens da amostra possuía um par de sapatos, sendo que a freqüência das demais peças era bastante baixa, com exceção da camisa ${ }^{364}$.

Ainda na crônica Um que virou, o discurso do leitor de Belmonte sublinha que o Fascismo configura-se como o extremo oposto da Democracia Formal e do Liberalismo. Temos, portanto, a reiteração desta idéia, visto que o escritor já a havia colocado em várias crônicas publicadas anteriormente.

- Não sei se me faria compreender se dissesse que estou a procura de uma formula que concilie, dentro do meu espírito, essas duas doutrinas antagônicas: fascismo e liberalismo, governo de Estado forte e governo do povo pelo povo. O senhor acha possível?

- Acho. Tenho visto consórcios mais disparatados... [Belmonte]

- Eu queria adoptar um fascismo-liberal, uma dictadura-democrática, um Estado forte, mas que não fosse tão forte assim, uma tyrannia com parlamentos...

- Valha-nos Deus! ${ }^{365}$ [B.] [grifos nossos]

Palavras completamente antagônicas e ligadas entre si por um hífen, tem, consequentemente, seu contraste intensificado. E a súplica a Deus efetivada pelo cronista-humorista, espantado, mostra que ele nunca havia escutado disparates tão fenomenais. Estes superaram definitivamente todo o seu vasto repertório de absurdos.

\footnotetext{
${ }^{363}$ Cf. Décio Saes. Classe Média e Sistema Político no Brasil. São Paulo: T. A . Queiroz, 1984.

${ }^{364}$ Cf. Zélia Lopes da Silva. A Domesticação dos Trabalhadores nos anos 30. São Paulo: Marco Zero/CNPq, 1990 , p. 41.

365 Belmonte. Um que virou. Crônica publicada na Folha da Noite (São Paulo) em 26/09/1933, p. 2.
} 


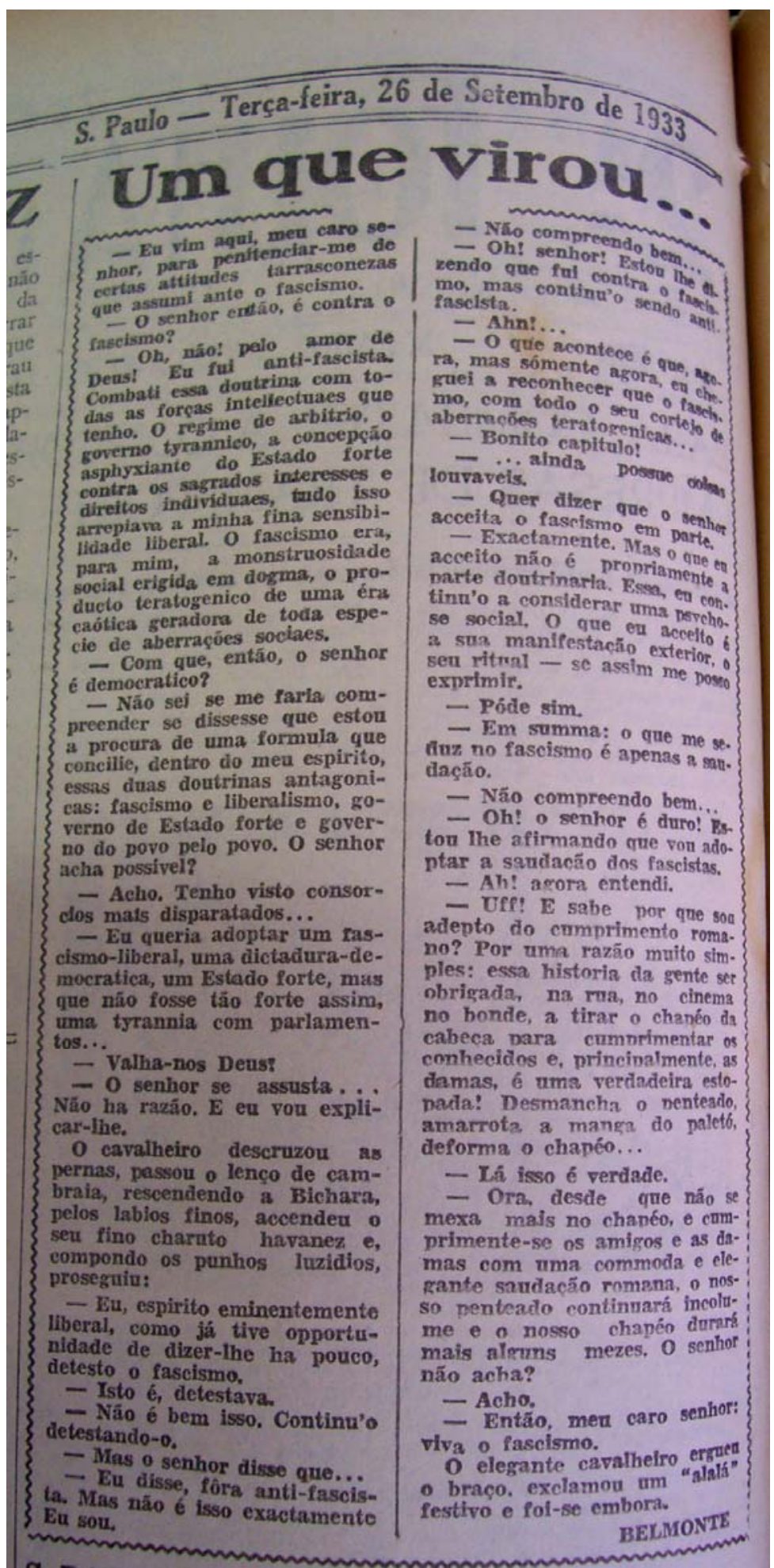

Fig. 14. Um que virou... BELMONTE.

Folha da Noite (São Paulo), 26/09/1933, p. 2.

Hemeroteca do Arquivo do Estado de São Paulo - AE/SP. 
Mas não era “apenas” o aspecto antidemocrático do Fascismo que incomodava Belmonte. A sua indubitável pretensão imperialista, caracterizada especialmente pelo nacionalismo exacerbado e pelo militarismo marcante, também o inquietava. E, à época, o sentimento de desamparo de muitos homens comuns levou-os a cortejarem o Nazi-fascismo, que surgia como uma nova panacéia por se contrapor ao Liberalismo e à Democracia, ineficientes no combate da crise econômica. Segundo o artista, parecia-lhe quase certo que o incentivo fascista à investida por territórios alheios iria atirar a população européia em uma nova catástrofe bélica, cujas conseqüências destrutivas seriam, provavelmente, grandes, ainda que imprevisíveis em sua intensidade.

O 'New York Times', num dos seus últimos números aqui chegados, publica um curioso artigo sobre o movimento fascista na Europa. Vê-se, por essa resenha, que a idéia do 'Estado forte' está empolgando o velho continente de uma forma verdadeiramente epidêmica.

Ninguém ignora o que é o fascismo na Itália e na Allemanha, pois nesses países, elle tomou conta do poder e não admitte que o desconheçam.

Mas em outros países ele existe e marcha. E é natural que assim seja, porque as condições especialíssimas em que se encontra a Europa, depois da grande guerra, favorecem movimentos nacionalistas desse gênero. ${ }^{366}$ [grifos nossos]

E após discorrer sobre o desenvolvimento dos movimentos fascistas, que surgiam em vários países da Europa, o artista arremata: “Como se vê, a coisa promette. Como quasi toda essa gente é super-nacionalista, é fácil prever o fim de tudo isso: um 'sururu' geral e completo.” ${ }^{367}$ Ou seja, o fim natural e lógico do Fascismo é a guerra. Seu ideário se espalha pela Europa com a rapidez de uma epidemia. Este regime político é novamente relacionado com um mal, equiparado a uma doença.

O Nazi-fascismo é apresentado em estreita proximidade com o belicismo e o imperialismo em muitas outras crônicas.

Enquanto o artista era corrosivamente crítico com relação ao Nazi-fascismo, se nos detivermos no sistema soviético, chamado à época de Comunismo, a crítica belmonteana é bem mais branda. Se entre 1932 e 1935 encontramos vários escritos cujo objetivo principal era denegrir a imagem dos regimes políticos de extrema-direita, quanto às esquerdas, há um silêncio quase que total por parte do autor. Era como se o Socialismo e o Comunismo não lhe figurassem grandemente

\footnotetext{
${ }^{366}$ Belmonte. O Fascismo na Europa. Crônica publicada na Folha da Noite (São Paulo) em 26/09/1933, p. 2.

${ }^{367}$ Idem, ibidem.
} 
ameaçadores, diferentemente da posição da maior parte dos jornalistas e da imprensa à época, que repudiavam a vermelhidão quase monocromática de algumas bandeiras.

De todas as crônicas escritas neste período, encontramos apenas duas que têm como meta principal a crítica à União Soviética ou a alguma vertente de esquerda. Em Esquerda e Direita, publicada a 27/12/1933, Belmonte conta que um governo de esquerda (socialista) instituiu nos últimos anos na Espanha um Estado autoritário, que causou 180 incêndios de templos e conventos, 638 feridos e 335 mortos, de sorte que, nas recentes eleições para deputados, a direita ganhou mais cadeiras do que a esquerda, mesmo esta tendo o governo em suas mãos. Entretanto, permanece nas entrelinhas a sugestão de que, se a oposição pôde ganhar a eleição, a esquerda espanhola não se mostrava tão autoritária quanto os fascismos. Na crônica Opposição e Loucura, por exemplo, o ministro bávaro simplesmente descartou o reconhecimento de outros partidos e políticos com concepções divergentes daquelas do governo.

Em outra crônica ${ }^{368}$, há a informação de que a Rússia mergulhou no mais absoluto mistério após a revolução. Logo, por causa disso, essa região se tornou um dos poucos locais do mundo que mantinha uma aura de encantamento. Mas, ao relatar uma notícia sobre a URSS que colhera em uma agência internacional, o artista conta, até então um tanto incrédulo, o caso de um jovem russo de 16 anos que sobrevoou parte de seu país numa velocidade de 11.000 quilômetros por hora, pilotando um avião sem motor. Porém, assim que termina de relatar essa história estranha, o artista volta atrás em sua incredulidade e afirma, veemente, que acredita nela: "Juro que acredito. Uma vez eu disse que não acreditava na efficacia do plano quinquennal e um 'amigo da Russia' quase me demoliu a bengaladas. Desde esse dia dramático eu acredito em tudo o que quizerem...”369

Esta crônica sugere que os comunistas não toleram opiniões divergentes daquelas adotadas por eles, e compactuam, por isso, com um pensamento autoritário. E ao relatar casos muito pouco críveis sob o ponto de vista da razão, de cientistas que dão visão aos cegos e de outros que ressuscitam os mortos, fazendo uma hilária paródia com os milagres bíblicos ( ${ }^{\circ}$ parágrafo), Belmonte aponta que o Comunismo se sustenta na mentira, assim como os fascismos europeus. De qualquer modo, é um pouco precipitado chegar a uma conclusão sobre a opinião de Belmonte acerca do Comunismo, uma vez que, como críticas direcionadas às esquerdas, estas crônicas permanecem isoladas na totalidade da obra de 1932-35.

Por outro lado, em uma crônica nomeada Multiplique-mo-nos..., no quinto parágrafo, ao comparar as condições de vida das crianças brasileiras com as que viviam na União Soviética, o artista considera que as suas pequenas conterrâneas se encontram em indubitável desvantagem. O

\footnotetext{
${ }^{368}$ Belmonte. 11.000 Ks. por hora! Crônica publicada na Folha da Noite (São Paulo) em 05/07/1934, p. 2.

${ }^{369}$ Idem, ibidem.
} 
assunto em questão foi desencadeado por causa da herança devida aos órfãos menores de idade, em grande parte apropriada pelas várias instâncias do governo brasileiro. Dessa forma, o modesto dinheiro que por direito deveria pertencer à criança ficava reduzido a um valor irrisório. Belmonte começa suas linhas comentando o melancólico caso de uma garota que perdera o pai recentemente. Acompanhemos o desenrolar da crônica:

A menina foi receber a herança. Dez contos, afinal de contas, se não dão para sumptuosidades deliciosas, servem todavia para um principio de educação. A menina, pois foi receber os cobres mas, em lugar dos dez, recebeu uma miséria porque o Estado, a Justiça e outras complicações officiaes, fizeram sociedade com ella e quasi a deixaram no 'ora veja'. Convencionou-se, nesses últimos tempos, que a herança é um roubo feito á collectividade. Na Rússia, pelo menos, é assim. Mas como aqui não é Rússia por emquanto, o Estado não empolga todo o 'arame' do espolio, mas, por meio de taxas, impostos, custas, emolumentos e outras coisas exquisitas, vae entrando na sociedade e levando um tremendo naco do bolo, deixando o herdeiro com cara de quem não comeu nem gostou. ${ }^{370}$

O artista prossegue, efetuando uma crítica à avidez tributária do governo brasileiro e, concomitantemente, um reconhecimento bastante positivo do caso da URSS:

Ora, que a Rússia empolgue, integralmente, os cobres dos herdeiros, admitte-se, e até se applaude, porque a Rússia dá ás crianças tudo quanto ella precisa para viver, desde a alimentação até a educação. Aqui, porém, o caso é exactamente o antípoda...”371 [grifos nossos]

Entretanto, sabedor do risco em se posicionar como admirador de alguns dos aspectos do Comunismo, nas últimas linhas, o artista termina por desacreditar o seu elogio à URSS quando afirma que, naquele dia, nada de coerente ou aproveitável conseguira escrever:

E é numa terra destas [Brasil] que se fala em lei contra o celibato!

“Crescei e multiplicai-vos...”

\footnotetext{
${ }^{370}$ Belmonte. Multiplique-mo-nos... Crônica publicada na Folha da Noite (São Paulo) em 02/06/1933, p. 2.

${ }^{371}$ Idem, ibidem.
} 
E deixemos os "multiplicados" ao léo da vida e á mercê do sonho, sem roupas e sem escolas, sem hygiene e sem hospitaes, sem educação e sem futuro (...).

Eu acho que tudo isso está errado. Mas, evidentemente, eu sou maluco e só digo disparates. Façam de conta, pois, que eu não disse nada. Esta chronica não vale. ${ }^{372}$ [grifos nossos]

Na verdade, jamais saberemos com exatidão se este final foi elaborado pelo escritor precavido quando da criação da crônica, ou se a censura, ao ler uma primeira versão dela, pressionou-o para a efetivação de algumas mudanças.

De qualquer modo, é notável que em um período no qual, via de regra, o Comunismo era abominado pelos liberais e a grande imprensa dispensava tão pouca boa vontade para com ele, Belmonte tenha tido a coragem de apontar certos aspectos benéficos da sociedade soviética, a ponto de escrever que ela merecia aplausos por alimentar e educar todas as suas crianças. Isso revela que o cronista reconhecia alguns dos limites da sociedade capitalista, como a falta de perspectiva gerada pela pobreza aguda.

Ainda que afeito à democracia e ao liberalismo e entendendo-os como propulsores da liberdade individual, Belmonte não deixa passar em branco um problema central do capitalismo e que, por sua vez, restringe radicalmente a liberdade e a felicidade de muitas pessoas: trata-se da intensa desigualdade econômica. Com a crise financeira mundial de então, o artista mostra-se sensível ao aspecto da sobrevivência dos trabalhadores assalariados e dos segmentos mais baixos das camadas médias, que foram os que mais sofreram privações materiais com suas conseqüências.

${ }^{372}$ Idem, ibidem. 


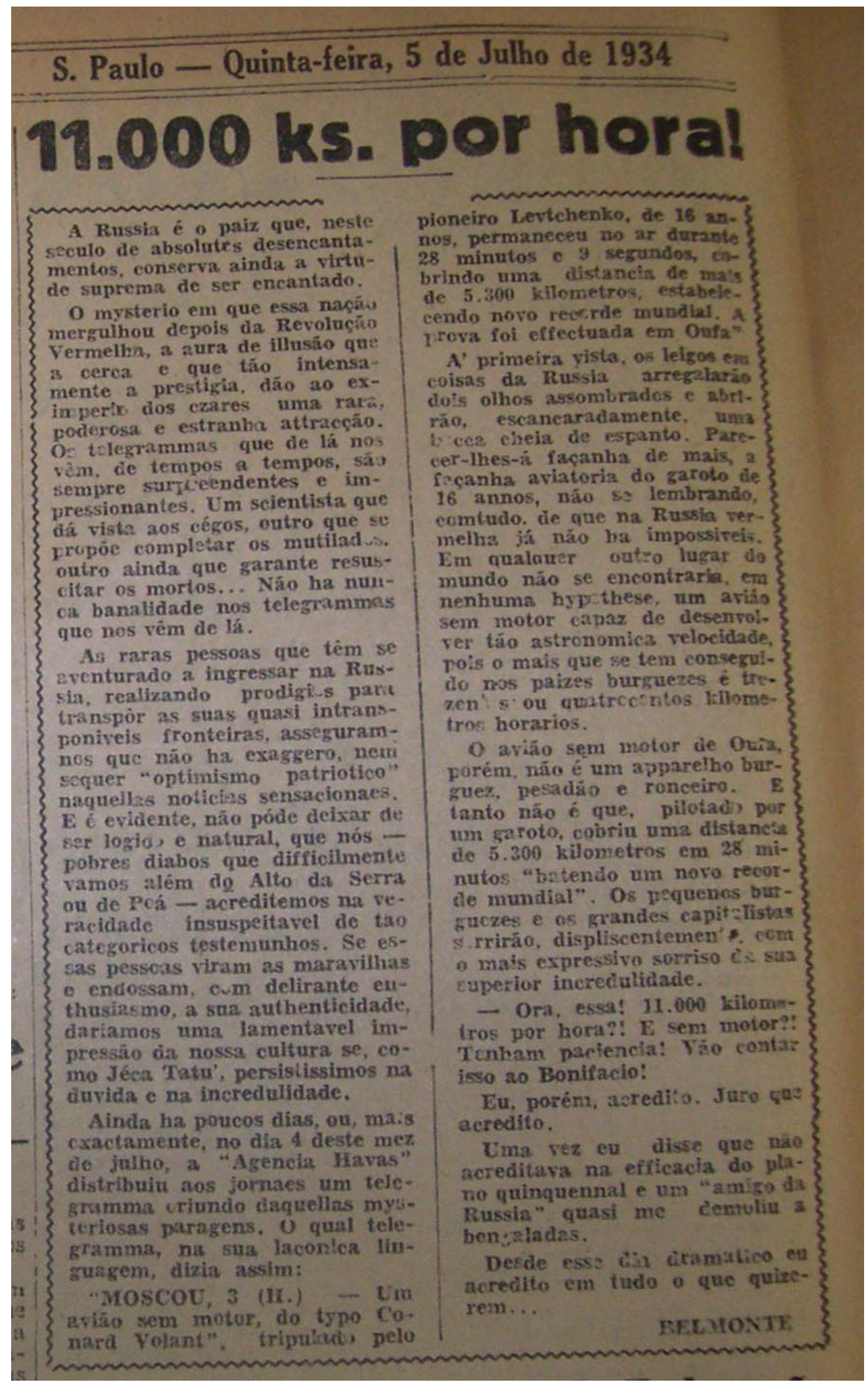

Fig. 15. 11.000 ks. por hora. BELMONTE.

Folha da Noite (São Paulo), 05/07/1934, p. 2.

Hemeroteca do Arquivo da Folha de São Paulo. 


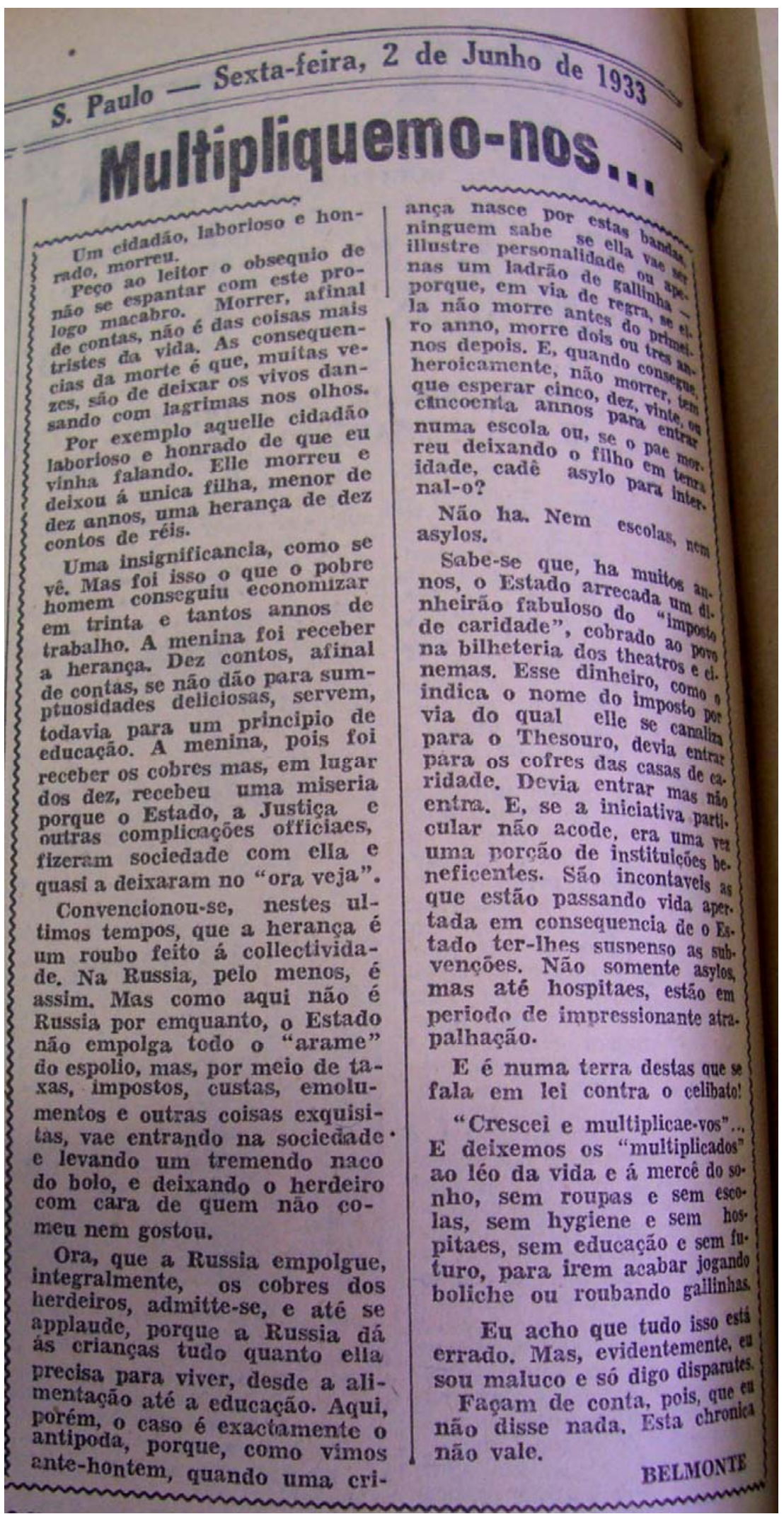

Fig. 16. Multiplique-mo-nos. BELMONTE.

Folha da Noite (São Paulo), 02/06/1933, p. 2.

Hemeroteca do Arquivo do Estado de São Paulo - AE/SP. 
Certamente, por tudo o que já foi colocado e analisado nestas páginas, parece-nos claro que o ideário político do Nazi-fascismo foi muito mais combatido e repudiado pelo humorista do jornal Folha da Noite do que aquele da(s) esquerda(s).

Belmonte não era comunista e, ao que parece, jamais o foi e nem o seria. Como já ficou evidente, ele identificava-se com o liberalismo. É sabido que os anos 30 foram marcados pela polarização entre esquerda e direita e em especial no caso daqueles grupos imiscuídos na produção artística: literatos, ensaístas e artistas plásticos. João Luiz Lafetá afirma ${ }^{373}$, assim como Antonio Candido, que a literatura se tornou mais engajada nos anos 30. Após a libertação estética impulsionada pelo Movimento Modernista nos anos vinte, a década seguinte é iniciada com uma outra proposta:

(...) O ardor de conhecer o país. A sua expansão coincidiu com a radicalização posterior à crise de 1929, que marcou em todo o mundo civilizado uma nova fase de inquietação social e ideológica (...). A alegria turbulenta e iconoclástica dos modernistas preparou, no Brasil, os caminhos para a arte interessada e a investigação histórico-sociológico do decênio de $30 .{ }^{374}$

Na obra Intelectuais à Brasileira, Sergio Miceli analisa a estrutura financeira e as relações profissionais de romancistas, poetas, contistas e memorialistas dos anos 1920-40 e enfatiza as carreiras realizadas nas capitais do Rio de Janeiro e de São Paulo. Segundo esse autor, a radicalização das posições políticas de parcela considerável da intelectualidade paulista se intensificou após as derrotas de 1930 e 1932. Observando a movimentação dela, percebemos que a "direita" do modernismo, até então no PRP, agrupa-se em sua maioria no Integralismo de Plínio Salgado. A “esquerda” modernista e militante, por sua vez, aglutina-se em torno de Oswald de Andrade, reconhecidamente um filiado do Partido Comunista Brasileiro ${ }^{375}$.

Ainda que parcelas significativas dos escritores paulistas da época tenham optado pelo engajamento no Integralismo ou no Comunismo, nem todos os artistas escolheram uma das extremidades políticas. Lembremos da presença peculiar de Mário de Andrade e Paulo Duarte, ambos liberais e favoráveis aos regimes democráticos. O grande escritor modernista Mário de Andrade foi

\footnotetext{
${ }^{373}$ Ver João Luiz Lafetá, 1930: a crítica e o modernismo. São Paulo: Duas Cidades/Editora 34, 2000, p. $227-228$ e 231.

${ }^{374}$ Ver Antonio Candido, 2000, p. 114-115.

${ }^{375}$ Ver Sérgio Miceli. Intelectuais à Brasileira. São Paulo: Companhia das Letras, 2001, p. 102-103.
} 
simpático ao Comunismo, mas jamais filiado ao PCB. Durante a década de 20, participou discretamente do Partido Democrático ${ }^{376}$.

Paulo Alfeu Junqueira de Monteiro Duarte (1899-1984) foi um intelectual que prezava profundamente o liberalismo e o regime democrático. Anti-getulista assumido, participou ativamente da Revolução Constitucionalista, o que lhe rendeu um curto exílio na Europa. Alguns anos depois, ao se voltar contra o golpe do Estado Novo, ele se viu novamente forçado a abandonar o Brasil, e dessa vez por nove anos. Paulo Duarte se tornou conhecido como escritor por meio de memórias instigantes, onde narrou a sua luta como "revolucionário" e "constitucionalista" contra o autoritarismo dos getulistas. Segundo Duarte, estes traíram os (supostos) princípios liberais e democráticos da Aliança Liberal. Assim, ele afirma que

O Movimento de 1932 foi feito não contra 30, mas para repor 1930 em seus princípios violados e conspurcados por Getúlio e pelos tenentes. ${ }^{377}$

Belmonte era um escritor antifascista. Logo, sentia aversão à extrema-direita e estava empenhado em renegá-la e desvalorizá-la, mas, concomitantemente, ele não se ligou às esquerdas. Os indivíduos que se posicionavam publicamente contra os fascismos, naqueles tumultuados anos da década de trinta, tinham em comum a filiação ou a simpatia aos partidos de esquerda: militavam, sobretudo, no PCB e na Aliança Nacional Libertadora. Nesse sentido, o artista parece ter pertencido a uma minoria, pois não pendera para a filiação em nenhum dos grupos antifascistas existentes.

Podemos afirmar, portanto, que, de 1932 a 1935, a singularidade do antifascismo de Belmonte está justamente na sua precocidade frente ao panorama da imprensa liberal e burguesa da primeira metade dos anos 30 (que, no geral, elogiava o Nazi-fascismo ou se calava perante ele, como já foi observado), e no fato do cronista não ter se alinhado aos ideários ou grupos de esquerda.

Devemos, igualmente, sublinhar a independência opinativa do artista com relação ao tema, demonstrada por meio do repúdio ao Nazi-fascismo - diferentemente da posição discreta dos editoriais da Folha da Noite. E o fato de o cronista colaborar com o jornal do grupo Folha, que se

\footnotetext{
${ }^{376}$ Ver João Luiz Lafetá, op. cit., p. 189.

${ }^{377}$ Ver Paulo Duarte. Memórias: inteligência da fome. Volume 2. São Paulo: Hucitec, 1975, p. 30, apud Sherloma Starlet Fonseca. "Memórias de Paulo Duarte: momentos da escrita e luta anti-getulista”. In: Revista Espaço Acadêmico. Maringá: Universidade Estadual de Maringá, volume 82, (3), 2008, p. $05 . \quad$ Disponível em http://www.espacoacademico.com.br/082/82fonseca.htm.
} 
manteve praticamente em silêncio perante a ascensão dos fascismos, não foi impedimento para ele expressar suas firmes opiniões sobre o tema.

Talvez Belmonte poderia ter se posicionado como antifascista se trabalhasse em um outro grande jornal da época, como O Estado de São Paulo, que manifestou em parte de seus editoriais posições condescendentes, e por vezes simpáticas, aos regimes de Mussolini e Hitler, mas, certamente, teria sido muito mais difícil.

Ao desvalorizar o Nazi-fascismo em seus escritos, Belmonte procurava influenciar politicamente o grupo social que constituía a maior parte de seu público leitor: as classes médias. Foram exatamente esses extratos sociais que, nos anos 30, ofereceram maior apoio ao Integralismo, segundo Marilena Chauí ${ }^{378}$. Isto nos leva a pensar que o artista buscava alertar seu público leitor para as prováveis ameaças constitutivas do pensamento fascista e integralista. Por outro lado, dependente da opinião de seus leitores para prosseguir como colaborador do jornal, Belmonte tinha que expressar suas concepções políticas tomando certos cuidados. Se uma parcela dos indivíduos que o lia era, provavelmente, integralista ou simpatizante do movimento, Belmonte procurou publicar suas crônicas antifascistas com o espaçamento de dias ou, até mesmo, de semanas, e sem transformá-las na temática mais presente de seu trabalho, uma vez que 10\% de seus escritos explicitavam repúdio ao Nazi-fascismo. Sim, o artista almejava criticá-lo, mas, ao mesmo tempo, não queria e não podia parecer antipático perante frações de seus leitores.

Se a Folha da Noite ainda não era declaradamente antifascista, certamente não lhe agradaria contar com a colaboração de um escritor e caricaturista que, com constância, desagradava seu público leitor. E havia a censura, por meio da qual o Estado procurava vigiar e cercear a produção cultural do país. Nesse sentido, Belmonte tinha que ser muito prudente e, ao mesmo tempo, perspicaz ao colocar sua opinião. Definitivamente, não eram apenas os dançarinos alemães que "andavam na cordabamba”: o cronista da Folha também parecia estar sempre se equilibrando entre o desejo de se expressar e a possibilidade de realizá-lo.

Belmonte escreveu no entre-guerras, sob o receio da eclosão de um novo conflito. Período instável, conturbado, descrente das propostas do liberalismo, e no qual as massas desesperançadas e pauperizadas, sobretudo na Europa, ansiavam ardentemente por alguma revolução, por um líder extraordinário, que inaugurasse uma nova e grandiosa Era e lhes restituísse o otimismo no futuro. A Alemanha e a Itália depararam-se com Hitler, Mussolini e seus respectivos regimes, que prometiam essa tão esperada Era para seus povos.

${ }^{378}$ Cf. Marilena Chauí, 1978, pp. 53-54 e 63-65. 
Em contrapartida, no Brasil, se tomarmos como referência a pouca boa vontade que o governo, seus apoiadores e os militares dispensavam para com a democracia, a ditadura parecia ser o caminho mais provável. Os governos nazi-fascistas e o de Getúlio Vargas tinham alguns aspectos em comum e, nas linhas e entrelinhas de suas crônicas, Belmonte soube explorá-los e evidenciá-los com muito talento. As semelhanças entre esses regimes encontravam-se tanto no discurso valorizador de um povo supostamente uno, sem conflitos, como naquele que confirmava seus governos como uma novidade absoluta, uma regeneração para o Volk, a razza e a nação brasileira, que, a partir de então, ficariam livres dos degenerados e dos carcomidos exploradores e caminhariam com confiança para frente. Nesse sentido, ao fazer uma contrapropaganda do Nazi-fascismo, Belmonte atingia o governo de Getúlio Vargas, direta e indiretamente.

E qual seria, no futuro, a amplitude de uma possível ditadura brasileira, uma vez que o governo possuía aspectos de confluência com o Nazi-fascismo? Ela poderia alcançar características tão exageradamente autoritárias, como aquelas apresentadas pelos regimes de Hitler e Mussolini? Estas eram, possivelmente, as perguntas que causavam as maiores apreensões em Belmonte.

As crônicas nos apresentam a impressionante clarividência do artista; afinal, alguns anos antes da implantação do Estado Novo, ele percebera as fortes tendências autoritárias implícitas no getulismo e as apreendeu como que inseridas num crescimento contínuo. Cabe destacar que nem mesmo a Constituição de 1934 lhe ofuscou a percepção de que o novo governo caminhava, indubitavelmente, para o aprofundamento das estruturas autoritárias. E a história lhe daria razão, pois, nos anos seguintes, foi largamente empregado o Estado de Sítio, com o aperfeiçoamento dos aparatos repressivos do Estado (a polícia política e o exército). E com a Lei de Segurança Nacional estabelecida no primeiro semestre de $1935{ }^{379}$ houve a intensificação da censura.

\footnotetext{
${ }^{379}$ Ver Ângela de Castro Gomes. “Confronto e Compromisso no Processo de Constitucionalização (1930-1935)”. In: FAUSTO, Boris (org.). História Geral da Civilização Brasileira - Sociedade e política (I930 - 1964) - volume III. São Paulo: Difusão Européia do Livro, 1984, pp. 73-74.

Durante o período em que o governo é praticamente exercido pelo chefe do Executivo Federal, de abril de 1935 em diante, as principais bases de sustentação de Getúlio Vargas no Congresso foram as bancadas de Minas Gerais, Bahia e São Paulo. Tal fato ilustra bem os limites da defesa dos princípios liberais empreendida pelos parlamentares paulistas. Seu liberalismo procurava reagir aos progressos da centralização política e ao controle do aparelho de Estado pelos tenentes, mas mostrava seu temor ante os avanços crescentes da participação política popular. Desde o segundo semestre do ano anterior, nas grandes cidades, os operários e parcela das classes médias, em parte capitaneada pela ANL, se insurgiam por meio de greves e reivindicações contra a inflação e a alta do custo de vida. Os deputados paulistas, desassossegados, preferiram se unir ao governo Vargas e apoiar a aprovação da LSN. Sobre esse assunto, ver Edgard Carone, op. Cit., pp. 331-332. Cf. também Maria Helena Capelato, 1989, pp. 205-206.
} 


\section{Os (Des)Caminhos da Modernidade}

Percebemos nas crônicas de Belmonte um sentimento de profundo desconforto perante a modernidade, especialmente com relação ao desenvolvimento da ciência e da técnica. Ela é apontada constantemente como uma promessa frustrada, uma farsa violenta e não-controlável. Nesse sentido, a concepção do artista é diretamente oposta àquela que pertencera à otimista e exultante burguesia européia da Belle Époque $e^{380}$. É, também, sensivelmente divergente da concepção adotada por grande parte da imprensa paulista liberal e burguesa da época, que encarava os avanços científicos e tecnológicos, além da impressionante abundância material de poucos, de modo acrítico ${ }^{381}$.

A ausência de crítica à modernidade por parte dessa mesma imprensa foi imensamente favorecida pela influência cultural que ela recebera das elites burguesas européias no século XIX e nas primeiras décadas do XX, sendo que suas idéias defendiam o culto ao liberalismo e aos avanços científicos, que trariam, segundo essa lógica, o progresso, a possibilidade de maior riqueza material e conforto para grandes parcelas da humanidade.

Compreendemos a modernidade como o desdobramento do ideário iluminista e ilustrado, que, sustentando-se na razão, propugnava a defesa do indivíduo frente a quaisquer decisões unilaterais, repudiando com veemência as relações autoritárias, estivessem elas no âmbito da religião, da política ou da organização social (pelo menos teoricamente). Na modernidade, o desenvolvimento do pensamento racional e cientifico e a expansão da educação intelectual para as massas passaram a ocupar uma maior importância, indubitavelmente.

Nos séculos seguintes, os herdeiros e prosseguidores do pensamento iluminista configuraramse no Liberalismo e no Socialismo. Nas propostas de igualdade e liberdade jurídicas, valorização da razão e da individualidade, desenvolvimento das forças produtivas e democracia formal, de acordo com o primeiro, e nas propostas de apropriação das forças produtivas pela coletividade, valorização da razão e da individualidade, igualdade, liberdade e democracia efetivas, no caso do segundo ${ }^{382}$. Mas, para as elites burguesas das sociedades ocidentais capitalistas, o paradigma de modernidade situava-se exclusivamente nas propostas do Liberalismo. Os movimentos socialistas que se fortaleciam e conquistavam adeptos, sobretudo entre os proletários, figuravam para os defensores do

\footnotetext{
${ }^{380}$ Ver Eric Hobsbawm. A Era dos Extremos. São Paulo: Companhia das Letras, 1998, p. 16.

${ }^{381}$ Ver Maria Helena Capelato, 1989, p. 233 a 246 passim.

${ }^{382}$ Paulo Sérgio Rouanet. “Introdução”. In: As Razões do Iluminismo. São Paulo: Companhia das Letras, 1999, p. 25 e 27. Ver do mesmo autor "Iluminismo ou Barbárie. A crise da civilização moderna”. In: Mal-estar na Modernidade: ensaios. São Paulo: Companhia das Letras, 2003, p. 9 a 41 passim.
} 
Liberalismo como uma inversão absoluta do que sempre deveria ser a ordem natural: os ricos e “bem-educados” prosseguindo no topo das classes sociais.

Não eram as propostas originais da modernidade que Belmonte rejeitava, tal como a valorização da razão, a expansão da instrução para o maior número de pessoas, individualidade, progresso material, democracia, liberdade e igualdade jurídicas; indubitavelmente, ele sentia profunda simpatia por elas. Mas o artista denunciava justamente a deturpação do projeto de modernidade, que se concretizava a passos largos. Esta, completamente desviada de seus ideais primeiros, tornara-se o pólo oposto das propostas iluministas e ilustradas elaboradas nos séculos XVII e XVIII. E, por meio do desenvolvimento científico e da técnica, favoreceu-se de um modo inédito o controle total da natureza e dos homens, possibilitando, assim, a dominação e a coisificação de qualquer espécie de vida sobre a Terra.

Segundo Paulo Sergio Rouanet, o desenvolvimento do pensamento racional deveria ter como função a universalização do emprego dos conhecimentos científicos, para que eles pudessem ser usados em favor do maior número de indivíduos. Todavia, a subjugação das pessoas, reforçada pelas próprias descobertas científicas dos últimos cento e cinqüenta ou duzentos anos, não fazia parte do pensamento iluminista e ilustrado do século XVIII: "Seu ideal de ciência era o de um saber posto a serviço do homem, e não o de um saber cego, seguindo uma lógica desvinculada de fins humanos. ${ }^{383}$

De qualquer modo, era inegável que, desde os princípios de 1900 até aqueles tumultuados anos da década de trinta, a impiedosa exploração capitalista sobre o trabalhador, a Primeira Guerra Mundial e a administração crescente do tempo da vivência cotidiana e do trabalho industrial ${ }^{384}$ - nas quais quase sempre o desenvolvimento técnico-científico fazia as vezes de instrumento de controle e subjugação - perderam os objetivos das propostas do Iluminismo, da Ilustração e, consequentemente, do Liberalismo, ao mesmo tempo que os desacreditavam perante a imensa massa de trabalhadores e as camadas médias (sobretudo das nações européias).

\footnotetext{
${ }^{383}$ Paulo Sergio Rouanet. "Introdução”. In: As Razões do Iluminismo. São Paulo: Companhia das Letras, 1999, p. 27. ${ }^{384}$ A produção industrial também sofreu a interferência de métodos organizacionais embasados cientificamente. Foi o caso do Taylorismo. Este se voltou para a imposição de parcelamento das tarefas e intensa repetição de gestos e movimentos; exigiu, portanto, um novo e extraordinário desgaste dos trabalhadores industriais, além de um rígido controle sobre eles. Sobre este assunto, ver o livro de Maria Antonieta Antonacci. A Vitória da Razão(?). O IDORT e a Sociedade Paulista. São Paulo: Marco Zero, 1993, em especial as páginas 36-71 passim.
} 


\subsection{O Mal-estar na Modernidade}

Sabe-se que, anterior ao período do entre-guerras, em especial nas artes e na filosofia, o sentimento de desconforto perante a modernidade manifestou-se principalmente de 1870 a 1900, na Europa, e foi nomeado mal-estar de fin-de-siècle. Estes anos foram aqueles em que, no terreno da cultura, se produziu um enérgico gênero de cultura burguesa sobre o declínio e a queda da civilização moderna ${ }^{385}$. "Degeneration, do futuro sionista Max Nordau (1893), é um bom exemplo. E Nietzsche, o eloqüente e ameaçador profeta de uma catástrofe iminente, cuja natureza exata ele não definiu muito bem, expressa melhor que ninguém essa crise das expectativas.”386

Dotado de grande verve irônica, o filósofo alemão concluiu que “.... pessimismo e o niilismo dos anos 1880 eram mais que uma moda. Eram o resultado final lógico dos grandes valores e ideais da moderna sociedade ocidental" ${ }^{387}$. Ele sustentava que eram as energias vitais que mereciam o verdadeiro status de dignidade, e não a razão. As vontades foram represadas por séculos por autolimitações de origem racional, e estas deviam ser completamente destruídas para que houvesse a libertação do homem. Em sua filosofia, a burguesia é denunciada como culpada pela inautenticidade da vida social, pelo fracasso das iniciativas humanas e pela total negatividade da história humana. Para existir é preciso querer existir, mas, se é preciso lutar para existir, chega-se à conclusão de que há no mundo forças negativas que se opõem à existência. A existência é, sublimemente, autocriação, mas, se o mecanismo estritamente racional do trabalho industrial é anticriativo, ele se torna destrutivo para os seres humanos ${ }^{388}$. Logo, “...a história intelectual das décadas após 1875 é repleta do sentimento de expectativas não apenas logradas (...) mas que de certa forma estavam se transformando em seu oposto” ${ }^{389}$.

Nietzsche recebeu influências de dois grandes filósofos antecessores a ele, Søren Kierkegaard (1813-1855) e Arthur Schopenhauer (1788-1860). Este, arraigado em um profundo pessimismo existencial, considerava a razão impotente para fornecer contribuições reais, duradouras ao conhecimento, pois o mundo para ele não dependia da razão enquanto tal, mas da vontade da vida, anterior a qualquer racionalidade. Para Kierkegaard, havia a defesa da realidade vivida,

\footnotetext{
${ }^{385}$ Cf. Eric J. Hobsbawm. A Era dos Impérios (1875-1914). 8 a edição. São Paulo: Paz e Terra, 2003, p. 358-359.

${ }^{386}$ Idem, ibidem, p. 359.

${ }^{387}$ Nietzsche, Wille zur Macht, Vorrede, p. 4, in: Idem, ibidem. Cf. também Robert Owen Paxton, op. Cit., p. 64-65.

388 Cf. Giulio Carlo Argan. Arte Moderna. Do Iluminismo aos Movimentos Contemporâneos. 9a edição. São Paulo: Companhia das Letras, 2004, pp. 240-241. Ver também Ricardo Timm de Souza. "Filosofia e Expressionismo”. In: GUINSBURG, J. (org.). Op. cit., pp. 90-91.

${ }^{389}$ Cf. Eric J. Hobsbawm, op. Cit., p. 359.
} 
compreendida como incomparavelmente importante. Percebe-se em sua filosofia uma forte valorização de elementos subjetivos vividos, em oposição a uma objetividade fria ${ }^{390}$.

As décadas finais do século retrasado assistiram a uma efervescência crítica entrecortada por concepções pessimistas (e um tanto melancólicas) não apenas na literatura e na filosofia européias, mas também nas artes plásticas. Símbolo de um cromatismo vívido, violento e permeado pela paixão, a arte do pintor holandês Vincent Van Gogh flertava com o instintivo e o emocional e se opunha tenazmente à alienação e à mistificação do trabalho moderno e industrial, se voltando igualmente contra a técnica mecânica despersonalizante, evidentemente intrínseca a ele ${ }^{391}$.

Seu colega Paul Gauguin (1848-1903), pintor extremamente criativo e imaginativo, também dispensou pouca boa vontade com relação à modernidade, que, na sua visão, colocara o homem sob o controle do ritmo das máquinas e dominado por relações impessoais. Gauguin buscou simplificar ao máximo sua composição pictórica, inspirando-se em sociedades não-industriais. Se, para dar um sentido ativo à função da imaginação é preciso afastar-se da sociedade moderna, é porque nela não há mais espaço e nem tempo para a imaginação. O desejo de Gauguin de reencontrar a vida numa sociedade tradicional, como a da Bretanha, ou "não-civilizada", como a do Taiti, foi a expressão máxima de sua insatisfação perante a sociedade capitalista ${ }^{392}$.

Outro pintor contemporâneo a Paul Gauguin foi Henri de Toulouse-Lautrec (1864-1901). Suas obras imortalizaram o desgaste e a melancolia das prostitutas e trabalhadores da vida noturna de Paris, que tinham seus corpos e sua dignidade consumidos pela pobreza, pelo álcool e pela privação de sono. Eram cores e formas que revelavam inúmeros seres humanos degradados, porque coisificados, “consumíveis”.

Mas o pessimismo e o mal-estar perante a modernidade encontravam-se restritos a alguns artistas e intelectuais de vanguarda. Para muitos europeus, os anos finais do século XIX corriam sob o signo do progresso. O grande símbolo deste à época configurou-se, indubitavelmente, na Tour Eiffel (1889), pois a sua construção não fora mais do que a representação do triunfo da razão humana, da matemática e da engenharia, diante das forças decadentes do passado, com seus monarcas déspotas, superstições e bispos inquisidores, e a orgulhosa demonstração da capacidade de planejamento dos seres humanos. Monumento admirável, tornado possível graças aos avanços na produção impulsionados pela Segunda Revolução Industrial, aquele gigante de aço assemelhava-se,

\footnotetext{
${ }^{390}$ Cf. Ricardo Timm de Souza, op. cit., pp. 87-89.

${ }^{391}$ Cf. Giulio Carlo Argan, op. Cit., p. 124.

${ }^{392}$ Idem, p. 130-131.
} 
metaforicamente, a uma impertinente criatura que subia aos céus, como se quisesse se posicionar ao lado do Criador a partir da perícia técnica conquistada pelos homens.

Entre as décadas de 1870 a 1914, o otimismo no progresso, o mesmo que circundou o planejamento e o soerguimento da Tour Eiffel, parecia ter se espalhado da elite burguesa a largas parcelas das classes médias européias ${ }^{393}$. De fato, era difícil negar que ocorrera uma sensível melhoria em suas condições de vida. O aumento da estatura humana a partir de 1880/1890 aponta isso, e a nutrição configurou-se na explicação mais plausível para esse crescimento físico. Nas regiões “desenvolvidas” da Europa, morrer de fome já não era mais uma contingência possível. E mesmo na “atrasada” Espanha, a última fome de grandes proporções ocorreu na década de $1860^{394}$.

Concomitantemente, as classes médias e parte das classes trabalhadoras ${ }^{395}$ alcançaram uma elevação no seu nível de instrução. As primeiras, certamente, conseguiram ir mais além. Mas, de qualquer modo, não podemos ignorar que, na Grã-Bretanha, durante as guerras napoleônicas, as cartas enviadas anualmente por habitante chegavam, no máximo, a duas por ano. Já em 1885, elas atingiram quarenta e duas por habitante. Em 1880, as pessoas que se dedicavam à ciência eram, talvez, 44 mil, provavelmente quinze vezes mais do que cinquenta anos antes. E a mudança das instituições políticas nos países “desenvolvidos”, que caminhavam na direção do constitucionalismo liberal e da democracia, podia ser considerada como mais um dos sinais do progresso ${ }^{396}$.

Até mesmo os trabalhadores industriais tiveram, em fins do século XIX, uma certa melhoria em suas condições de vida (principalmente ingleses e franceses). Seus salários aumentaram de valor e, destes anos em diante, passou a ser crescente o número de crianças alemãs, francesas e inglesas, filhas de proletários, que frequentavam os bancos escolares por pelo menos alguns anos.

Portanto, para a elite européia e para parte das pessoas comuns, estes anos foram marcados por extraordinários êxitos científicos e materiais. Conforme as palavras de um eminente historiador, a esperança e o otimismo eram a tônica daquela época:

\footnotetext{
${ }^{393}$ Referimo-nos à crença no progresso situada em grupos ou organizações que estavam em conformidade com o sistema capitalista, o que, naturalmente, não incluía a imensa massa de trabalhadores comunistas e anarquistas (que participavam de sindicatos e partidos veementemente críticos do capitalismo).

${ }^{394}$ Cf. Eric Hobsbawm. Era dos Impérios (1875-1914). $8^{a}$ edição. São Paulo: Paz e Terra, 2003, p. 50.

395 É pertinente observar que, mesmo no mundo "desenvolvido", o percentual que representava a elite e as camadas médias era bastante pequeno se comparado com o total da população. Na França, por exemplo, segundo a Classificação Oficial Francesa dos Funerais da Republica, nos anos de 1870, cerca de 3,5\% eram ricos, 14\% de classe média e 82-83\% compunham as classes trabalhadoras. Entretanto, mesmo assim, era difícil negar uma certa melhoria nas condições das pessoas comuns. Idem, Ibidem.

${ }^{396}$ Cf. Eric Hobsbawm, op. Cit., p. 51.
} 
Nunca um número maior de homens e mulheres, cujo acesso à cultura era recente e que eram intelectualmente conscientes, acreditou mais firmemente no que as avantgardes, mesmo então, estavam rejeitando. Se os pesquisadores da opinião pública, no mundo desenvolvido pré-1914, tivessem comparado o percentual de esperança ao de mau agouro, o dos otimistas ao dos pessimistas, a esperança e o otimismo com toda certeza teriam prevalecido (...). Mas, é claro, esse otimismo incluía não só os que acreditavam no futuro do capitalismo, mas também os que aguardavam, esperançosos, sua superação. ${ }^{397}$

Entretanto, o sonho burguês de controle científico absoluto sobre o trabalho e a natureza, sustentado por suas criações mais impressionantes - o aço, o alumínio, o concreto armado, o motor a combustão, os geradores e a eletricidade -, chocou-se repentinamente com os canhões fumegantes da Primeira Guerra Mundial. Com o seu advento, talvez pela primeira vez após várias décadas, os habitantes “civilizados” do globo se deram conta das possibilidades profundamente ambivalentes das criações científicas, da tecnologia e da modernidade. Pela primeira vez, os canos dos inovadores instrumentos bélicos não eram apontados para os insubmissos trabalhadores de esquerda e para os orientais, indígenas e africanos “atrasados” e "bárbaros”, mas sim na direção dos próprios europeus, independentemente de sua classe social de origem ou posicionamento político. Logo, as inovações técnicas passaram a representar não mais apenas a engenhosidade humana e o deslumbramento para com a ciência, mas também a morte.

A segunda metade do século XIX contemplara o surgimento de inventos maravilhosos, ainda que atordoantes: o telégrafo, o telefone, o automóvel, a luz elétrica e a imagem em movimento (o cinema); utilitários esses que, evidentemente, facilitaram e dinamizaram a vida daqueles que puderam ter acesso aos seus produtos. Por outro lado, essa mesma modernidade revolucionou a guerra com as bombas despejadas por aeroplanos. E ela criou ainda os tanques blindados, as metralhadoras e o gás venenoso.

As mortes nos conflitos bélicos nunca mais foram contabilizadas como outrora, aos milhares, mas sim aos milhões. Nesse sentido, a Primeira Guerra Mundial foi o grande marco do belicismo moderno não apenas devido à mortandade que ela desencadeou, mas principalmente porque alvejou a

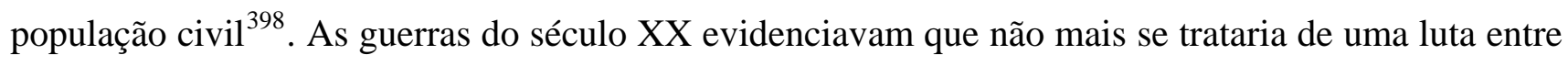

\footnotetext{
${ }^{397}$ Idem, p. 26.

${ }^{398}$ Ver Eric J. Hobsbawm. A Era dos Extremos. São Paulo: Companhia das Letras, 1998, pp. 22-23 e pp. $51-59$ passim.
} 
exércitos profissionais, mas entre nações. Portanto, o número de envolvidos passou a ser infinitamente maior.

Se o desconforto perante a modernidade já não era algo novo no período em que Belmonte escreveu suas crônicas, o que se configurou como absolutamente inédito foi que o pessimismo e o descrédito referentes a ela não mais permaneceram restritos a seletos grupos de intelectuais e artistas: disseminaram-se entre os homens comuns, originários, em sua maioria, de parcelas não-politizadas da classe trabalhadora e das classes médias. Afinal, antes de 1914, ninguém poderia ter imaginado tanta brutalidade e violência naquela que era vista como a região mais civilizada do mundo - a Europa. No século anterior, as guerras foram localizadas, curtas, pouco freqüentes, e lutadas por exércitos profissionais que quase nunca envolviam a sociedade civil. Mas quando um conflito nos Bálcãs fugiu do controle, em 1914, transformando-se numa guerra de porte entre os grandes países europeus, e quando ela foi prolongada por mais de quatro anos, matando e mutilando toda uma geração de jovens, pareceu a muitas pessoas que a civilização européia ocidental (paradigma para as sociedades do Ocidente e até mesmo para algumas do Oriente) havia fracassado estrondosamente, carregando em sua derrocada todas as suas promessas de paz e progresso ${ }^{399}$. E, em fins da década seguinte, essa descrença no progresso foi intensificada com a crise econômica.

Em suas crônicas, Belmonte corroborava com a opinião de grande parte dos europeus que lhe eram contemporâneos: as máquinas e técnicas que outrora (nos séculos XVIII e XIX) foram promessas de melhoramento para a humanidade tornavam-se agora terríveis algozes. Conforme as lições tiradas da I Guerra Mundial, elas estavam muito mais direcionadas para o massacre do que para a cura. O cronista especifica em suas linhas a diferença existente entre um progresso simplesmente técnico e um progresso ético, verdadeiramente substancial; ao mesmo tempo em que cientistas criam automóveis e aviões para diminuir as distâncias entre os homens e remédios para livrá-los de males, elaboram também aviões de guerra e armas de alta precisão. Para o artista, a modernidade configurava-se por vezes como paradoxal, ambivalente, ainda que ele salientasse com mais frequência os seus aspectos negativos.

${ }^{399}$ Cf. Robert Owen Paxton, op. Cit., p. 59. 


\subsection{Uma Modernidade Paradoxal}

Belmonte, um homem que viveu à época da I Guerra Mundial e conheceu-a detalhadamente pela leitura dos jornais, captou, atônito, a capacidade destrutiva da tecnologia empregada. E naqueles idos de 1933-35, ele percebeu, também, a indubitável ameaça que a humanidade corria pelo fato de armas modernas e potentes pertencerem aos exércitos de Estados autoritários e imperialistas, sedentos de territórios e bens econômicos.

Na crônica Morrer por Morrer..., ao comentar sobre a Primeira Guerra Mundial, o artista informa seus leitores de uma impressionante notícia publicada em um diário norte-americano. Por meio dela, Belmonte salienta, espantado, a incrível potencialidade de assassinar aos milhões que foi inaugurada, ineditamente, com o conflito de 1914-1918. Ele destaca o uso do gás venenoso (que, nesse caso, teve como elemento principal o cloro) como possibilidade de eliminar muitos seres humanos em um curto espaço de tempo, e em apenas uma das batalhas da referida guerra:

O peor é a loucura dos vivos. Estes é que andam por ahi numa tarefa sinistra, inventando coisas sinistras para seu próprio extermínio, principalmente nos domínios da chimica e, com toda a certeza, no domínio da bacteriologia.

Um jornal americano, referindo-se a esses acontecimentos de arrepiar o cabello, narrou, há pouco, o que se deu no dia 31 de maio de 1915, durante a Conflagração Européa: uma divisão siberiana do exercito russo, com o effectivo de nove mil homens, foi inteiramente dizimada - não pelas baionetas, nem pelos fuzis, nem pelas granadas - mas pelo chloro.

Dos nove milhares de homens atacados, não ficou nenhum para contar a historia. Se isso ocorria há quasi vinte anos atrás, não é diffícil imaginar o que acontecerá daqui a algum tempo. ${ }^{400}$ [grifos nossos]

Se nos atermos à história dos armamentos, o début do gás tóxico realmente ocorreu no primeiro semestre de 1915. Em fins do mesmo ano, os franceses empregaram granadas de fosgênio nas batalhas, e essas armas tiveram uma grande repercussão. E, em 1916, os alemães começaram a usar o temível gás mostarda. Todas essas armas químicas podiam ser letais e, quando não matavam o soldado, abriam repugnantes feridas em sua pele, debilitavam-lhe dramaticamente o sistema

${ }^{400}$ Belmonte, Morrer por Morrer... Crônica publicada na Folha da Noite (São Paulo) em 21/12/1933, p. 2. 
respiratório e, não raramente, cegavam-no. O gás venenoso, esse inimigo sem forma e traiçoeiro porque, se lançado durante explosões maciças de obuses, tornava-se pouco visível ${ }^{401}$, causava um pavor indescritível nos combatentes. Por meio do gás, a morte podia apoderar-se deles súbita e camufladamente. E se tinham a “desventura” de perdurarem por mais alguns dias, o sofrimento era horrendo: agonizavam cuspindo partes calcinadas de seus pulmões ${ }^{402}$.

Ao tecer considerações sobre a Primeira Guerra Mundial, Belmonte buscou, concomitantemente, conduzir a reflexão do leitor para a intranqüila década de trinta com a frase: "Se isso ocorria há quasi vinte anos, não é diffícil imaginar o que acontecerá daqui a algum tempo”. Certamente, refletir sobre o presente tratava-se de algo um tanto angustiante, pois a eclosão de um novo conflito de imensas proporções, com armas terríveis e ainda mais destrutíveis, era tomada quase que como certeza, conforme informam-nos os dois primeiros parágrafos da crônica:

\begin{abstract}
Um adivinho, falando á 'Folha da Noite' há poucos dias, declarou que dentro de muito pouco tempo, o mundo vai se metter numa nova guerra - esta, porém de uma grandiosidade espetacular e fulminante.

Creio que não é preciso ser propheta nem autoridade em sciencias mysteriosas para chegar a essa conclusão. ${ }^{403}$ [grifos nossos]
\end{abstract}

O artista coloca o aspecto ambivalente das invenções modernas, que podiam ser empregadas para confortar os seres humanos como também para eliminá-los. Mas ele inicia este parágrafo salientando o lado destrutivo das inovações científicas, alcançadas, em grande parte, devido ao formidável desenvolvimento da indústria química do século XIX:

\footnotetext{
Enquanto as usinas inventam e aperfeiçoam apparelhos complicados de matar o próximo, os grandes laboratórios chimicos, montados para fabricar remédios, fabricam venenos.
}

\footnotetext{
${ }^{401}$ Com exceção do gás mostarda, que tinha coloração amarela intensa.

${ }^{402}$ Cf. Erich Maria Remarque. Sin novedad em el frente. Barcelona: Printer, s/d, p. 38. Este romance semi-autobiográfico que discorre sobre o cruel cotidiano dos soldados na Primeira Guerra Mundial e desmistifica o heroísmo bélico foi publicado no Brasil com o nome Nada de novo no front. Em 1929, ele foi publicado na Alemanha, pátria do escritor. Em um ano e meio venderam-se mais de um milhão de exemplares. Logo em seguida, a obra foi traduzida para vários idiomas e seus exemplares se esgotaram rapidamente. Em 1930, Lewis Milestone fez um filme pacifista baseado na obra de Remarque, e sob o mesmo título. O romance e o filme, bons e impactantes, transformaram Erich Maria Remarque em celebridade mundial. Mas, com a subida do Nazismo ao poder na Alemanha, Nada de novo no front foi proibido, o escritor perdeu sua nacionalidade alemã e teve que se exilar.

${ }^{403}$ Belmonte, Morrer por Morrer... Crônica publicada na Folha da Noite (São Paulo) em 21/12/1933, p. 2.
} 
O chloro, base de quase todos os gazes asphyxiantes, é producto indispensável ás necessidades pacíficas da humanidade. Difficilimo, portanto, extinguir-lhe o commercio. $^{404}$

Prosseguindo com a exposição dos resultados advindos da engenhosidade humana na modernidade, Belmonte se utiliza do brusco contraste, engendrado pelo imprevisto, para alimentar o riso. Assim, subitamente, a morte sucede a esperança de viver, retratada nos medicamentos, e também a beleza de uma pintura paisagística:

O phosgeno e o oxicloruro são indispensáveis á industria de tinta e aos productos pharmaceuticos... mas é com elles, tambem, que se fazem bombas terríveis. De modo que, não havendo possibilidade de eliminar o commercio dessas drogas, ellas continuarão a servir para se fabricarem remédios, tintas para pintar paisagens $e$ bombas para mandar a gente para o outro mundo. ${ }^{405}$

O uso do imprevisto. Quantos e tantos sorrisos foram desencadeados por ele na vida e na arte, e não apenas na literatura de Belmonte ${ }^{406}$ ?

Na crônica Morrer por Morrer... vemos, também, todo o brilhantismo da ironia de Belmonte:

E o peor é que, dessa próxima guerra ninguém escapará, porque as gigantescas esquadras de aviação vão se encarregar de levar as bombas a toda parte, na vanguarda, na retaguarda, nos campos de cultura, nas cidades, dentro das casas, no fundo dos porões... Como disse um chronista francez, 'a aviação suprimirá as frentes de guerra e colocará toda a nação em linha de fogo’.

\footnotetext{
${ }^{404}$ Idem.

405 Idem.

406 Referimo-nos principalmente aos filmes de Charles Chaplin, grande paradigma da comicidade no cinema. Por exemplo, em uma das cenas do filme Tempos Modernos (1936), após ter cheirado cocaína involuntariamente na prisão, Carlitos torna-se valente e, ainda que baixo e franzino, enfrenta três ladrões altos, fortes e armados com revólver, que almejavam fugir. Nesse caso, o riso surge pelo imprevisto (quem imaginaria que Carlitos iria, completamente desarmado, atacar os bandidos?) e, ao mesmo tempo, pelo contraste da estatura e do físico dos homens inimigos.

Em uma outra cena, após ter saído pela segunda vez do presídio, Carlitos é levado a uma nova morada encontrada pela sua companheira, uma jovem órfã (interpretada pela atriz Paulette Goddard). Já no interior da sua “casa”, que trata-se na verdade um miserável casebre de madeira, ele encosta-se na porta. Destruída provavelmente por cupins e pela umidade, ela se desfaz de imediato; então, o personagem perde o equilíbrio e cai no riacho que circundava a morada. Assim, novamente o imprevisto se fez presente. Há, neste filme de Charles Chaplin, o uso constante do imprevisto e do contraste, assim como nas crônicas analisadas.
} 
E para que se tenha uma idéa mais exacta do que vae ser essa luta medonha, basta dizer que ella não será uma guerra. Isso de guerra é velharia. A do futuro vae se chamar, segundo nos assevera um jornalista inglez, 'um duello electro-aero-chimico.'

Não é bonito? 'Duello electro-aero-chimico!'

Exactamente como aquelle sujeito que estava agonizando no leito, mas que ficou mais alliviado quando soube que ia morrer de uma 'pneumo-thorax captaliptica (porque seria uma vergonha morrer de indigestão ou de nó na tripa), nós também podemos ficar tranquillos e satisfeitos porque iremos morrer num duello electro-aero-chimico!

Já é um consolo... ${ }^{407}$

O escritor discorre sobre as máquinas bélicas modernas, salientando o seu poder de destruição. Novamente, os avanços científicos e tecnológicos são mostrados por seu avesso, por seu contrário.

Belmonte faz referência também ao desenfreado desejo coletivo por novos produtos consumíveis, próprio das sociedades contemporâneas, quando afirma enfaticamente: “...isso de guerra é velharia”. Na época, a ânsia por novidades materiais era tão grande que a cidade de São Paulo estava repleta de propagandas que exaltavam os seus produtos com o emprego dos adjetivos “moderno”, “supermoderno”, “ultramoderno” e “revolucionário” ${ }^{408}$. Mas, simultaneamente, o artista evidencia o quanto esse encantamento pelo novo pode ser acrítico e perigoso: em tom de galhofa, Belmonte garante que todos podem se sentir "tranqüilos”, pois vão padecer de doenças ou morrer em conflitos bélicos que possuem nomes que invocam tecnologias ultra-modernas; logo, ostentam uma aparente modernidade. Embrulhada em um invólucro do moderno, a crônica sugere-nos que a morte pode parecer menos dolorosa, o que pode ser compreendido pelo leitor, concomitantemente, como uma sugestão tola e absurda; assim, as entrelinhas destas linhas incentivam-no a refletir sobre o valor e a qualidade das muitas novidades que surgiam não apenas nas prateleiras das lojas e grandes magazines, mas, também, no panorama militar e político, reflexões estas que raramente eram empreendidas nos afazeres cotidianos dos homens comuns.

\footnotetext{
${ }^{407}$ Belmonte, Morrer por Morrer... Crônica publicada na Folha da Noite (São Paulo) em 21/12/1933, p. 2.

${ }^{408}$ Praticamente toda mercadoria recebia da publicidade o adjetivo de moderno: as lâminas azuis Gilette ("o moderno processo de barbear”), o sapólio Radium, as aspirinas Bayer ("Os avanços da ciência moderna”: "Energia”, "Potência”, "Eficiência”), remédios, enlatados, roupas, vitrolas (que se opunham aos gramofones, mais "tradicionais"; elas se apresentavam, portanto, destinadas aos jovens e aos seus “ritmos modernos”), automóveis, caminhões e motocicletas. Cf. Nicolau Sevcenko, op. Cit., pp. 228-230.
} 
E, ao mesmo tempo em que o autor chama a atenção para essa a-crítica e premente fascinação por novidades, ele desvela outro aspecto incômodo do mundo moderno: o que há pouco era interessante e jovial, um instante depois não significará mais nada. Eis as facetas essenciais das sociedades na modernidade: a volatilidade e a absoluta instabilidade. ${ }^{409}$

Devemos atentar para a presença marcante da ironia na escrita de Belmonte, grande elaborador desse recurso lingüístico da comicidade. Por exemplo, quando Belmonte pergunta ao leitor: “Não é bonito? 'Duello electro-aero-chimico'!”, tendo como ponto de partida a descrição da terrível destruição proporcionada por aviões que despejam bombas de alto poder de aniquilação, podemos interpretar essa frase do seguinte modo: “Não é terrível?! 'Duello electro-aero-chimico’! Vejam a incrível capacidade de arrasamento que a humanidade desenvolveu! E nós, os homens comuns, como somos uns tolos, nos impressionamos com essas palavras novas e empoladas!” Somos, acriticamente, seduzidos pela fascinação do novo; eis a ironia oferecendo como interpretação o oposto do que foi escrito.

Em outro parágrafo, Belmonte faz novamente uso de sua ironia ferina ao afirmar que “...nós também podemos ficar tranquillos e satisfeitos porque iremos morrer num duello electro-aerochimico!”. Ora, é fora de propósito sugerir ao leitor tranqüilidade e satisfação após o detalhamento da ação de bombas terríveis que serão jogadas por aeroplanos presentes em todos os pontos do país.

409 Ver Marshall Berman. Tudo que é Sólido Desmancha no Ar: a aventura da modernidade. São Paulo: Companhia das Letras, 1986, p. 13-35 passim. 


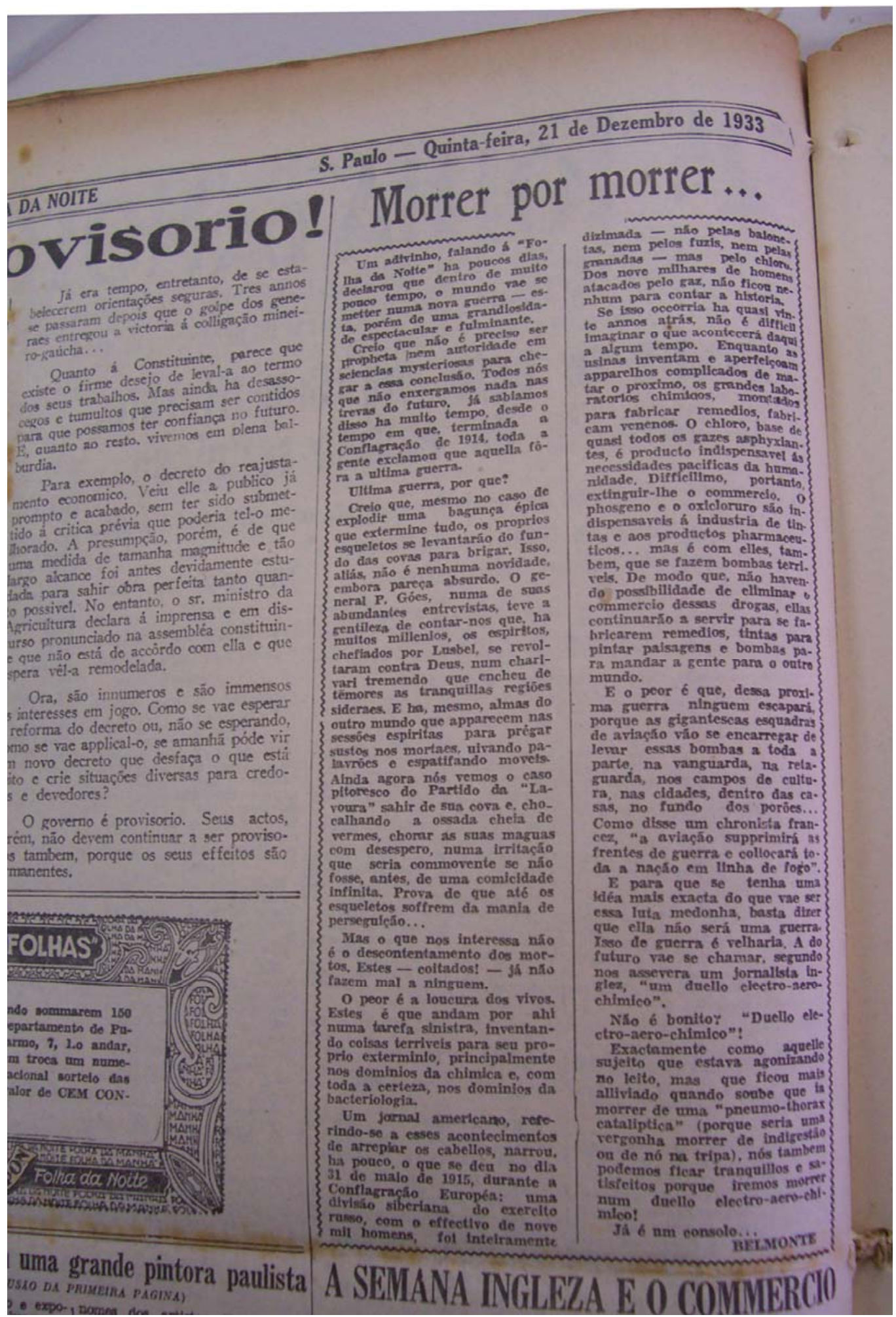

Fig. 17. Morrer por Morrer... BELMONTE.

Folha da Noite (São Paulo), 21/12/1933, p. 2.

Hemeroteca do Arquivo do Estado de São Paulo - AE/SP. 
Nas crônicas de Belmonte, a tecnologia empregada empurrava os homens para a despersonalização, a coisificação e a morte. Vejamos essa excelente crônica publicada na Folha e posteriormente no livro Idéas de João Ninguém:

Admitto, para argumentar, que a guerra fosse uma coisa mito interessante, há trinta ou quarenta annos atrás (...). Lutar peito a peito, de homem para homem, em combates francos e leaes, era alguma coisa que chegava ás raias da epopéa. Era dramático, mas era bello. Hoje, porém, não há nada disso. A guerra que se desencadeiar agora não virá aureolada de belleza, nem se caracterizará pelo heroísmo. Os homens, que deveriam enfrentar-se como leões, agirão, prosaicamente, como tatus, enfiados em buracos, num pavor soberano. Não será, uma luta de Homens, com H maiúsculo, mas um morticínio de minhocas. Haverá, porventura, grandiosidade e heroísmo numa coisa dessas?

Porque a verdade é que ninguém escapará á chacina. Constantemente, os jornaes europeus se referem aos últimos gazes creados pela chimica, a serviço da guerra, dando detalhes impressionantes sobre os gazes mais pesados que o ar, gazes que descerão ao fundo das trincheiras, das galerias e dos porões, para liquidar as minhocas inimigas. E, além dos gazes, raios ultra-violetas, raios da morte, raios negros, raios que o partam... E granadas bacteriológicas, que entrarão em scena à ultima hora... $\mathrm{E}$ torpedos imantados... E vapores nitrosos, nuvens de phosgeno... O sujeito que se metter nessa tragedia estará literalmente frito. Póde ser patriota, póde ser valente essa valentia e esse heroísmo não lhe servirão para coisa nenhuma. Diante de uma nuvem de gaz que avança á flor do solo, firme e implacável, elle não terá outro recurso senão enfiar-se pela terra a dentro, com mascara e tudo, como um tatu. Sob uma nuvem de cem, quinhentos ou mil aeroplanos que despejam bombas, vá o tal sujeito praticar heroísmos! Elle, instinctivamente, appellará para a sabedoria das formigas.

Um publicista inglez, escrevendo para um jornal de Londres, a propósito da 'proxima' guerra, afirmou que ella será tão terrível, tão exterminadora, tão definitiva, que o 'vencedor, exausto, cahirá morto sobre o vencido agonizante'.

Para quem anda com idéas de suicídio, isso tudo é muito interessante...

E quanto ao caracter psychiatrico dos que gostam disso (com excepção dos industriaes de guerra que apenas tratam de cavar a vida á custa da morte dos outros) um jornalista francez publicou há pouco em 'Activités', um estudo muito interessante, no qual ele se refere, justamente, a esse aspecto da questão (...). E Philippe Soupault exclama: 
“Dois aspectos de alienação: mania de grandeza e mania de perseguição”... ${ }^{410}$

Entrecortada por um tom melancólico, essa transcrição evidencia o destino patético da humanidade, encurralada por máquinas assassinas que seus próprios semelhantes determinaram colocar em uso. Observamos que os homens matam, correm, rastejam e se escondem tentando desesperadamente conservar a vida, igualando-se instintivamente aos animais. Os soldados da crônica de Belmonte não demonstram lampejo algum de inteligência. A tecnologia infernal lhes arrancou toda individualidade, todas as qualidades ou ousadias; são números, fazem parte das estatísticas. Eles sequer têm nomes na crônica; são simplesmente "homens” e "sujeito”. Sem nome ou individualidade, eles se colocam em patamar de igualdade com os milhões que existem da sua espécie, mas no pior sentido possível: compõem uma coletividade de despersonalizados.

Os avanços científicos e tecnológicos, criações diletas da razão, foram mostrados pelo avesso: no lugar de oferecerem conforto ao homem, impuseram-lhe a morte, a destruição e o caos. Conforme sugere o último parágrafo transcrito, acompanhado de seu maquinário infernal, o homem tem, pela primeira vez na história, a possibilidade de eliminar toda a sua espécie.

Para Belmonte, o homem do século XX não caminha na direção da felicidade e do progresso. Pelo contrário, na crônica, ele é desclassificado por mais de uma vez. Primeiramente, ele decresce simbolicamente $^{411}$ do nível do leão ao nível do tatu e também é comparado a minhocas e formigas. O escritor praticamente virou a espécie humana pelo avesso, representou-a pelo seu oposto: de poderosas criaturas que têm a capacidade de dominar certas forças da natureza a animais irracionais, insignificantes e rastejantes, quase invisíveis.

A exposição do avesso ou do contrário é apenas uma das estratégias cômicas que Belmonte usa para desencadear o riso em seu leitor. O emprego do absurdo (ou a quebra da lógica) é usado costumeiramente para o mesmo fim. No último parágrafo, por exemplo, vemos uma frase carregada de uma praticidade completamente nonsense: "Para quem anda com idéas de suicídio, isso tudo é muito interessante...”. Ora, quem imaginaria uma ocasião aproveitável para alguém no meio desses horrores? Aprendemos culturalmente a aproveitar-nos de situações que podem ser satisfatórias ou interessantes para a nossa vida, mas jamais para engendrar nosso próprio fim.

\footnotetext{
${ }^{410}$ Cf. Belmonte, A 'próxima’ guerra. Crônica publicada na Folha da Noite (São Paulo) em 05/01/1934, p. 2.

${ }^{411}$ Percebemos que Belmonte representa a psicologia dos soldados por meio de um recurso muito usado na literatura, o símbolo. O leão (o combatente de outrora) é o modelo de força, de beleza e de independência, enquanto que a minhoca é uma criatura que, pelo menos para a cultura ocidental, representa, simbolicamente, a fragilidade, a incapacidade de fazer o mal e, esteticamente, a asquerosidade. Percebemos que, para o nosso autor, os homens regrediram: partindo da altivez leonina, terminaram representados como as minhocas, criaturas viscosas e desprezíveis. Portanto, vemos Belmonte construir o seu discurso usando dois símbolos praticamente opostos em valores: o leão e a minhoca. Cf. Hênio Último Tavares. Teoria Literária. 10ª edição. Rio de Janeiro: Villa Rica Editora, 1974, p. 370-372.
} 
É oportuno observar que, segundo o artista, os soldados de antanho figuravam como heróis, justamente contrapostos aos militares de seu século:

Admitto, para argumentar, que a guerra fosse uma coisa mito interessante, há trinta ou quarenta annos atrás. Até os fins do século passado, as guerras tinham belleza trágica, tinham principalmente heroísmo. Lutar peito a peito, de homem para homem, em combates francos e leaes, era alguma coisa que chegava ás raias da epopéa. Era dramático, mas era bello. Hoje, porém, não há nada disso. A guerra que se desencadeiar agora não virá aureolada de belleza, nem se caracterizará pelo heroísmo. ${ }^{412}$ [grifos nossos]

Ora, as palavras “heroísmo” e “herói” remetem-nos à Odisséia, marco do poema épico extenso, onde o personagem principal (Ulisses, o herói) enfrenta as mais complexas dificuldades e ameaças para alcançar seus objetivos.

Em Estética, livro que abrange um conjunto de estudos de Hegel, obra que serve como referência para pensar tipologias de gêneros literários ${ }^{413}$, assim é definido o herói, cuja gênese, segundo o pensador alemão, remonta à poesia épica grega:

Por isso exigimos, para o livre desenvolvimento do indivíduo (...) um estado no qual a validade da moral assentasse exclusivamente naqueles indivíduos que, graças à sua vontade e à eminente grandeza e eficácia do seu caráter, se acham no posto mais elevado da realidade em que vivem (...). Os heróis são indivíduos que, na independência dos seus sentimentos e vontade individuais, aceitam toda a responsabilidade dos atos que praticam, e que, por virtude do imperativo da sua vontade particular, realizam o que é justo e moral. ${ }^{414}$

O conceito hegeliano é o substrato da visão de herói como um indivíduo quase que sobrehumano, pois portador de qualidades tais como coragem, vontade, honra e justiça. Todavia, ao mesmo tempo, é necessário observar que esse conceito de herói não descarta o uso da violência ${ }^{415}$ pelo mesmo.

\footnotetext{
${ }^{412}$ Cf. Belmonte, A 'próxima' guerra.

${ }^{413}$ Cf. Jaime Ginzburg. Violência e Forma: notas em torno de Benjamin e Adorno. In: http://www.abralic.org.br/enc2007/anais/54/1300.pdf.

${ }^{414}$ Cf. Hegel. Estética - O Belo Artístico ou o Ideal. São Paulo: Abril Cultural, 1974, pp. 236-237.

${ }^{415}$ Cf. Jaime Ginzburg, op. Cit.
} 
Belmonte, profundo conhecedor da literatura brasileira e universal, abordou em sua crônica o "heróico" e a "despersonalização" em termos de possibilitar a comparação da sua atualidade melancólica com o ontem aventureiro (uma situação oposta à outra). Ele encetava essas comparações com o objetivo de tornar sua escrita palatável ao leitor erudito ou não. Nem todos conheciam a ligação do conceito de "herói” com a epopéia Odisséia e a definição do mesmo por Hegel. Mas quase todos sabiam que "herói” era um indivíduo destemido, honrado e inabalável, portador do uso legítimo da violência.

Para Belmonte, os soldados do século XX não têm mais a possibilidade de possuir personalidade ou algum atributo individual notável. São homens totalmente submetidos às máquinas, que, meros números, sequer seriam lembrados como indivíduos. O herói, em contrapartida, é aquele que abandona seu esconderijo para mostrar quem é, para exibir sua individualidade. Assim, ele possui disposição para falar e agir, introduzir-se no mundo e começar uma história própria ${ }^{416}$. O herói é também aquele que, moralmente forte, não se curva à ameaça, resistindo a ela ${ }^{417}$. Ora, nenhuma semelhança com essas atitudes é perceptível nos militares descritos por Belmonte; aflitivamente, eles se apertam, encurralados, em seu lúgubre esconderijo subterrâneo. Os soldados configuram-se em números, assim como os equipamentos bélicos. Mas são estes últimos que parecem se tornar os protagonistas da guerra moderna, e não mais os humanos.

Sugerimos que, para Belmonte, a modernidade figura como um triste período de destruição de todas as possibilidades de livre-iniciativa. É nesse sentido que podemos compreender os soldados despersonalizados das crônicas, completamente submetidos às máquinas. É nesse aspecto que Belmonte lamenta, com um saudosismo irônico, o fato de os combatentes das guerras modernas não terem mais o ímpeto leonino e heróico, independente e ousado de outrora, mas, dominados pelas engenhocas voltadas para o morticínio, assemelharem-se mais a minhocas e formigas. Ademais, a representação belmonteana dos soldados como desumanizados referia-se, provavelmente, ao conhecimento do artista acerca dos estudos psicanalíticos feitos sobre os ex-combatentes da I Guerra Mundial $^{418}$, que indicavam um trauma profundo nas suas personalidades, a ponto de impedi-los de

\footnotetext{
${ }^{416}$ Cf. Hannah Arendt. A Condição Humana. 10ª ed. Rio de Janeiro: Forense Universitária, 2007, p. $198-199$.

417 Cf. Rodrigo Antonio de Paiva Duarte. Adorno, Horkheimer \& A Dialética do Esclarecimento. $2^{\mathrm{a}}$ edição. Rio de Janeiro: Jorge Zahar, 2004, pp. 41-42.

${ }^{418}$ Em Para além do princípio do prazer (1920), Sigmund Freud deteve-se na análise dos ex-combatentes. Segundo ele, uma situação de choque como a que foi vivida por eles (o trauma de estar na guerra e presenciar acontecimentos terríveis) impede a elaboração da vivência traumática pelo ego. Posteriormente, o psicanalista chegaria à conclusão de que era por isso que, na maioria dos casos, os ex-soldados não conseguiam narrar os acontecimentos das trincheiras. Além dos estudos de Freud, em 1918 ocorreu em Budapeste um congresso sobre a psicanálise das neuroses de guerra. Ver Márcio Seligmann-Silva. "Literatura e Trauma: um novo paradigma”. In: O Local da Diferença. Ensaios sobre memória, arte, literatura e tradução. São Paulo: Editora 34, 2000, p. 63-80.
} 
expressarem suas memórias ou vivências. Os ex-soldados permaneciam vivendo quase que como autômatos, e não como homens, pois haviam perdido sua história individual - lembranças e experiências -, um dos aspectos essenciais para a constituição da personalidade. Walter Benjamin, em seu ensaio “O Narrador” (1936), observou que os veteranos voltavam da I Guerra sem a possibilidade de contar histórias. Simplesmente haviam perdido a capacidade humana de narrar. Logo, era como se jamais houvessem existido, pois não podiam transmitir sua experiência de vida para as novas gerações ${ }^{419}$.

Mas a destruição da personalidade dos soldados era sugerida não apenas nos estudos de Sigmund Freud e de outros psicanalistas, mas também na literatura de um ex-combatente alemão. Erich Maria Remarque, veterano alemão da Primeira Guerra, conseguiu, depois de quase uma década, romper a barreira do mutismo e advertir os jovens sobre o aspecto inglório, sem sentido e desumano das guerras, por meio da elaboração de seu livro Nada de novo no Front, publicado em seu país $^{420}$ no final da década de 20. Com a leitura de sua história, percebemos que o impacto psicológico sofrido pelos soldados na guerra causara-lhes uma cisão em suas personalidades, que os impedia de narrar pelo que passaram: as lembranças referentes ao front não eram contadas porque eles achavam que ninguém acreditaria neles, nos horrores que presenciaram; ademais, subjetivamente, eles sentiam uma mescla de orgulho, vergonha e raiva pela profissão de soldado e por terem sobrevivido. Vergonha e raiva porque o acaso lhes poupara a vida, enquanto muitos de seus companheiros de caserna morreram em circunstâncias trágicas. E vergonha, sobretudo, por terem conhecido, na guerra, o patamar mais baixo da condição humana: a alimentação em situações extremamente precárias de higiene, a disputa com ratazanas por restos de comida, a inexistência de asseio e o descontrole sobre seus próprios corpos quando submetidos a intenso tiroteio ou bombardeio. Por causa do pavor, muitos perdiam o controle de suas necessidades fisiológicas, e alguns outros, tomados por uma espécie de surto psicótico repentino, corriam de seus esconderijos e saiam a esmo, sem objetivo, sendo facilmente abatidos pelo exército inimigo.

A outra parte cindida da personalidade dos combatentes é aquela que existia antes da guerra, a do civil. Entretanto, os anos de conflito foram tão traumáticos que eles não conseguiam mais estabelecer uma continuidade de vivência entre o civil que eles foram e a guerra na qual eles lutavam. Era como se duas vidas fragmentadas e incomunicáveis tivessem se apossado de um mesmo corpo.

\footnotetext{
E Belmonte, por sua vez, conhecia algo das teorias psicanalíticas, haja visto que ele empregou em suas crônicas palavras oriundas delas: “mania de perseguição”, “psychiatrico” ( A ‘próxima’ guerra, 05/01/34 e Humorismo, 09/01/1934), “um capítulo de Freud”, “neurose” e “psychose” (Mercedes Simone, 31/10/33).

${ }^{419}$ Ver Walter Benjamin. “O Narrador”. In: Magia e Técnica, Arte e Política. Ensaios sobre literatura e história da cultura. Obras Escolhidas - Volume I, 6a Edição. São Paulo: Brasiliense, 1993, p. 197-198.

${ }^{420}$ Apenas uma rápida observação: apesar do sobrenome francês, Remarque nasceu e cresceu na Alemanha, e lutou por ela na I Guerra. Seus pais tinham ascendência francesa.
} 
Justamente por este fracionamento do eu, a personagem de Erich Maria Remarque, o soldado Paul (Pablo, na tradução em espanhol), não consegue se recordar das emoções e dos pensamentos que, antes da guerra, lhe ocupavam a mente. Quando retorna a casa de seus pais, em uma licença de três semanas concedida pelo exército, ele observa seu quarto, seus livros e tenta se lembrar de sua vida de civil. Não logra sucesso em sua exaustiva tentativa. Suas imagens da infância e adolescência são apenas resquícios de cenas indefinidas:

Quiero que la habitación me hable, que me posea y me lleve, quiero sentir, aquí mi intimidad, quiero escuchar su voz para saber, cuando vuelva al frente, que la guerra es ahogada por la dulce ola del regreso; entonces ya ha pasado; ya no nos carcome; no tiene más poder sobre nosotros que el puramente exterior.

Los lomos de los libros se alinean el uno al lado del otro. Los reconozco todavía y recuerdo cómo los ordené. Les imploro con la mirada: 'Habladme, acogedme; acógeme tú, vida mía de antaño; tú, vida despreocupada y bella, vuelve a poseerme...’ Espero, espero.

Pasan imágenes delante de mí; no me llenan, son tan sólo sombras y recuerdos.

Nada..., nada...

Aumenta mi inquietud.

De pronto surge en mí un terrible sentimiento de extrañeza. No puedo encontrar el pasado. Me rechaza. Es inútil que implore y me esfuerce. Nada vibra. Indiferente y triste, seco como un réprobo mientras se me escapa el pasado. ${ }^{421}$ [grifos nossos]

E Paul não consegue narrar os acontecimentos das trincheiras e dos campos de batalha à mãe, à irmã e especialmente ao seu pai, que insiste incansavelmente. Não lhe é possível colocar em palavras os horrores pelos quais ele passou:

La única que no pregunta es mi madre. Pero mi padre ya es distinto. Él quisiera que yo le contara algo del frente, tiene deseos que me parecen conmovedores y estúpidos a un tiempo. No tengo, ya, con él una verdadera intimidad. Lo que más le hubiera gustado es que me pasase el santo día contando cosas. No se da cuenta de que estas cosas no pueden contarse y me gustaría, por otra parte, darle gusto; sin embargo, sería peligroso, no podría traducir a palabras lo que he pasado; me da miedo de que todo se agigante y que, luego, no me sea posible dominarlo. ¿Dónde estaríamos nosotros si tuviéramos conciencia de lo que sucede allí abajo?

Me limito, por lo tanto, a contarle algunas anécdotas divertidas. Él, no obstante, me pregunta si he tomado parte en algún combate cuerpo a cuerpo. Le digo que no y me levanto para salir.

Sin embargo, no consigo nada con ello." ${ }^{\text {222 }}$ [grifos nossos]

Este jovem de vinte anos já não possui mais memória de sua infância e adolescência e, sobre o passado militar recente, que era o que ele lembrava, estava psiquicamente impossibilitado de falar. Temos, portanto, um rapaz cuja violência exacerbada abalou-lhe a personalidade, cobrindo-a de

\footnotetext{
${ }^{421}$ Erich Maria remarque. Sin novedad em el frente. Barcelona: Printer, s/d, p. 91.

${ }^{422}$ Erich Maria Remarque, op. cit., p. 88.
} 
esquecimentos e silêncio. E Paul não foi um caso particular: os estudos de Freud direcionados aos excombatentes apontavam que essa perda da capacidade de se expressar com palavras e de se recordar foi comum entre eles.

É bastante provável que um exemplar da obra de Erich Maria Remarque tenha caído nas mãos de Belmonte, uma vez que, no início dos anos 30, Nada de novo no front tornou-se largamente conhecido através do filme norte-americano realizado pelo diretor Lewis Milstone ${ }^{423}$ e estreado em vários cinemas da Europa e de países da América do Sul (1931/1932). Concomitantemente, e auxiliado pela notoriedade da sua história por meio das telas, o livro foi traduzido para vinte e cinco idiomas e alcançou uma tiragem de quatro milhões de exemplares, que foram vendidos em poucos meses. $^{424}$

O próprio cronista refere-se muito rapidamente ao livro de Remarque na crônica Os Allemães e a Guerra, publicada na Folha em maio de 1933. Ao comentar sobre o poder da imprensa (da Tríplice Entente e norte-americana), que, durante a Primeira Guerra Mundial, efetuou uma verdadeira desmoralização dos germânicos, ele acrescenta que,

A offensiva que estes paizes realizaram por meio de carapetões sabiamente manipulados, encheu o mundo de um tal sentimento de odio contra a Allemanha que esta, apesar de todos os esforços, acabou mesmo ficando sozinha, e defendeu-se com uma bravura tão épica, que nem Remarque, no seu livro amargo, conseguiu destruir.”425

No Brasil, o filme de Lewis Milstone recebeu o título de Sem novidade no front ocidental, e estreou no cinema Rosário em meados de abril de 1931, sendo passado também nos cines Alhambra, Paratodos e Colyseu até 05 de junho do mesmo ano. No dia 14/05/1931, na página 07 da Folha da Noite, há a informação de que o filme em questão foi recorde de bilheteria em São Paulo. Por meio da página 04 do periódico de 28/05/1931, sabemos que a procura pelo filme na cidade foi tão grande, que há três dias vinham-se registrando brigas nas filas do Colyseu, no Largo do Arouche, e, justamente por isso, mais cinemas paulistanos o projetariam na sua última semana de exibição.

\footnotetext{
${ }^{423}$ O longa-metragem foi produzido em 1930.

${ }^{424}$ Idem, pp. 01-02.

${ }^{425}$ Cf. Belmonte, Os Allemães e a Guerra. Crônica publicada na Folha da Noite (São Paulo) em 29/05/1933, p. 2.
} 
Belmonte, grande admirador da sétima arte, e tendo o cinema como sua diversão preferida e mais frequentada ${ }^{426}$, provavelmente assistiu ao filme. E não apenas isso; sabedor do sucesso que ele fizera, assim como o romance que o inspirou, o esperto cronista aproximou a temática de seus escritos da do filme de Lewis Milstone e da obra de Remarque, procurando assegurar ou ampliar um público leitor para suas crônicas. Ou seja, o artista intentou conquistar novos leitores mesclando suas linhas com a influência de obras de arte que alcançaram muito sucesso em um passado recente: a guerra sob o olhar de horror de Remarque e de Milstone.

A coincidência de idéias do romance alemão com as crônicas sugere-nos que Belmonte conhecia bastante bem a obra de Remarque: há na literatura de ambos a despersonalização e a desumanização impostas aos soldados, um conhecimento detalhado da vida passada sob as trincheiras da Primeira Guerra e as armas empregadas e, como veremos mais adiante, o desvelamento daqueles que incentivavam e desencadeavam os conflitos modernos; ou seja, a quem as guerras modernas interessavam.

O dilaceramento da personalidade nas guerras modernas, presente nos estudos psicanalíticos de Freud, no romance de Erich Maria Remarque e em muitas das crônicas do artista paulistano, não se referiam somente à incapacidade de lembrar ou narrar dos soldados. Diziam respeito também à sujeição dos seres humanos à potência e engenhosidade das máquinas. Na crônica A próxima guerra $^{427}$, de 27/11/1933, Belmonte salienta que os inventos científicos e tecnológicos podem ser usados para dinamizar e facilitar o trabalho humano, mas também para a destruição da humanidade. O problema é que os inclementes países imperialistas e as grandes indústrias bélicas impelem, sem titubear, os homens para a carnificina. Manipulados por essas entidades poderosas, os seres humanos se vêem às portas de um novo e terrível conflito de largas proporções.

O escritor inicia sua crônica sublinhando a opção assassina das "usinas". Um dos seus cientistas (Barlow) criou um raio que, segundo o artista, poderia ser usado para auxiliar na construção de cidades e em muitas outras obras. No entanto, ele foi escolhido pela indústria e pelos estadistas justamente como arma de ameaça e eliminação. Esta escrita de Belmonte é, assim como de costume, entrecortada por excelentes sátiras e ironia:

Enquanto a Conferencia do Desarmamento vae se arrastando rheumaticamente, com todas as apparencias de accabar em nada, as usinas bellicas e os laboratórios chimicos

\footnotetext{
${ }^{426}$ Conforme comentários que emergem de alguns de seus escritos e da crônica publicada no seu livro Assim falou Juca Pato (aspectos divertidos de uma confusão dramática): "Um homem sensacional”, pp. 64-67.

${ }^{427}$ A crônica de 05/01/1934, A 'proxima' guerra, é quase homônima dela, diferenciando-se apenas pelas aspas.
} 
vão proseguindo nos seus trabalhinhos sinistros de inventar coisas arripiantes para liquidar o próximo com todos os éffes e érres .

Ainda agora apparece um tal senhor Barlow querendo levar ao conhecimento da Conferencia a noticia official de um seu invento, um 'raio que o parta' terrível, capaz de pôr abaixo, em dois minutos, qualquer cidade, num raio de mil e quinhentos kilometros.

Já escrevi uma vez sobre essas descobertas fantásticas e tive a sinceridade de não leval-as á serio porque, até agora, ninguém viu experiência nenhuma desse genero. Se se póde, com um raio, destruir uma cidade, é claro que, com esse mesmo raio, se poderia desmoronar uma montanha. Entretanto, quando se pretende pôr abaixo um morro, gastam-se annos e annos nesse trabalho cyclopico, com despesas fabulosas. Não seria, pois, mais pratico, intelligente e econômico sapecar um raio desses para cima da montanha e pôr tudo abaixo num abrir e fechar de olhos?

Seria. Entretanto, todos esses fantásticos inventores se fecham em copas, allegando que a sua invenção é tão terrível, tão monstruosa, tão deshumana, que elle pretende guardal-a em segredo, usando-a apenas no caso do seu paiz ser aggredido.

E é ahí que está a sabedoria desses homens. Elles pretendem, com isso, obrigar todo o mundo a respeitar a sua pátria, livrando-a dos perigos de aventuras imperialistas, $e$ com o beneplácito e interesse de seus estadistas. ${ }^{428}$ [grifos nossos]

Todas as convenções humanas apresentam-se em desordem, de "pernas para o ar": a ciência trabalha para o aperfeiçoamento das armas de guerra e defende sua produção por meio do discurso de que elas são fabricadas para “causar medo” nos países e, com isso, evitar conflitos; o cientista Barlow deseja informar à Conferência do Desarmamento da criação de seu terrível raio mortífero, sendo esta comunicação em si um contra-senso, porque totalmente oposta aos objetivos da conferência - ainda que ela se encontre anciã, moribunda, "rheumática".

Os cientistas, por sua vez, configuram-se como aliados das indústrias de guerra, estando elas e os Estados imperialistas focados somente em adquirir territórios e capital. E para conquistá-los, não vêem grandes problemas em ir até as últimas conseqüências, ou seja, até a guerra tão anunciada e temida:

${ }^{428}$ Belmonte, A próxima guerra. Crônica publicada na Folha da Noite (São Paulo) em 27/11/1933, p. 2. 
Não acredito nesses raios. O único em que creio, não por tel-o visto, mas por ter tido, delle, um conhecimento que seria infantil fingir ignorar, é a onda super-curta de Marconi que não sendo, propriamente, um raio mortífero, póde ser 'aperfeiçoado' nesse sentido. Não estranhem o 'aperfeiçoamento' porque neste mundo supercivilizado a perfeição é isso mesmo: liquidação summária.

O mesmo, porem, não acontece com os gazes, cuja aç̧ão destruidora vae indo em progressos assustadores. E as armas offensivas, como o torpedo imantado e outros animaes ferozes, além das culturas microbianas - tudo isso está se mobilizando para o próximo charivari mundial, charivari que parece inevitável, pois ainda há poucos dias o 'Sunday Mirror’ publicou um artigo tremendo com este título tremendíssimo: 'Our next war'.

Nesse ponto eu estou com o bravo general Góes Monteiro: a guerra é necessária, indispensável, divina. É preciso que ella se desencadeie logo para acabar de uma vez com o mundo que, com as suas maluquices, anda envergonhando o systema planetário.” ${ }^{429}$ [grifos nossos]

Nestas linhas que portam um misto de amargura e humor, observa-se que a civilização moderna traiu por completo seus ideais: em lugar de favorecer o acesso de todos os seres humanos à instrução, à participação política e ao trabalho, ela se empenha na "liquidação summária” de parte significativa da humanidade, algo na cifra de milhões.

Belmonte mostra-se inconformado com a trajetória humana. Depois de discorrer sobre as atitudes irracionais e criminosas adotadas por seus semelhantes, ele confessa, não sem jocosidade, que até as exaltações ao belicismo de Góes Monteiro lhe parecem, agora, mais aceitáveis, posto que uma guerra tremenda seria a única forma de extinguir a humanidade e sua crueldade incontrolável. Perante uma realidade desoladora e impossível de ser mudada, a melancolia novamente se faz presente na literatura belmonteana. Frequentemente, o escritor acusa a perda da razão pela humanidade, configurando-a como louca, “doida varrida”, vítima de um surto coletivo. Aqui, ela envergonha o “systema planetário” com suas “maluquices”. Numa crônica, Belmonte comenta que nenhum psiquiatra conseguirá endireitá-la. Em outras, os insanos mais perigosos são aqueles que estão para fora dos muros do "Juquery”.

Não é para menos; é absolutamente ilógico imaginar que o homem, a única criatura racional deste mundo, use sua produção científica para massacrar sua própria espécie! Ademais, os

${ }^{429}$ Idem, ibidem. 
incentivadores/propulsores dos assassinatos em massa configuram-se numa minoria apenas, mas é ela que conduz o trágico percurso da desventurada humanidade.

Eis os inimigos dos homens comuns apontados por Belmonte: os dirigentes dos Estados, os donos e acionistas das empresas bélicas (“as usinas bellicas”) e a alta hierarquia militar (alusão a Góes Monteiro, no plano nacional). Esta visão é muito semelhante com aquela colocada pelo pacifista Erich Maria Remarque. Em uma passagem do capítulo nove de Nada de novo no front, enquanto vários soldados conversam, um deles, de nome Tjaden, questiona-os sobre a quem as guerras interessam. Ele garante que os soldados rasos não estão ganhando nada com o conflito, e aposta que os franceses do outro lado da trincheira também não. Após algum tempo de reflexão, os jovens chegam à conclusão que ela interessa aos Estados, aos generais, possivelmente ao Kaiser e àquelas pessoas que ficam ricas às custas da belicosidade; trocando em miúdos, os comerciantes, que, de algum modo, açambarcam os produtos de primeira necessidade e os proprietários anônimos das indústrias de armamentos.

Artistas e intelectuais pacifistas mostravam-se críticos em relação ao discurso xenófobo de alguns Estados europeus. Nesse sentido, o problema para eles não se centrava em algum "povo" específico. Pelo contrário, procuravam revelar que tanto na Alemanha, como na França, e como em qualquer outro país, havia pessoas laboriosas, responsáveis e habitualmente boas, e que tinham em comum o cotidiano de uma vida voltada ao trabalho.

Temos, nessa direção, as palavras de Erich Remarque, quando narra um dos argumentos de Tjaden: “...sin embargo, piensa que la mayoría de nosotros somos gentes sencillas. Y, en Francia casi todos los hombres son, también, obreros, peones o pequeños empleados. ¿Cómo puede querer atacarnos un zapatero o un cerrajero francés?”430

Com o sucesso de seu romance e do filme baseado nele, Erich Maria Remarque tornou-se famoso, e sua história semi-autobiográfica materializou-se em um dos libelos preferidos dos pacifistas de todo o mundo. Os pacifistas do entreguerras, dentre os quais destacavam-se os ilustres cientistas Albert Einstein e Sigmund Freud ${ }^{431}$ e os notáveis escritores Henri Barbusse, Max Gorki e Romain Rolland, buscavam esclarecer a quem as guerras interessavam. E todos eles possuíam um discurso próximo daquele manifestado na literatura de Remarque: a humanidade estava sendo

\footnotetext{
${ }^{430}$ Cf. Erich Maria Remarque, op. Cit., pp. 107-108.

${ }^{431}$ Entre 1932 e 1933, Einstein e Freud trocaram cartas onde frisaram seu pacifismo. Procuraram, também, refletir por que as guerras se repetiam e por que os seres humanos se inclinavam tão facilmente à destruição.

Cf. Sigmund Freud et Albert Einstein, Pourquoi la guerre?Correspondence entre Albert Einstein et Sigmund Freud. Trata-se da versão editada por meio da iniciativa do Instituto Internacional de Cooperação Intelectual. Sociedade das Nações, 1933. In: http://classiques.uqac.ca/classiques/freud_sigmund/freud.html
} 
manipulada e ludibriada pelos Estados e pelas indústrias de armas, que obedeciam a uma lógica imperialista e de acumulação de capital. Logo, parece evidente que Belmonte estava bastante bem informado do discurso pacifista internacional, disseminando-o com constância através de seus escritos. E ele sabia quem eram os inimigos das guerras, colocando seus leitores a par de suas ponderações e opiniões:

Acabo de ler numa revista européia uma 'enquete’ que, realizada em outros tempos, causaria pasmo ou indignação, mas que levada a effeito nesta época absurda e paradoxal, é tida como a coisa mais natural e innocente deste mundo. A pergunta exquisita que a revista fez a várias personalidades de renome internacional foi esta: 'Está o mundo ameaçado de uma nova guerra'?

A simples interrogação vale por uma affirmativa. Ninguém se atreveria a fazer semelhante pergunta a vários homens illustres se a guerra não fosse mais que uma ameaça.

Foram consultados e responderam á 'enquete' os escriptores Maximo Gorki, Henri Barbusse, Romain Rolland, Karin Michaelis, Andersen-Nexö, Heinrich Mann, o scientista Einstein, o sociólogo japonês Katayama e o político hindu Valabhay Patel. Maximo Gorki acha que a guerra é inevitável. As fábricas de armamento e munições, as grandes usinas béllicas em espantosa actividade são, para o grande escriptor russo, a causa principal do momento de angustia que a humanidade está passando, $e$ são os fabricantes de armas os fomentadores da terrível conflagração que nos ameaça.

Até ahí morreu o Neves. Que são esses cidadãos que andam fomentando guerras $e$ creando casos, já é facto mais que sabido. Tanto que Barbusse, respondendo á 'enquete', é da mesma opinião. E Einstein também. Os armamentistas, industriaes, capitalistas e outros animaes ferozes da industria de guerra não se limitam a fabricar armas e a vendel-as. Mettem-se pela política, insinuam-se na diplomacia, sustentam jornaes, enfim, armam uma teia tão resistente que o coitado do povo cáe e não mais escapa do aranhol tremendo.

Romain Rolland e Karin Michaelis attiram a culpa da futura guerra nas costas do fascismo. Este, com seu ultra-nacionalismo, vivendo dentro de suas fronteiras e fechando-as para a cooperação alienígena assume a todo momento, com essa política de portas fechadas, atitudes de quase hostilidade para com os vizinhos. Dahí é que começam os bate-boccas. E do bate-bocca para o 'péga', a distância é bem pequena. Enfim, seja por culpa do capitalismo ou do fascismo, o certo é que a 'próxima guerra' 
surge como uma coisa fatal, inevitável. (...) Mas - dir-se-á - é preciso, então, que alguém comece atacando.

Ahí é que está o grande problema. Mas bastará apparecer um maluco na rua e berrar: MORRA FULANO!

E lá se irá tudo o quanto Martha fiou!

Era uma vez a Europa... ${ }^{432}$ [grifos nossos]

Há nas crônicas, no romance de Remarque e nas correspondências trocadas entre Sigmund Freud e Albert Einstein, inúmeras observações sobre o conflituoso período histórico de então. Subentende-se que a fabricação das indústrias bélicas (organizadas em monopólios ou oligopólios) encontra um aliado e financiador de peso na figura do Estado nacional. Tendo em comum o interesse na produção de artefatos militares, ambas as organizações se aproximam. A partir da segunda metade do século XIX, conforme as palavras de Eric Hobsbawm,

(...) Ocorreu a fusão da rivalidade política entre os Estados [sobretudo os europeus] com a concorrência econômica entre grupos nacionais de empresários, o que contribuiu - como veremos - tanto para o fenômeno do imperialismo como para a gênese da Primeira Guerra Mundial. Levaram também, a propósito, ao crescimento de industrias em que, como na industria bélica, o papel do governo era decisivo. ${ }^{433}$

Se em muitas de suas crônicas o autor desprestigia sistematicamente a humanidade, apontando-na como “doida varrida”, na crônica Esterilização, de 28/12/1933, a opinião de Belmonte sobre ela é ainda mais desoladora. Segundo o escritor, os homens realizaram tantos erros que conseguiram esfacelar a sua própria organização social. E a provável eclosão de um novo conflito ameaça a humanidade incessantemente. Logo, Belmonte propõe a esterilização de todos os seres humanos, de sorte que não seria necessária uma nova guerra para acabar com eles. Se a "lógica” humana parece limitada à eliminação ou ao não-existir, a esterilização alcançará o mesmo resultado, só que mais suavemente - ainda que demore mais tempo -, assegura-nos o escritor.

O assunto é iniciado quando Belmonte se propõe a comentar a opinião de Fernando Magalhães (notório médico e professor fluminense) ${ }^{434}$, propalada pela imprensa. O grande

\footnotetext{
${ }^{432}$ Belmonte, Uma nova guerra? Crônica publicada na Folha da Noite (São Paulo) em 11/11/1932, p. 2.

433 Cf. Eric J. Hobsbawm. A Era dos Impérios (1875-1914). 8 a edição. São Paulo: Paz e Terra, 2003, p. 84.

${ }^{434}$ Fernando Augusto Ribeiro Magalhães atuou como médico, professor e político. Nasceu no Rio de Janeiro em 18 de fevereiro de 1878, e faleceu na mesma cidade em janeiro de 1944. Depois de se bacharelar em ciências e letras pelo
} 
especialista em obstetrícia e ginecologia criticara enfaticamente a decisão dos nazistas, que almejavam esterilizar os “doentes incuráveis”, os esquizofrênicos e os criminosos. Foi a concepção do médico brasileiro, de que todas as doenças e desvios humanos são passíveis de tratamento, que o fez se posicionar contra a resolução dos hitleristas alemães.

Inesperada e aturdidamente para o leitor freqüente de suas crônicas, aquele que já tinha familiaridade com as suas idéias políticas, Belmonte se pronuncia a favor desta decisão nazista. Mas, com sua zombaria habitual, ele reformula a proposta germânica e a recoloca, propugnando a esterilização de todos os seres humanos, de modo que, dali a algumas décadas, os homens considerados "normais" não mais estariam no mundo para declarar guerras, fabricar armas e exterminar seus semelhantes.

Ora, apesar de eu não ser scientista, peço humildemente licença para entrar no debate e dar minha abalizada opinião sobre o assumpto.

Assim, pois, biologicamente falando, estou de inteiro, absoluto e formal accôrdo com o decreto nazista da esterilização dos anormaes e dos incuráveis. Dispenso-me de entrar em detalhes scientificos, forrando-me ao trabalho innocuo de apresentar uma these solene sobre o grave problema de diminuir a espécie. Não me interessam, de momento, os psychopatas, nem os leprosos em ultimo grau, nem os lombrosianos. Isso é com os homens de sciência, que podem saber até que ponto o filho de louco varrido póde viver ás custas do pae, mesmo sem a tara paterna. Se, como faz suppor o senhor Fernando Magalhães, a theoria da hereditariedade é um blefe que ninguém pode levar a sério, e os incuráveis podem ser curados para trabalhar pela prole, então a esterilização seria uma coisa monstruosa. A verdade, porém, é muito outra. ${ }^{435}$ [grifos nossos]

Belmonte não perdeu a oportunidade de fazer propaganda de seu livro, Assim falou Juca Pato, que contêm uma crônica ${ }^{436}$ cuja temática se aproxima de Esterilização. Ele aproveita igualmente para

Colégio Pedro II, doutorou-se na Faculdade de Medicina do Rio de Janeiro, em 1899. Ali passou a dar aulas como professor de Clínica Ginecológica e Obstétrica, em 1900-1901; livre docente de Obstetrícia, de 1901 a 1910; professor de Clínica Obstétrica, de 1911 a 1915; diretor do Hospital da Maternidade do Rio de Janeiro, de 1915 a 1918; catedrático de Clínica Obstétrica, em 1922. Foi diretor da Faculdade de Medicina, em 1930; reitor da Universidade do Rio de Janeiro, em 1913. Teve, também, atuação na política nacional, como deputado do Estado do Rio de Janeiro à Constituinte em 1934 e pelo Distrito Federal ao Congresso Nacional em 1937.

${ }^{435}$ Belmonte, Esterilização. Crônica publicada na Folha da Noite (São Paulo) em 28/12/1933, p. 2.

${ }^{436}$ Belmonte. Super-Malthusianismo. In: Assim falou Juca Pato (aspectos divertidos de uma confusão dramática). São Paulo: Companhia Editora Nacional, 1933, p.240-242. 
ironizar sua própria produção humorística cética e desalentadora, e também seu leitor, ao propor-lhe a compra de sua obra para dar de presente nas festas da passagem de ano (1933-1934):

\begin{abstract}
No meu livro ‘Assim falou Juca Pato’ (o senhor já comprou um exemplar para dar de ‘festas' no dia 31?) eu tratei exhaustivamente desse caso singular, lançando a minha doutrina super-malthusiana, com a esterilização, não dos enfermos e psychopatas apenas, mas de toda a humanidade. ${ }^{437}$
\end{abstract}

Seria ela um "bom auspício” para o ano-bom? Talvez não, mas tudo bem, pois combina com ele; ao fim, o "novo” sempre se revela, melancolicamente, uma enganação, frustrando as esperanças dos homens comuns. Logo, sem conseguir entrever soluções eficazes para os graves problemas humanos, o que há de melhor para fazer é rir amargamente da desventura de si próprio e dos outros.

O artista se confessa despreocupado ou ignorante com relação à possibilidade de recuperação dos chamados “doentes incuráveis”:

Não me interessam, de momento, os psychopatas, nem os leprosos em ultimo grau, nem os lombrosianos. Isso é com os homens de sciência, que podem saber até que ponto o filho de louco varrido póde viver ás custas do pae, mesmo sem a tara paterna. $^{438}$

Mas ele tem absoluta certeza de algo: de que a irracionalidade e a estupidez dos seres humanos "normais” não têm mais solução. Uma situação é o indivíduo perder a sanidade e/ou a capacidade de raciocínio. Outra completamente diferente é o indivíduo optar pela destruição e eliminação de outro(s), sendo que, não raramente, ele faz as vezes do carrasco:

Com effeito, os senhores já reflectiram bem no mystério da vida? Para que se nasce? Qual a utilidade da existência?

Num tempo destes em que a luta pela vida é um verdadeiro círculo dantesco, e o futuro é uma super-dolorosa interrogação, negra e trágica, os senhores acham

\footnotetext{
${ }^{437}$ Idem.

438 Idem.
} 
natural, acham razoável, acham humano encher o mundo de filhos para...Para que? Que é que os espera mais tarde? Para onde vamos e para onde irão elles?

A humanidade falliu. Observem que, quanto mais se procura conservar esta bola de lama, mais ella apodrece. Abram os jornais e leiam as noticias de todos os dias: suicídios, assassinatos, parricídios, desastres, catastrophes, desordens, motins, rebelliões, guerras, conflagrações, seccas, tufões, naufrágios... Um pandemônio apocalyptico! Está tudo errado, tudo virado pelo avesso, de pernas para o ar. Fala-se em guerra como sendo a coisa mais natural deste mundo! Os povos se entendem cada vez menos, as mulheres andam de calças, o sr. Getúlio candidata-se para a presidência da República, o sr. Juarez Távora diz que a Constituinte é uma casa em construcção e, como se tudo isso fosse pouco, ainda há homens que jogam yô-yô...

Ora, os senhores não acham que é uma deshumanidade a gente crear filhos para atirar nesse Juquery universal? (...) Ora, diante disso, só há uma solução: esterilização geral! Ninguém nasce mais!

E, assim, suavemente, dentro de quarenta ou cincoenta annos o mundo se acabará por falta de gente.

Ficarão apenas os animaes. Mas esses têm juízo e talvez consigam endireitar este mundo que nós fizemos tudo para estragar... ${ }^{439}$ [grifos nossos]

Estas linhas chamam os leitores para refletirem sobre a existência humana. Em um mundo completamente instável, imprevisível, virado pelo avesso (por exemplo, as afirmações satíricas: “...as mulheres andam de calças...”, “...o sr. Getúlio candidata-se para a presidência da República...”, e, ainda por cima, “...há homens que jogam yô-yô”) e ameaçado por conflitos de proporções possivelmente inéditas, põe-se nas entrelinhas a seguinte questão: conseguirão os casais saudáveis, “normais”, garantir o bem-estar e a felicidade de seus filhos? Ou será que esta impossibilidade se expande para além dos doentes “incuráveis”? Percebe-se que a ameaça ao bem-estar das famílias não se concentra “apenas” na perspectiva de uma nova guerra, mas também na miséria material advinda do avantajado número de desempregados da década de trinta:

Na Europa, os estudantes das Universidades fazem esforços inauditos - não para se formarem - mas exactamente para serem reprovados. Porque, enquanto estudam, os

${ }^{439}$ Belmonte, Esterilização. Crônica publicada na Folha da Noite (São Paulo) em 28/12/1933, p. 2. 
paes os sustentam, bem ou mal. Mas logo que se formam são promovidos a 'chômeurs'. Ficam annos e annos 'no desvio'... ${ }^{440}$

Belmonte afirma, enfaticamente, que a humanidade faliu, construiu um apavorante "Juquery" universal. Portanto, ela nada mais tem a oferecer às novas gerações além da certeza da miséria, da violência e da morte. A posição do artista é, sem dúvida, de profunda desilusão com o homem e de descrença nas sociedades humanas. E esta posição é construída com argumentos sustentados na razão. Nesse sentido, a proposta de gerar novas vidas configura-se numa insensatez absoluta.

E a humanidade faliu, justamente, por se recusar a seguir os preceitos da razão, entregando seu destino nas mãos de políticos e empresários bélicos cujos objetivos imperialistas e de concentração crescente de capital encontravam-se na contramão da felicidade da maior parte dos homens e mulheres que viviam sobre o planeta.

É hilariante observar que Belmonte publicou este escrito a apenas três dias do ano-novo (28/12/1933). Ao se opor àquilo que seria mais previsível ou lógico para aquela data, como, por exemplo, uma crônica esperançosa e/ou de humor leve, o humorista virou tudo pelo avesso... Simbolicamente, se o ano-novo era (e ainda é) costumeiramente representado por uma criança, ele o contrapôs com a sugestão de pôr a termo a possibilidade de se gerar novas existências humanas.

A defesa da esterilização ${ }^{441}$ na crônica de Belmonte é impressionante, mesmo se tratando de uma literatura humorística. Afinal, estamos discorrendo sobre uma época em que o principal objetivo feminino, incutido nas meninas e moças pela Igreja (e por sua família), era se preparar para, no futuro, poder zelar pelo bem-estar de seu esposo e se dedicar à criação dos filhos. O próprio catolicismo incentivava ostensivamente a maternidade nos limites do casamento, repetindo o famoso ensinamento do Evangelho: “Crescei e multiplicai-vos”. E, naqueles idos dos anos 30, quando a maior parte da população brasileira identificava-se como católica, a crônica Esterilização surgia como bastante ousada, própria de uma mente livre de dogmas religiosos. E em uma outra crônica, Ainda a Esterilização, de 02 de janeiro de 1934, Belmonte volta ao mesmo assunto e afirma que, apesar dos eclesiásticos incentivarem a procriação, silenciosa e privadamente, eles estavam de acordo com suas idéias; tanto isso era verdade que nenhum deles era pai.

\footnotetext{
${ }^{440}$ Idem, ibidem.

${ }^{441}$ Este assunto está presente e é defendido em outras crônicas, como, por exemplo, Na tal idade, de 31/05/1933.
} 


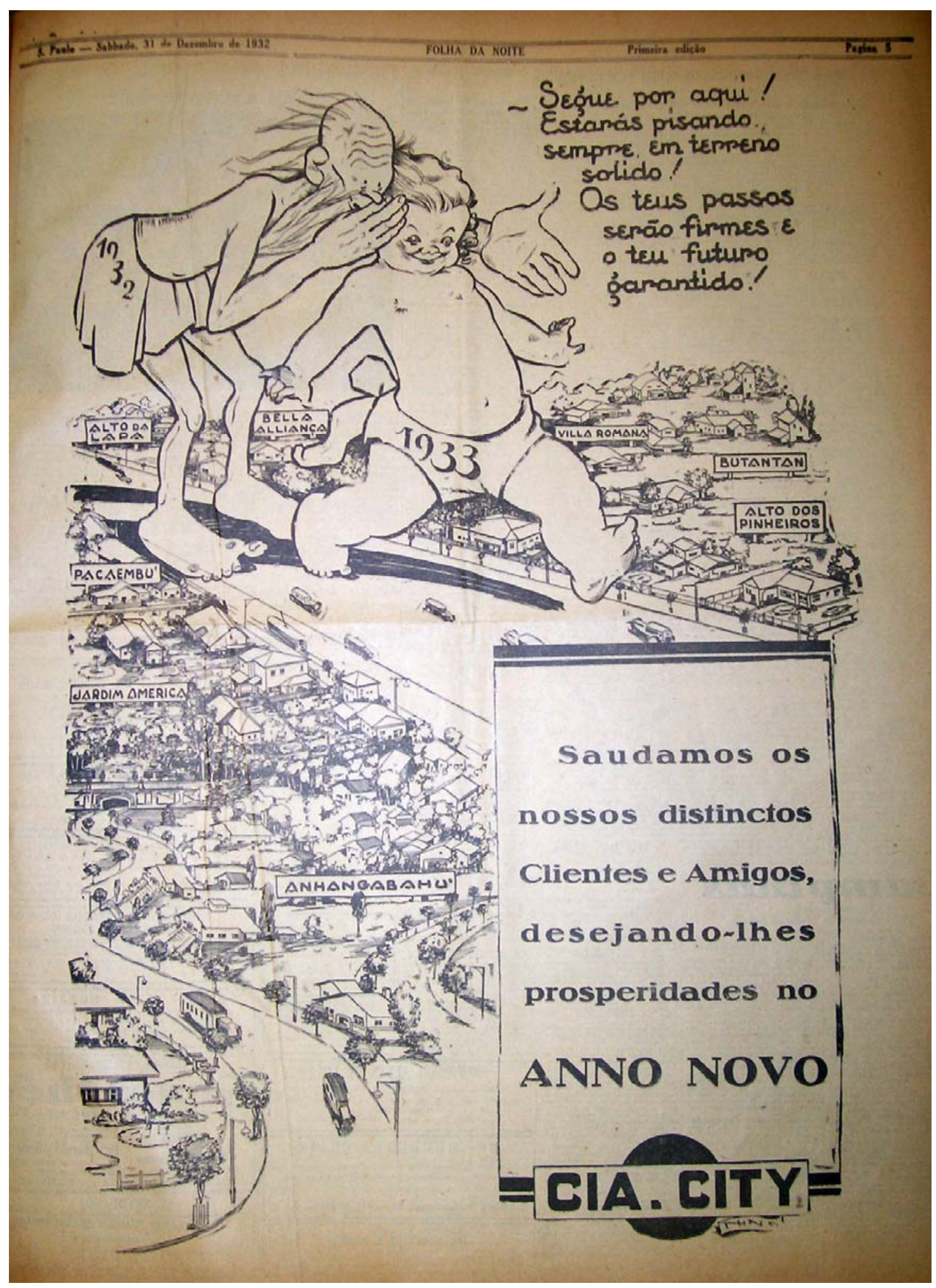

Fig. 18. Propaganda da Companhia City.

Folha da Noite (São Paulo), 31/12/1932, p. 5.

Hemeroteca do Arquivo da Folha de São Paulo. 
Esterilização impressiona, indubitavelmente, pelos problemas humanos relatados nela, sendo que parcela considerável deles parece, ainda para os dias de hoje, muito atual: as crises econômicas do capitalismo, as guerras, a violência e a disseminação do desemprego, que tinha se tornado algo corriqueiro. Se excluíssemos o nome de algumas personalidades públicas e regimes políticos datados, no caso de Juarez Távora, Getúlio Vargas, Adolf Hitler e o Nazismo à frente do governo alemão, parte das críticas deste escrito poderia se referir ao princípio do século XXI.

No entanto, por mais que tenhamos nos impressionado com o humanismo de Belmonte em suas críticas contra o autoritarismo e a modernização conservadora, presentes na maior parte de suas crônicas, não podemos deixar de reconhecer que emerge das linhas de Esterilização um posicionamento derrotista. Afinal, sugerir o encerramento da perpetuação da espécie humana seria impossibilitar a tentativa de se construir uma outra história, sem miséria e violência exacerbada. Seria eliminar, definitivamente, todas e quaisquer esperanças. E esse derrotismo, por negar qualquer possibilidade de melhora à trajetória humana, mal encobre um pensamento algo conservador.

Nesse sentido, o cronista que se insinuava nas entrelinhas como o arauto da razão e da lógica contra a irracionalidade humana, tropeçou em suas próprias palavras. O humorista, de tanto que girou a sua arguta arma da escrita, aparentemente perdeu o controle sobre ela e a viu, repentinamente, apontada para sua própria cabeça, o que demonstra a força da produção literária superando a mera expressão de uma subjetividade: sua capacidade crítica atingia, inclusive, o autor. Observemos que o pensamento de Belmonte atribuiu ao uso da razão, nesta crônica, um caráter estritamente utilitarista, instrumental, visando apenas a um fim, justamente aquilo que ele tanto criticara na maior parte de suas crônicas voltadas para o Nazi-fascismo e a modernidade: se a humanidade não consegue alcançar a melhora de si mesma, se “não dá certo”, então é preferível que ela deixe de existir.

Entretanto, não podemos pensar essa pessimista produção cultural descontextualizada de seu período de feitura e das idéias de seu autor. Naqueles instáveis e conflituosos anos 30, em que muitas democracias liberais foram derrubadas por regimes autoritários, temos na crônica a visão de um liberal que, ao observar a derrocada delas e o declínio progressivo de outras, desconfiando das ideologias de esquerda e tendo aversão às ascendentes ditaduras de direita, desolado, viu diante de si um panorama político brasileiro e europeu sem perspectiva alguma. E o efeito de angústia que se produzia no leitor tinha um alcance crítico que podia ir além de pessimismo ou depressão. 


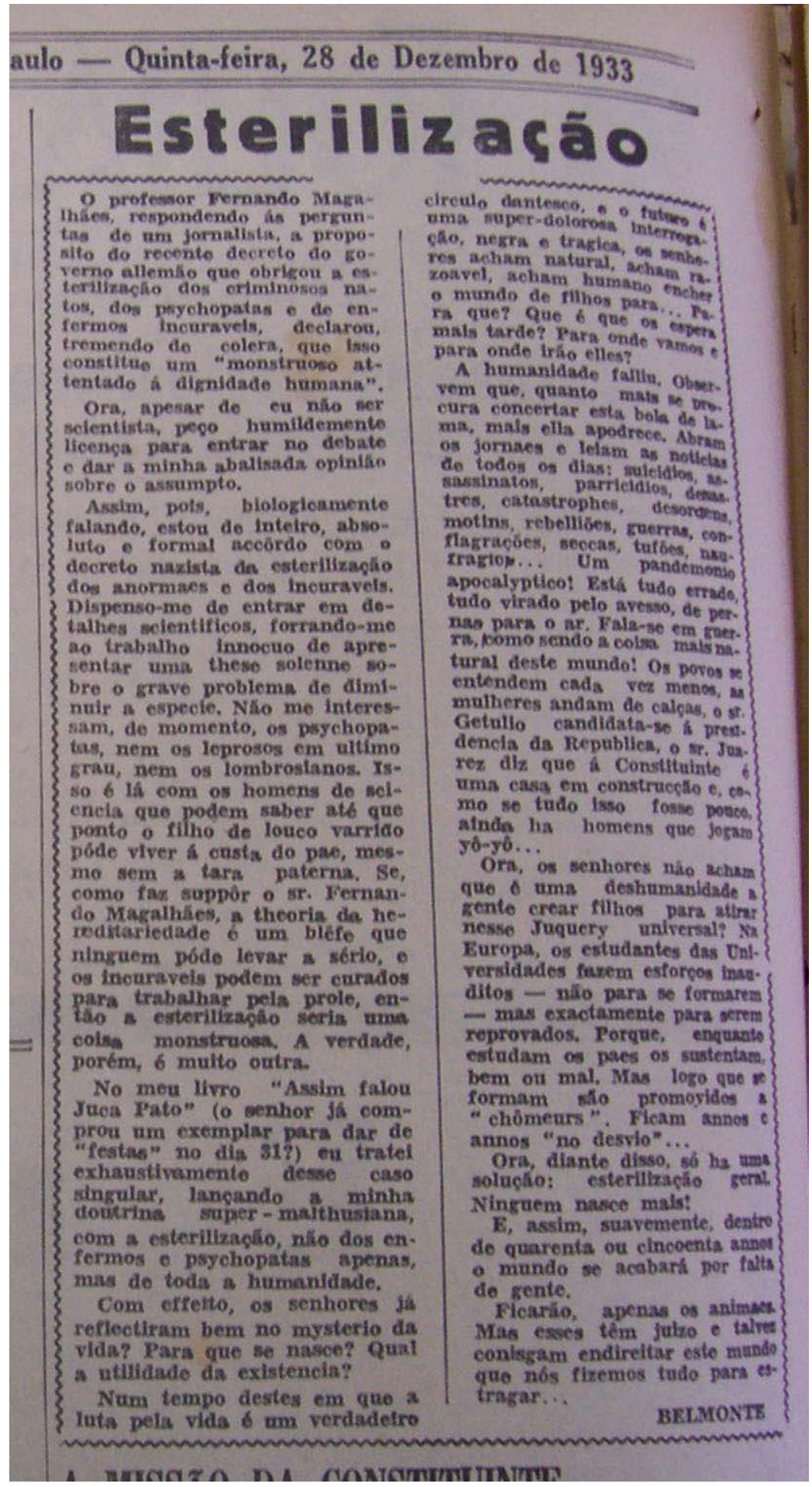

Fig. 19. Esterilização. BELMONTE.

Folha da Noite (São Paulo), 28/12/1933, p. 2.

Hemeroteca do Arquivo do Estado de São Paulo - AE/SP. 
De qualquer modo, percebe-se que, para Belmonte, a modernidade e seu desenvolvimento científico e técnico se configuraram no avesso daquilo que foi propugnado pelo pensamento ilustrado e iluminista. O artista acusa a ascensão de uma modernidade desviada de seus ideais, repressiva, dominadora, que dispõe dos homens como se eles fossem bonecos inanimados. Diante dela, os ideais de liberdade e democracia tornam-se profundamente abstratos, se não impossíveis, sendo a fragilidade deles reafirmada com constância nas crônicas.

Nesse sentido, o escritor salienta alguns dos desconfortos profundos que perpassam toda a sociedade ocidental. Alerta que certos aspectos de sua organização estão evidentemente errados e que eles impedem a realização de uma modernidade voltada para o bem-estar humano. E estes aspectos problemáticos configuravam-se no apego ao poder político e econômico, e na extraordinária concentração de renda, que à época era representada principalmente pelos monopólios e oligopólios.

Todavia, se Belmonte foi perspicaz ao detectar e expressar algo do mal-estar que imperava nas sociedades capitalistas, ele jamais criticou de maneira formal e com maior ênfase o sistema capitalista em si. Seguramente, porque um jornal liberal como a Folha da Noite não toleraria este tipo de posicionamento de um colaborador seu. Além do mais, é possível que a crítica ao sistema capitalista, concomitante à defesa do pacifismo, poderia despertar suspeitas de que talvez o artista fosse simpático ao Comunismo; afinal, à época, a crítica ao Capitalismo e o repúdio ao imperialismo eram duas características marcantes nos comunistas.

Podemos pensar também - e esta provavelmente é a sugestão mais correta - que, devido a trajetória pessoal de Belmonte (de apoio ao Partido Democrático em um passado próximo e de simpatia aos princípios liberais), uma crítica mais incisiva e explícita com relação à sociedade capitalista simplesmente lhe parecia fora de questão. De forma indireta, todavia, essa crítica findou emergindo em seus escritos.

Mas, ainda que a $1^{\text {a }}$ Guerra Mundial tenha se configurado em um grande choque para as pessoas do período, justamente por marcar uma brusca e traumática mudança no emprego da tecnologia, e o “crack” de 1929 tenha abalado sensivelmente a confiança no progresso, a concepção negativa de Belmonte sobre a modernidade, especialmente com relação à modernidade técnica, deve também ser procurada em solo brasileiro, mais especificamente nas terras de São Paulo, em seu crescimento e desenvolvimento incessantes e no desenrolar de conflitos político-militares referentes a essa região do país. Vejamos, primeiramente, o desenvolvimento contínuo da capital de São Paulo nas primeiras décadas do século passado. 
Desde fins do século XIX, a cidade crescia a olhos vistos. Entre 1920 e 1934, sua população praticamente dobrou de tamanho; de 500.000 moradores, ela atingiu a marca dos $1.000 .000^{442}$. A produção industrial também se desenvolvia a passos largos. Já em 1935, a capital paulista tinha 58\% das indústrias, empregava 56\% dos operários e proporcionava $61,5 \%$ do valor da produção do estado. Sua produção industrial superou a da cidade do Rio de Janeiro na década de $30^{443}$.

Ainda que os moradores da cidade se impressionassem com o seu rápido desenvolvimento e sentissem orgulho do dinamismo da mesma, a modernização da urbe era, em contrapartida, bastante desconfortável: tinha-se a impressão de que ela estava completamente descaracterizada, e simplesmente não se conseguia mais apreendê-la. Construções, demolições e alargamento de pistas eram realizados com uma velocidade inusitada: a absoluta instabilidade era a marca de São Paulo. Além do mais, seu crescimento humano não foi acompanhado eqüitativamente pelo fornecimento dos serviços de água encanada, esgoto, luz elétrica, transporte e recolhimento de lixo ${ }^{444}$. Logo, a improvisação e a desorganização passaram a ser características inerentes da cidade.

Algumas crônicas se mostraram muito críticas com relação ao transporte público oferecido aos paulistanos, cuja concessão da prefeitura de São Paulo privilegiou a empresa Light, que monopolizou o serviço de bondes. Belmonte aponta o péssimo serviço prestado por ela, que mantinha as tarifas caras e poucos “camarões” em circulação, acarretando longas esperas e superlotação nos veículos. Estes contratempos estão presentes nos escritos Podia ser péor, de 31/10/1934, e em O drama dos jardinenses, de 28/11/1934, entre outros.

A Light monopolizava igualmente a prestação de energia elétrica. A inexplicável demora de sua parte em atender aos pedidos de reparação e ligação da luz era uma reclamação freqüente dos munícipes. Na crônica Coisas da Vida, de 05/03/1934, um homem cobra da empresa o abastecimento de energia elétrica para sua nova residência, e por vários dias. Sem obter sucesso e esgotado, ele tem um ataque de nervos, pois não admite ter pago por um serviço que não lhe foi prestado. A crônica se encerra com o indivíduo completamente fora de si, insano. Belmonte sugere que, além de ser louca, a sociedade moderna provocava a loucura entre os cidadãos.

\footnotetext{
${ }^{442}$ Ver Paul Singer. Desenvolvimento Econômico e Evolução Urbana (análise da evolução econômica de São Paulo, Blumenau, Porto Alegre, Belo Horizonte e Recife). São Paulo: Companhia Editora nacional/Editora da Universidade de São Paulo, 1968, p. 58. As estatísticas referentes ao crescimento da população paulista no mesmo período, oferecidas por Richard Morse, são muito próximas das de Singer. Ver Richard Morse, op. cit., p. 365.

${ }^{443}$ Ver Paul Singer, op. cit., p. 49.

444 Cf. Regina Helena Alves da Silva. São Paulo. A Invenção da Metrópole. Tese de Doutorado em História Social apresentada à FFLCH/USP. São Paulo: digitado, 1997, pp. 62-64. Ver também Richard Morse, op. cit.
} 
O alto valor das passagens e contas cobradas pela empresa, assim como a avantajada taxa dos impostos municipais e estaduais e federais, é criticado no último parágrafo de Carta Aberta ao prof. Desiderius Paap:

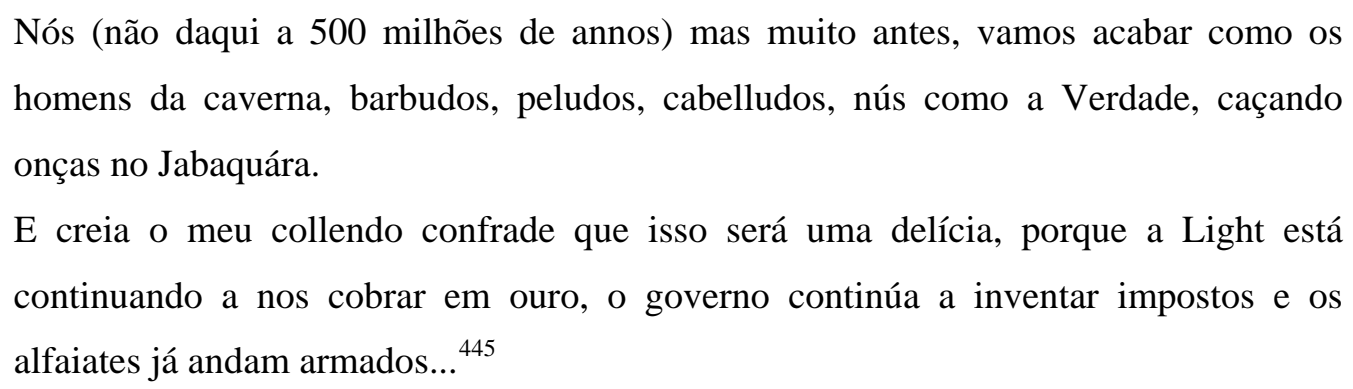

Também é denunciada a incompetência da prefeitura em prover o serviço de água encanada aos munícipes. Vemos isto na crônica Scenas Domésticas, de 26/12/1932. Um chefe de família chega a sua casa de seu trabalho diário, após um dia extremamente quente, e se vê impossibilitado de se banhar ou até mesmo de jantar, pois como sua esposa poderia cozinhar sem água?

As constantes e intermináveis reformas no centro de São Paulo, visando o alargamento de suas vias, uma vez que a região central, especialmente aquela conhecida por triângulo - confluência das ruas Quinze de Novembro, São Bento e Direita - se tornava local de passagem e de trabalho, excluindo ou dificultando, a partir de então, o flanar a passeio ou sem rumo de seus habitantes ${ }^{446}$, atrapalhavam os transeuntes, perdidos com as novas regras para a circulação. Os guardas com seus apitos e os sinais, novos atores no espaço público de uma cidade que se desenvolvia rápida e desordenadamente, não eram suficientes para organizar o trajeto de pessoas e automóveis, pois os paulistanos não conseguiam acompanhar o dinâmico crescimento da urbe. Conforme as palavras de Regina Helena Alves da Silva,

A racionalidade técnica dos traçados e sinais produzidos para orientar e melhorar a circulação destrói os antigos caminhos, desorienta os sentidos dos habitantes da cidade. ${ }^{447}$

\footnotetext{
${ }^{445}$ Belmonte, Carta Aberta ao prof. Desiderius Paap. Crônica publicada na Folha da Noite (São Paulo) em 08/02/1934, p. 2.

${ }^{446}$ Cf. Regina Helena Alves da Silva, op. Cit., pp. 119-120.

${ }^{447}$ Idem, p. 122.
} 
Os transtornos causados pela sinalização insuficiente e confusa, pelos guardas mal-treinados e impacientes, por calçadas destruídas e ruas intransitáveis, porque absolutamente esburacadas, imprimiam sua presença nas crônicas de Belmonte.

Recebendo gente de todos os lados do país e do mundo, São Paulo parecia por vezes uma imensa Babel. Mas nem todas as pessoas que chegavam à cidade conseguiam se estabelecer em alguma ocupação profissional e, consequentemente, obter renda para pagar uma pensão ou um aluguel. Também não eram todos que logravam algum espaço nos milhares de cortiços espalhados pelos bairros pobres (Brás, Mooca, Bexiga, Barra Funda e Bom Retiro), morada dos trabalhadores industriais e domésticos. Por esses motivos, os sem-teto viviam e perambulavam nas proximidades das igrejas, em praças e ruas, implorando algumas moedas aos transeuntes. E o descaso do poder público pela situação desses indigentes figurava em algumas das crônicas de Belmonte; é o caso de $A$ taxa de duzentão, de 29/12/32, e de Deve Haver, de 05/09/33, entre outras.

Os mendigos e desocupados, de um modo geral, intranqüilizavam os moradores de São Paulo, pois estes acreditavam que os outros favoreciam a desordem social, engrossando as fileiras dos golpistas e ladrões. Esta visão preconceituosa que os paulistanos das camadas médias e da classe dominante tinham dos sem-emprego e sem-residência, assim como o sentimento de insegurança perante a ascensão do número de furtos e invasões a domicílios na capital paulista, estão estampados na crônica As duas guardas, publicada na Folha da Noite em agosto de 1934.

Portanto, por mais que o crescimento dinâmico de São Paulo e o "ar” de modernidade da cidade despertassem orgulho em parte de seus moradores, o sentimento de desconforto, causado pelas mudanças abruptas, se mostrava ainda mais presente.

Nas crônicas do artista, ainda que algumas poucas elogiem certos aspectos do desenvolvimento de São Paulo como, por exemplo, a beleza e a imponência dos viadutos ${ }^{448}$, a maior parte delas mostra a modernização e o crescimento da urbe com desalento, pois estas mudanças são impostas e executadas pelos administradores municipais de forma completamente desvinculada das necessidades e da realidade de grandes parcelas dos paulistanos, o que terminava por desencadear todos os problemas sobre os quais discorremos acima.

Às questões da urbanização somavam-se os confrontos bélicos. Nas décadas de 20 e 30, as terras de São Paulo tremeram sob o impacto de conflitos armados. Lembremos que, em um período de tempo um pouco inferior a dez anos, a capital do estado foi invadida pelo exército duas vezes: a primeira em 1924 e a segunda, dolorosa derrota para o orgulho dos paulistas e paulistanos, em 1932.

\footnotetext{
${ }^{448}$ Como em O Viaduto e a ladeira. Crônica publicada na Folha da Noite (São Paulo) em 18/02/1935, p. 2.
} 
Ambas as invasões constituíram-se em um abalo considerável para aqueles habitantes que se acreditavam prosseguidores dos destemidos bandeirantes, e pertencentes a uma região que personificava a segura liderança que conduziria o Brasil para o desenvolvimento e o progresso.

Entre os dias 5 e 28 de julho de 1924, a cidade de São Paulo foi constantemente bombardeada, e as vias do centro (especialmente a Praça da Sé e os arredores) transformaram-se em campo de guerra, onde soldados legalistas e rebeldes fizeram trincheiras com os paralelepípedos retirados das ruas e arame farpado. Atirando uns contra os outros, as mortes ocorriam na vista de todos os cidadãos, que também corriam risco de serem alvejados.

O trânsito permaneceu impedido por causa das trincheiras e das batalhas nas Ruas São Bento, Quintino Bocaiúva e Direita, além de outras. No dia 6, os telefones já estavam desligados e não havia mais luz e energia elétrica na cidade.

No dia 11, os bairros proletários do Belenzinho, Brás e Mooca começaram a sofrer bombardeios, seguidos de intensa fuzilaria. Travavam-se combates na rua, num tiroteio contínuo que apavorava toda a gente. Seguidamente estouravam obuses e granadas de vários calibres, que varavam casas pobres, muitas vezes várias moradias, com isso matando, ferindo, destruindo, apavorando. Os moradores dessas zonas atingidas, acometidos de pânico, juntavam o que podiam e dali se retiravam sem rumo certo. Entretanto, as ruas esburacadas pelos obuses e pelas trincheiras dificultavam a movimentação dos habitantes em fuga, que ficavam, inclusive, suscetíveis à mira dos soldados do governo federal, crentes de que os paulistanos apoiavam os rebeldes; logo, os militares legalistas atiravam indiscriminadamente. Conforme as palavras de Helio Silva,

Era um desfilar de gente espavorida, arcada ao peso da bagagem, desesperada pela desgraça que a atingia. Famílias inteiras se deslocavam nessa via dolorosa, lembrando os refugiados europeus, pelas estradas, por ocasião da ocupação alemã na Primeira Guerra Mundial. $^{449}$

Havia na cidade muitos desabrigados, feridos que necessitavam de cuidados médicos, e cadáveres de pessoas e animais a serem recolhidos. Nesta prolongada luta, morreram 723 civis e feriram-se 2.300 pessoas, segundo o registro que restou de um único hospital, a Santa Casa. Uma

\footnotetext{
${ }^{449}$ Cf. Helio Silva; Maria Cecília Ribas CARNEIRO. História da República Brasileira. São Paulo: Editora Três, 1975, p. 125.
} 
média de 30 cadáveres e 100 feridos por dia ${ }^{450}$. E é possível afirmar que o bombardeio foi generalizado na área urbana. Brás, Mooca, Ipiranga, Vila Mariana, Cambuci, Liberdade, Ipiranga, Higienópolis, Vila Buarque e até a Rua Augusta tiveram casas, edifícios e lojas atingidos pelas balas $^{451}$.

Portanto, no mês de julho de 1924, parte considerável dos paulistanos teve um contato direto com o cotidiano bélico moderno, com seus arrasadores armamentos e a sua imensa capacidade de destruição. Esse contato deve ter sido, indubitavelmente, traumático. E Belmonte provavelmente foi um dos que muito se impressionou com ele, pois as referências a atividades militares passaram a ser constantes em seus escritos, sobretudo na década seguinte, quando houve a Revolução de 1932 e a possibilidade, cada vez mais evidente, da eclosão de uma nova grande guerra internacional.

Anos mais tarde, na Revolução de 1932, a cidade de São Paulo sofreu poucos danos físicos e materiais durante a guerra civil, assim como não houve muitas mortes decorrentes dela no interior de seus limites. Ainda assim, esta nova guerra veio a corroborar com a impressão de que o capital, aliado ao avanço tecnológico, tornou-se determinante para a vitória de uma causa, qualquer que fosse ela. E os paulistas que se engajaram no movimento não tinham dúvidas de que lutavam pelos mais elevados ideais: “liberdade” e “democracia”.

A luta pelo constitucionalismo contou com a participação de todas as classes sociais de São Paulo, sobretudo das camadas médias e das elites ${ }^{452}$, sob os brados de “...em frente, bandeirantes!” e “...São Paulo unido pelo Brasil!”. Mas todo o vigor e entusiasmo dos paulistas contra o Governo Provisório de Getúlio Vargas não bastaram; eles foram submetidos, entre outras coisas, pela carência de material bélico e falta de planejamento, falhas inconcebíveis nas novas guerras do século XX:

O que também ficou patente, entretanto, foi que, na idade moderna, convicção e esperança apenas podem sustentar-se pelo planejamento bem informado de ordem altamente complexa. O entusiasmo, destituído de agudo discernimento da realidade, contribui para a sua própria derrota. A Paixão pública é hoje muito menos indissoluvelmente ligada á ação eficiente. O esforço de guerra dos paulistas foi prejudicado pela prematuridade e por erros fundamentais de cálculo (...). Depois, quando se tornou evidente que não se tinham tomado as necessárias medidas que garantissem a aliança ou a neutralidade dos Estados vizinhos, os comandantes e a

\footnotetext{
${ }^{450}$ Cf. Ilka Stern Cohen. Bombas sobre São Paulo: a Revolução de 1924. São Paulo: UNESP, 2007, pp. 104-128 passim. ${ }^{451}$ Idem, Ibidem.

${ }^{452}$ As elites paulistas (grandes industriais, cafeicultores, comerciantes) e as camadas médias aderiram entusiasticamente à Revolução de 1932. Mas parte considerável do operariado ficou indiferente a ela. Ver Vavy Pacheco Borges. Memória Paulista. São Paulo: EDUSP, 1997, p. 19 e 47. Ver Maria Helena Capelato, 1981, p. 63.
} 
estratégia militares não estavam preparados para um combate continuado em muitas frentes. Além do mais, não tinha havido tempo suficiente para transformar o parque industrial. As tropas recebiam chocolate, conservas, vinho e dentifrícios em grande quantidade mas, a despeito do valioso esforço industrial, equipamento bélico insuficiente. $^{453}$

A grande "luta cívica" foi tragicamente terminada. O enorme empenho industrial paulista improvisado para o esforço de guerra, e que mobilizou ao máximo técnicos, engenheiros e operários $^{454}$ - não bastou à produção suficiente de armas. As tropas que lutavam a favor do Governo Federal estavam mais bem supridas de equipamentos bélicos, e a inferioridade no número de homens do exército rebelde também contribuiu para o fracasso do movimento. Durante um período de quase três meses, cerca de 40 mil brasileiros das forças constitucionalistas combateram aproximadamente 120 mil brasileiros de outros estados da União ${ }^{455}$.

Portanto, os paulistanos contemporâneos às crônicas de Belmonte tiveram em sua história recente um contato um tanto brutal com a tecnologia. A Revolução de 1924 e a frustrante derrota de 1932 evidenciaram aos paulistas que pouco importava a "grandeza” de seus ideais pró-democracia e pró-constituição; o planejamento, a produção e o investimento de capitais passaram a ser determinantes para o triunfo de um conflito militar.

Apenas após essas longas considerações podemos compreender algo mais da visão negativa de Belmonte em relação à tecnologia e à modernidade, a ponto de relacioná-las constantemente com a ação bélica. Segundo Belmonte, “São Paulo”, que sempre demonstrou valorizar o desenvolvimento e o progresso da nação, terminou submetido por um grupo de políticos aventureiros e autoritários, mas que, em contrapartida, tinha o Governo Federal em suas mãos e, consequentemente, capital suficiente para adquirir uma tecnologia de inegável superioridade.

Por isso, para o artista, uma das características principais da contemporaneidade consiste na inversão absoluta; nela, o materialismo, o “ter” e o "submeter” são muito mais incisivos e determinantes do que todos os belos (mas transformados em vago palavreado em um mundo dominado pela força) conceitos modernos, tais como "justiça”, "liberdade”, “individualidade”, “democracia” e “paz”. E essa realidade é relatada com profunda amargura pelo cronista:

\footnotetext{
${ }^{453}$ Richard Morse, op. cit., p. 327.

${ }^{454}$ Ibidem, p. 126.

${ }^{455}$ Ver Jeziel de Paula, op. cit., p. 172.
} 
O que acontece é que essas illustres entidades [as indústrias de armamentos] tratam de negociar suas armas com quem lhes offerece melhores garantias. É um direito que lhes assiste, porque cada um se defende como pode. Tanto que, quando São Paulo desencadeou a Revolução de 1932, teve que brigar com pica-paus e cabos de vassoura, porque as fábricas de armamentos viram logo que era mais garantido negociar com a dictadura. E foi esse, em verdade, o melhor negocio que as usinas bellicas norteamericanas realizaram depois da guerra européa. Está claro que não sou eu quem o affirma. É um jornal yankee, 'The New Republic’ de Nova York, quem escreve essas linhas:

'Para finalizar, assignalemos que depois de 1919, os melhores negócios registrados pelos nossos fabricantes de armas foram os devidos á sangrenta revolução paulista de 1932. Proclamando o embargo de armas para os revolucionários de São Paulo, o secretário de Estado, Stimson, encorajou abertamente a venda de material de guerra americano ao governo do Rio de Janeiro. E, com effeito, este comprou aos Estados Unidos 111 aviões (representando um valor de 2.282.000 dollares) assim como peças de artilharia, num valor de 236.232 dollares. ${ }^{456}$

Na modernidade, a respeitabilidade das regiões e países passou a gravitar, cada vez mais, em torno daqueles que têm poder e riqueza suficientes para obter ou fabricar armas de grande capacidade tecnológica. Indubitavelmente, não há mais como se levar em consideração a capacidade ou a destreza individual, de modo que este aspecto da história humana parece pertencer ao passado: um exército de valentes homens armados com espingardas, ou até mesmo com metralhadoras, nada podia fazer contra um tanque de guerra e contra aviões que despejavam obuses; seria como tentar ganhar a Revolução de 1932 por meio do som das matracas. Nesse sentido, segundo a visão de Belmonte, o espírito de ousadia que caracterizou a épica aventura dos bandeirantes dos séculos XVII-XVIII, com seus aguerridos e heróicos “Raposos Tavares” e “Borba Gatos”, não mais poderia se repetir no presente, impressão esta reafirmada com a derrota da Revolução Paulista.

A valorização da individualidade, que permitia a ação heróica das pessoas, assim como a autonomia regional e a descentralização política - relacionadas, por sua vez, com a liberdade e a democracia - eram aspectos que vinham sendo conquistados pelos paulistas para o restante do país durante toda a sua história. Tratavam-se de características inerentes a "São Paulo”. Eis, portanto, os passos do progresso: o desenvolvimento do país sob a dianteira de "São Paulo”. O oposto deste modelo, que, na visão de Belmonte, configurava-se em uma inversão, consistia nos seres humanos

${ }^{456}$ Belmonte, “Os ‘profiteurs’”. Crônica publicada na Folha da Noite (São Paulo) em 05/11/1934, p. 2. 
destituídos da condição de donos de seus destinos, submetidos pela tecnologia moderna e despersonalizados; coisificados por Estados autoritários que, não obstante, controlavam-na.

Essa interpretação épica do distante passado paulista que se afigura em algumas das crônicas de Belmonte e nas páginas do seu livro No Tempo dos Bandeirantes ${ }^{457}$, publicado em 1939, não foi uma criação sua. Esta leitura da história de São Paulo já era veiculada desde, pelo menos, a década anterior por historiadores regionais de prestígio, como Afonso de E. Taunay, Alcântara Machado, Alfredo Ellis Jr., e, também, pelos literatos Paulo Prado e Cassiano Ricardo ${ }^{458}$. Belmonte transmitiu e sublinhou essa idéia do heroísmo bandeirante aos seus leitores por meio de suas linhas, sobretudo durante e após a Revolução de 1932, mas ela já era bem conhecida entre os intelectuais paulistas. Todavia, o artista inovou ao colocar como contraponto do valente bandeirante mameluco do século XVII, que empreendera uma verdadeira aventura épica para consolidar o território brasileiro, o soldado das guerras modernas. Para este, impedido de sair de seu esconderijo e mostrar sua personalidade construindo sua história pessoal, como fizeram os homens de Piratininga no passado, restou-lhe apenas apertar-se com seus companheiros de infortúnio no fundo da trincheira, ou correr quando pressentisse a aproximação de um ataque aéreo.

Assim, nesses dois anos e meio de crônicas publicadas na Folha da Noite, percebemos um Belmonte compenetrado em tecer algumas relações por meio de suas linhas (e entrelinhas), relações estas cindidas em dois grupos: um mais positivo, favorável ao individualismo, à democracia e à liberdade, e do qual o maior representante era "São Paulo". O outro, inimigo declarado dos preceitos liberais, cujo grande representante era o Nazi-fascismo e seus similares no Brasil (o governo revolucionário e o Integralismo), era anti-nacional e absolutamente exógeno à cultura do país, uma vez que, até então, o Brasil fora conduzido pelos paulistas e por seus valores liberais - esses sim genuinamente nacionais, segundo o artista.

Temos, portanto, um material paradoxal. Por um lado, as crônicas mostram um perfil progressista quando criticam o Nazi-fascismo. Ao sugerirem que esse regime político buscava estandardizar a conduta dos seres humanos, eliminando sua personalidade e transformando-os em simples instrumentos para a conquista e a guerra, elas surgem como libelos literários contra ele. Quando apreendemos as críticas direcionadas ao Nazi-fascismo, nos surpreendemos, portanto, com a clarividência do artista, assim como quando elas se desdobram ao governo revolucionário e ao Integralismo. Entretanto, se tomadas em conjunto, as crônicas compreendem dois sentidos. Um é,

\footnotetext{
${ }^{457}$ Cf. principalmente o capítulo “A Vila de São Paulo”, da pp.11-18.

${ }^{458}$ Cf. Ferreira, Antonio Celso. A Epopéia Bandeirante: letrados, instituições, invenção histórica (1870-1940). São Paulo: Editora Unesp, 2002, pp.276-335. Ver também Danilo José Zioni Ferretti, op. Cit., pp. 288-343.
} 
indubitavelmente, o do pensamento progressista, antifascista. Mas o outro é marcadamente diverso dele, pois revela uma valorização da ideologia da paulistanidade e do predomínio da elite paulista sobre todo o Brasil. Belmonte foi um homem de seu tempo e veiculou pelos escritos impressos na Folha da Noite, portanto, idéias que exaltavam o ser paulista. Entretanto, cabe salientar que ele conseguiu transformar aquele viés crítico - anti-autoritário, antifascista e anti-bélico - também em “seu tempo”, impressionando-nos com a sua clarividência.

Quando da sua crítica ao desenvolvimento científico e técnico, o artista buscou dialogar com produções culturais de grande destaque e alcance na época, como o romance de Erich Maria Remarque e o filme de Lewis Milstone. Em comum, essas obras apresentam indivíduos mutilados psiquicamente, despersonalizados. Homens que agiam impulsionados, sobretudo, pelo seu instinto de sobrevivência, e onde a razão permanecia em repouso. Nesse sentido, o mundo moderno surgia como um retrocesso.

Ainda que Belmonte reconhecesse que a modernidade pudesse ser ambivalente, ter um sentido positivo e outro negativo, ele acreditava que o segundo era mais expressivamente empregado, pois, aos restritos grupos que possuíam o controle político e econômico dos países, as guerras e as conquistas territoriais eram-lhes vantajosas não só para manter seu poderio, como, inclusive, para expandi-lo.

As sociedades das quais Belmonte ria estavam, segundo ele, completamente tomadas pelo seu avesso: "regeneradores” da política e da democracia que se revelaram ditadores; a falência do regime democrático e a ascensão dos autoritários governos “de força”; o desenvolvimento científico e técnico, que se revelou um eficiente carrasco da humanidade; o poder estatal e as grandes fortunas, que tornaram a vida da maior parte dos homens descartável; a civilização ocidental, que não é capaz de extirpar o desenvolvimento da barbárie; e, por fim, o homem, a única criatura pensante deste mundo, que cultiva, sem titubear, o irracionalismo e a auto-destruição.

Diante das desilusões e enganos engendrados, percebe-se um sem-número de esperanças frustradas e a certeza incontestável da vitória do avesso. O humorista ataca o avesso, denunciando-o, principalmente, através da ironia. E, por um instante, seja pela percepção da própria sagacidade ou por meio do desvelamento e da desqualificação do inimigo, o cômico o faz sentir muito mais poderoso do que lhe impõe sua frágil condição humana, a ele e aos seus leitores. Ri-se do poder instituído através do poder da retórica. Momentaneamente, com o rir, o fraco sente-se forte, e goza desta rápida inversão da qual ele é o protagonista. O avesso impresso nas linhas e entrelinhas das 
crônicas é usado para se apontar e se rir do próprio avesso propagado pelas ações dos poderosos, das contradições humanas. Soberano na ironia, Belmonte flertou o avesso com admirável maestria. 


\section{Algumas Conclusões e Perspectivas}

Através da crítica sistemática ao moderno, ao novo, Belmonte procurou desprestigiar tanto o governo Vargas como o Nazi-fascismo, uma vez que ambos se apresentavam como uma novidade. A oposição ao governo brasileiro revolucionário, largamente presente nas crônicas do artista, pode ser compreendida como a incapacidade das classes dominantes e médias paulistas em aceitar a participação mais discreta de São Paulo na economia e na política do país, após a Revolução de 1930 e o fracasso do movimento paulista de 1932. O fato de nossas pesquisas sugerirem que o principal público leitor da Folha da Noite e das crônicas de Belmonte pertencia às classes intermediárias da população, e de que o jornal disseminava um ideário liberal, pode ajudar-nos a compreender porque o governo de Vargas era criticado nos editoriais da Folha e, sobretudo com uma zombaria ferina, nas crônicas. A exaltação da paulistanidade era uma tônica comum tanto aos editoriais da Folha da Noite como dos escritos de Belmonte.

O cronista almejou apresentar o governo revolucionário como uma falsa novidade que continha características de continuidade ou mesmo de retrocessão, de sorte que ele figura em suas linhas possuindo as mesmas falhas do governo anterior ou ainda mais antigo que ele, configurandose, nesse sentido, em uma nova espécie de “velharia” - monarquia ou regime aristocrático e feudal.

Sugerimos, também, que a amargura e a frustração que emergem das crônicas de Belmonte com relação ao governo revolucionário não dizem respeito apenas aos ocasos, para os paulistas, da Revolução de 1930 e a de 1932. Estão relacionadas, também, com o profundo desapontamento das classes médias de São Paulo com os parlamentares por elas eleitos para comporem a Assembléia Nacional Constituinte; progressivamente, a concordância deles com Getúlio Vargas e os políticos revolucionários foi se estreitando. Ao mesmo tempo em que percebemos em algumas das crônicas críticas à indulgência dos parlamentares, nos editoriais da Folha da Noite elas são bem mais moderadas.

Acreditamos que a repulsa de Belmonte ao Nazi-fascismo, expressa em suas crônicas, tratouse de um posicionamento precoce e inédito, tendo em vista que pelo menos até fins dos anos 30, a imprensa tendia a ser condescendente com relação à imagem dos regimes de Hitler e Mussolini. Nesse aspecto, as linhas de Belmonte se diferenciavam dos editoriais da Folha da Noite, uma vez que eles praticamente silenciaram frente ao Nazi-fascismo (assim como perante o Integralismo). De 1932 a 1935, não encontramos sequer quinze editoriais que se posicionassem frente aos fascismos. É muito pouco se pensarmos que todos os dias se publicavam editoriais. 
Em suas críticas aos regimes de extrema-direita, o cronista buscou, direta ou indiretamente, relacionar o governo de Getúlio Vargas e o Integralismo com eles, destacando o nacionalismo exacerbado deles, o apelo à coletividade e a desvalorização da individualidade, e o desprezo à democracia, ainda que, no caso dos fascistas, esta última característica fosse mais acentuada. Por meio de suas linhas, Belmonte intentou alertar seu público leitor das concepções do governo revolucionário e dos integralistas, uma vez que parte das classes médias apoiou a AIB.

O desenvolvimento científico e a modernidade, em especial a modernidade técnica, configuram-se, para Belmonte, como promessas frustradas de progresso e bem-estar para a humanidade. Eles se revelaram uma farsa, engendrando a dominação e a violência ilimitadas. Constituíram-se em uma enganação, assim como uma outra novidade, o governo revolucionário de Getúlio Vargas, que ascendeu ao poder em 1930 com a promessa de regenerar a República e edificar a democracia. Entretanto, alcançado o predomínio da máquina administrativa, os getulistas se mostraram muito mais afeitos aos regimes ditatoriais.

O desconforto belmonteano perante a modernidade estava intrinsecamente relacionado com a compreensão de que a ascensão dos governos fascistas só foi possível por causa do acelerado desenvolvimento científico e tecnológico, que possibilitou a existência de uma eficiente e poderosa estrutura de propaganda para seduzir as mentes a apoiarem o regime, estrutura esta jamais vista antes. Ainda segundo a concepção do artista, o impressionante avanço da tecnologia bélica das últimas décadas conduziria a humanidade a uma nova grande guerra e ela contaria, provavelmente, com a participação dos Nazi-fascistas, uma vez que eles sempre se mostraram marcadamente nacionalistas e imperialistas. Nesse sentido, tanto o desenvolvimento técnico e científico dos últimos dois séculos como os regimes fascistas possuem um aspecto de confluência: ambos projetam uma dominação inédita sobre os seres humanos. Se no início eles se apresentavam como uma panacéia, esta se revelou uma farsa violenta e não-controlável.

Percebe-se que Belmonte traçou um paralelo entre o novo, o governo de Getúlio Vargas, os fascismos e a modernidade técnica. Para todos eles, o artista elaborou uma concepção negativa e absolutamente inversa às características (supostamente) liberais e progressistas dos paulistas.

Entretanto, ainda sobre a modernidade, vale destacar que Belmonte sempre lembrava, diretamente ou nas entrelinhas, das promessas originais mas frustradas da mesma, o que evidencia alguma esperança - ainda que remota - em relação aos potenciais daqueles valores em seu estado autêntico. 
O artista possuía uma liberdade opinativa no jornal, ainda que ela tivesse alguns limites. Ele pôde zombar à vontade da modernidade técnica em suas crônicas, assim como escarnecer do Nazifascismo. Todavia, quanto a este último, acreditamos que, devido à origem social do público leitor e o apoio de parte dele aos regimes políticos de extrema-direita, Belmonte não teve a liberdade de publicar um número tão grande de crônicas antifascistas quanto aquelas destinadas à crítica à modernidade, ainda que elas fossem inteiramente demolidoras.

Suas críticas contra a coisificação humana perpetrada por governos e regimes autoritários, com destaque para o Nazismo, e pela modernidade técnica são impressionantes; por vezes, relutamos em acreditar que essas crônicas foram escritas na primeira metade da década de trinta, e não em fins da Segunda Guerra Mundial. Os ataques de Belmonte à coisificação humana, à valorização inquestionável da obediência e da eficiência e à destruição de um espaço público (político) democrático, ações estas perpetradas pelo Nazi-fascismo, nos fazem lembrar as reflexões de Hannah Arendt ${ }^{459}$, publicadas mais de uma década depois das crônicas do artista paulistano na Folha da Noite.

Mas, por outro lado, Belmonte jamais criticou a coisificação humana inerente à própria produção capitalista. E nunca apontou a ideologia da paulistanidade como um conjunto de idéias voltado para a justificação da dominação da elite paulista sobre todo o Brasil, sobretudo sobre os trabalhadores brasileiros - paulistas e de outros estados.

Apesar desses limites, importantes conquistas críticas foram atingidas, atestando a vitória da criação literária e artística em relação a amarras ideológicas e evidenciando possibilidades de autonomia da produção intelectual na imprensa comercial diante dos valores políticos dominantes, além de refinadas nuances no campo da argumentação liberal sob a forma de literatura e humor.

Nesse sentido, Belmonte figura, nas crônicas abordadas, como uma voz de literatura e imprensa capaz de enfrentar argumentos brasileiros e internacionais que tiveram poderosa vigência na cena política da época.

${ }^{459}$ Páginas 100/101. 


\section{$\underline{\text { Acervos e Bibliotecas }}$}

\section{Acervos:}

Folha da Noite (1921-10/1930 e 1931-1960) - Hemeroteca do Arquivo do Estado de São Paulo $\mathrm{AE} / \mathrm{SP}$.

Folha da Manhã (1921-10/1930 e 1931-1960) - Hemeroteca do Arquivo do Estado de São Paulo $\mathrm{AE} / \mathrm{SP}$.

Folha da Noite (1921-10/1930 e 1931-1960) - Hemeroteca da Folha de São Paulo - Acervo pertencente à Empresa do Grupo Folha da Manhã S. A.

Folha da Manhã (1921-10/1930 e 1931-1960) - Hemeroteca da Folha de São Paulo - Acervo pertencente à Empresa do Grupo Folha da Manhã S. A.

\section{Bibliotecas:}

Biblioteca de Filosofia, Letras e Ciências Humanas - FFLCH/USP

Biblioteca do Instituto de Estudos Brasileiros/USP

Biblioteca da Escola de Comunicações e Artes/USP

Biblioteca do Arquivo do Estado de São Paulo

Biblioteca do Instituto de Artes/UNESP

\section{Páginas da Internet (sites):}

Página do jornal Folha de São Paulo:

http://almanaque.folha.uol.com.br/belmonte.htm

Acesso em: 02. mar. 2009.

Página da União Brasileira de Escritores:

http://www.ube.org.br

Acesso em: 22. nov. 2008.

Vídeo:

BELMONTE

Gênero: documentário

Dir. Ivo Branco

Ano: 1981.

Duração: 11 minutos.

Cor: P \& B. 


\section{Fontes Principais}

Crônica O Caso do Sião. Publicada na Folha da Noite em 11/10/1932 na p. 2.

Crônica Do Terror. Publicada na Folha da Noite em 20/10/1932 na p. 2.

Crônica A Bruxaria do Brocken. Publicada na Folha da Noite em 21/10/1932 na p. 2.

Crônica Da Arte. Publicada na Folha da Noite em 24/10/1932 na p. 2.

Crônica $\boldsymbol{O}$ “Snr. Redactor”. Publicada na Folha da Noite em 05/11/1932 na p. 2.

Crônica $\boldsymbol{O}$ Jogo. Publicada na Folha da Noite em 07/11/1932 na p. 2.

Crônica Um regime novo. Publicada na Folha da Noite em 08/11/1932 na p. 2.

Crônica Uma nova guerra? Publicada na Folha da Noite em 11/11/1932 na p. 2.

Crônica Livros para crianças. Publicada na Folha da Noite em 12/11/1932 na p. 2.

Crônica $\boldsymbol{O}$ drama do mundo. Publicada na Folha da Noite em 14/11/1932 na p. 2.

Crônica $\boldsymbol{O}$ “Crack” Publicada na Folha da Noite em 16/11/1932 na p. 2.

Crônica Os Salvadores. Publicada na Folha da Noite em 17/11/1932 na p. 2.

Crônica “Eu táva na roda no samba...” Publicada na Folha da Noite em 21/11/1932 na p. 2.

Crônica O chapéu na cabeça. Publicada na Folha da Noite em 23/11/1932 na p. 2.

Crônica A cabeça com chapéo. Publicada na Folha da Noite em 24/11/1932 na p. 2.

Crônica Louco por que? Publicada na Folha da Noite em 25/11/1932 na p. 2.

Crônica O nosso hymno. Publicada na Folha da Noite em 01/12/1932 na p. 2.

Crônica Não há tempo a perder. Publicada na Folha da Noite em 05/12/1932 na p. 2.

Crônica Estilha. Publicada na Folha da Noite em 06/12/1932 na p. 2.

Crônica Novos rumos... Publicada na Folha da Noite em 09/12/1932 na p. 2.

Crônica Pêsames. Publicada na Folha da Noite em 10/12/1932 na p. 2.

Crônica Amor... Publicada na Folha da Noite em 13/12/1932 na p. 2.

Crônica $\boldsymbol{O}$ Crise. Publicada na Folha da Noite em 14/12/1932 na p. 2.

Crônica Viagem Necessária. Publicada na Folha da Noite em 17/12/1932 na p. 2.

Crônica A Epidemia. Publicada na Folha da Noite em 20/12/1932 na p. 2.

Crônica $\boldsymbol{O}$ Centro. Publicada na Folha da Noite em 24/12/1932 na p. 2.

Crônica Cenas domésticas. Publicada na Folha da Noite em 26/12/1932 na p. 2.

Crônica “Ne sutor, ultra crepidam...”. Publicada na Folha da Noite em 27/12/1932 na p. 2.

Crônica A taxa de duzentão. Publicada na Folha da Noite em 29/12/1932 na p. 2.

Crônica O Povo. Publicada na Folha da Noite em 30/12/1932 na p. 2.

Crônica O Palácio. Publicada na Folha da Noite em 03/01/1933 na p. 2.

Crônica O Nú. Publicada na Folha da Noite em 04/01/1933 na p. 2.

Crônica Uma Idéa. Publicada na Folha da Noite em 06/01/1933 na p. 2. 
Crônica Paschoal, babão e etc. Publicada na Folha da Noite em 07/01/1933 na p. 2.

Crônica Um Monstro. Publicada na Folha da Noite em 09/01/1933 na p. 2.

Crônica Sciencia. Publicada na Folha da Noite em 10/01/1933 na p. 2.

Crônica Medicina. Publicada na Folha da Noite em 13/01/1933 na p. 2.

Crônica As Phillipinas. Publicada na Folha da Noite em 18/01/1933 na p. 2.

Crônica A Irlanda. Publicada na Folha da Noite em 20/01/1933 na p. 2.

Crônica Producção. Publicada na Folha da Noite em 23/01/1933 na p. 2.

Crônica Do Cinema. Publicada na Folha da Noite em 24/01/1933 na p. 2.

Crônica Os Civilizados. Publicada na Folha da Noite em 25/01/1933 na p. 2.

Crônica O raio que o parta. Publicada na Folha da Noite em 28/01/1933 na p. 2.

Crônica Um Homem Corajoso. Publicada na Folha da Noite em 31/01/1933 na p. 2.

Crônica A vez das mulheres. Publicada na Folha da Noite em 01/02/1933 na p. 2.

Crônica Hitler Chanceler! Publicada na Folha da Noite em 02/02/1933 na p. 2.

Crônica Amor em praça publica. Publicada na Folha da Noite em 04/02/1933 na p. 2.

Crônica Acção. Publicada na Folha da Noite em 08/02/1933 na p. 2.

Crônica Retrato do Brasil. Publicada na Folha da Noite em 10/02/1933 na p. 2.

Crônica Escolas sem fachada... Publicada na Folha da Noite em 14/02/1933 na p. 2.

Crônica A chegada do heróe. Publicada na Folha da Noite em 16/02/1933 na p. 2.

Crônica Profissionalismo Político. Publicada na Folha da Noite em 18/02/1933 na p. 2.

Crônica Intelligencia. Publicada na Folha da Noite em 20/02/1933 na p. 2.

Crônica Religião e Progresso. Publicada na Folha da Noite em 25/02/1933 na p. 2.

Crônica Superstições. Publicada na Folha da Noite em 04/03/1933 na p. 2.

Crônica Todo Frajola. Publicada na Folha da Noite em 06/03/1933 na p. 2.

Crônica Saudades... Publicada na Folha da Noite em 08/03/1933 na p. 2.

Crônica Riqueza! Publicada na Folha da Noite em 10/03/1933 na p. 2; Idéas de João Ninguém 1935.

Crônica A Força da Opinião e a Opinião da Força. Publicada na Folha da Noite em 11/03/1933 na p. 2.

Crônica A guerra que vem ahí... Publicada na Folha da Noite em 14/03/1933 na p. 2.

Crônica “Apparece e desapparece!” Publicada na Folha da Noite em 16/03/1933 na p. 2.

Crônica Portugal Também. Publicada na Folha da Noite em 17/03/1933 na p. 2.

Crônica Os Presos. Publicada na Folha da Noite em 21/03/1933 na p. 2; Idéas de João Ninguém 1935.

Crônica A Nova Bandeira. Publicada na Folha da Noite em 24/03/1933 na p. 2.

Crônica As “ratas” do Instituto. Publicada na Folha da Noite em 25/03/1933 na p. 2.

Crônica Os gatos do Instituto. Publicada na Folha da Noite em 28/03/1933 na p. 2. 
Crônica Os Canhões do Papa. Publicada na Folha da Noite com o nome “PUM!” em 31/03/1933 na p. 2; Idéas de João Ninguém - 1935.

Crônica Uma Revolução muito Séria. Publicada na Folha da Noite em 01/04/1933 na página 2. E no livro Idéas de João Ninguém - 1935.

Crônica 1 de abril. Publicada na Folha da Noite em 04/04/1933 na p. 2.

Crônica Na Corda Bamba. Publicada na Folha da Noite em 06/04/1933 na p. 2.

Crônica Os Macacos. Publicada na Folha da Noite em 08/04/1933 na p. 2.

Crônica $\boldsymbol{O}$ “auri-verde pendão”. Publicada na Folha da Noite em 10/04/1933 na p. 2.

Crônica O Critério Lídimo. Publicada na Folha da Noite em 12/04/1933 na p. 2.

Crônica Um edital milagroso. Publicada na Folha da Noite em 15/04/1933 na p. 2.

Crônica Guerra aos solteirões. Publicada na Folha da Noite em 17/04/1933 na p. 2.

Crônica Um Caso... Publicada na Folha da Noite em 20/04/1933 na p. 2.

Crônica Os Candidatos. Publicada na Folha da Noite em 22/04/1933 na p. 2.

Crônica Babel. Publicada na Folha da Noite em 24/04/1933 na p. 2.

Crônica Outra bandeira. Publicada na Folha da Noite em 25/04/1933 na p. 2.

Crônica Ao Eleitorado. Publicada na Folha da Noite em 27/04/1933 na p. 2.

Crônica A minha candidatura. Publicada na Folha da Noite em 28/04/1933 na p. 2.

Crônica O meu programma. Publicada na Folha da Noite em 29/04/1933 na p. 2.

Crônica A arrancada de uma bandeira. Publicada na Folha da Noite em 02/05/1933 na p. 2.

Crônica Divagações. Publicada na Folha da Noite em 04/05/1933 na p. 2.

Crônica As angústia dos poderosos. Publicada na Folha da Noite em 05/05/1933 na p. 2.

Crônica Meu Estrillo! Publicada na Folha da Noite em 08/05/1933 na p. 2.

Crônica Exhortação! Publicada na Folha da Noite em 09/05/1933 na p. 2.

Crônica $\boldsymbol{O}$ fim está chegando... Publicada na Folha da Noite em 11/05/1933 na p. 2.

Crônica O peccado mortal. Publicada na Folha da Noite em 12/05/1933 na p. 2.

Crônica O Futuro Congresso. Publicada na Folha da Noite em 15/05/1933 na p. 2.

Crônica Representação de Classes. Publicada na Folha da Noite em 16/05/1933 na p. 2.

Crônica Opposição e Loucura. Publicada na Folha da Noite em 17/05/1933 na p. 2.

Crônica Do resultado das eleições. Publicada na Folha da Noite em 19/05/1933 na p. 2.

Crônica Turismo. Publicada na Folha da Noite em 22/05/1933 na p. 2.

Crônica A Marcha da “Idéa Nova”. Publicada na Folha da Noite em 23/05/1933 na p. 2.

Crônica Arte Moderna. Publicada na Folha da Noite em 24/05/1933 na p. 2.

Crônica Os Chiromantes da Arte. Publicada na Folha da Noite em 27/05/1933 na p. 2.

Crônica Os Allemães e a Guerra. Publicada na Folha da Noite em 29/05/1933 na p. 2. E no livro Idéas de João Ninguém - 1935.

Crônica Commercio. Publicada na Folha da Noite em 30/05/1933 na p. 2. 
Crônica Na tal idade. Publicada na Folha da Noite em 31/05/1933 na p. 2.

Crônica Multiplique-mo-nos. Publicada na Folha da Noite em 02/06/1933 na p. 2.

Crônica Uma Solução. Publicada na Folha da Noite em 03/06/1933 na p. 2.

Crônica Poesia. Publicada na Folha da Noite em 06/06/1933 na p. 2.

Crônica Falta de Assumpto. Publicada na Folha da Noite em 07/06/1933 na p. 2.

Crônica Brailowsky e o samba. Publicada na Folha da Noite em 08/06/1933 na p. 2.

Crônica Pingô e a Academia. Publicada na Folha da Noite em 09/06/1933 na p. 2.

Crônica A Vingança do Homem. Publicada na Folha da Noite em 10/06/1933 na p. 2. E no livro Idéas de João Ninguém - 1935.

Crônica A dona do gato. Publicada na Folha da Noite em 12/06/1933 na p. 2.

Crônica Pagar... Publicada na Folha da Noite em 13/06/1933 na p. 2.

Crônica “Vamos situar o Brasil”. Publicada na Folha da Noite em 16/06/1933 na p. 2.

Crônica Férias. Publicada na Folha da Noite em 20/06/1933 na p. 2.

Crônica Cartas de Algures. Publicada na Folha da Noite em 23/06/1933 na p. 2.

Crônica Salve 9 de julho! Publicada na Folha da Noite em 08/07/1933 na p. 2.

Crônica Boatos. Publicada na Folha da Noite em 10/07/1933 na p. 2.

Crônica As Crianças. Publicada na Folha da Noite em 12/07/1933 na p. 2.

Crônica Mágicas. Publicada na Folha da Noite em 14/07/1933 na p. 2.

Crônica Vida Apertada. Publicada na Folha da Noite em 21/07/1933 na p. 2.

Crônica A Intoxicação Tarifária. Publicada na Folha da Noite em 27/07/1933 na p. 2.

Crônica A Epidemia. Publicada na Folha da Noite em 29/07/1933 na p. 2.

Crônica Os Professores. Publicada na Folha da Noite em 03/08/1933 na p. 2.

Crônica A Publicidade. Publicada na Folha da Noite em 04/08/1933 na p. 2.

Crônica A Phonetica. Publicada na Folha da Noite em 05/08/1933 na p. 2.

Crônica Um Principado em apuros. Publicada na Folha da Noite em 07/08/1933 na p. 2.

Crônica “Patriota por que?...” Publicada na Folha da Noite em 08/08/1933 na p. 2.

Crônica Não me troque o nome. Publicada na Folha da Noite em 11/08/1933 na p. 2.

Crônica Censura. Publicada na Folha da Noite em 12/08/1933 na p. 2.

Crônica Coisas da Censura. Publicada na Folha da Noite em 17/08/1933 na p. 2.

Crônica Governar. Publicada na Folha da Noite em 18/08/1933 na p. 2.

Crônica O Centésimo Jejum de Gandhi. Publicada na Folha da Noite em 19/08/1933 na p. 2.

Crônica O rabo de tatu. Publicada na Folha da Noite em 21/08/1933 na p. 2.

Crônica “Juó Bananére”. Publicada na Folha da Noite em 23/08/1933 na p. 2.

Crônica As Receitas Espíritas. Publicada na Folha da Noite em 25/08/1933 na p. 2.

Crônica As novas barbas do Irineu. Publicada na Folha da Noite em 26/08/1933 na p. 2. 
Crônica Invenções. Publicada na Folha da Noite em 29/08/1933 na p. 2.

Crônica O divorcio. Publicada na Folha da Noite em 30/08/1933 na p. 2.

Crônica Aryanos e Semitas. Publicada na Folha da Noite em 31/08/1933 na p. 2.

Crônica O jogo e a moral pública. Publicada na Folha da Noite em 01/09/1933 na p. 2.

Crônica A mendicância e o jogo do bicho. Publicada na Folha da Noite em 02/09/1933 na p. 2.

Crônica Deve Haver. Publicada na Folha da Noite em 05/09/1933 na p. 2.

Crônica A História se Repete... Publicada na Folha da Noite em 06/09/1933 na p. 2.

Crônica A Indústria das Cobras. Publicada na Folha da Noite em 09/09/1933 na p. 2.

Crônica Cousas Paulistanas. Publicada na Folha da Noite em 13/09/1933 na p. 2.

Crônica “Vanitas Vanitatis”. Publicada na Folha da Noite em 15/09/1933 na p. 2.

Crônica A Mulher e os Filhos. Publicada na Folha da Noite em 19/09/1933 na p. 2.

Crônica Os Hospitaes e a Música. Publicada na Folha da Noite em 20/09/1933 - na p. 2. E no livro Idéas de João Ninguém - 1935.

Crônica A dentadura avacalhada. Publicada na Folha da Noite em 21/09/1933 - na p. 2.

Crônica O Milagre. Publicada na Folha da Noite em 22/09/1933 - na p. 2.

Crônica Um pouco de arte. Publicada na Folha da Noite em 23/09/1933 - na p. 2.

Crônica O Amor e a Política. Publicada na Folha da Noite em 25/09/1933 na p. 2.

Crônica Um que virou... Publicada na Folha da Noite em 26/09/1933 na p. 2.

Crônica Escolas! Escolas! Publicada na Folha da Noite em 28/09/1933 - na p. 2.

Crônica As Bonecas. Publicada na Folha da Noite em 02/10/1933 na p. 2.

Crônica $\boldsymbol{O}$ dia de descanço. Publicada na Folha da Noite em 03/10/1933 na p. 2.

Crônica Um Boateiro. Publicada na Folha da Noite em 04/10/1933 na p. 2.

Crônica Economia Moderna. Publicada na Folha da Noite em 05/10/1933 na p. 2.

Crônica Doutrinas Econômicas. Publicada na Folha da Noite em 09/10/1933 na p. 2. E no livro Idéas de João Ninguém - 1935.

Crônica Há ou não há? Publicada na Folha da Noite em 10/10/1933 na p. 2.

Crônica Trapalhada. Publicada na Folha da Noite em 13/10/1933 na p. 2.

Crônica A Allemanha pregou um susto... Publicada na Folha da Noite em 17/10/1933 na p. 2.

Crônica A hora do vício. Publicada na Folha da Noite em 14/10/1933 na p. 2. E no livro Idéas de João Ninguém - 1935.

Crônica Madame faz compras. Publicada na Folha da Noite em 18/10/1933 na p. 2.

Crônica O Fascismo na Europa. Publicada na Folha da Noite em 19/10/1933 na p. 2.

Crônica $\boldsymbol{O}$ ‘caso’ da Alemanha. Publicada na Folha da Noite em 20/10/1933 na p. 2.

Crônica O Jornal e seus Annuncios. Publicada na Folha da Noite em 23/10/1933 na p. 2. E no livro Idéas de João Ninguém - 1935.

Crônica A Culpa do Chômage. Publicada na Folha da Noite em 24/10/1933 na p. 2. E no livro Idéas de João Ninguém - 1935. 
Crônica $\boldsymbol{O}$ “Negócio da China” do Japão. Publicada na Folha da Noite em 25/10/1933 na p. 2. E no livro Idéas de João Ninguém - 1935.

Crônica A Abyssínia e a Australia. Publicada na Folha da Noite em 26/10/1933 na p. 2.

Crônica Autonomias. Publicada na Folha da Noite em 30/10/1933 na p. 2.

Crônica Mercedes Simone. Publicada na Folha da Noite em 31/10/1933 na p. 2. E no livro Idéas de João Ninguém - 1935.

Crônica Coisas Brasileiras. Publicada na Folha da Noite em 01/11/1933 na p. 2.

Crônica Melodias Políticas. Publicada na Folha da Noite em 03/11/1933 na p. 2.

Crônica “As Liberdades Públicas”. Publicada na Folha da Noite em 06/11/1933 na p. 2.

Crônica História sem fim. Publicada na Folha da Noite em 07/11/1933 na p. 2.

Crônica A Constituinte e a Autonomia. Publicada na Folha da Noite em 08/11/1933 na p. 2.

Crônica Fascismo. Publicada na Folha da Noite em 09/11/1933 na p. 2.

Crônica Desarmamentos... Publicada na Folha da Noite em 10/11/1933 na p. 2.

Crônica “Pelo divórcio”. Publicada na Folha da Noite em 11/11/1933 na p. 2.

Crônica Os Paulistas e a Guerra. Publicada na Folha da Noite em 14/11/1933 na p. 2.

Crônica A camisa e o frack. Publicada na Folha da Noite em 16/11/1933 na p. 2.

Crônica “Port-Tarrascon”. Publicada na Folha da Noite em 20/11/1933 na p. 2. E no livro Idéas de João Ninguém - 1935.

Crônica Falta de Memória. Publicada na Folha da Noite em 17/11/1933 na p. 2.

Crônica A Melodia. Publicada na Folha da Noite em 18/11/1933 na p. 2.

Crônica O Heróe Nacional. Publicada na Folha da Noite em 21/11/1933 na p. 2. E no livro Idéas de João Ninguém - 1935.

Chronica Eqüestre. Publicada na Folha da Noite em 22/11/1933 na p. 2. E no livro Idéas de João Ninguém - 1935.

Crônica Divagações. Publicada na Folha da Noite em 23/11/1933 na p. 2.

Crônica Subscripção. Publicada na Folha da Noite em 25/11/1933 na p. 2. E no livro Idéas de João Ninguém - 1935.

Crônica A próxima guerra. Publicada na Folha da Noite em 27/11/1933 na p. 2.

Crônica Economias. Publicada na Folha da Noite em 28/11/1933 na p. 2.

Crônica Os Paisanos Paulistas. Publicada na Folha da Noite em 29/11/1933 na p. 2.

Crônica O Evadido da Liberdade. Publicada na Folha da Noite em 02/12/1933 na p. 2. E no livro Idéas de João Ninguém - 1935.

Crônica Novidades linguísticas. Publicada na Folha da Noite em 04/12/1933 na p. 2.

Crônica Realidade e sonho. Publicada na Folha da Noite em 05/12/1933 na p. 2.

Crônica Coisas da vida. Publicada na Folha da Noite em 06/12/1933 na p. 2.

Crônica Vício e Virtude. Publicada na Folha da Noite em 07/12/1933 na p. 2. E no livro Idéas de João Ninguém - 1935. 
Crônica Os planos econômicos. Publicada na Folha da Noite em 08/12/1933 na p. 2.

Crônica O Crâneo do rei Makáua. Publicada na Folha da Noite com o nome Artigo 246 do Tratado de Versalhes em 11/12/1933 - na p. 2. E no livro Idéas de João Ninguém - 1935.

Crônica A differença. Publicada na Folha da Noite em 12/12/1933 na p. 2.

Crônica Capítulo grammatical. Publicada na Folha da Noite em 13/12/1933 na p. 2.

Crônica Coisas da Assembléia. Publicada na Folha da Noite em 20/12/1933 na p. 2.

Crônica Morrer por Morrer. Publicada na Folha da Noite em 21/12/1933 na p. 2. E no livro Idéas de João Ninguém - 1935.

Crônica O famigerado cacho de bananas. Publicada na Folha da Noite em 22/12/1933 na p. 2.

Crônica Os Camellos. Publicada na Folha da Noite em 23/12/1933 na p. 2. E no livro Idéas de João Ninguém - 1935.

Crônica Esquerda e Direita. Publicada na Folha da Noite em 27/12/1933 na p. 2. E no livro Idéas de João Ninguém - 1935.

Crônica Esterilização. Publicada na Folha da Noite em 28/12/1933 na p. 2.

Crônica Necrologios. Publicada na Folha da Noite em 29/12/1933 na p. 2.

Crônica Ainda a Esterilização. Publicada na Folha da Noite em 02/01/1934 na p. 2.

Crônica Coisas Extravagantes. Publicada na Folha da Noite em 03/01/1934 na p. 2.

Crônica Prophecias. Publicada na Folha da Noite em 04/01/1934 na p. 2.

Crônica A “Próxima” Guerra. Publicada na Folha da Noite em 05/01/1934 na p. 2. E no livro Idéas de João Ninguém - 1935.

Crônica Sahir e Cahir. Publicada na Folha da Noite em 06/01/1934 na p. 2.

Crônica Humorismo. Publicada na Folha da Noite em 09/01/1934 na p. 2.

Crônica Salvando a Pátria. Publicada na Folha da Noite em 11/01/1934 na p. 2.

Crônica A Mágica. Publicada na Folha da Noite em 12/01/1934 na p. 2.

Crônica Ainda a “melodia”. Publicada na Folha da Noite em 16/01/1934 na p. 2.

Crônica Um homem honesto. Publicada na Folha da Noite em 15/01/1934 na p. 2.

Crônica A Alta Silésia, o Sarre e Salomão. Publicada na Folha da Noite em 17/01/1934 na p. 2. E no livro Idéas de João Ninguém - 1935.

Crônica A Minha Solução. Publicada na Folha da Noite em 19/01/1934 na p. 2.

Crônica A subida do morro... Publicada na Folha da Noite em 20/01/1934 na p. 2.

Crônica A tragédia de Cuba. Publicada na Folha da Noite em 23/01/1934 na p. 2.

Crônica Solução milagrosa. Publicada na Folha da Noite em 24/01/1934 na p. 2.

Crônica Carta Aberta a Anchieta, Ramalho e Teberyçá. Publicada na Folha da Noite em 25/01/1934 na p. 2.

Crônica Os assyrios. Publicada na Folha da Noite em 27/01/1934 na p. 2.

Crônica A secca nas finanças. Publicada na Folha da Noite em 30/01/1934 na p. 2. 
Crônica “França, desperta!” Publicada na Folha da Noite em 31/01/1934 na p. 2. E no livro Idéas de João Ninguém - 1935.

Crônica Censura á Imprensa. Publicada na Folha da Noite em 01/02/1934 na p. 2.

Crônica Lamentável Engano. Publicada na Folha da Noite em 02/02/1934 na p. 2.

Crônica Drama Galináceo. Publicada na Folha da Noite em 03/02/1934 na p. 2. E no livro Idéas de João Ninguém - 1935.

Crônica Ainda a Censura. Publicada na Folha da Noite em 05/02/1934 na p. 2.

Crônica O Interventor e o Dictador. Publicada na Folha da Noite em 06/02/1934 na. p. 2.

Crônica Carta Aberta ao prof. Desiderius Paap. Publicada na Folha da Noite em 08/02/1934 na p. 2. E no livro Idéas de João Ninguém - 1935.

Crônica A Sexta Arma. Publicada na Folha da Noite em 09/02/1934 na p. 2.

Crônica Véspera de Carnaval. Publicada na Folha da Noite em 10/02/1934 na p. 2.

Crônica Arrependimento. Publicada na Folha da Noite em 15/02/1934 na p. 2.

Crônica Liberdade de Imprensa. Publicada na Folha da Noite em 16/02/1934 na p. 2.

Crônica Os Prêmios do Salon. Publicada na Folha da Noite em 17/02/1934 na p. 2.

Crônica Falta de Memória. Publicada na Folha da Noite em 20/02/1934 na p. 2.

Crônica O Equívoco. Publicada na Folha da Noite em 21/02/1934 na p. 2.

Crônica A Toda Pressa. Publicada na Folha da Noite em 22/02/1934 na p. 2.

Crônica De Braços Abertos. Publicada na Folha da Noite em 23/02/1934 na p. 2.

Crônica Hontem e Hoje. Publicada na Folha da Noite em 27/02/1934 na p. 2.

Crônica Coisas do Brasil. Publicada na Folha da Noite em 28/02/1934 na p. 2. E no livro Idéas de João Ninguém - 1935.

Crônica Analphabetismo. Publicada na Folha da Noite em 01/03/1934 na p. 2.

Crônica Thankgiving Day... Publicada na Folha da Noite em 02/03/1934 na p. 2.

Crônica A Sexta Arma. Publicada na Folha da Noite em 03/03/1934 na p. 2.

Crônica Coisas da vida. Publicada na Folha da Noite em 05/03/1934 na p. 2.

Crônica A Capital Federal. Publicada na Folha da Noite em 06/03/1934 na p. 2.

Crônica Disciplina Partidária. Publicada na Folha da Noite em 07/03/1934 na p. 2.

Crônica Á Moda do “Lampeão”. Publicada na Folha da Noite em 09/03/1934 na p. 2.

Crônica É Prohibido Casar! Publicada na Folha da Noite em 12/03/1934 na p. 2. E no livro Idéas de João Ninguém - 1935.

Crônica “Flying down to... Havana”. Publicada na Folha da Noite em 14/03/1934 na p. 2.

Crônica O Filme em Relevo. Crônica Publicada na Folha da Noite em 16/03/1934 na p. 2.

Crônica O Caso de Princeza. Publicada na Folha da Noite em 20/03/1934 na p. 2.

Crônica Coisas da Assembléa. Crônica Publicada na Folha da Noite em 21/03/1934 na p. 2.

Crônica As Quatro Gerações. Publicada na Folha da Noite em 23/03/1934 na p. 2.

Crônica Pague e não bufe! Publicada na Folha da Noite em 26/03/1934 na p. 2. 
Crônica A única differença. Publicada na Folha da Noite em 27/03/1934 na p. 2.

Crônica A horripilante chacina. Publicada na Folha da Noite em 28/03/1934 na p. 2.

Crônica O silêncio é de ouro. Publicada na Folha da Noite em 29/03/1934 na p. 2.

Crônica A Trombeta de Josaphat. Publicada na Folha da Noite em 03/04/1934 na p. 2. E no livro Idéas de João Ninguém - 1935.

Crônica Não bulam que é peor! Publicada na Folha da Noite em 04/04/1934 na p. 2.

Crônica Os Homens Fortes. Publicada na Folha da Noite em 06/04/1934 na p. 2.

Crônica Please don't disturb! Publicada na Folha da Noite em 09/04/1934 na p. 2.

Crônica $\boldsymbol{O}$ ‘Assíduo Leitor’. Publicada na Folha da Noite em 12/04/1934 na p. 2.

Crônica O Homem Forte. Publicada na Folha da Noite em 13/04/1934 na p. 2.

Crônica Singularidades... Publicada na Folha da Noite em 16/04/1934 na p. 2.

Crônica Trapalhada Completa. Publicada na Folha da Noite em 17/04/1934 na p. 2.

Crônica Esses Amigos... Publicada na Folha da Noite em 18/04/1934 na p. 2.

Crônica O Cyclone e a Cabine. Publicada na Folha da Noite em 20/04/1934 na p. 2.

Crônica Os Equivocados. Publicada na Folha da Noite em 26/04/1934 na p. 2.

Crônica Staviskysmo. Publicada na Folha da Noite em 27/04/1934 na p. 2.

Crônica “Gleichschaltung”. Publicada na Folha da Noite em 30/04/1934 na p. 2. E no livro Idéas de João Ninguém - 1935.

Crônica Bônus, cambiaes e etc. Publicada na Folha da Noite em 01/05/1934 na p. 2.

Crônica Liberalismo e Liberalidade. Publicada na Folha da Noite em 02/05/1934 na p. 2.

Crônica Gente idônea. Publicada na Folha da Noite em 03/05/1934 na p. 2.

Crônica Não foi nada... Publicada na Folha da Noite em 04/05/1934 na p. 2.

Crônica Sommar e Subtrahir. Publicada na Folha da Noite em 08/05/1934 na p. 2.

Crônica Viva a Burrice! Publicada na Folha da Noite em 09/05/1934 na p. 2.

Crônica Idéas Salvadoras. Publicada na Folha da Noite em 10/05/1934 na p. 2.

Crônica Illusão e Realidade. Publicada na Folha da Noite em 11/05/1934 na p. 2. E no livro Idéas de João Ninguém - 1935.

Crônica O leite e o cavallo. Publicada na Folha da Noite em 14/05/1934 na p. 2.

Crônica “Amicus ignotus...” Publicada na Folha da Noite em 18/05/1934 na p. 2.

Crônica Os Equívocos. Publicada na Folha da Noite em 19/05/1934 na p. 2. E no livro Idéas de João Ninguém - 1935.

Crônica A hora do ajuste. Publicada na Folha da Noite em 21/05/1934 na p. 2.

Crônica Pedagogos Universitários. Publicada na Folha da Noite em 22/05/1934 na p. 2.

Crônica Prophylaxia, radio e etc. Publicada na Folha da Noite em 28/05/1934 na p. 2.

Crônica De onde vem a vida? Publicada na Folha da Noite em 31/05/1934 na p. 2.

Crônica Unidade Nacional. Publicada na Folha da Noite em 01/06/1934 na p. 2. E no livro Idéas de João Ninguém - 1935. 
Crônica Uma História Singular. Publicada na Folha da Noite em 02/06/1934 na p. 2. E no livro Idéas de João Ninguém - 1935.

Crônica Uma These Perigosa. Publicada na Folha da Noite em 05/06/1934 na p. 2.

Crônica Conversa na rua. Publicada na Folha da Noite em 06/06/1934 na p. 2.

Crônica Um caso como muitos. Publicada na Folha da Noite em 07/06/1934 na p. 2.

Crônica Os Homens Supersticiosos. Publicada na Folha da Noite em 08/06/1934 na p. 2. E no livro Idéas de João Ninguém - 1935.

Crônica Amnistia, Demétrio e cia. Publicada na Folha da Noite em 09/06/1934 na p. 2.

Crônica “Nós, os laranjas...” Publicada na Folha da Noite em 11/06/1934 na p. 2.

Crônica Contra São Paulo! Publicada na Folha da Noite em 13/06/1934 na p. 2.

Crônica Hortographias... Publicada na Folha da Noite em 14/06/1934 na p. 2.

Crônica “Morrer por amor...” Publicada na Folha da Noite em 15/06/1934 na p. 2. E no livro Idéas de João Ninguém - 1935.

Crônica A Confusão. Publicada na Folha da Noite em 18/06/1934 na p. 2.

Crônica Coisas Sérias da Assembléa. Publicada na Folha da Noite em 25/06/1934 na p. 2. E no livro Idéas de João Ninguém - 1935.

Crônica Paz e Amor. Publicada na Folha da Noite em 03/07/1934 na p. 2.

Crônica 11 ks. por Hora. Publicada na Folha da Noite em 05/07/1934 na p. 2.

Crônica O Separatismo. Publicada na Folha da Noite em 06/07/1934 na p. 2.

Crônica Desarmar e armar. Publicada na Folha da Noite em 10/07/1934 na p. 2.

Crônica O Torpedo Dirigido. Publicada na Folha da Noite em 11/07/1934 na p. 2.

Crônica Um Grande Cerimonial. Publicada na Folha da Noite em 12/07/1934 na p. 2.

Crônica Os 4.000 contos. Publicada na Folha da Noite em 13/07/1934 na p. 2.

Crônica O Bode Expiatório. Publicada na Folha da Noite em 17/07/1934 na p. 2.

Crônica Continuidades... Publicada na Folha da Noite em 18/07/1934 na p. 2.

Crônica Uma Boa Piada! Publicada na Folha da Noite em 19/07/1934 na p. 2.

Crônica Explorações... Publicada na Folha da Noite em 21/07/1934 na p. 2.

Crônica A Coragem de Votar. Publicada na Folha da Noite em 24/07/1934 na p. 2.

Crônica Retribuindo Visitas. Publicada na Folha da Noite em 25/07/1934 na p. 2.

Crônica E Agora? Publicada na Folha da Noite em 28/07/1934 na p. 2.

Crônica Os Máus Alumnos. Publicada na Folha da Noite em 30/07/1934 na p. 2. E no livro Idéas de João Ninguém - 1935.

Crônica Mais uma... Publicada na Folha da Noite em 01/08/1934 na p. 2.

Crônica As duas guardas. Publicada na Folha da Noite em 02/08/1934 na p. 2.

Crônica A Dictadura Partidária. Publicada na Folha da Noite em 07/08/1934 na p. 2.

Crônica A Criança de Rabo. Publicada na Folha da Noite em 09/08/1934 na página 2. E no livro Idéas de João Ninguém - 1935. 
Crônica Sendo possível, sim... Publicada na Folha da Noite em 14/08/1934 na p. 2.

Crônica Coisas da Vida. Publicada na Folha da Noite em 18/08/1934 na p. 2. E no livro Idéas de João Ninguém - 1935.

Crônica O ‘jornal do Recife’ e eu. Publicada na Folha da Noite em 21/08/1934 na p. 2.

Crônica O Tabú. Publicada na Folha da Noite em 24/08/1934 na p. 2.

Crônica Nós e elles. Publicada na Folha da Noite em 31/08/1934 na p. 2.

Crônica A Carioca. Publicada na Folha da Noite em 03/09/1934 na p. 2.

Crônica Um estrillo dramatico. Publicada na Folha da Noite em 08/09/1934 na p. 2.

Crônica O Japão de Pierre Loti. Publicada na Folha da Noite em 13/09/1934 na página 2. E no livro Idéas de João Ninguém - 1935.

Crônica O Perigo Amarello. Publicada na Folha da Noite em 19/09/1934 na página 2. E no livro Idéas de João Ninguém - 1935.

Crônica A Descoberta de Fawcett. Publicada na Folha da Noite em 23/10/1934 na p. 2.

Crônica A Espada da Noiva. Publicada na Folha da Noite em 24/10/1934 na p. 2.

Crônica De papo pr'o ar... Publicada na Folha da Noite em 26/10/1934 na p. 2.

Crônica O Grande Problema. Publicada na Folha da Noite em 29/10/1934 na p. 2.

Crônica Podia ser peór... Publicada na Folha da Noite em 31/10/1934 na p. 2.

Crônica Os “Profiteurs”. Publicada na Folha da Noite em 05/11/1934 na p. 2. E no livro Idéas de João Ninguém - 1935.

Crônica Getúlio usurpador! Publicada na Folha da Noite em 06/11/1934 na p. 2.

Crônica Os Bandeirantes Rhenanos. Publicada na Folha da Noite em 15/11/1934 na p. 2. E no livro Idéas de João Ninguém - 1935.

Crônica Um estrillo itapolitano. Publicada na Folha da Noite em 16/11/1934 na p. 2.

Crônica Em defesa da moral! Publicada na Folha da Noite em 19/11/1934 na p. 2.

Crônica O algodão e a nudez. Publicada na Folha da Noite em 21/11/1934 na p. 2.

Crônica O drama dos jardinenses. Publicada na Folha da Noite em 28/11/1934 na p. 2.

Crônica Conto de Natal. Publicada na Folha da Noite em 11/12/1934 na p. 2. E no livro Idéas de João Ninguém - 1935.

Crônica A “primeira pedra”... Publicada na Folha da Noite em 22/12/1934 na p. 2.

Crônica Schlagt Hitler! Publicada na Folha da Noite em 26/12/1934 na p. 2.

Crônica Assistência á infância. Publicada na Folha da Noite em 28/12/1934 na p. 2.

Crônica Idéas de um homem prático. Publicada na Folha da Noite em 03/01/1934 e no livro Idéas de João Ninguém - 1935.

Crônica Igualdade dos Sexos. Publicada na Folha da Noite em 04/01/1935 na p. 2. E no livro Idéas de João Ninguém - 1935.

Crônica We don't do our part. Publicada na Folha da Noite em 09/01/1935 na p. 2.

Crônica A guerra contra São Paulo. Publicada na Folha da Noite em 11/0/1935 na p. 2. 
Crônica Petição. Publicada na Folha da Noite em 18/01/1935 na p. 2.

Crônica Coisas Alarmantes. Publicada na Folha da Noite em 24/01/1935 na p. 2.

Crônica Terêtete-lá vae fogo! Publicada na Folha da Noite em 28/01/1935 na p. 2.

Crônica O drama escolar. Publicada na Folha da Noite em 30/01/1935 na p. 2.

Crônica Coisas do Século. Publicada na Folha da Noite em (?) e no livro Idéas de João Ninguém 1935.

Crônica Saias Abaixo! Publicada na Folha da noite em (?) e no livro Idéas de João Ninguém - 1935.

Crônica Médicos e Curandeiros. Publicada na Folha da Noite em 05/02/1935 na p. 2.

Crônica O jiu-jitsu do sacerdote. Publicada na Folha da Noite em 06/02/1935 na p. 2.

Crônica ‘Ora, o Xavier’. Publicada na Folha da Noite em 08/02/1935 na p. 2.

Crônica A guerra contra S. Paulo. Publicada na Folha da Noite em 11/02/1935 na p. 2.

Crônica Política e Cinema. Publicada na Folha da Noite em 13/02/1935 na p. 2.

Crônica Um pouco de Urbanismo. Publicada na Folha da Noite em 14/02/1935 na p. 2.

Crônica O Viaducto e a ladeira. Publicada na Folha da Noite em 18/02/1935 na p. 2.

Crônica O Ovo de Colombo. Publicada na Folha da Noite em 20/02/1935 na p. 2.

Crônica O drama do café. Publicada na Folha da Noite em 22/02/1935 na p. 2.

Crônica O Peccado. Publicada na Folha da Noite em 07/03/1935 na p. 2.

Crônica O armamentismo allemão. Publicada na Folha da Noite em 23/03/1935 na p. 2.

Crônica Sobre a nudez forte... Publicada na Folha da Noite em 28/03/1935 na p. 2.

Crônica A República Dual. Publicada na Folha da Noite em 02/04/1935 na p. 2.

Crônica O direito de viver. Publicada na Folha da Noite em 04/04/1935 na p. 2.

Crônica O grande espectaculo. Publicada na Folha da Noite em 05/04/1935 na p. 2.

Crônica Falta de assumpto. Publicada na Folha da Noite em 08/04/1935 na p. 2.

Crônica O Museu Ethnographico. Publicada na Folha da Noite em 10/04/1935 na p. 2.

Crônica “Devo que não pagarei...” Publicada na Folha da Noite em 12/04/1935 na p. 2.

Crônica Gastão Formenti. Publicada na Folha da Noite em 18/04/1935 na p. 2.

Crônica “Debout, les vifs!” Publicada na Folha da Noite em 20/04/1935 na p. 2.

Crônica Pague e não bufe! Publicada na Folha da Noite em 23/04/1935 na p. 2.

Crônica Nudismos... Publicada na Folha da Noite em 24/04/1935 na p. 2.

Crônica Dos males o menor... Publicada na Folha da Noite em 25/04/1935 na p. 2.

\section{Outras Fontes Principais:}

Editoriais da Folha da Noite - 1933-1935. Publicados diariamente na página 2. 


\section{Outras Fontes:}

ANDRADE, Mario. Macunaíma (O herói sem nenhum caráter). 6a Edição. São Paulo: Martins, 1970.

FREYRE, Gilberto. Casa grande \& Senzala: formação da família brasileira sob o regime de economia patriarcal. $9^{a}$ Edição. Rio de Janeiro: José Olympio, 1958.

“Recenseamento Geral do Brasil - 1940”. Rio de Janeiro: IBGE, 1950, 243 p. v.18. In: Censo Demográfico: população e habitação.

SALGADO, Plínio. A Psicologia da Revolução. Rio de Janeiro: Civilização Brasileira, 1933.

SIMONSEN, Roberto Cochrane. Evolução Industrial do Brasil e outros estudos. São Paulo: Nacional/Editora da USP, 1973.

VARGAS, Getúlio. A Nova Política do Brasil. I - Da Aliança Liberal às realizações do primeiro ano de Governo - 1930-1931. Rio de Janeiro: José Olympio, 1938.

A Nova Política do Brasil. II - O ano de 1932. A Revolução e o Norte - 1933. Rio de Janeiro: José Olympio, 1938.

A Nova Política do Brasil. III - A realidade nacional em 1933. Retrospecto das realizações do Governo - 1934. Rio de Janeiro: José Olympio, 1938.

Textos da Ação Integralista Brasileira. In: CARONE, Edgard. A Segunda República (1930-1937). São Paulo: DIFEL, 1977. 


\section{Bibliografia}

\section{Obras de Belmonte:}

BELMONTE. Assim Falou Juca Pato. (aspectos divertidos de uma confusão dramática). São Paulo: Companhia Editora Nacional, 1933.

. Idéas de João Ninguém. Rio de Janeiro: José Olympio, 1935.

- No Tempo dos Bandeirantes. São Paulo: Departamento de Cultura da Prefeitura Municipal de São Paulo, 1939.

. Música, Maestro! São Paulo: Edição da Folha da Manhã, 1940.

. Brasil de Outrora (desenhos inspirados em Rugendas). São Paulo: Melhoramentos,

1944.

. Caricatura dos Tempos. São Paulo: Melhoramentos, 1948.

. No Tempo dos Bandeirantes. Com prefácio de Leonardo Arroyo. Coleção Paulística, vol. XX. São Paulo: Governo do Estado de São Paulo, 1980. Edição fac-similar.

\section{Obras sobre Belmonte:}

Belmonte Presente. São Paulo: Secretaria da Cultura, Ciência e Tecnologia - DACH - Comissão de Artes Plásticas - MASP, 1978.

CARVALL (Organizador). Belmonte 100 Anos. São Paulo: Senac, 1996.

LIMA, Herman. História da Caricatura no Brasil - volume IV. Rio de Janeiro: José Olympio, 1963, pp. 1362-1372.

NOGUEIRA, Andréa de Araújo. Um Juca na Cidade: representatividade do personagem criado por Belmonte na imprensa paulista (Folha da Manhã 1925-1927). São Paulo: IA-Unesp, 1999. (Dissertação de Mestrado)

SILVA, Marcos A . da: “A Guerra de Belmonte: humor gráfico e política no Brasil durante a segunda guerra mundial”, in: COGGIOLA, Osvaldo (org.). Segunda Guerra Mundial: um balanço histórico. São Paulo: Xamã/FFLCH-USP, 1995, pp. 337-348.

SILVA, Regina Helena Alves da. "Do Avesso, do Avesso, do Avesso, do Avesso”, in: São Paulo. A Invenção da Metrópole.São Paulo: FFLCH/USP, 1997. (Tese de Doutorado)

\section{Entrevistas e Artigos publicados em Jornais e Revistas:}

BELMONTE (pseud.). Vamos Ler!, 1 fev. 1945, p. 24-25.

BELMONTE (pseud.). “Entrevista com Belmonte”. Vamos Ler! No 13, set. 1945.

Entrevista concedida a Armando Pacheco. 
FLORENCE, Anatole. “Morreu Belmonte!” Folha da Manhã (São Paulo), 20 abr. 1947, p. 4.

PATI, Francisco. “O meu Amigo Belmonte”. Folha da Noite (São Paulo), 23 abr. 1947.

VAINER, Nelson. "Belmonte. Ao décimo aniversário do desaparecimento do grande artista." Correio da Manhã (Rio de Janeiro), 25 maio 1957. . "Vida e obra de Belmonte.” Folha da Noite (São Paulo), 25 abr. 1947.

\section{Obras sobre história, historiografia e imprensa (Brasil):}

ABREU, Marcelo de Paiva. “O Brasil e a Economia Mundial (1929-1945).” In: FAUSTO, Boris (org.). História Geral da Civilização Brasileira - Economia e Cultura (1930 - 1964) - volume IV. São Paulo: Difusão Européia do Livro, 1984.

ABUD, Kátia. O Sangue Intimorato e as Nobilíssimas Tradições (a construção de um símbolo paulista: o Bandeirante). São Paulo: DH-FFLCH-USP, 1985. (Tese de Doutorado)

ANDREUCCI, Álvaro Gonçalves Antunes; OLIVEIRA. Valeria Garcia (sob a coordenação e organização de Maria Luiza Tucci Carneiro). Cultura Amordaçada: intelectuais e músicos sob a vigilância do DEOPS. Inventário DEOPS Módulo VI - Comunistas. São Paulo: Arquivo do Estado/ Imprensa Oficial, 2002.

ANTONACCI, Maria Antonieta Martinez. A Vitória da Razão(?). O IDORT e a Sociedade Paulista. São Paulo: Marco Zero, 1993.

BECHELLI, Ricardo Sequeira. Metamorfoses na interpretação do Brasil - Tensões no paradigma racista). São Paulo: DH-FFLCH-USP, 2009. (Tese de Doutorado)

BEZERRA, Holien Gonçalves. O Jogo do Poder: revolução paulista de 32. São Paulo: Moderna, 1989.

BORGES, Vavy Pacheco. Getúlio Vargas e a Oligarquia Paulista: história de uma esperança e muitos desenganos. São Paulo: Brasiliense, 1979.

. Tenentismo e Revolução Brasileira. São Paulo: Brasiliense, 1992.

. Memória Paulista. São Paulo: EDUSP, 1997.

CANCELLI, Elizabeth. O Mundo da Violência: a polícia da Era Vargas. Brasília: Editora Universidade de Brasília, 1993.

CAPELATO, Maria Helena. O Movimento de 1932: a causa paulista. São Paulo: Brasiliense, 1981. . Os Arautos do Liberalismo. Imprensa Paulista (1920-1945). São Paulo: Brasiliense, 1989.

. Multidões em Cena: propaganda política no varguismo e no peronismo. Campinas/SP: Papirus, 1998.

CAPELATO, Maria Helena; PRADO, Maria Lígia. O Bravo Matutino (Imprensa e ideologia no jornal “O Estado de São Paulo”). São Paulo: Alfa-Omega, 1980. 
CARNEIRO, Maria Luiza Tucci. O Anti-semitismo na Era Vargas: fantasmas de uma geração (1930-1945). $2^{\circ}$ ed. São Paulo: Brasiliense, 1995.

. “O Estado Novo, o DOPS e a Ideologia da Segurança Nacional” In: Estado Novo: 60 anos. Rio de Janeiro: CPDOC / FGV (no prelo).

; KOSSOY, Boris (organizadores). A Imprensa confiscada pelo DEOPS: 1924-1954. São Paulo: Ateliê Editorial/Imprensa Oficial do Estado de São Paulo/Arquivo do Estado, 2003.

CARONE, Edgard. A República Nova (1930-1937). 3ª edição. São Paulo: Difusão Européia do Livro, 1982.

CARVALHO, José Murilo de. A Formação das Almas: o Imaginário da República no Brasil. São Paulo: Companhia das Letras, 2002.

CERRI, Luis Fernando. "NON DUCOR, DUCO: A Ideologia da Paulistanidade e a Escola”. In: Revista Brasileira de História. São Paulo: Volume 18, número 36, 1998.

CHASIN, José. "Sob a Égide da AIB”. In: O Integralismo de Plínio Salgado. Forma de regressividade no capitalismo hiper-tardio. São Paulo: Livraria Ciências Humanas, 1978.

. "Premissas, Conclusões e Futuras Aproximações”. In: O Integralismo de Plínio Salgado.

Forma de regressividade no capitalismo hiper-tardio. São Paulo: Livraria Ciências Humanas, 1978.

COHEN, Ilka Stern. Bombas sobre São Paulo: a Revolução de 1924. São Paulo: UNESP, 2007.

“A Paulicéia Atacada”. In: História Viva. São Paulo: Duetto, volume 57, (07), 2008.

Disponível em: http://www2.uol.com.br/historiaviva/reportagens/a_pauliceia_atacada.html

DE PAULA, Jeziel. 1932 - Imagens Construindo a História. Campinas/SP: Editora da UNICAMP/Editora UNIMESP, 1999.

DEAN, Warren. A Industrialização de São Paulo (1880-1945). São Paulo: DIFEL [s/d].

DECCA, Edgar de. 1930: O Silêncio dos Vencidos. São Paulo: Brasiliense, 1983.

DIWAN, Pietra. “Eugenia, a biologia como farsa”. In: História Viva. São Paulo: Duetto, volume 49, (11), 2007. Disponível em:

http://www2.uol.com.br/historiaviva/reportagens/eugenia_a_biologia_como_farsa.html

DONATO, Hernâni. A Revolução de 32. São Paulo: Círculo do Livro, 1982.

FAORO, Raimundo. Existe um Pensamento Político Brasileiro? São Paulo: Editora Ática, 1994.

. Os Donos do Poder: formação do patronato político brasileiro - Vol. II. São Paulo: Globo/ Publifolha, 2000.

FAUSTO, Boris. A Revolução de 1930 (historiografia e história). São Paulo: Brasiliense, 1976. “A Crise dos Anos Vinte e a Revolução de 1930.”, in: FAUSTO, Boris (org.). História Geral da Civilização Brasileira - Sociedade e Instituições (1889-1930) - Volume II. São Paulo: Difusão Européia do Livro, 1984, pp. 402-426.

FERREIRA, Antonio Celso. A Epopéia Bandeirante: letrados, instituições, invenção histórica (1870-1940). São Paulo: Editora UNESP, 2002. 
FERRETTI, Danilo José Zioni. A Construção da Paulistanidade. Identidade, Historiografia e Política em São Paulo (1856-1930). São Paulo: DH-FFLCH-USP, 2004. (Tese de Doutorado)

FONSECA, Sherloma Starlet. "Memórias de Paulo Duarte: momentos da escrita e luta antigetulista”. In: Revista Espaço Acadêmico. Maringá: UEM, volume 82, (3), 2008.

Disponível em: http://www.espacoacademico.com.br/082/82fonseca.htm. Acesso em 13.abr. 2008.

FRANCO, Maria Sylvia de Carvalho. “All the Words was America”, In: Revista USP, Dossiê Liberalismo e Escravidão. São Paulo: Universidade de São Paulo, n. 17, 1993, pp. 30-53.

FURTADO, Celso. Formação Econômica do Brasil. São Paulo: Companhia Editora Nacional / Publifolha, 2000.

GALDINO, Luiz. 1932: a guerra dos paulistas. São Paulo: Editora Ática, 1996.

GOLDENSTEIN, Gisela Taschner. Folhas ao vento: contribuição ao estudo da indústria cultural no Brasil. Tese de Doutorado, FFLCH/USP. São Paulo: datiloscrito, 1986.

GOMES, Ângela Maria de Castro. "Confronto e Compromisso no Processo de Constitucionalização (1930-1935)”, In: FAUSTO, Boris (org.). História Geral da Civilização Brasileira - Sociedade e política (1930 - 1964) - volume III. São Paulo: Difusão Européia do Livro, 1984, pp. 09-75.

- “Ideologia e Trabalho no Estado Novo”, in: PANDOLFI, Dulce (organizadora). Repensando o Estado Novo. Rio de Janeiro: FGV, 1999, pp. 53-72.

LENHARO, Alcir. Sacralização da Política. Campinas/SP: Editora da UNICAMP/ Papirus, 1986.

LEVINE, Robert M. O Regime de Vargas (os anos críticos, 1934-1938). Rio de Janeiro: Nova Fronteira, 1980.

. Pai dos Pobres? O Brasil e a Era Vargas. São Paulo: Companhia das Letras, 2001.

LIMA, Sandra Lúcia Lopes. "Imprensa feminina, Revista feminina. A imprensa feminina no Brasil”, in: Projeto História. São Paulo: PUC/SP, 35: 221/241, dez 2007.

LOVE, Joseph. São Paulo na Federação Brasileira (1889-1937). Rio de Janeiro: Paz e Terra, 1982

LUCA, Tânia Regina de. A Revista do Brasil: Um Diagnóstico para a (N)ação. São Paulo: Fundação Editora da UNESP, 1999.

MALUF, Marina e MOTT, Maria Lúcia. "Recônditos do Mundo Feminino”, in: SEVCENKO, Nicolau (org.). História da Vida Privada no Brasil - República: da Belle Époque à Era do Rádio volume III. São Paulo : Companhia das Letras, 1998, pp. 367-421.

MORSE, Richard. Formação Histórica de São Paulo: de comunidade a metrópole. São Paulo: DIFEL, 1970.

MOTA, Carlos Guilherme da. Ideologia da Cultura Brasileira (1933-1974). São Paulo: Editora Ática, 1977.

MOTA, Carlos Guilherme e CAPELATO. Maria Helena. História da Folha de São Paulo (19211981). São Paulo: IMPRES, 1980. 
PINHEIRO, Paulo Sérgio. "Classes Médias Urbanas: formação, natureza, intervenção na vida política.” In: FAUSTO, Boris (org.). História Geral da Civilização Brasileira - Sociedade e Instituições (1889-1930) - Tomo III / Volume II. Rio de Janeiro: Bertrand Brasil, 1997, pp. 09-37.

PIRES, Elaine Muniz. Imprensa, Ditadura e Democracia: a construção da auto-imagem dos jornais do grupo Folhas (1978/2004). São Paulo: PUC/SP, 2008. (Dissertação de Mestrado)

PRADO, Maria Lígia Coelho. A Democracia Ilustrada (O Partido Democrático de São Paulo, 19261934). São Paulo: Editora Ática, 1986.

RAFFAINI, Patrícia Tavares. Esculpindo a Cultura na Forma Brasil. O Departamento de Cultura de São Paulo (1935-1938). São Paulo: Humanitas/FFLCH-USP, 2001.

REIS FILHO, Daniel Aarão. Uma Revolução Perdida - a história do socialismo soviético. São Paulo: Perseu Abramo, 1997.

SAES, Décio. “Classe Média e Sistema Político no Brasil 1930-1964”, in: FAUSTO, Boris (org.). História Geral da Civilização Brasileira - Sociedade e Política (I930 - 1964) - volume III. São Paulo: Difusão Européia do Livro, 1984, pp. 449-521.

. Classe Média e Sistema Político no Brasil. São Paulo: T. A . Queiroz, 1984.

SALIBA, Elias Thomé. “A Dimensão Cômica na Vida Privada na República”, in: SEVCENKO, Nicolau (org.). História da Vida Privada no Brasil - República: da Belle Époque à Era do Rádio volume III. São Paulo : Companhia das Letras, 1998, pp. 289-365.

. Raízes do Riso. A representação humorística na história brasileira: da Belle Époque aos primeiros tempos do rádio. São Paulo: Companhia das Letras, 2002.

SEVCENKO, Nicolau. Orfeu Extático na Metrópole. São Paulo, sociedade e cultura nos frementes anos 20. São Paulo: Companhia das Letras, 2003.

SCHWARCZ, Lilia Moritz. "Nem preto nem branco, muito pelo contrário”, in: SCHWARCZ, Lilia Moritz (Org.). Contrastes da intimidade contemporânea. São Paulo: Cia. das Letras, 1998. (História da vida privada no Brasil - 4).

SILVA, Helio e CARNEIRO, Maria Cecília Ribas. História da República Brasileira. São Paulo: Editora Três, 1975.

SILVA, Marcos A. da. Caricata República. Zé Povo e o Brasil. São Paulo: Marco Zero/CNPq, 1990. . Prazer e Poder do Amigo da Onça. São Paulo: Paz e Terra, 1996.

. Rir das Ditaduras. Os Dentes de Henfil (Ensaios sobre Fradim - 1971/1980). Tese de Livredocência apresentada à FFLCH/USP. São Paulo: digitado, 2000.

SILVA, Regina Helena Alves da. São Paulo. A Invenção da Metrópole. São Paulo: FFLCH-USP, 1997. (Tese de Doutorado)

SILVA, Zélia Lopes da. A Domesticação dos Trabalhadores nos Anos 30. São Paulo: Marco Zero/ CNPQ, 1991.

A República dos Anos 30. A Sedução do Moderno. Novos atores em cena: industriais e trabalhadores na Constituinte de 1933-1934. Londrina: Editora da UEL, 1999. 
SINGER, Paul. Desenvolvimento Econômico e Evolução Urbana (análise da evolução econômica de São Paulo, Blumenau, Porto Alegre, Belo Horizonte e Recife). São Paulo: Companhia Editora nacional/ EDUSP, 1968.

SODRÉ, Nélson Werneck. O que se deve ler para conhecer o Brasil. Rio de Janeiro: Centro Brasileiro de Pesquisas Educacionais e Ministério da Educação, 1960.

História da Imprensa no Brasil. Rio de Janeiro: Civilização Brasileira, 1966.

TAKEUCHI, Marcia Yumi. O Perigo Amarelo. Imagens do Mito, Realidade do Preconceito (19201945). São Paulo: DH-FFLCH-USP, 2004. (Dissertação de Mestrado)

TRINDADE, Hélgio. Integralismo: O Fascismo Brasileiro da Década de 30. São Paulo/ Porto Alegre: Difusão Européia do Livro/ URGS, 1974.

TRONCA, Ítalo. Revolução de 30: a dominação oculta. São Paulo: Brasiliense, 1985.

VELLOSO, Monica Pimenta. Modernismo no Rio de Janeiro - Turunas e Quixotes. São Paulo: Fundação Getúlio Vargas [s/d.].

“A Brasilidade Verde-Amarela: nacionalismo e regionalismo paulista”, in: Revista Estudos Históricos. Rio de Janeiro: volume 6, (11), 1993.

Disponível em: http://www.cpdoc.fgv.br/revista/arq/116.pdf . Acesso em: 10-jan. 2007.

Que Cara tem o Brasil? As maneiras de pensar e sentir o nosso país. Rio de Janeiro:

Ediouro, 2000.

VESENTINI, Carlos Alberto. A Teia do Fato: uma proposta de estudo sobre a memória histórica. São Paulo: HUCITEC, 1997.

VIANNA, Marly de Almeida Gomes. Revolucionários de 1935: sonho e realidade. São Paulo: Expressão Popular, 2007.

\section{Obras sobre cultura e linguagens (Brasil):}

ANAN, Sylvia Tamie. Crônica da vida inteira: memórias da infância nas crônicas de Manuel Bandeira. São Paulo: FFLCH-USP, 2006. (Dissertação de Mestrado)

ARÊAS, Vilma. Iniciação à Comédia. Rio de Janeiro: Jorge Zahar, 1990.

ARRIGUCCI JÚNIOR, Davi. “Fragmentos sobre a Crônica”, in: Enigma e Comentário. São Paulo: Companhia das Letras, 2001, pp. 51-66.

BOSI, Alfredo. História Concisa da Literatura Brasileira. São Paulo: Cultrix, 1967.

BRAIT, Beth (organizadora). Bakhtin: dialogismo e construção do sentido. Campinas, SP: Editora Unicamp, 2006.

CANDIDO, Antonio. Dialética da Malandragem. In: Revista do Instituto de Estudos Brasileiros, São Paulo: $n^{\circ}$ 08, 1970.

. “A vida ao rés-do-chão”, in: ANDRADE, Carlos Drummond de et alii. Para gostar de ler: crônicas. São Paulo: Editora Ática, 1979, pp.5-13. 
"Prefácio” a CHASIN, José. O Integralismo de Plínio Salgado. Forma de regressividade no capitalismo hiper-tardio. São Paulo: Livraria Ciências Humanas, 1978, pp. 13-20.

. A Educação pela Noite e outros ensaios. São Paulo: Editora Ática, 1989.

Literatura e Sociedade. São Paulo: Globo/Publifolha, 2000.

CHAUÍ, Marilena. “Apontamentos para uma Crítica da Ação Integralista Brasileira”, in: FRANCO, Maria Sylvia Carvalho. Ideologia e Mobilização Popular. São Paulo: CEDEC/ Paz e Terra, 1978, pp.17-150.

. Conformismo e Resistência: aspectos da cultura popular no Brasil. São Paulo: Brasiliense, 1989.

. O que é Ideologia. São Paulo: Brasiliense, 2001.

. Brasil: mito fundador e sociedade autoritária. São Paulo: Perseu Abramo, 2006.

CHIARELLI, Tadeu. Um Jeca nos Vernissagens. São Paulo: EDUSP, 1995.

DUARTE, Rodrigo Antonio de Paiva. Adorno, Horkheimer \& A Dialética do Esclarecimento. $2^{\mathrm{a}}$ edição. Rio de Janeiro: Jorge Zahar, 2004.

GAGNEBIN, Jeanne Marie. "Memória e Libertação”, in: Walter Benjamin. Coleção Encanto Radical. São Paulo: Brasiliense, 1982.

. “Walter Benjamin. Memória, história e narrativa”, in: Mente/Cérebro \& Filosofia. São

Paulo: Duetto, volume 7, 2007, pp. 59-67.

GUINSBURG, Jacó. (org.). O Expressionismo. São Paulo: Perspectiva, 2002.

GINZBURG, Jaime. “Conceito de Melancolia”, in: Revista da Associação Psicanalítica de Porto Alegre, APPOA, v. 20, 2001.

. "Violência e Forma: notas em torno de Benjamin e Adorno”, disponível em:

http://www.abralic.org.br/enc2007/anais/54/1300.pdf.

LAFETÁ, João Luiz. 1930: a crítica e o modernismo. São Paulo: Duas Cidades/Editora 34, 2000.

LOBATO, José Bento Monteiro. A Chave do Tamanho. 11ª edição. São Paulo: Brasiliense, 1972.

MELO, Luís Correia de. Dicionário de Autores Paulistas. São Paulo: Comissão do IV Centenário da Cidade de São Paulo - Serviço de Comemorações Culturais, 1954.

MICELI, Sérgio. Intelectuais à Brasileira. São Paulo: Companhia das Letras, 2001.

REPA, Luís Sérgio. “Razão Instrumental e Declínio do Indivíduo.” In: Mente/Cérebro \& Filosofia. São Paulo: Duetto, volume 7, 2007, pp. 16-23.

RIBEIRO, João. O que é Positivismo. São Paulo: Brasiliense, 1994.

ROUANET, Paulo Sergio. As Razões do Iluminismo. São Paulo: Companhia das Letras, 1999. Mal-estar na Modernidade: ensaios. São Paulo: Companhia das Letras, 2003.

SÁ, Jorge de. A Crônica. São Paulo: Editora Ática, 2001. 
SELIGMANN-SILVA, Márcio. O Local da Diferença. Ensaios sobre memória, arte, literatura e tradução. São Paulo: Editora 34, 2000.

SORIA, Ana Carolina Soliva. "Dialética do Esclarecimento. A mortificação do homem”, in: Mente/Cérebro \& Filosofia. São Paulo: Duetto, volume 7, 2007, pp. 34-41.

TAVARES, Hênio Último. Teoria Literária. 10ª edição. Rio de Janeiro: Villa Rica Editoras, 1974.

\section{Outras obras:}

ADORNO, Theodor; HORKHEIMER, Max. “O Conceito de Esclarecimento”, in: Dialética do Esclarecimento: fragmentos filosóficos. Rio de Janeiro: Jorge Zahar, 1985, pp. 19-52.

ARENDT, Hannah. Origens do Totalitarismo. São Paulo: Companhia das Letras, 1989. . A Condição Humana. 10ª edição. Rio de Janeiro: Forense Universitária, 2007.

ARGAN, Giulio Carlo. Arte Moderna. Do Iluminismo aos Movimentos Contemporâneos. 9a edição. São Paulo: Companhia das Letras, 2004.

BACZKO, Bronislaw. "Imaginação Social”, in: Enciclopédia Einaudi - volume 5 - Anthroposhomem. Vila da Maia: Imprensa Nacional/Casa da Moeda, 1985, pp. 297-332.

BAKHTIN, Mikhail. Problemas da Poética de Dostoievski. 2a edição. Rio de Janeiro: Forense Universitária, 1981.

A cultura Popular na Idade Média e no Renascimento. O Contexto de François Rabelais. São Paulo-Brasília: Edunb/Hucitec, 1999.

BENJAMIN, Walter. Magia e Técnica, Arte e Política. Ensaios sobre literatura e história da cultura. Obras Escolhidas - Volume I. São Paulo: Brasiliense, 1985.

BERGSON, Henri. O Riso. São Paulo: Martins Fontes, 2001.

BERMAN, Marshall. Tudo que é Sólido Desmancha no Ar: a aventura da modernidade. São Paulo: Companhia das Letras, 1986.

CAPRETTINI, Gian Paolo. “Alegoria”, in: Enciclopédia Einaudi - volume 31 - Signo. Lisboa: Imprensa Nacional/Casa da Moeda, 1994, pp. 247-278.

DUMA, Jean. "Sobre as elites: abordagem historiográfica”, in: Revista História Unisinos. São Leopoldo: UNISINOS, volume 7, (8), 2003, pp. 89-103.

ECO, Humberto. “Metáfora”, in: Enciclopédia Einaudi - volume 31 - Signo. Lisboa: Imprensa Nacional/Casa da Moeda, 1994, pp. 200-246.

EINSTEIN, Albert e FREUD, Sigmund. Pourquoi la guerre? Correspondence entre Albert Einstein et Sigmund Freud. Versão editada por meio da iniciativa do Instituto Internacional de Cooperação Intelectual. Sociedade das Nações, 1933. Disponível em:

http://classiques.uqac.ca/classiques/freud_sigmund/freud.html

FREUD, Sigmund. “Os Chistes e sua Relação com o Inconsciente”, in: Obras psicológicas completas - volume VIII. Rio de Janeiro: Imago, 1977. 
. “Luto e Melancolia (1917) [1915]”, in: Obras psicológicas completas - volume XIV. Rio de Janeiro: Imago, 1977.

. "Para além do princípio de prazer (1920)”, in: Obras psicológicas completas - volume XVIII. Rio de Janeiro: Imago, 1977.

. O Mal-Estar na Civilização (1930 [1929])”, in: Obras psicológicas completas - volume XXI. Rio de Janeiro: Imago, 1977.

GINZBURG, Carlo. O Queijo e os Vermes: o cotidiano e as idéias de um moleiro perseguido pela inquisição. São Paulo: Companhia das Letras, 2002.

Mitos, Emblemas, Sinais: morfologia e história. São Paulo: Companhia das letras, 2003.

GIRARDET, Raoul. Mitos e Mitologias Políticas. São Paulo: Companhia das Letras, 1987.

GOMBRICH, Ernest H. História da Arte. São Paulo: Círculo do Livro/Zahar [s/d].

Meditações sobre um Cavalinho de Pau. São Paulo: EDUSP, 1999.

HEGEL, Georg. Estética - A Idéia e o Ideal. São Paulo: Abril Cultural, 1974.

. Estética - O Belo Artístico ou o Ideal. São Paulo: Abril Cultural, 1974.

HEIMANN, Paula. "Notas sobre a teoria dos instintos de vida e de morte”, in: Os Progressos da Psicanálise. 3a edição. Rio de Janeiro: Editora Guanabara, 1986, pp. 344-361.

HOBSBAWM, Eric. Ecos da Marselhesa. Dois séculos revêem a Revolução Francesa. São Paulo: Companhia das Letras, 1996.

. A Era dos Extremos. São Paulo: Companhia das Letras, 1998.

. A Era dos Impérios (1875-1914). $8^{\mathrm{a}}$ edição. São Paulo: Paz e Terra, 2003.

. A Era do Capital (1848-1875). Rio de Janeiro: Paz e Terra, 2002.

HOBSBAWM, Eric e RANGER, Terence. A Invenção das Tradições. Rio de Janeiro: Paz e Terra, 1984.

KLARK, Katerina e HOLQUIST, Michael. Mikhail Bakhtin. São Paulo: Perspectiva, 2004.

LE GOFF, Jacques. "Progresso/Reação”, in: Enciclopédia Einaudi - volume 1 - Memória-História. Porto: Imprensa Nacional/Casa da Moeda, 1984, pp. 338-369.

MARX, Karl. Manuscritos Econômico-filosóficos. São Paulo: Abril Cultural, 1974. . Introdução [à Crítica da Economia Política]. São Paulo: Abril Cultural, 1974.

MINOIS, Georges. História do Riso e do Escárnio. São Paulo: Editora UNESP, 2003.

PAXTON, Robert Owen. A Anatomia do Fascismo. São Paulo: Paz e Terra, 2007.

POLANYI, KARL. A Grande Transformação: as origens de nossa época. Rio de Janeiro: Campus, 2000.

POLIAKOV, Léon. O Mito Ariano. São Paulo: Perspectiva/Editora da Universidade de São Paulo, 1974.

PROPP, Vladimir. Comicidade e Riso. São Paulo: Editora Ática, 1993. 
QUINTILIANO, Fábio. “Du Rire”. In: Institution Oratoire (II - Livres IV-VI). Texte revu et traduit avec introduction et notes par Henri Bornecque. Paris: Librarie Garnier Fréres, [s.d.], pp. 327-373.

REICH, Wilhelm. Psicologia de Massa do Fascismo. São Paulo: Martins Fontes, [s/d]. . Escuta, Zé Ninguém! São Paulo: Martins Fontes, 1998.

REMARQUE, Erich Maria. Sin novedad em el frente. Barcelona: Printer, [s/d].

STAVENHAGEN, Rodolfo. "Estratificação Social e Estrutura de Classes”, in: VELHO, Otávio Guilherme (Org.). Estrutura de classes e estratificação social. Rio de Janeiro: Zahar, 1977, pp. 133170.

\section{Obras de referência:}

Dicionário Brasileiro. Organizado por Francisco Fernandes, Celso Pedro Luft e F. Marques Guimarães. 56 a edição São Paulo: Editora Globo, 1996.

Dicionário de Política. Organizado por Norberto Bobbio, Nicola Matteucci e Gianfranco Pasquino, $5^{\text {a }}$ edição. Brasília: Editora da Universidade de Brasília, 2000.

Dicionário Histórico-Biográfico Brasileiro (1930-1983). Coordenação de Alzira Alves de Abreu et alii. Rio de Janeiro: Editora Forense-Universitára / FGV/CPDOC, 1984. 